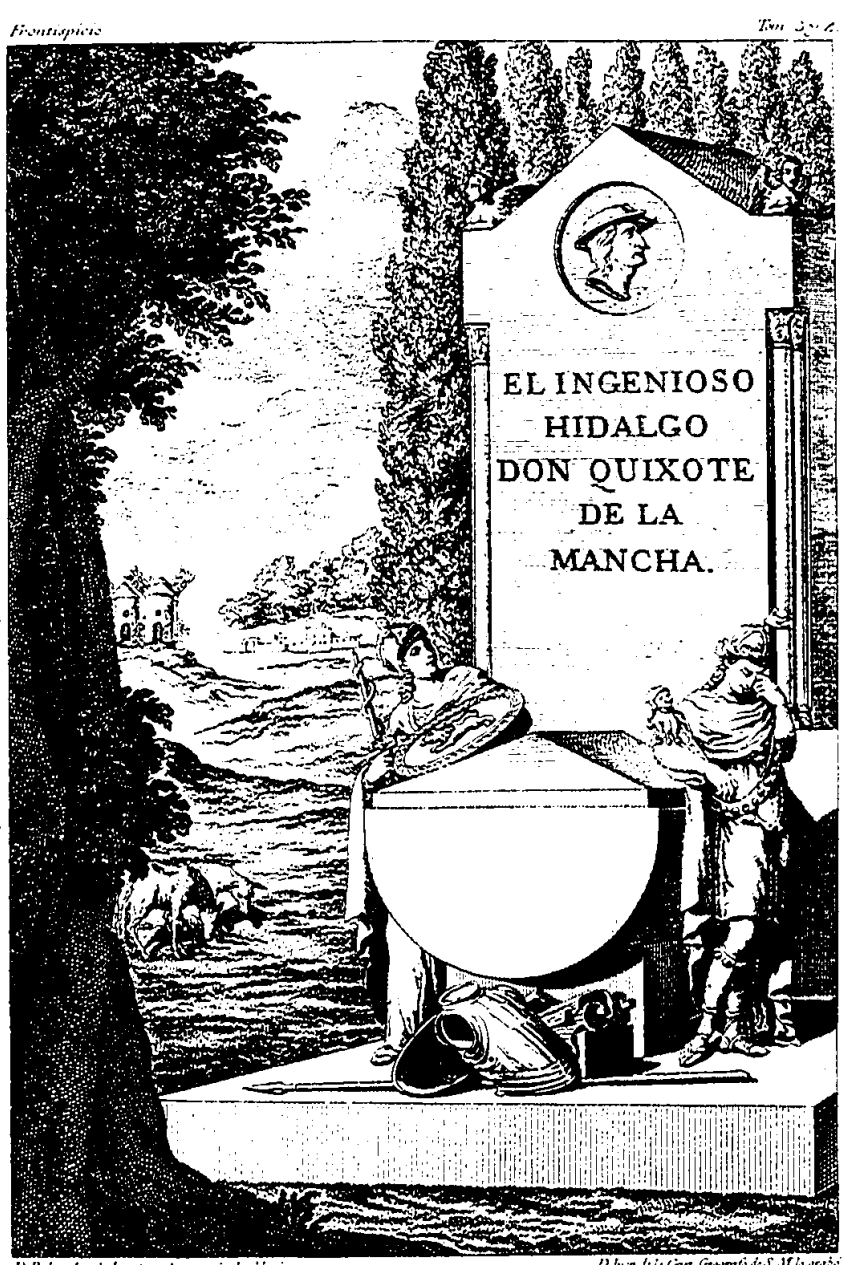




\section{EL INGENIOSO HIDALGO DON QUIXOTE \\ DE LA MANCHA}

CONIPUESTO

POR MIGUEL DE CERVÁNTES SAAVEDRA.

NUEVA EDICION

CORREGIDA

POR LA REAL ACADEMIA ESPAÑOLA.

PARTE SEGUNDA.

TOMO IV.

CON SUPERIOR PERMISO:

$$
\text { FN MADRID }
$$

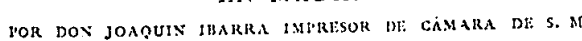

$Y$ DI: LA RLAL ACADEMIA.

$$
\text { MDCCLXxx. }
$$




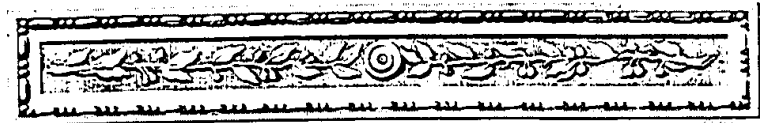

T A B L A

DE LOS CAPÍTULOS DE ESTE TOMO.

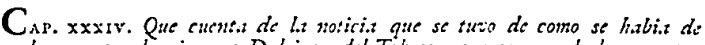

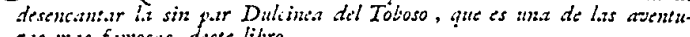

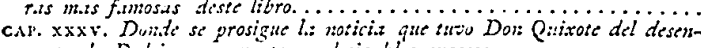

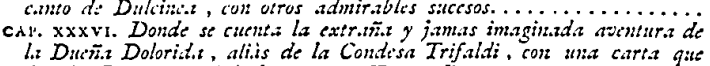

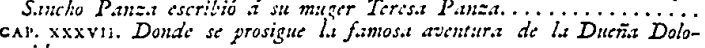

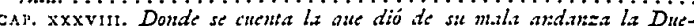

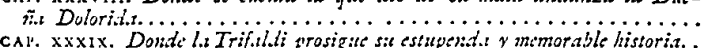

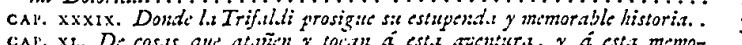

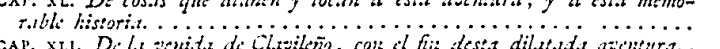

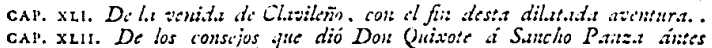

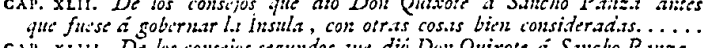

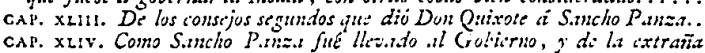

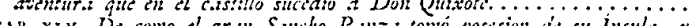

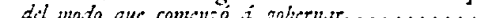

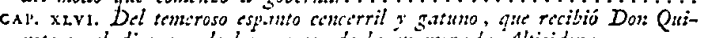

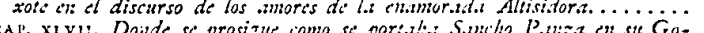

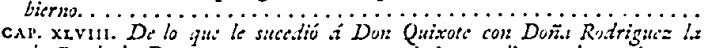

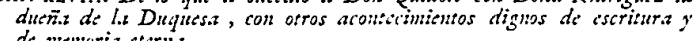

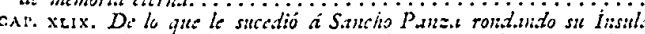

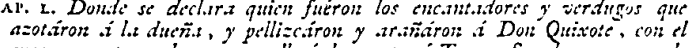

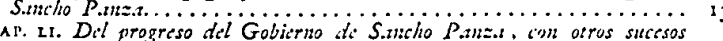

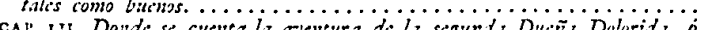

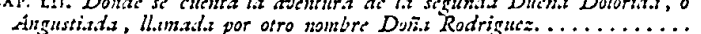




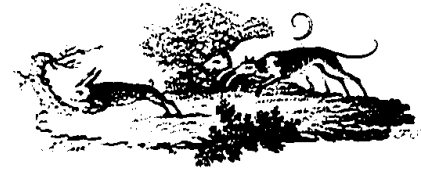

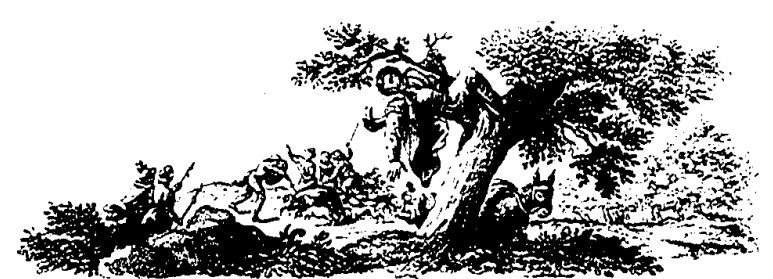

PARTE SEGUNDA

DEL INGENIOSO HIDALGO DON QUIXOTE

\section{DE LA MANCHA.}

\section{CAPITULO XXXIV.}

Oue cuenta de la noticia que se tuvo de como se habia de desencantar la sin par Dulcinea del Toboso, que es una de las aventuras mas famosas deste libro.

rande era el gusto que recebian el Duque

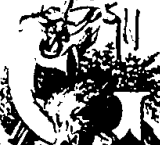

Q Duquesa de la conversacion de Don

Quixote, y de la de Sancho Panza, y con

firmándose en la intencion que tenian de N. hacerles algunas burlas que llevasen vislumbres $\mathrm{y}$ apariencias de aventuras, tomáron motivo de la que Don Quixote ya les habia contado de la cueva de Montesínos, para hacerle una que fuese famosa; pero de lo que mas la Duquesa se admiraba, era, que la simplicidad de Sancho fuese tanta, que hubiese venido á creer ser rom. IV. 

crdad infalible, que Dúl mesmo el encantador, y el cantada, habiendo sido el má habiendo dado órden embustero de aquel negocio : y asi habichdo dado orden a sus criados de todo lo que habian de hacer, de alli a seis dias le lleváron á caza de monteria con tanto aparato Rey méró á Don Quixote un vestido de Rey coronado. Dieronle a Derde de finísimo paño; pcmonte, $\mathrm{y}$ á Sancho otro verde de finsimo pano, pcro Don Quixote no se le quiso poner, diciendo, que otro dia habia de volver al duro exercicio de las armas, y ouc no podia llevar consigo guardaropas, ni reposterías. que no podia llevar con intencion de venSancho sí tomó el que le dicron, con intencion de venderle en la primera ocasion que pudiese. Llegado pues el esperado dia, armóse Don Quixote, vistióse Sancho, y encima de su rucio, que no le quiso dexar, aunque y encima de sll se metió entre la tropa de los monle daban un caballo, sé bizarramente aderezada y Don teros. Ia Duquesa salio bizanamente aderezada, y Don Quixote de puro cortes y comedido tomó la rienda de su palafren, aunque el Duque no queria consentirlo, $y$ su parren a altísimas finalnces los puestos, paranzas gente por y veredas, y repartida la gente por diferentes puestos, se comenzó la caza con grande estruendo, grita y vocería demancra que unos á otros no podian oirse, así por como por el son de las bocinas. A peóse la Duquesa, y con un agudo venablo en las manos se puso en un puesto por donde ella sabia que solian venir algunos jabalíes. Apeóse asimismo el Duque y Don Quirote y pusiéronse á sus lados: Sancho se puso detras de rodos, sin apearse del rucio á quien no osaba desamparar, porque no le sucedicse algun desman, y apćnas
PARTEII. CAPITUIO XXXIV: 3

habian sentado el pie, y puesto en ala con otros muchos criados suyos, quando acosado de los perros, y seguido de los cazadores, viéron que hácia ellos venia un desmesurado jabalí, cruxiendo dientes y colmillos, y arrojando espuma por la boca, y en viéndole, embrazando su escudo, y puesta mano á su espada, se adelantó á reccbirle Don Quixote : lo mesmo hizo el Duque con su venablo; pero á todos se adelantara la Duquesa, si el Duque no se lo es torbara. Solo Sancho en viendo al valiente animal, desamparó al rucio, y dió á correr quanto pudo, y procuran do subirse sobre una alta encina, no fué posible; ántes estando ya á la mitad della, asido de una rama, pugnando subir á la cima, fué tan corto de ventura, y tan desgraciado, que se desgajó la rama, $y$ al venir al suelo se quedó en el ayre asido de un gancho de la encina, sin poder llegar al suclo, y viéndose así, y que ei sayo verde se le rasgaba, y parcciéndole, que si aquel fiero animal alli llegaba le podia alcanzar, comenzó á dar tantos gritos, $\mathrm{y}$ á pedir socorro con tanto ahinco, que todos los que le oian, y no le veian, creyéron que estaba entre los dientes de alguna fiera. Finalmente el colmilludo jabalí quedó atravesado de las cuchillas de muchos venablos, que se le pusiéron delante, y volviendo la cabeza Don Quixote á los gritos de Sancho, que ya por ellos le habia conocido, vióle pendiente de la encina, y la cabeza abaxo, y ai rucio junto á él, que no le desamparó en su calamidad: $y$ dice Cide Hamete que pocas veces vió á Sancho Panza sin ver al rucio, ni al rucio sin ver á Sancho : tal era la amistad $y$ buena fe, que entre los dos se guardaban. Llegó Don Quixote, y descolgó á Sancho, el qual viéndose libre y en el suelo, miró lo desgarrado del sayo de monrom. Iv. 
DOY QUIXOTE DE IA MANCIIA

y pesóle en el alma, que pensó que tenia en el vesEn esto atravesáron al jabalí poderotido un mayorazómila, y cubriéndole con matas de roso sobre un acémila , mirto le lleváron como en señal mero y con ramas de mirto le llevandas de campaña de vitoriosos despojos á unas grandes tiendas de canpana que en mitad del bosque estaban puestas, donde haque en la mitas en órden, y la comida aderezada tan llíron las mesas en orden echaba bien dever en ella la suntuosa y grande, que se echabaien la daba. Sancho, grandeza y magnificencia de quien la roto vestido, dimostrando las llagas á la Duquesa de su roto vestio, dimostrando las llaga á de liebres, ó de paxarillos, seguxo: si esta caza fuera de verse en este extremo: yo no sé ro estuviera mi sayo de esperar á un animal, que si os que gusto se recibe de esperac a quitar la vida: yo me alcanza con un colmilln, os alcance

$$
\begin{aligned}
& \text { De los osos seas comido, } \\
& \text { como Fabila el nombrado. }
\end{aligned}
$$

Ese fué un Rey Godo, dixo Don Quixote, que yendo Ese es lo que yo a caza de monteria le comio un querria yo que los Príndigo, respondio Sancho, que no qu semejantes peligros cipes y los Reyes se pusiescn en se no le habia de á trueco de un gusto, que parece que no le habia de ser, pues consiste en matar á un animal que no ha cometido delito alguno. Ántes os engañais, Sancho, respondio el Duque porque el exercicio de la caza de monte es c el Duque, porque encesario para los Reyes y Príncimas conveniente, $y$ necesario para los Reyes y Principes, que otro alguno. La caza es una imugen de la gucrra, hay en ella estratagemas, astucias, insidias para venrer á su salvo al enemigo: padécense en ella frios grandísimos y calores intolerables: menoscábase el ocio y
PARTEIT. CAPÍTULO XXXIT.

5 el sueño, corrobóranse las fuerzas, agilítanse los micmbros del que la usa: y en resolucion, es exercicio que sc puede hacer sin perjuicio de nadie, y con gusto de muchos, y lo mejor que él tiene es, que no es para todos, como lo es el de los otros géneros de caza, excepto el de la volatería, que tambien es solo para Reyes y grandes Scñores. Así que, ó Sancho, mudad de opinion, y quando seais Gobernador ocupaos en la caza, y veréis como os vale un pan por ciento. Eso no, respondió Sancho, el buen Gobernador, la pierna quebrada y en casa : bueno seria que viniesen los negociantes á buscarle fatigados, y él estuviese en el monte holgándose, así cnhoramaia andaria el Gobierno. Mia fe, señor, la caza y los pasaticmpos mas han de ser para los holgazanes, que para los Gobernadores : en lo que yo pienso entretenerme, es en jugar al triunfo envidado las Pascuas, $\mathrm{y}$ á los bolos los domingos y fiestas, que esas cazas, ni cazos no dicen con mi condicion, ni hacen con $\mathrm{mi}$ conciencia. Plega á Dios, Sanclio, que así sea, porque del dicho al hecho hay gran trecho. Haya lo que hubiere, replicó Sancho, que al buen pagador no le duelen prendas, y mas vale al que Dios ayuda, que al que mucho madruga : y tripas llevan pies, que no pies á tripas, quicro decir, que si Dios me ayuda, y yo hago lo que debo con buena intencion, sin duda que gobernaré major que un gerifalte : no sino pónganme el dedo en la boca, y veran si aprieto, ó no. Maldito seas de Dios y de todos sus Santos, Sancho maldito, dixo Don Quixote, y quando será el dia, come otras muchas veces he dicho, donde yo te vea hablar sin refranes una razon corriente y concertada. Vuestras grandezas dexen á cste ton- 
to, scñores mios, que les molerá las almas, no solo pucstino entre dos mil refranes, traidos tan á tas entre dó, cé Dios á él la salud, sazon y tan a tiempo, quanto Los refranes de Sancho ó á mí, si los querria escuchar. Los son mas que los del Panza, dixo la Duquesa, pucsto que son ménos de cstimar, Comendador Griego, no por eso son ménos de e.timar, Comer la brevedad de las sentencias. De mi se decir, que por la brevedad de las sentencias. Due sean mejor traidos, me dan mas gusto que otros, Con estos y otros entretey con mas sazon acomodados. Con estonda al bosque, $y$ en nidos razonamientos saliéron de la tienda al bosque, y en requerir al gunas paranzas y puestos se les pasó cl dia, $y$ sc requen a tan clara, ni tan sesga, como la les vino la noche, y ne era en la mitad del verano; sazon del ticmpo pechia, que era en la mitad consigo, ayudó pero un cicreo cluro escuro, que truxo consico, ayudo mucho á la intencion de los Duques, $y$ asi como conenzó í anochecer, un poco mas adelante del crepúsculo, zó lt ancher el bosque por todas quatro á deshora pareció que todo écon por aquí y por allí, por partes se ardia, y luego se oycron por aqui y por all, por acá y por acullid infinitas cornetas, $y$ otros instrumentos de guerra como de muchas tropas de caballería, que por gue La luz del fuego, el son de los béliel bosque pasan. La los cos instrumentos casi cegaron y aronar los que en $\mathrm{c}$ oidos de los circunstantes, $y$ aun de todos los que en el bosque estaban. Luego se oyeron infinitos lelilies al uso de Moros, quando entran en las batallas : sonar on tromde petas. clatic faros, casi todos á un tienpo, tan conedor sin él al son sa, que no tuviera sentido el que no quedara sin él al son confuso de tantos instrumentos. Pasmose el Duque, suspendióse la Duquesa, admiróse Don Quixote, tembló Sancho Panza y finalmente, aun hasta los mesmos sa-
PARTEII. CAPITUIO XXXIV.

bidores de la causa se espantáron. Con el remor les cogió el silencio, $y$ un postillon que en trage de demonio les pasó por delante, tocando en vez de corneta, un hueco y desmesurado cuerno, que un ronco y espantoso son despedia. Ola, hermano correo, dixo el Duque aquien sois? : adonde vais? ¿y que gente de guerra es la que por este bosque parece que atraviesa? A lo que respondió el correo con voz horrísona y desenfadada: yo soy cl diablo, voy á buscar á Don Quixote de la Mancha, la gente que por aquí viene son seis tropas de encantadores, que sobre un carro triunfante traen á la sin par Dulcinea del Toboso : encantada viene con el gallardo Frances Montesínos á dar órden á Don Quixote de como ha de ser desencantada la tal Señora. Si vos fuérades diablo como decis, y como vuestra figura muestra, ya hubiérades conocido al tal caballero Don Quixote de la Mancha, pues le teneis delante. En Dios y en mi conciencia, respondió el diablo, que no miraba en ello, porque traigo en tantas cosas divertidos los pensamientos, que de la principal á que venia se me olvidaba. Sin duda, dixo Sancho, que este demonio debe de ser hombre de bien y buen christiano, porque á no serlo, no jurara en Dios y en mi conciencia : ahora yo tengo para mí, que aun en el mesmo infierno debe de haber buena gente. Lucgo el demonio, sin apearse, encaminando la vista á Don Quixote, dixo : á ti el Caballero de los Leones (que entre las garras de ellos te vea yo) me envia el desgraciado, pero valiente caballero Montesínos, mandándome, que de su parte te diga que le esperes en el mismo lugar que te topare, á causa que trae consigo á la que llaman Dulcinea del Toboso, con 
8

DON QUIXOTE DE IA MANCHA

orden de darte la que es menester para desencantarla, y orden de darte la que mi venida, no ha de ser mas mi espor no ser para mas mi vo queden contigo, y los Ántada : los demonios como yo queden diciendo esto tocó geles bucnos con estos senoré y en diciendo fuese in el desaforado cuerno, $y$ volvió las espalda, y fuese sin esperar respuesta de ninguno. Renovóse la admiracion en todos, especialmente en Suncho y en Don Quixote : en todos, especialmente é Sancho en ver que a despecho de la verdixote, por no potuviese encantada Dulcinea: en Don Quixote, por no der asegurarse, si era verdad, ó no lo que le habia pasado en la cucva de Montesínos, y estando elevado en estos en la cucva de Duque le dixo: ¿ piensa ruesa merced pensamientos es aquí esperar, señor Don Quixote? esperaré intrépido y fuerte, si me viniese a cmbestir todo cl infierno. Pues si yo veo otro diablo, y oigo otro cuerno como el pasado, así esperaré yo aquí, como en Flándes, como el par mas la noche, y comendixo Sancho. En esto se caró mas la bosque, bien así záron á discurrir muchas luces por el bosque, bien aś como discurren por el cielo las exhalaciones secas de la tierra, que parceen á nuestra vista estrellas que corren. Oyóse quimismo un espantoso ruido, al modo de aquel Oyose asimismo un esalos macizas gue suelen traer los que se calsa de las ruedas macizas que suelen uera los carros de bueyes, de cuyo chirrio aspero, y continuado se dice, que huyen los lobos, y los osos, si los hay por donde pasan. Añadióse á toda esta tempestad otra que las aumentó todas, que fué, que parecia verdaderaque las aumento todos, que fuć, que pare se estabon danmente que á las quatro partes del bosque se estaban dando á un mismo tiempo quatro reencuentros, ó batallas, porque allí sonaba el duro estruendo de espantosa arti1leria, acullí se disparaban infinitas escopetas, cerca casi sonaban las voces de los combatientes, léjos se rei-
PARTE II. CAPITUI.O $\mathrm{x} \times \mathrm{xIV}$

tcraban los lelilíes agarenos. Finalmente las cornetas, los cuernos, las bocinas, los clarines, las trompetas, los tambores, la artillería, los arcabuces, y sobre todo el temeroso ruido de los carros formaban todos juntos un son tan confuso, $\mathrm{y}$ tan horrendo, que fué menester que Don Quixote se valiese de todo su corazon para sufrirle; pero el de Sancho vino á tierra, y dió con él desmayado en las faldas de la Duquesa, la qual le recibió en ellas, y á gran priesa mandó que le cchasen agua en el rostro. Hízose así, y él volvió en su actierdo á tiempo que ya un carro de las rechinantes ruedas llegaba á aquel puesto. Tirábanle quatro perezosos bueyes, todos cubiertos de parnmentos negros : cn cada cuerno traian atada, y encendida una grande hacha de cera, y encima del carro venia hecho un asiento alto, sobre el qual venia sentacio un venerable viejo con una barba mas blanca que la mesma nieve, $y$ tan lucnga, que le pasaba de la cintura : su vestidura era una ropa larga de negro bocací, que por venir el carro ileno de infinitas luces, se podia bien divisar y discernir todo lo que en él venia. Guiábanle dos feos demonios, vestidos del mesmo bocací, con tan fcos rostros, que Sancho habiéndolos visto una vez, cerró los ojos per no verlos otra. Llegando pues cl carro á igualar al pucsto, se levantó de su alto asiento cl riejo venerable, y puesto en pic, dando una gran voz, dixo: yo soy cl sabio Lirgandeo, y pasó el carro adelante, sin hablar mas palabra. Tras este pasó otro carro de la misma mancra con otro vicjo entronizado, el qual haciendo que el carro se detuviese, con voz no ménos grave que cl otro, dixo: yo soy el sabio Alquife, el grande amigo de Urganda la desconocida, y pasó adelante. Lueron. Iv.
$B$ 
o por el mismo continente llegó otro carro; pero el go por el mismdo en el trono, no era viejo como los deque venia sentado en clusto, $y$ de mala catadura, el qual mas, sino hombron robusto, al llegar, levantándose en pie, como los otros, dixo con voz mas ronca y mas endiablada. yo soy Arcalaus el con voz mas ronca y mortal de Amadis de Gaula y de encantador, enemigo mor á de Amte. Poco desviados de toda su parentela, y pasó adclante. Pó cl enfadoso ruiallí hicieron alto estos tres carros, y cesó cl enfadoso ruido de sus ruedas, y luego no se oyó otro ruido, sino do de sus ruedas y concertada música formado, con un son de una saló $y$ lo tuvo á buena señal, $y$ así que Sancho se alegro, yi un paso se dixo á la Duquesa, de quien un panto, na un paso se apartaba: señora, donde hay música, no puede hader cosa mala. Tampoco donde hay luces y claridad, respondió la Duquesa. A lo que replicó Sancho: luz da el fuedio la Duquad las hogueras, como lo vemos en las que go, y claridad las hogueras, como nos abrasasen; pero la nos cercan, y bien podria ser que nos abrasasen, pero a música sicmpre es indicio de regocijos $\mathrm{y}$ de fiestas. Ello dirá, dixo Don Quixote, que todo lo escuchaba, y dixo bien como se muestrs en el capítulo siguiente.

\section{CAPÍTULO XXXV.}

Donde se prosigue la noticia que tuvo Don Ouixote del descanto de Dulcinea, con otros admirables sucesos.

A 1 compas de la agradable música, viéron que háA carro de los que llaman triunfales, ticia ellos seis mulas pardas, encubertadas empero de lienzo blanco, y sobre cada una venia un diciplinante de luz, blanco, y sobre ca ha venia un una hacha de cera grande encendida en la mano. Era el carro dos veces, y aun
PARTEII. CAPATULO XXXY.

tres mayor que los pasados, y los lados y encima dél ocupaban otros doce diciplinantes albos como la nieve, todos con sus hachas encendidas, vista que admiraba, y espantaba juntamente, $y$ en un levantado trono venia sentada una Ninfa vestida de mil velos de tela de plara, brillando por todos ellos infinitas hojas de argentería de oro, que la hacian, si no rica, aloménos vistosamente vestida : traia el rostro cubierto con un trasparente y delicailo cendal, de modo, que sin impedirlo sus lizos por entre ellos se descubria un hermosísimo rostro de doncclla, y las muchas luces daban lugar para distinguir la belleza y los años, que al parecer no llegaban á veinte, ni baxaban de diez y siete: junto á ella venia una figura vestica je una ropa de las que llaman rozagantes, hasta los pies, cubierta la cabeza con un velo negro; pero al punto que llegó el carro á estar frente á frente de los $\mathrm{Dur}$ ques y de Don Quixote, cesó la música de lús chirimías, y luego la de las arpas y la ides, que en el carro sonaban, y levantándose en pie la figura de la ropa, la apartó á cntrámbos lados, y quitándose el velo del rostro, descubrió patentemente ser la mesma figura de la muerte, descarnada y fea, de que Don Quixote recibió pesadumbre, $y$ Sancho miedo, y los Duques hiciéron algun sentimiento temeroso. Alzada y puesta en pie esta muerte viva, con voz algo dormida, $y$ con lengua no muy despierta, comenzó á decir desta manera:

Yo soy Merlin, aquel que las historias

Dicen que tuve por mi padre al diablo,

(Mentira autorizada de los tiempos)

Principe de la Mágica, y Monarca 

$Y$ archivo de la ciencia zoroástrica, Emulo á las edades y á los siglos, Oue solapar pretenden las hazañas $\widehat{D}_{e}$ los andantes bravos caballeros, A quien yo tuve y tengo gran carino.

$Y$ puesto que es de los encantadores,

De los magos ó mágicos contino

Dura la condicion, áspera y fuerte,

La mia es tierna, blanda y amorosa,

$Y$ amiga de hacer bien á todas gentes.

En las cabernas lobregas de Dite,

Domde estaba mi alma ontmitonida

En formar ciertos rombos $y$ carácteres,

Llegó la voz doliente de la bella

$Y$ sin par Dulcinea dil Toboso.

Supe su encantamento y su desoracia.

$Y$ su trasformacion de gentil dama

En rística aldeana: condolime,

$Y$ encerrando mi espiritu en el hueco

Desta espantosa y fiera notomia,

Despues de haber revuelto cien mil libros

Desta mi ciencia endemoniada y torpe,

$V$ engo á dar el remedio gue conviene

A tamaño dolor, á mal tamaño.

$O$ tí , gioriaz $y$ honor de quantos visten

Las túnicas de acero y de diamante, Luz y farol, sendero, norte y guia De aquellos que dexando el torpe sueño $Y$ las ociosas plumas, se acomodan A usar el exercicio intolerablo

De las sangrientas, y pesadas armas:
PARTEII. CAPIIULO XXXV.

A ti digo, ó varon, como se debe

Por jamas alabado, á ti valiente

Juntamente, y discreto Don Quixote,

De la Mancha esplendor, de España estrella,

Oue para recobrar su estado primo

La sin par Dulcinea del Toboso,

Es menester que Sancho tu escudero

Sie dé tras mil azotes y trecientos

En ambas sus valientes posaderas,

Al ayne descubientas, $y$ de modo

Qui le escuezan, le amarguen y le enfaden.

$\hat{Y}$ en esto se resuelven todos quantos

De su desgracia han sido los autores.

$Y$ á esto es mi venida, mis señores.

Toto á tal, dixo á esta sazon Sancho, no digo yo tres mil azotes; pero así me daré yo tres, como tres puñalaJas Vilarc el diablo por modo de desencantar, yo no sé que ticnen que ver mis posas' con los encantos. Par Dios que si el seńor Merlin no ha hallado otra manera como desencantar á la Señora Dulcinca del Toboso, encantada se podrá ir á la sepultura. Tomaros he yo, dixo Don Quixote, Don rillano, harto de ajos, y amarraros he á un árbol desnudo como vuestra madre os parió, $y$ no digo yo tres mil y trecientos, sino seis mil y seiscientos azotes os daré, tan bien pegados, que no se os caigan á tres mil y trecientos tirones, y no me repliqueis palabra, que os arrancaré el alma. Oyendo lo qual Merlin dixo : no ha de ser así, porque los azotes que ha de recebir el buen Sancho, han de ser por su voluntad, y no por fucrza, $y$ en el ticmpo que el quisiere, que no 
14

DON QUTXOTE DE IA MANCIH

po término señalado; pero permítescle, que si él quisiere redimir su vexacion por dé agena mano, aunque miento, puede dexar que se los dé agena mi pesada, ni por sea algo pesada. Ni agena, ní no me lia de tocar al guna pesar, replicó Sancho, á mi no nicia Dulcinca del Tomano. :Parí yo por ventura a la Scnora Dulcinca del To mano. Par yo paguen mis posas lo que pecaron sus ojos boso, para que pasu qú que es parte suya, pues la llama El seńor mi amo si que clma, sustento y arrimo suyo, cada paso mi vida, mi al ella, y hacer todas las dise puede $y$ debe azotar por deranto; pcro azotarme limencias necesarias para su descncanto; pero zazor ligencias nuncio. Apénas acabó de decir esto Sancho, yo? abernuncióndose en pie la argentada Ninfa, que junquando levantandosen venia, quitándose el sutil velo to al espiritu de Merió val, que á todos pareció mas que del rostro, le descubrió tal, que á to enfado varonil, demiadamente hermoso, y con un descho dem y con una vaza dixo : ó mal aventurado cscudero, con Sancho Panza, dino: de alcornoque, de entrańas guialma de cántaro, corazon de alcornaran, ladron, desuella jeńas y apedernaladas, si te mandar to lad suelo, si te caras, que te arrojaras de una alta torre al suclo, si te pide cnemigo del género humano, que te comicras pidicran, chas des de una doccha de sapos, dé que mataras á tu muger, y a bras, si te persuadicran a que mado alfange, no fuetus hijos con algun truculento y agulo alfonge, no fuivo; ra maravilia que te mostraras melindroso y csquivo; pero hacer caso de tres mil y trecientos azotes, que no pero hacer caso doctrina, por ruin que sea, que no se los hay niño de la doctras enlleve cada mes, admira, adarva, espan a todas las todos trañas piadosas de los que lo escuchan, el discurso del tiem-
PARTEII. CAPITULO XXXV.

po. Pon, ó miserable y endurecido animal, pon, digo, esos tus ojos de machuelo espantadizo en las niñas destos mios, comparados á rutilantes estrellas, y veráslos llorar hilo á hilo, y madexa á madexa, haciendo surcos, carreras $y$ sendas por los hermosos campos de mis mexillas. Mućvatc, socarron y mal intencionado monstro , que la cdad tan florida mia, que aun se está todavía en el diez y....de los ańos, pues tengo diez y nueve, y no llego á veinte, se consume y marchita debaxo de la corteza de una rústica labradora, y si ahora no lo parezco, es merced ${ }^{2}$ particular que me ha hecho cl señor Merlin, que cstá presente, solo porque te enternezca mi belleza, que las lígrimas de una afligida hermosura vuelven en algodon los riscos, y los tigres en ovejas. Date, date en esas curnazas, bestion indómito, y saca de haron ese brio, que á solo comer y mas comer te inclina, $y$ pon en libertad la lisura de mis carnes, la mansedumbre de mi condicion y la belleza de mi faz: y si por mí no quieres ablandarte, ni reducirte á algun razonable término, hazlo por ese pobre caballero, que á tu lado ticnes, por tu amo digo, de quien estoy viendo el alma, que la ticne atravesada en la garganta, no diez dedos de los labios, que no espera sino tu rígida, ó blanda respuesta, ó para salirse por la boca, ó para volverse al estómago.

Tentóse, oyendo esto, la garganta Don Quixote, y dixo, volviéndose al Duque : por Dios, señor, que Dulcinea ha dicho la verdad, que aquí tengo cl alma atravesada en la garganta, como una nuez de ballesta. ¿Que decis vos á esto, Sancho? preguntó la Duquesa. Digo, senora, respondió Sancho, lo que tengo dicho, que de los azores abernuncio. Abrenuncio habeis de decir, San- 
Domo decis, dixo el Duque. D cho, y no comodió Sancho, que no estoy agora para migrandeza, respondio San letras mas á ménos, porque me tar en sotilezas, ni en letras mas au me han de dar, tienen tan turbado estos azotes, que digo, ni lo que me tengo de dar, que no se lo que me Señora mi Señome hago ; pero querria yo saber de la Sende aprendio el mora Doña Dulcinea del Toboso, á ondirme que me abra do de rogar que tiene. viene a pedirme que me abra do de rogá quetes, y llámame alma de cántaro y beslas carnes a azo malos nombres que tion indomito, con tha ventura son mis carnes de broncl diablo los sufra. épor ventura sonencante, ó no ¿que cc? ¿á vame á mí algo en que se desencante, ó no qu canasta de ropa blanca, de camisas, de tocadores y de cansunes, aunque no los gasto, trae dela escarpines, aunque no viruperio y otro, sabiendo aque ta ablandarme, sino un lí, que un asno cargado de oro strefran que dicen por aht, que un asno cádivas quebrantan be ligero por una montana, y que distion perias, y á Dios rogando, $y$ con el mazo dando, y que mas va un toma, que dos te daré? Pues el señor mi amo, mas vale un toma, que da mano por el cerro, y halagarque habia de tra me hicicse de lana y de algodon carme, para que yo me licicse de dado, dice que si me coge, me amarrara desnudo a un árbol, y me doblará la parada de los azotes : $y$ habian de considerar estos lastimados señores, que no solamende considerar estos lastim un cscudero, sino un Gobernate piden que se azo un abe con guindas. Aprendan, dor, como quien dice, bebe con guindas. Aprcndan, aprendan mucho de cnhoramala á saber rogar, y á sabe pedir, $r$ á tener crianza, que no son todos los tiempos unos, están los hombres siempre de un buen humor. Estoy jo a ora reventando de pena por ver mi sayo verde roto, y vienen á pedirme que me azote de mi volun- tad, cstando clla tan agena dello, como de volverme Cacique. Pues en verdad, amigo Sancho, dixo el Duque, que si no os ablandais mas que una breva madura, que no habeis de empunar el Gobierno. Bueno seria que yo enviase á mis insulanos un Gobernador cruel, de entranias pedernalinas, que no se doblega á las lágrimas de las anligidas doncellas, ni á los ruegos de discretos, imperiosos, y antiguos encantadores y sabios. En resolucion, Sancho, ó vos habcis de ser azotado, ó os han de azotar, ó no habcis de ser Gobernador. Señor, respondió Sancho, ¿no se me darian dos dias de término para pensar lo que me está mejor? No, en ninguna manera, dixo Merlin: aquí en este instante y en este lugar ha de quedar asentado lo que ha de ser deste negocio: ó Dulcinea volverá á la cueva de Montesínos, y á su prístino estado de labradora, ó ya en el ser que está, será llevada á los Eliseos campos, donde estarí esperando se cumpla el número del vápulo. Ea, buen Sancho, dixo la Duquesa, buen únimo y buena correspondencia al pan que habeis comido del scñor Don Quixote , á quien todos debemos servir y agradar por su buena condicion y por sus altas caballerías. Dad el sí, hijo, desta azotayna, y váyase el diablo para diablo, y el temor para mezquino, que un buen corazon quebranta mala ventura, como vos bien sabcis. Á estas razones respondió con estas disparatadas Sancho, que hablando con Merlin le preguntó : dígame vuesa merced, señor Merlin : quando llegó aquí el diablo correo, dió á mi amo un recado del señor Montesínos, mandándole de su parte, que le esperase aquí, porque venia á dar orden de que la Señora Doña Dulcinea del Toboso se desencantase, y hasta agora no hemos visto á Montesíтом. Iv. 
nos, ni á sus seméjas. Á lo qual respondió Merlin : el diablo, amigo Sancho, es un ignorante, $y$ un grandísimo bellaco, yo le envie en busca de vuestro amo; pero no con recado de Montesínos, sino mio, porque Montesínos se está en su cueva, entendiendo, ó por mejor decir esperando su desencanto, que aun le falta la cola por desollar: si os debe algo, ó teneis alguna cosa que negociar con él, yo os lo traeré, y pondré donde vos mas quisiéredes: y por agora acabad de dar el sí desta diciplina, y creedme, que os será de mucho provccho, así para el alma, como para el cuerpo: para el alma, por la caridad con que la haréis, para el cucrpo, porque yo sé que sois de complexîon sanguinea, y no os podrá hacer daño sacaros un poco de sangre. Muchos médicos hay en el mundo : hasta los encantadores son médicos, replicó Sancho; pero pues todos me lo dicen, aunque yo no me lo veo, digo que soy contento de darme los tres mil y trecientos azotes, $\mathrm{con}^{3}$ condicion, que me los tengo de dar cada y quando que yo quisiere, sin que se me ponga tasa en los dias, ni en el tiempo, y yo procuraré salir de la deuda lo mas presto que sea posible, porque goce el mundo de la hermosura ${ }^{4}$ de la Scñora Dońa Dulcinea del Toboso, pues segun parece, al reves de lo que yo pensaba, en efecto es hermosa. Ha de ser tambien condicion, que no he de estar obligado á sacarme sangre con la diciplina, y que si algunos azotes fueren de mosqueo, se me han de tomar en cuenta. Iten, que si me errare en el número, el señor Merlin, pues lo sabe todo, ha de tener cuidado de contarlos, y de avisarme los que me faltan, ó los que me sobran. De las sobras no habrá que avisar, respondió Merlin, porque lle- gando al cabal número, luego quedarí de improviso desencantada la Señora Dulcinea, y vendrá á buscar, como agradecida, al buen Sancho, y á darle gracias y aun premios por la buena obra. Así que no hay de gue tener escrúpulo de las sobras, ni de las faltas, ni el Cielo permita, que yo engañe á nadie, aunque sea en un pelo de la cabcza. Ea pues, á la mano de Dios, dixo Sancho, yo consiento en mi mala ventura, digo que yo accpto la penitencia con las condiciones apuntadas. A pé nus dixo estas riltimas palabras Sancho, quando volvió á sonar la música de las chirimías, y se volviéron á disparar infinitos arcabuces, $y$ Don Quixote se colgó del cuello de Sancho, dándole mil besos en la frente y en las mexillas. La Duquesa, y el Duque, y todos los circunstantes diéron muestras de haber recibido grandísimo contento, $y$ el carro comenzó á caminar, y al pasar la hermosa Dulcinea inclinó la cabeza á los Duques, y hizo una gran rererencia á Sancho: y ya en esto se venia á mas andar el alba alegre y risucña: las florecillas de los campos se descollaban y erguian, $y$ los líquidos cristales de los arroyuelos, murmurando por entre blancas, y pardas guijas, iban á dar tributo á los rios que los esperaban : I tierra alegre, el cielo claro, el ayre limpio, la luz serena, cada uno por sí, y todos juntos daban manifiestas señales, que el dia que al aurora venia pisando las faldas, habia de ser sereno y claro. $Y$ satisfechos los Duques de la caza, y de haber conseguido su intencion tan discreta y felicemente, se volviéron á su castillo, con prosupuesto de segundar en sus burlas, que para ellos no habia véras que mas gusto les diesen.

TOM. IV. 


\section{CAPITULO XXXVI.}

Donde se cuenta la extrania y jamas imaginada aventura de la Dueña Dolorida, alias de la Condesa Trifaldi, con una carta que Sancho Panza escribio á su muger Teresa Paqza.

Tenia un mayordomo el Duque de muy burlesco y desenfadado ingenio, el qual hizo la figura de Merlin, y acomodó todo el aparato de la aventura pasada, compuso los versos, y hizo que un page hiciese á Dulcinea. Finalmente con intervencion de sus Señorcs, ordenó otra del mas gracioso y extraño artificio que puede imaginarse. Preguntó la Duquesa á Sanclio otro dia, si habia comenzado la tarea de la penitencia, que habia de hacer por el desencanto de Dulcinca. Dixo que sí, y que aquella noche se habia dado cinco azotes. Preguntóle la Duquesa, que con que se los habia dado. Respondió, que con la mano. Eso, replicó la Duquesa, mas es darse de palmadas, que de azotes : yo tengo para mí, que el sabio Merlin no estará contento con tanta blandura, menester será que el buen Sancho haga alguna diciplina de abrojos, ó de las de caneloncs, que se dexen sentir, porque la jetra con sangre entra, y no se ha de dar tan barata la libertad de una tan gran Señora, como lo es Dul cinea, por tan poco precio. $\Lambda$ lo que respondió Sancho: deme Vuestra Señoria alguna diciplina, ó ramal conveniente, que yo me daré con él, como no me duela demasiado, porque hago saber á vuesa merced, que aunque soy rústico, mis carnes tienen mas de algodon, que de esparto, y no será bien que yo me descrie por el pro- vecho ageno. Sea en buena hora, respondió la Duquesa, yo os daré mañana una diciplina, que os venga muy al justo, $y$ se acomode con la ternura de ruestras carnes, como si fueran sus hermanas propias. Á lo que dixo Sancho: sepa Vuestra Alteza, señora mia de mi ánima que yo tengo escrita una carta á mi muger Teresa Pan$z a$, dándole cuenta de todo lo que me ha sucedido despucs que me aparté della : aquí la tengo en el seno que no le falta mas de ponerle cl sobre cscrito: querria que vuestra discrecion la leyese, porque me parece que va conforme á lo de Gobernador, digo al modo que deben de escribir los Gobernadores. ¿Y quien la notó $\vdots$ precuntó la Duquesa. Quien la habia de notar sino yo, pecidor de mí, respondió Sancho. ¿Y escribístesla ros? dixo la Duquesa. Ni por pienso, respondió Sancho, porque yo no sé lecr, ni escribir, pucsto que sé firmar. Veámosla, dixo la Duquesa, que á buen seguro, que vos mostreis en clla la calidad, y suficiencia de vuestro ingenio. Sacó Sancho una carta abierta del seno, y tomándola la Duquesa, vió que decia desta mancra:

\section{CARTA DE SANCHO PANZA A TERESA P-ANZA SE MUGER}

$S_{i}$ Gebios azotes me daban, bien calallivo me iba: si bieno me tengo, bnenos a ates me cuesta. Esto no lo entenderás tii, Teresa mia, por ahora, otraz rez lo sabrás. Has de saber, Teresa, que tengo determinado que andes en coche, que es lo que hace al caso, porque todo otro andar, es andar á gatas. Muger do un Gobernador eres, mira si to roerí nadio los a zu cajos. Ahi te envio un vestido verde de cazador, qui 
me dió mi señora la Duquesa, acomódale en modo que sirva de saja y cuurpos á muestia hija. Don Quixote mi amo, segun he oido decir en esta tierra, es un loco cucrito, y un mentecato gracioso, y que yo no le voy en zaga. Hemos estado on la cueva de Montesinos, y el sabio Merlin ha echado mano de mi para el desencanto de Dulcinea del Toboso, que por allá se llama Aldonza Lorenzo. Con tres mil y trecientos azotes ménos cinco, que me he de dar, quedará desencantada como la madre que la parió. No dirás desto nada á nadie, porque pon lo tujo en concejo, y unos dirán que es blanco, $y$ otros que es negro. De aquí á pocos dias me partire al Gobivrno, adonde voy con grandisimo deseo de hacer dineros, porque me han dicho que todos los Gobernadores muevos wan con este mesmo deseo: tomarilo el pulso, y avisaréte, si has de venir á estar conmigo, ó no. El rucio está bueno, y se te encomienda mucho ,y no le pienso dexar, aungue me llevaran á ser Gran Turco. La Duquesa mi seriora te besa mil veces las manos, vucituele el retorno con dos mil, que no hay cosa que mónos cueste, ni valga mas barata, segun dice mi amo, que los bucnos comedimientos. No ha sido Dios servido de depararme otra maleta con otros cien escudos, como la de márras; pero no te dé pena, Terisa mia, que en salvo está el que repica, y todo saldrí en la colada del Gobicmo, sino que me ha dado gran pena, que me dicen, que si una vez le pruebo, que me tengo de comer las manos tras él, y si as fuese, no me costaria muy barato, aunque los estropeados y mancos ya se tienen su Calongia en la limosna que pidcn : asi que por una via, ó por otra

TARTEII. CAPITULO XXXVI.

til has de ser rica, $y$ de buena ventura. Dios te la dé, como puede, y á mi me guarde para servirte. Deste castillo a 20 de Julio de I $\sigma_{14}$.

\section{Tu marido el Gobernador} Sancho Panza.

En acabando la Duquesa de leer la carta, dixo á Sancho: en dos cosas anda un poco descaminado el buen Go. bernador: la una, en decir, ó dar á entender, que este Gobierno se le han dado por los azotes que se ha de dar, sabiendo él, que no lo puede negar, que quando el Duque mi señor se lc prometió, no se soñaba haber azotes en cl mundo: la otra es, que se muestra en ella muy codicioso, y no querria que orégano fuese, porque la codicia rompe el saco, y el Gobernador codicioso hace la justicia desgobernada. Yo no lo digo por tanto, señora, respondió Sancho, y si á vuesa merced le parece que la tal carta no va como ha de ir, no hay sino rasgarla, y hacer otra nueva, y podria ser que fuese peor, si me lo dexan á mi caletre. No, no, replicó la Duquesa, buena estás esta, y quiero que el Duque la vea. Con esto se fuéron á un jardin, donde habian de comer aquel dia. Mostró la Duquesa la carta de Sancho al Duque, de que recibió grandísimo contento. Comiéron, y despues de alzados los manteles, y despues de haberse entretenido un buen espacio con la sabrosa conversacion de Sancho, á deshora se oyó el son tristísimo de un pífaro, $y$ el de un ronco y destemplado tambor. Todos mostráron alborotarse con la confusa, marcial y triste armonía, especialmente Don Quixote, que no cabia en su 
24

DON QUTSOIE DE IA MANCHA

asiento de puro alborotado: de Sancho no hay que decir, sino que el miedo le llevó á su acostumbrado refugio, que era el lado, ó faldas de la Duquesa, porque rea Y verdaderamente el son que se escuchaba era tristísimo Y malencólico. Y estando todos así suspensos, viéron entrar por el jardin adelante dos hombres vestidos de luto, tan luengo $y$ tendido, que les arrastraba por el sue10: estos venian tocando dos grandes tambores, asimismo cubiertos de negro. Á su lado venia el pífaro negro 5 pizmiento como los demas. Seguia á los tres un personage de cuerpo agigantado, amantado, no que vestido con una negrísima loba, cura falda era asimismo desaforada de grande. Por encima de la loba le ceñia $y$ atravesaba un ancho tahalí, tambien negro, de quien pendia un desmesurado alfange de guarniciones y vayna negra. Tenia cubierto el rostro con un trasparente velo negro, por quien se entreparecia una longísima barba, blanca como la nieve. Movia el paso al son de los rambores, con mucha gravedad y reposo. En fin, su gran deza, su contoneo, su negrura, $y$ su acompañamiento pudiera $y$ pudo suspender á todos aquellos que sin conocerle le miráron. Llegó pues con el espacio y prosopopeya referida á hincarse de rodillas ante el Duque, que en pie con los demas que allí estaban le atendia. Pero el Duque en ninguna manera le consintió hablar, hasta que se levantase. Hízolo así el espantajo prodigioso, y puesto en pie, alzó el antifaz del rostro, $y$ hizo patente la mas horrenda, la mas larga, la mas blanca, y mas poblada barba que hasta entónces humanos ojos habian visto, $y$ luego desencaxó $y$ arrancó del ancho $r$ dilatado pecho una voz grave y sonora, y poniendo los ojos en el
PARTE II. CAPITUIO XXXVT.

Duque, dixo: Altísimo y Poderoso Señor, á mí me llaman Trifaldin el de la barba blanca, soy escudero de Ia Condesa Trifaldi, por otro nombre llamada la Dueña Do lorida, de parte de la qual traigo á vuestra grandeza una cmbaxada, y es, que la vuestra magnificencia sea servi da de darla facultad y licencia para entrar á decirle su cuita, que es una de las mas nuevas, y mas admirables, que cl mas cuitado pensamiento del orbe pueda haber pensado: y primero quiere saber si está en este vuestro castillo cl valeroso, y jamas vencido caballero Don Quixote de la Mancha, en cuya busca viene, á pie, y sin desayunarse desde el Reyno de Candaya, hasta este vuestro Estado, cosa que se puede y debe tener á milagro, ó á fuerza de encantamento : clla queda á la puerta desta fortaleza, ó casa de campo, y no aguarda para entrar, sino viestro bencplácito. Dixe. $Y$ tosió luego, manoseóse la barba de arriba abaxo con entrámbas manos, y con mucho sosiego estuvo arendiendo la respuesta del Duque, que fué: Ya, buen escudero Trifaldin de la blanca barba, ha muchos dias que tenemos noticia de la desgracia de mi señora la Condesa Trifaldi, á quien los encantadores la hacen llamar la Dueńa Dolorida : bien podeis, estupendo escudero, decirle que entre, y que aquí está el valiente Caballero Don Quixote de la Mancha, de cuya condicion generosa puede prometerse con seguridad todo amparo y toda ayuda: y asimismo le podréis decir de mi parte, que si mi favor le fuere necesario, no le ha de faltar, pues ya me ticne obligado á dársele cl ser caballero, á quien es anexo y concernicnte favorecer á toda suerte de mugeres, en especial á las dueñas viudas menoscabadas y doloridas, qual lo debe
xon. Iv. 
star su Scñor Oyendo to qual Trifaldin, inclinó la rodilla hasta el suclo, $y$ haciendo al pífaro y tambores señal que tocasen, ai mismo son, y al mismo paso que habia entrado, se volvió á salir del jardin, dexando á todos admirados de su presencia y compostura. Y volviéndose el Duque á Don Quixote, le dixo : en fin, famoso caballero, no pueden las tinieblas de la malicia, ni de la ignorancia encubrir y escurecer la luz del valor y de la virtud. Digo esto, porque apénas ha scis dias que la vuestra bondad está en este castillo, quando ya os vicnen á buscar de luénas ' $y$ apartadas tierras, $y$ no en carrozas, ni en dromedarios, sino á pie, $y$ en ayúnas, los tris tes, los afligidos, confiados que han de hallar en ese fortísimo brazo el remedio de sus cuitas y trabajos : merced a vucstras grandes hazañas, que corren y rodean todo lo descubierto de la ticrra. Quisiera yo, señor Duque, respondió Don Quixote, que estuviera aquí presente aquel bendito Religioso, que á la mesa el otro dia mostró tener tan mal talante y tan mala ojeriza contra los caballeros an dantes, para que viera por vista de ojos, si los tales ca balleros son necesarios en el mundo: tocara por lo ménos con la mano, que los extraordinariamente afligidos $\mathrm{y}$ desconsolados, en casos grandes, $\mathrm{y}$ en desdichas inor mes no van á buscar su remedio á las casas de los letrados, ni á la de los sucristanes de las aldeas, ni al caballero que nunca ha acertado á salir de los términos de su Lugar, ni al perczoso cortesano, que ántes busca nuevas para referirlas y contarlas, que procura hacer obras $y$ hazañas, para que otros las cuenten y las escriban. El remedio de las cuitas, el socorro de las necesidades, el amparo de las doncellas, el consuelo de las viudas, en ninguna sucrte de personas se halla mejor, que en los caballeros andantes, $y$ de serlo yo doy infinitas gracias al Cielo, y doy por muy bien empleado qualquier desman y trabajo que en este tan honroso exercicio pueda sucederme. Venga esta dueña, y pida lo que quisiere, que yo le libraré su remedio en la fuerza de mi brazo, y en Ia intrépida resolucion de mi animoso espíritu.

\section{CAPITULO XXXVII.}

Donde se prosigue la famosa aventura de la Ducĩa Dolorida.

$\mathbf{E}_{\text {n extremo se holgáron el Duque y la Duquesa de }}$ ver quan bien iba respondiendo á su intencion Don Quixote, y á esta sazon dixo Sancho: no querria yo que esta scñora dueña pusiese algun tropiezo á la promesa de mi Gobierno, porque yo he oido decir í un boticario to ledano, que hablaba como un silguero, que donde interviniesen ducías, no podia suceder cosa buena. iVálame Dios , y que mal estaba con cllas el tal boticario! de lo que yo saco, oue pues todas las dueñas son enfadosas, é impertinentes, de qualquiera calidad y condicion que sean ¿que serán las que son doloridias, como han dicho que es esta Contesa tres faldas, ó tres colas? que en mi tierra faldas y colas, colas $y$ faldas, todo es uno. Calla, Sancho amigo, dixo Don Quixote, que pucs esta señora dueña de tan luénes tierras viene á buscarme no debe ser de aquellas que el boticario tenia en su número, quanto mas que esta es Condesa, y quando las Con desas sirven de dueñas, será sirviendo à Reynas y á Emperatrices, que en sus casas son scñorísimas, que se sirто.r. $\mathrm{W}$ 
ven de otras dueñas. Á esto respondió Doña Rodriguez, que se halló presente : dueñas tiene mi señora la Duquesa en su servicio, que pudieran ser Condesas, si la fortuna quisiera; pero allá van leyes do quieren Reycs, y nadie diga mal de las dueñas, y mas de las antiguas $y$ doncellas, que aunque jo no lo soy, bien se me alcanza y se me trasluce la ventaja que hace una dueña doncella á una dueña viuda, y quien á nosotras trasquiló, las tixeras le quedaron en la mano. Con todo eso, replicó Sancho, hay tanto que trasquilar en las dueñas, segun mi barbero, quanto será mejor no mencar el arroz, aunque se pegue. Siempre los escuderos, respondio Doña Rodr:guez, son enemigos nuestros, que como son duendes de las antesalas, y nos ven á cada paso, los ratos que no rezan (que son muchos) los gastan en murmurar de nosotras, desenterrándonos los huesos, y enterrándonos la fama. Pues mándoles yo á los leños movibles, que mal que les pese hemos de vivir en el mundo, y cn las casas principales, aunque muramos de hambre y cubramos con un negro mongil nuestras delicadas, ó no delicadas carnes, como quien cubre, ó tapa un muladar con un tapiz en dia de procesion. $\dot{A}$ fe que si me fuera dado, y el tiempo lo pidiera, que yo diera á entender, no solo á los presentes, sino á todo el mundo, como no hay virtud que no se encierre en una dueña. Yo creo, dixo la Duquesa, que mi buena Doña Rodriguez tiene razon, y muy grande ; pero conviene que aguarde tiempo para volver por sí, y por las demas dueñas, para confundir la mala opinion de aquel mal boticario y desarraigar la que tiene en su pecho el gran Sancho Panza. Á lo que Sancho respondió : despues que tengo hu-

mos de Gobernador se me han quitado los váguidos do escudero, $y$ no se me da por quantas dueñas hay un cabrahigo. Adelante pasaran con el coloquio ducñesco, si no oyeran que el pífaro y los tambores volvian á sonar, por donde entendiéron que la Dueña Dolorida entraba. Preguntó la Duquesa al Duque, si seria bien ir á recebirla, pues era Condesa, y persona principal. Por lo que ticne de Condesa, respondió Sancho ántes que el Duque respondiese, bien estoy en que vuestras grandezas salgan á recebirla; pero por lo de dueña, soy de parecer que no se muevan un paso. ¿Quien te mete á ti en esto, Sancho? dixo Don Quixote. ¿Quien, señor? respondió Sancho, yo me meto, que puedo meterme, como escudero que ha aprendido los términos de la cortesía en la escuela de vuesa merced, que es el mas cortes y bien criado caballero que hay en toda la cortesanía, y en estas cosas, segun he oido decir á vuesa merced, tanto se pierde por carta de mas, como por carta de ménos: $y$ al buen entendedor pocas palabras. Así es como Sancho dice, dixo el Duque, verémos el talle de la Condesa, y por él tantearémos la cortesía que se le debe. En esto entráron los tambores y el pífaro, como la vez primera. Y aquí con este breve capítulo dió fin el autor, y comenzó el otro, siguiendo la mesma aventura, que es una de las mas notables de la historia.

\section{CAPITULO XXXVIII.}

Donde se cuenta la que dió de su mala andanza la Dueña Dolorida.

Detras de los tristes músicos comenzáron á entrar por 
so

DON QUTOTE DE LA MATCHA

cl jardin adelante hasta cantidad de doce dueñas repartidas en dos hileras, todas restidas de unos mongiles anchos, al parecur de anascote batanado, con unas tocas blancils de delgado canequi, tan luengas, que solo el ribcte del mongil descubrian. Tras ellas venia la Contesa Tritaldi, a quien traia de la mano el escudero Trifaldin de la blanca barba, restida de finisima y negra bayera por frisar, que á venir frisada, descubriera cala grano del granior de un garbanzo de los buenos de Míltos: la cola, ó falda , ó como llamarla quinieren, era de tres nuntas, las quales se sustentaban en las manos de tres pages, asimesmo vestidos de luto, haciendo una vitosa y matemática figura, con aquellos tres úngulos acutos, que las tres puntas formaban, por lo qual caréron todos los que la falda puntiagula miriron, que por clla se debia llamar la Condesa Trifaldi, como si diécicmos, la Condesa de las tres faldas: y así dice Benengeli, que fue verdad, $y$ que de su propio apelilito se llama la Condesa Lobuna, á causa que se criaban en su Condado muchos lobos, y que si como cran lobos fucran zorras, ia llamaran la Condesa Zorruna, for ser costumbre en aquellas partes tomar los Señores la denominacion de sus nombres de la cosa, ó cosas en que mas sus Estados abundan; cmpero esta Condesa por favorecer la novedad de sa falda dexó el Lobuna, y tomó el Trifaldi. Venian las doce dueñas y la Senura á paso de procesion, cubiertos los rostros con unos velos negros, no trasparentes como el de Trifaldin, sino tan apretados, que ninguna cosa se traslucian. Así como acabó de parecer el dueñesco esquadron, el Duque, la Duquesa r. Don Quixore se pusié ron en pie, $y$ todos aquellos que la espaciosa procesion
PARTEII. CAPÍTULO XxxYII. $3^{I}$ miraban. Paráron las doce dueñas, y hiciéron calle, por medio de la qual la Dolorida se adelantó, sin dexarla de la mano Trifaldin. Viendo lo qual el Duque, la Duquesa y Don Quixote se adelantáron obra de doce pasos á recebirla. Ella puestas las rodillas en el suelo, con roz ántes basta, y ronca, que sutil y delicada, dixo: vuestras grandezas scan servidas de no hacer tanta corresía á este su criako, digo á esta su criada, porque segun soy de dolorida, no acertare á responder á lo que debo, á causa que mi extraña, y jamas vista desdicha me ha llevado el entendimiento no sé adonde, y debe de ser muy léjos, pucs quanto mas le busco, ménos le hallo. Sin él estaria, respondió el Duque, scñora Condesa, el que no descubriese por vuestra persona vuestro valor, el qual sin mas ver, es merececior de toda la nata de la cortesía, y de toda la llor de las bien criadias ceremonias: y levantándola de la mano, la llevó á asentar en una silla junto á la Duquesa, la qual ja rccibió asimismo con mucho comedimiento. Don Quixotc callaba, y Sancho andaba muerto por ver el rostro de la Trifaldi, $y$ de alguna de sus muchas dueİas ; pero no fué posible, hasta que cllas de su grado, y rolunrad se descubriéron. Sosegados todos, y puestos en silencio estaban esperando quien le habia de romper, $y$ fuć la Ducña Dolorida con estas palabras : confiada cstoy, scinor poderosísimo, hermosísima señora, y discretísimos circunstantes, que ha de hallar mi cuitísima en vuestros valerosísimos pechos acogimiento, no ménos plácido, que gencroso y doloroso, porque ella es tal, que es bastante á enternecer los mármoles, y á ablandar los diamantes, y á molificar los aceros de los mas endurecidos corazones del mundo; pero ántes que salga á la plaza de vues- 
$3^{2}$ DON CUIXOTE DE LA MANCHA

tros oidos, por no decir orejas, quisicra que me hicieran sabidori si está en este gremio, corro y companía el acendradísimo Caballero Don Quixore de la Munchisi$\mathrm{ma}$, y su escuderísimo Panza. El P’anza, ántes que otro respondicse, dixo Sancho, aquí está, y cl Don Quixotísimo asimismo, y así podréis, dolorosísima ducinisimo decir lo que quisieredisimis, que todos estamos prontos, y aparejadísimos á ser ruestros servitorísimos. En csto se levantó Don Quixore, y encaminando sus razones la Dolorida Dueña, dixo : si vuestras cuiras, angustiada señora, se pueden prometer alguna csperanza de remedio por algun valor, ó fuerzas de algun andante caballero, aquí están las mias, que aunque flacas y breves, todas se emplcarán en rucstro servicio. Yo soy Don Quixote de la Mancha, cuyo asunto es acudir á toda suerte de menesterosos : $y$ siendo esto así, como lo cs, no ha beis menester, señora, captar benevolencias, ni buscar preámbulos, sino á la llana, y sin rodeos decir vuestros males, que oidos os escuchan, que sabrán, si no remediarlos, dolerse dellos. Oyendo lo qual la Dolorida Dueña, hizo señal de querer arrojarse á los pies de Don Quixote, $y$ aun se arrojó , y pugnando por abrazárselos do cia : ante estos pies y piernas me arrojo, ó caballero invicto, por ser los que son basas y colunas de la andante caballería : estos pies quiero bcsar, de cuyos pasos pende y cuelga todo el remedio de mi desgracia. $\mathrm{O}$ valeroso andante, curas verdacieras fazañas dexan atras, y escurecen las fabulosas de los Amadises, Esplandianes y Belianises! Y dexando á Don Quixote, se volvió á Sancho Panza y as:éndole de las manos le dixo: ió tú el mas leal escudero que jamas sirvió á caballero andan-
PARTEII. CAPITULO $\mathrm{x} \times \mathrm{XVIIT}$ 33

te en los presentes, ni en los pasados siglos, mas luengo en bondad que la barba de Trifaldin mi acompañador, que está presente! bien puedes preciarte, que en servir al gran Don Quixote, sirves en cifra á toda Ia caterva de caballeros que han tratado las armas en el mundo. Conjúrote, por lo que debes á tu bondad fidelísima me seas buen intercesor con tu dueño, para que luego favorezca á esta humilísima y desdichadísima Condesa. Á lo que respondió Sancho: de que sea mi bondad, señora mia, tan Jarga y grande como la barba de vuestro escudero, á mí me hace muy poco al caso: barbada y con vigotes tenga yo mi alma quando desta vida vaya, que es lo que importa, que de las barbas de acá, poco, ó nada me curo; pero sin esas socaliñas, ni plegarias, yo rogaré á mi amo (que sé que me quiere bien, $y$ mas agora que me ha menester para cierto negocio) que favorezca y ayude á vuesa merced en todo lo que pudiere: vuesa merced desembaule su cuita, y cuéntenosla, y dexe hacer, que todos nos entenderémos. Reventaban de risa con estas cosas los Duques, como aquellos que habian tomado el pulso á la tal aventura, y alababan entre sí la agudeza y disimulacion de la Trifaldi, la qual volviéndose á sentar, dixo: del famoso Reyno de Candaya que cae entre la gran Trapobana y el mar del Sur, dos leguas mas allá del Cabo Comorin, fué Señora la Reyna Doña Maguncia, viuda del Rey Archipiela, su señor y marido, de cuyo matrimonio tuviéron y procreáron á la Infanta Antonomasia, heredera del Reyno, la qual dicha Infanta Antonomasia se crió y creció debaxo de mi tutela y doctrina, por ser yo la mas antigua y la mas principal dueña de su madre. Sucedió pues, que 
yendo dias y viniendo dias, la niña Antonomasia llegó á edad de catorce años, con tan gran perfeccion de hermosura, que no la pudo subir mas de punto la naturaleza. Pucs digamos agora que la discrecion era mocosa: así cra discreta, como bella, y era la mas bella del mundo, y lo es, si ya los hados invidiosos y las parcas endurecidas no la han cortado la estambre de la vida; pero no habrán, que no han de permitir los Cielos, que se haga tanto mal á la tierra, como seria llevarse en agraz el racimo del mas hermoso veduño del suelo. Desta hermosura, no como se debe encarecida de mi torpe lengua, se enamoró un número infinito de Príncipes, así naturales, como extrangeros, entre los quales osó levantar los pensamientos al cielo de tanta belleza, un caballero particular que en la Corre estaba, confiado en su mocedad y en su bi zarría, y en sus muchas habilidades $y$ gracias, $y$ facilidad y felicidad de ingenio, porque hago saber á vuestras grandezas, si no lo tienen por enojo, que tocaba una guitarra que la hacia hablar, y mas que cra poeta y gran baylarin, y sabia hacer una jaula de páxaros, que solamente á hacerlas pudiera ganar la vida, quando se viera en cxtrema nccesidad : que todas estas partes y gracias son bastantes á derribar una montaña, no que una delicada doncella; pero toda su gentileza y buen donayre, $y$ todas sus gracias y habilidades fueran poca, ó ninguna parte para rendir la fortaleza de mi niña, si el ladron desuella caras no usara del remedio de rendirme á mí primero. Primero quiso el malandrin y desalmado vagamundo grangearme la voluntad y coecharme el gusto, para que yo mal Alcayde le entregase las llaves de la fortaleza que guardaba. En resolucion, él me aduló el en-

PARTEII. CAPITULO XXXVIII. 35 tendimiento y me rindió la voluntad con no sé que dixes y brincos que me dió. Pero lo que mas me hizo postrar y dar conmigo por el suelo, fuéron unas coplas que le oí cantar una noche desde una reja, que caia á una callejuela donde él estaba, que si mal no me acuerdo, decian

De la dulce mi cnemiga nace un mal, que al alma hiere. $y$ por mas tormento quicre, que se sicnta, $y$ no se diga.

Parecióme la trova de perlas, y su voz de almíbar, y despues acá, digo desde entónces, viendo el mal en que caí por estos y otros semejantes versos, he considerado, que de las buenas y concertadas Repúblicas se habian de desterrar los poctas, como aconsejaba Platon, aloménos los lascivos, porque escriben unas coplas, ro como las del Marques de Mantua, que entretienen $y$ hacen llorar los niños y á las mugeres, sino unas agudezas, que á modo de blandas espinas os atraviesan el alma, y como rayos os hieren en ella, dexando sano el vestido. Y otra vez cantó

$V e n$, muerte, tan escondida, que no te sienta venir,

porque el placer del morir

no me torne á dar la vida.

$Y$ deste jaez otras coplitas y estrambotes, que cantados encantan, y escritos suspenden. ¿'Pues que quando se humillan á componer un género de verso, que en Canтом. Iv. 
$3^{6}$ DON QUIXOTE DE LA MANCHA

daya se usaba entónces, á quien ellos llamaban seguidillas? Alli era el brincar de las almas, el retozar de la risa, el desasosicgo de los cuerpos, y finalmente el azogue de todos los sentidos. $Y$ así digo, señores mios, que los tales trovadores con justo título los debian desterrar á las Islas de los lagartos. Pero no tienen ellos la culpa, sino los simples que los alaban, y las bobas que los creen $y$ si $y \circ$ fuera la buena dueña que debia, no me habian de mover sus trasnochados conceptos, ni habia de creer ser verdad aquel decir: vivo muriendo, ardo en el yelo, tiemblo en el fuego, espero sin esperanza, pártome, y quédome, con otros imposibles desta ralea, de que están sus escritos llenos.:Pues que quando prometen el Fénix de Arabia, la corona de Ariadna, los caballos del Sol, del Sur las perlas, de Tíbar el oro, y de Pancaya el bálsamo: Aquí es donde ellos alargan mas la pluma, como les cuesta poco prometer lo que jamas picnsan, ni pueden cumplir. :Pero donde me divierto : Ay de mí desdichada! ¿que locura, ó que desatino me lleva á contar las agenas faltas, teniendo tanto que decir de las mias? iAy de mí otra rez sin ventura! que no me rindieron los versos, sino mi simplicidad : no me ablandáron las músicas, sino mi liviandad: mi mucha ignorancia, $y$ mi poco advertimiento abriéron el camino y desumb senda á los pasos de Don Clavijo, que este es el nombre del referido caballero: $y$ así siendo yo la medianera, él se halló una y muy muchas reces en la estancia de la por mí, y no por él engañada Antonomasia, debaxo del título de verdadero esposo, que aunque pecadora, no consintiera que sin ser su marido la llegara á la vira de la suela de sus zapatillas. No, no, eso no, el matrimo-
PARTEII. CAPITULO XXXVII.

nio ha de ir adelante en qualquier negocio destos que por mí se tratarc. Solamente hubo un daño en este negocio, que fué el de la desigualdad, por ser Don Clavijo un caballero particular, y la Infanta Antonomasia heredera, como ya he dicho, del Reyno. Algunos dias estuvo encubicrta y solapada en la sagacidad de mi recato esta maraña, hasta que me pareció, que la iba descubriendo á mas andar no se que hinchazon del vientre de Antonomasia, cuyo temor nos hizo cntrar en bureo á los tres, y salió clél, que ántes que se saliese á luz cl mal recado, Don Clavijo pidiese ante el Vicario por su muger á Antonomasia, en fe de una cédula, que de ser su esposa la Infanta le habia hecho, notada por mi ingenio, con tanta fuerza, que las de Sanson no pudieran romperla. Hiciéronse las diligencias, vió el Vicario la cédula, tomó el tal Vicario la confesion á la Señora : confesó de plano, mandóla depositar en casa de un alguacil de corte muy honrado. $A$ esta sazon dixo Sancho i tambien en Candaya hay alguaciles de corte, poetas y segnidillas? por 10 que puedo jurar que imagino, que todo el mundo es uno; pero dese vuesa merced pricsa, señora Trifaldi, que es tarde, y ya me muero por saber el fin desta tan larga historia. Sí haré, respondió la Condesa.

\section{CAPITULO XXXIX.}

Donde la Trifaldi prosigue su estupenda y memorable historia.

De qualquiera palabra que Sancho decia, la Duquesa gustaba tanto, como se desesperaba Don Quixore, y mandándole que callase, la Dolorida prosiguió, dicien- 
do : en fin al cabo de muchas cemandas $y$ respuestas, como la Infanta se estaba siempre en sus trece, sin salir, ni variar de la primera deciaracion, el Ticario sentenció en faror de Don Clavijo, se la entregó por su lef́tima esposa, ce lo que recibio tanto cnojo la Revina Doña Maguncia, madre de la Intinca Antonomasia, que dentro de tres dias la enterrimos. Debio de morir sin ú da, dixo Sancho. Claro esti, responejó Tritaltin que en Candaya no se entierran las personas vivas, sino las muertas. Ia se ha visto, seĩor escujero, replicó Sancho, enterrar un desmavado, crevendo ser muarto, $r$ p reciame á mí, que estaba la Revra Maguncia obilgada á desmayarse ántes que á morirse, que con ia v:ذia muchas cosas se remedian, $v$ no fué ian grande el disparate de la Infanta, que obligase á sentirle tanto. Quanco se hubiera casato esa Señora con algun page suyo, o con orro criado de su casa, como han hecho otras muchas, segun he oido cecir, fuera el daño sin remedio : pero el haberse casaco con un caballero tan gentihombre, $v$ tan entendido como aquí nos le han pintajo, en verdad, en verdad, que aunque fué necedad, no tue tan grande como se piensa, porgue segun las reglas de mi señor, que esta presente, voome dexarimentir, aí como se ha cen de los hombres letrados los Obispos, se pueder hacer de los cabalieros, $r$ mas si son andantes, los Reves y los Emperadores. Razon tienes, Sancho, dixo Don Quixote, porque un caballero andante, como tenga dos dedos de ventura, está en porencia propinqua de ser el mayor Señor del mundo. Pero pase adeiante la señora Dolorida, que á mi se me trasluce que le falta por contar lo amargo desta hasta aquí dulce historia. I como si que- da lo amargo, respondió la Condesa, y tan amargo, que en su comparacion son dulces las tueras, $y$ sabrosas las adelfas. Mucrta pues la Reyna, y no desmayada, la enterrámos, y apénas la cubrímos con la ticrra, y apénas le dímos el último vale, quando ¿quis talia fando tempert i lacromis? puesto sobre un caballo de madera, pareció encima de la sepultura de la Reyna el gigante Malambruno, primo cormano de Maguncia, que junto con ser crucl, era encantador, el qual con sus artes en venganza de la muerte de su cormana, y por castigo del atrevimiento de Don Clavijo, y por despecho de la demasía de Antonomasia, los dexó encantados sobre la mesma sepultura, á clla convertida en una ximia de bronce, y á él en un espantoso cocodrilo, de un metal no conocido, y entre los dos está un padron asimismo de metal, y en él escritas en lengua siriaca unas letras, que habiéndose declarado en la candaycsca, y ahora en la castellana, encierran esta sentencia: No cobrarán su primera forma estos dos atrevidos amantes, hasta que el valeroso Manchego venga conmigo á las manos en singular batalla, que para solo su gran valor guardan los hados esta munca vista aventura. Hecho esto, sacó de la vayna un ancho y desmesurado alfange, $y$ asiéndome á mí por los cabclios hizo finta de querer segarme la gola y corrarme á cercen la cabeza. Turbéme, pegóseme la voz á la garganta, quedé mohina en todo extremo ; pero con todo me esforcé lo mas que pude, $y$ con voz tembladora $\mathrm{y}$ dolicnte le dixe tantas y tales cosas, que le hiciéron suspender la execucion de tan riguroso castigo. Finalmente hizo tracr ante sí todas las dueñas de Palacio, que fuéron estas que están presentes, $y$ despues de haber exâgerado 
DOY OUIXOTE DE IA MANCHA

nestra culpa, y vituperado las condiciones de las dueñas, sus malas mañas, y pcores trazas, y cargando á todas 1 a culpa que yo sola tenia, dixo, que no queria con pena capital castigarnos, sino con otras penas dilatadas, que nos diesen una muerte civil y continua, $y$ en aquel mismo momento y punto que acabó de decir esto, sentímos todas, que se nos abrian los poros de la cara, y que por toda ella nos punzaban como con puntas de agujas. Acudímos luego con las manos á los rostros, $y$ hallímonos de la manera que ahora veréis: y luego la Dolorida, y las demas dueñas alzáron los antifaces con que cubiertas venian, y descubriéron los rostros, todos poblados de barbas, quales rubias, quales negras, quales blancas, $¥$ quales albarrazadas, de cuya vista mostráron quedar aumirados el Duque y la Duquesa, pasmacios Don Quixore y Sancho, y atónicos todos los presentes : y la Trifaldi prosiguió : desta manera nos castigó aquel follon y mal intencionado de Malambruno, cubriendo la blandura $y$ morbidez de nuestros rostros con la aspereza destas cerdas, que pluguiera al Cielo, que ántes con su desmesurado alfange nos hubiera derribado las testas, que no que nos asombrara la luz de nuestras caras con esta borra que nos cubre : porque si entramos en cuenta, señores mios (y esto que voy á decir agora lo quisiera decir hechos mis ojos fuentes ; pero la consideracion de nuestra desgracia, y los mares que hasta aquí han llovido, los tienen sin humor, $y$ secos como aristas, $y$ así lo diré sin lágrimas) digo pues que adonde podrá ir una dueña con barbas? :que padre, ó que madre se dolerá de ella? ¿quien la dará ayuda? pues aun quando tiene la tez lisa, $y$ el rostro martirizado con mil sucrtes de menjurges
PARTEII. CAPITLIO XXXIX.

mudas, apénas halla quien bien la quiera :que hará quando descubra hecho un bosque su rostro? i ( dueñas y com pañcras mias! en desdichado punto nacímos, en hora menguada nuestros padres nos engendráron, $y$ diciendo esto dió muestras de desmayarse.

\section{CAPITULO XL.}

De cosas que atanion y tocan á esta aventura, y á esta memorabli historiat.

Real y verdaderamente todos los que gustan de semejantes historias como esta, deben de mostrarse agradecidos á Cide Hamete su autor primero, por la curiosidad que tuvo en contarnos las semínimas della, sin dexar cosa por menuda que fuese, que no la sacase á luz distintamente Pinta los pensamientos, descubre las imaginaciones, responde á las tácitas, aclara las dudas, resuclve los argumentos, finalmente, los átomos del mas curioso deseo manifiesta. ;O autor celcbérrimo! ¿O Don Quixote dicho so! ;O Dulcinea famosa! ;() Suncho Panza gracioso! Todos juntos, y cada uno de por sí vivais siglos infinitos para gusto y general pasaticmpo de los vivientes.

Dice pues la historia, que así como Sancho vió desmayada á la Dolorida, dixo: por la fe de hombre de bicn juro y por el siglo de todos mis pasados los lanzas, que jamas he oido, ni visto, ni mi amo me ha contado, ni en su pensamiento ha cabido semejante aventura como csta. Válgate mil Satanases, por no maldecirte, por cncantador y gigante Malambruno ay no hallaste otro género de castigo que dar á estas pecadoras, sino el de barbarlas? Como ¿y no fucra mejor, $y$ á ellas les es- 
tuviera mas á cucnto quitarles la mitad de las narices de medio arriba, aunque hablaran gangoso, que no ponerles barbas: Apostaré yo, que no tienen hacienda para pa gar á quien las rape. Así es la verdad, señor, respondió una de las doce, que no tenemos hacienda para mondárnos, y así hemos tomado algunas de nosorras por remedio ahorrativo de usar de unos pegotes, ó parches pegajosos, y aplicándoles á los rostros, $y$ tirando de golpe que damos rasas $y$ lisas, como fondo de mortcro de piedra, que puesto que hay en Candaya mugeres que andan de casa en casa á quitar el vello, $y$ á pulir las cejas, $y$ hacer otros menjurges tocantes á mugeres, nosotras las dueñas de mi señora por jamas quisímos admitirlas, porque las mas oliscan á terceras, habiendo dexado de ser primas: y si por cl señor Don Quixore no somos remediadas, con barbas nos llevarán á la sepultura. Yo me pelaria las mias, dixo Don Quixote, en tierra de Moros, si no remediase las vuestras. A este punto volvió de su desmayo la Trifal di , y dixo: el retintin desa promesa, valcroso caballero, en medio de mi desmayo llegó á mis oidos, $y$ ha sido parte para que yo dél vuelva, y cobre todos mis sentidos, $y$ asi de nuevo os suplico, andante ínclito, $y$ señor indomable, vuestra graciosa promesa se convierta en obra. Por mí no quedará, respondió Don Quixote : ved, señora, que es lo que tengo de hacer, que el ánimo está muy pronto para serviros. Es el caso, respondió la Dolorida, que desde aqui al Reyno de Candaya, si se va por tierra, hay cinco mil leguas, dos mas á ménos ; pero si se va por el ayre, y por la linea recta, hay tres mil y docientas y veinte $y$ siete Es tambien de suber, que Malambruno me dixo, que quando la suerte me deparase
PARIEII. CAPITUIO XI. 43

al caballero nuestro libertador, que él le enviaria una cabalgadura harto mejor, $y$ con ménos malicias que las que son de retorno, porque ha de ser aquel mesmo caballo de madera, sobre quien llevó el valeroso Piérres robada á la linda Magalona, el qual caballo se rige por una clavija que tiene en la frente, que le sirve de freno, $y$ vuela por el ayre con tanta ligereza, que parece que los mesmos diablos le llevan. Este tal caballo, segun es tradicion antigua, fué compuesto por aquel sabio Merlin. Prestósele á Piérres, que era su amigo, con el qual hizo grandes viages, y robó, como se ha dicho, á la linda Magalona, llevándola á las ancas por el ayre, dexando embobados á quantos desde la tierra los miraban, y no le prestaba, sino á quien él queria, ó mejor se lo pagaba, y desde el gran liérres hasta ahora no sabemos que haya subido alguno en él. De allí le ha sacado Malambruno con sus artes, y le tiene en su poder, $y$ se sirve dél en sus viages, que los hace por momentos por diversas partes del mundo y hoy está aquí, y mañana en Francia, y otro dia en Potosí : y es lo bueno, que cl tal caballo, ni come, ni duerme, ni gasta herraduras, y lleva un portante por los ayres, sin tener alas, que el que lleva encima, puede llevar una taza llena de agua en la mano, sin que se le derrame gota, segun camina llano y rcposado, por lo qual la linda Magalona se holgaba mucho de andar caballera en él. A esto dixo Sancho : para andar reposado y llano mi rucio, puesto que no anda por los ayres, pero por la tierra yo le cutiré con quantos portantes hay en el mundo. Riéronse todos, y la Dolorida prosiguió : y este tal caballo, si es que Malambruno quiere dar fin á nuestra desgracia, ántes que sea meron. iv. $r$ ij 
dia hora entrada la noche estara en nuestra presencia, porque él me significó, que la señal que me daria por donde yo entendiese que habia hallado el caballero que buscaba, seria enviarme el caballo donde fuese con comodidad $y$ presteza. : $Y$ quantos caben en ese caballo: preguntó Sancho. La Dolorida respondió : dos personas, Ia una en la silla, y la otra en las ancas, y por la mayor parte estas tales dos personas son caballero y escudero, quando falta alguna robada doncella. Querria yo saber, seño ra Dolorida, dixo Sancho, que nombre ticne ese caba llo. El nombre, respondió la Dolorida, no es como el caballo de Belerofonte, que se llamaba Pegaso, ni como el del Magno Alexandro, llamado Bucéphalo ni como el del furioso Orlando, cuyo nombre fué Brilladoro, ni ménos Bayarte, que fué el de Reynáldos de Montalian, ni Frontino, como el de Rugero, ni Boótes, ni Peritoa, como dicen que se llaman los del Sol ni tampoco se llama Orelia, como el caballo en que el desdichado Rodrigo, último Rey de los Godos, entró en la batalla, donde perdió la vida y el Reyno. Yo apostaré, dixo Sancho, que pues no le han dado ninguno desos famosos nombres de caballos tan conocidos, que tampoco le habrán dado el de mi amo Rocinante, que en ser propio excede á todos los que se han nombrado. Así es, respondió la barbada Condesa; pero todavía le quadra mucho, porque se llama Clavileño el Aligero yo nombre conviene con el ser de leño, y con la clavija que trae en la frente, $y$ con la ligereza con que camina, y así en quanto al nombre, bien puede competir con el famoso Rocinante. No me descontenta el nombre Sancho, pero ¿̨ con que freno, ó con que xáquima se go- bierna? Ya he dicho, respondió la Trifaldi, que con la clavija, que volviéndola á una parte, ó á otra el caballero que va encima, le hace caminar como quiere, ó ya por los ayres, ó ya rastreando, y casi barriendo la tierra, ó por el medio, que es el que se busca, y se ha de tener en todas las acciones bien ordenadas. Ya lo querria ver, respondió Sancho ; pero pensar que tengo de subir en él, ni en la silla, ni en las ancas, es pedir peras al olmo. Bueno es que apenas puedo tenerme en $\mathrm{mi}$ rucio, y sobre un albarda mas blanda que la mesma se $\mathrm{da}, \mathrm{y}$ querrian ahora que me tuviese en unas ancas de tabla, sin coxin, ni almohada alguna : pardiez yo no me pienso moler por quitar las barbas á nadie, cada qual se rape como mas le viniere á cuento, que yo no pienso acompañar á mi señor en tan largo viage, quanto mas, que yo no debo de hacer al caso para cl rapamienro destas barbas, como lo soy para el desencanto de mi Señora Duicinca. Sí sois, amigo, respondió la Trifaldi, y tanto, que sin vuestra presencia entiendo que no harémos nada. Aquí del Rey, dixo Sancho ¿que tienen que ver los escuderos con las aventuras de sus señores : ; Hanse de llevar ellos la fama de las que acaban, y hemos de llevar nosotros el trabajo? ¿Cuerpo de mí! aun si divesen los historiadores: el tal caballero acabó la tal, y tal aventura, pero con ayuda de fulano su escudero, sin el qual fucra imposible el acabarla; pero ique escriban á secas Don l'aralipómenon de las tres estrellas acabó la aventura de los seis vestiglos, sin nombrar la persona de su escudero, que se halló presente á todo, como si no fuera en el mundo! Ahora, señores, vuelvo á decir, que mi scñor se puede ir solo, y buen provecho le haga, que 
$4^{6}$

DON QUIXOTE DE LA MANCHA

yo me quedaré aquí en compañía de la Duquesa mi señora, y podria ser que quando volviese, hallase mejorada la causa de la Señora Dulcinea en tercio y quinto, porque pienso en los ratos ociosos y desocupados darme una tanda de azotes, que no me la cubra pelo. Con todo eso le habeis de acompañar si fuere necesario, bucn Sancho, porque os lo rogarán buenos, que no han de quedar por vuestro inúril temor tan poblados los rostros destas señoras, que cierto seria mal caso. Aquí del Rey, orra vez replicó Sancho, quando esta caridad se hiciera por algunas doncellas recogidas, ó por algunas niñas de la doctrina, pudiera el hombre aventurarse á qualquier trabajo ; pero que lo sufra por quitar las barbas á dueñas i mal año! mas que las viese yo á todas con barbas, desde la mayor hasta la menor, y de la mas melindrosa hasta la mas repulgada. Mal estais con las ducñas, Sancho amigo, dixo la Duquesa, mucho os vais tras la opinion del boticario toledano, pues a fe que no teneis razon, que dueñas hay en mi casa, que pueden ser exemplo de dueñas, que aquí está mi Doña Rodriguez, que no me dexará decir otra cosa. Mas que la diga Vuestra Excelencia, dixo Rodriguez, que Dios sabe la rerdad de to do, y buenas, ó malas, barbadas, ó lampiñas que seamos las dueñas, tambien nos pariéron nuestras madres, como á las otras mugeres, y pues Dios nos echó en el mundo, él sabe para que, yá su misericordia me atengo , y no á las barbas de nadie. Ahora bien, señora Rodriguez, dixo Don Quixote, y señora Trifaldi y compañía, yo espero en el Cielo que mirará con buenos ojos vuestras cuitas, que Sancho hará lo que yo le mandare, ya viniese Clavileño, y ya me viese con Malambruno, que
PARTEII. CAPÝTULOXI.

yo sé que no habria navaja que con mas facilidad rapase á vuestras mercedes, como mi espada raparia de los hombros la cabeza de Malambruno: que Dios sufre á los malos, pero no para sicmpre. ¡Ay! dixo á esta sazon la Dolorida, con benignos ojos miren á vuestra grandeza, valeroso caballero, todas las estrellas de las regiones celestes, é infundan en vuestro ánimo toda prosperidad, y valentía, para ser escudo y amparo del vituperoso, y abatido género ducñesco, abominado de boticarios, murmurado de escuderos, $y$ socalinado de pages, que mal ha ya la bcilaca que en la flor de su edad no se metió primero á ser monja , que á ducña: desdichadas de nosotras las duchas, que aunque vengamos por linea recta de varon en varon del mismo Héctor el Troyano, no dexarán de echarnos un zos nuestras seíoras, si pensasen por ello ser Rcynas. $\mathrm{O}$ gigante Malambruno, que aunque eres encantador, eres certísimo en tus promesas, envíanos ya al sin par Clavileño, para que nuestra desdicha se acabe, que si entra el calor, y estas nuestras barbas duran iguay de nuestra ventura! Dixo esto con tanto sentimiento la Trifaldi, que sacó las lágrimas de los ojos de todos los circunstantes, y aun arrasó los de Sancho, y propuso en su corazon de acompañar á su señor hasta las últimas partes del mundo, si es que en ello consistiese quitar la lana de aquellos venerables rostros.

\section{CAPITULO XLI.}

De la venida de Clavileño, con el fin desta dilatada avintura.

Llegó en esto la noche, y con ella el punto determi- 
ma en que fumoso caballo Clavileño viniese, cuya tardanza furigaba ya á Don Quixote, pareciéndole, que pues Malambruno se detenia en enviarie, ó que él no cra el caballero para quien cstaba guardada aquella arentura ó que Malanbruno no osaba venir con él á sincular batalla : pero veis aquí quando á deshora entráron por el jardin quatro salvages restidos todos de verde yedra, que sobre sus hombros traitin un gran caballo de madcra. Pusiéronie de pies en el suelo, y uno de los salvages dixo: suba sobre esta máquina el que tuviere ánimo para ello. Aquí, dixo Sancho, yo no subo, porque ni tengo inimo, ni soy caballero, y el salvage prosiguió diciendo: y ocu$\mathrm{pe}$ las ancas el escudero, si es que lo tiene, y fiese del raleroso Malambruno, que si no tuere de su espada, de ninguna otra, ni de otra malicia será ofendido, y no hay mas que torcer esta clavija, que sobre el cuello trac puesta que él los llevarí por los arres, adonde los atiende Malambruno; pero porque la alteza y sublimidad del camino no les cause váguidos, se han de cubrir los ojos, hasta que el caballo relinche, que serí señal de haber dado fin á su viage. Esto dicho, dexardo á Clavileño, con gentil continente se volviéron por donde habian venido. Ĺa Dolorida así como vió al cabalto, casi con lágrimas, dixo á Don Quixote : valeroso caballcro, las promesas de Malambruno han sido ciertas, el caballo está en casa, nuestras barbas crecen, y cada una de nosorras, $y$ con cada pelo dellas te suplicamos nos rapes y tundas, pues no está en mas, sino en que subas en él con tu cscudero, y des felice principio á vuestro nuevo viage. Eso haré yo, scñora Condesa Trifuldi, de muy buen grado $y$ de mejor talante, sin ponerme á tomar coxin, ni cal- zarme espuelas, por no detenerme : tanta es la gana que tengo de veros á vos, señora y á todas estas dueñas rasas y mondas. Eso no haré yo, dixo Sancho, ni de malo, ni de buen talante en ninguna manera, y si es que este rapamiento no se puede hacer sin que yo suba á las ancas, bien puede buscar mi señor otro escudero que le acompañe, $y$ estas señoras otro modo de alisarse los rostros, que yo no soy bruxo, para gustar de andar por los ayres : y aque dirán mis insulanos quando sepan, que su Gobernador se anda paseando por los vientos? Y otra cosa mas, que habiendo tres mil y tantas leguas de aquí á Candaya, si el caballo se cansa, ó el gigante se enoja, tardarémos en dar la vuelta media docena de años, y ya ni habrá Insula, ni ínsulos en el mundo, que me conozcan : y pues se dice comunmente que en la tardanza va el peligro, y que quando te dieren la vaquilla, acudas con la soguilla, perdónenme las barbas destas señoras, que bien se está San Pedro en Roma, quiero decir, que bien me cstoy en esta casa, donde tanta merced se me hace, y de cuyo dueño tan gran bien espero, como cs verme Gobernador. A lo que el Duque dixo : Sancho amigo, la Insula que yo os he prometido, no es movible, ni fugitiva, raices tiene tan hondas, cchadas en los abismos de Ia tierra, que no la arrancarán, ni mudarán de donde estí á tres tirones: $y$ pues vos sabeis que sé yo, que no hay ningun géncro de oficio destos de mayor cantía que no se grangée con alguna suerte de cohccho, qual mas, qual ménos, el que yo quicro llevar por este Gobierno, es que vais con vuestro señor Don Quixote á dar cima y cabo á esta memorable aventura: que ahora volvais sobre $\mathrm{Cla}$ vileño con la brevedad que su ligereza promete, ahora la том. rv. 
$5^{\circ}$ DON CUIXOTE DE IA MANCHA

contraria fortuna os traiga, y vuelva á pie hecho romero, de meson en meson, y de venta en venta, siempre que volviéredes hallaréis vuestra Insula donde la dexais, y á vuestros insulanos con el mesmo deseo de recebiros por su Gobernador, que siempre han tenido, $y$ mi voluntad será la mesma, y no pongais duda en esta verdad, señor Sancho, que seria hacer notorio agravio al deseo que de serviros tengo. No mas, señor, dixo Sancho, yo soy un pobre escudero, y no puedo llevar á cuestas tantas cortesías, suba mi amo, tápenme estos ojos, y encomiéndenme á Dios, y avísenme, si quando vamos por esas altanerías podré encomendarme á nuestro Señor, o invocar los Angeles que me favorezcan. A lo que respondió Trifaldi: Sancho, bien podeis encomendaros a Dios, ó á quien quisiéredes, que Malambruno, aunque es encantador, es christiano, y hace sus cncantamentos con mucha sagacidad, $y$ con mucho tiento, sin meterse con nadie. Ea pues, dixo Sancho, Dios me ayude, y la Santísima Trinidad de Gacta. Desde la memorable aventura de los batanes, dixo Don Quixote, nunca he visto á Sancho con tanto temor como ahora, y si yo fucIa tan agorerocomo otros, su pusilanimidad me hiciera algunas cosquillas en el ánimo: pero llegaos aquí, Sancho, que con licencia destos señores os quiero hablar aparte dos palabras : y apartando á Sancho entre unos árboles del jardin, y asiéndole ámbas las manos, le dixo: ya ves, Sancho hermano, el largo viage que nos espera, y que sabe Dios quando volverémos dél, ni la comodidad y espacio que nos darán los negocios : y así querria que ahora te retirases en tu aposento, como que vas á buscar alguna cosa necesaria para el camino, $y$ en un daca
PARTEII. CAPITULOXIT.

las pajas te dieses á buena cuenta de los tres mil y trecientos azotes, á que estás obligado, siquiera quinientos, que dados te los tendrás, que el comenzar las cosas, es tenerlas medio acabadas. Par Dios, dixo Sancho, que vuesa merced debe de ser menguado : esto es como aque11 o que dicen, en priesa me ves, $y$ doncellez me demandas ; ahora que tengo de ir sentado en una tabla rasa, quicre vuesa merced que me lastime las posas? En verdad, en verdad, que no tiene vuesa merced razon: vamos ahora á rapar estas dueñas, que á la vueita yo le prometo á vuesa merced, como quien soy, de darme tanta priesa á salir de mi obligacion, que vuesa merced se contente, y no le digo mas. Y Don Quixote respondió: pues con esa promesa, buen Sancho, voy consolado, y creo que la cumplirás, porque en efecto, aunque tonto eres hombre verídico. No soy verde, sino moreno, dixo Sancho; pero aunque fuera de mezcla cumpliera mi palabra. Y con esto se volviéron á subir en Claviieño, y al subir dixo Don Quixote: tapaos, Sancho, y subid, Sancho, que quien de tan lueñes tierras envia por nosotros, no será para engañarnos, por la poca gloria que le puede redundar de engañar á quien dél se fia : y puesto que todo sucediese al reves de lo que imagino, la gloria de haber emprendido esta hazaña, no la podrá escureccr malicia alguna. Vamos, señor, dixo Sancho, que las barbas y lágrimas destas señoras las tengo clavadas en el corazon, y no comeré bocado que bien me sepa, hasta verlas en su primera lisura. Suba vuesa merced, y tápese primero, que si yo tengo de ir á las ancas, claro está que primero sube el de la silla. Así es la verdad, replicó Don Quixote, y sacando un pańuelo de la faldrirom. sy. 
quera, pidió á la Dolorida que le cubriese muy bien los ojos, y habiéndoselos cubierto, se volvió á descubrir , y dixo: si mal no me acuerdo, yo he leido en Virgilio aquello del Paladion de Troya, que fué un caballo de madera, que los Griegos presentáron á la Diosa Pálas, el qual iba preñado de caballeros armados, que despues fućron la total ruina de Troya, y así será bien ver primero lo que Clavileńo trae en su estómago. No hay para que, dixo la Dolorida, que yo le fio, y sé que Malambruno no tiene nada de malicioso, ni de traidor: vuesa merced, señor Don Quixote, suba sin pavor alguno, y á mi daño si alguno le sucediere. Parecióle á Don Quixore que qual. quiera cosa que replicase accrea de su seguridad, seria poner en detrimento su valentía, y así sin mas altercar subió sobre Clavileño, y le tentó 1a cjavija, que fícilmente se rodeaba, y como no tenia cstribos, y le colgaban las piernas, no parecia sino figura de tapiz flamenco pintada, ó texida en algun romano triunfo. De mal talante, y poco á poco llegó á subir Sancho, y acomodándose lo mejor que pudo en las ancas, las halló algo duras, y no nada blandas, y pidió al Duque, que si fuese posible le acomodasen de algun coxin, ó de alguna almohada, aunque fuese del cstrado de su scñora la Duquesa, ó del lecho de algun page, porque las ancas de aquel caballo, mas parecian de mármol, que de leño. Á esto dixo la Trifaldi, que ningun jaez, ni ningun género de adorno sufria sobre sí Clavileño, que lo que podia hacer era ponerse á mugeriégas, y que así no sentiria tanto la dureza. Hízolo asi Sancho, y diciendo: á Dios, se dexóven dar los ojos, y ya despues de vendados se rolvió á descubrir, y mirando á todos los del jardin tiernamente, $y$

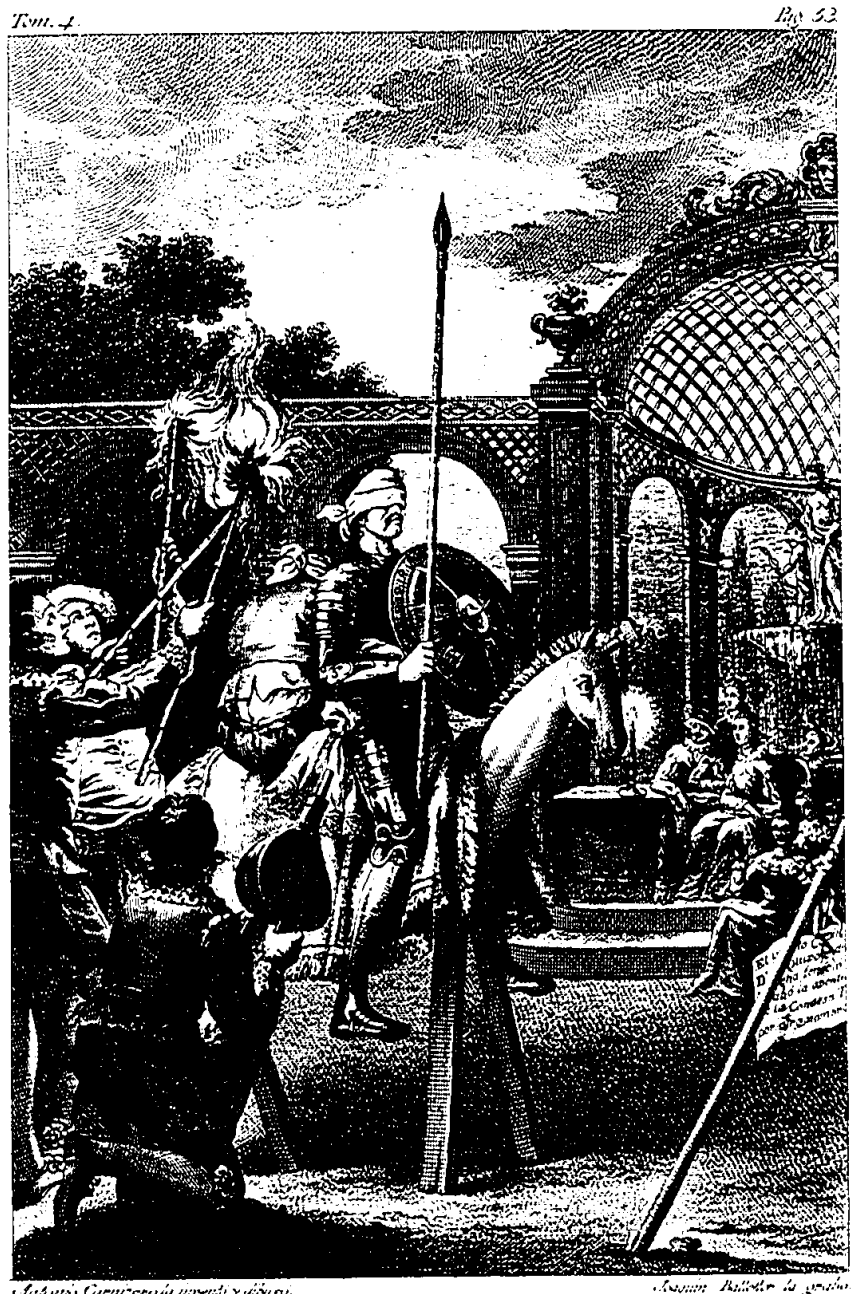


PARTEII. CAPÍTULOXI.

con lágrimas, dixo, que lc ayudasen en aquel trance $c 0$ sendos Pater nostres, $y$ sendas Ave Marias, porque Dios deparase quien por cllos los dixese, quando en semejantes trances se viesen. Á lo que dixo Don Quixote : ladron acstás puesto en la horca por ventura, ó en el último término de la vida, para usar de semejantes plegarias?: No estás, desalmada y cobarde criatura, en el mismo lugar que ocupó la linda Magalona, del qual descendió, no á la scpultura, sino á ser Reyna de Francia, si no mienten las historias, y yo que voy á tu lado, no puedo poncrme al del valcroso Piérres, que oprimió este mismo lugar, que yo ahora oprimo? Cúbrete, cúbrete, animal descorazonado, $y$ no te salga á la boca el temor que tienes, aloménos en presencia mia. Tápenme, respondió Sancho, y pues no quieren que me encomiende á Dios, ni que sea encomendado ;que muclo que tema no ande por aquí alguna region de diablos, que den con nosotros en Peralvillo? Cubriéronse, y sintiendo Don Quixote, que estaba como habia de estar, tentó la clavija, $y$ apénas hubo pucsto los dedos en ella , quando todas las dueñas, y quantos estaban presentes, levantáron las voces, diciendo: Dios te guie, valcroso caballero: Dios sea contigo, escudero intrépido, ya, ya vais por esos ayres rompićndolos con mas velocidad que una sacta, ya comenzais á suspender, y admirar á quantos desde la ticrra os cstán mirando. Tente, valcroso Sancho, que te bamboleas, mira no cayas, que será peor tu caida que la del atrevido mozo, que quiso regir el carro del Sol su padre. Oyó Sancho las voces, y apretándose con su amo, y ciñéndole con los brazos, le dixo : señor ; como dicen cstos que vamos tan altos, si alcanzan acá sus voces, y 
54

DON QUIXOTE DE LA MANCHA

no parece sino que están aquí hablando junto á nosotros: No reparcs en eso, Sancho, que como estas cosas, y estas rolaterías van fuera de los cursos ordinarios, de mil leguas verás, $\mathrm{y}$ oirás lo que quisieres, $\mathrm{y}$ no me aprictes gua veribas, $y$ en verdad que no sé de que te turbas, ni te espantas, que osaré jurar, que en todos los dias de mi vida he subido en cabalgadura de paso mas llano: no parece sino que no nos movemos de un lugar. Desticro, amigo, el miedo, que en cfecto la cosa va como ha de ir, y el viento llevamos en popa. Así es la verdad, respondió Sancho, que por este lado me da un viento tan recio, que parece que con mil fuelles me están soplando: y así era cllo que unos grandes fuelles le estaban haciendo ayre. Tan bien trazada estaba la tal aventura por el Duque y la Duquesa y su Mayordomo, que no le faltó requisito que la dexase de hacer perfecta. Sintiéndose pues soplar Don Quixote, dixo: sin duda alguna, Sancho, que ya debemos de llegar á la segunda region del ayre, adonde se engendra el granizo y las nieves: los truenos, los relámpagos, y los rayos se engendran en la tercera region: $y$ si es que desta manera vamos subiendo, presto darémos en la region del fuego, y no sé yo como templar esta clavija, para que no subamos donde nos abrasémos. En esto con unas estopas ligeras de cncenderse y apagarse, diesde léjos, pendientes de una ca nia, les calentaban los rostros. Sancho que sintió cl calor, dixo: que me maten, si no estámos ya en el lugar del fue go, ó bien cerca, porque una gran parte de mi barba se me ha chamuscado, y estoy, señor, por descubrirme, y ver en que parce estamos. No hagas tal, respondio Don Quixote, y acuérdate del verdadero cuento del Licenciado
PARTEIT. CAPÍTULOXII.

Torralva á quien lleváron los diablos en volúndas por el ayre, caballcro en una caña, ccrrados los ojos, y en doce horas llegó a Roma, y se apeó en Torre de Nona, que es una calle de la ciudad, y vió todo el fracaso, y asalto, $y$ muerte de Borbon, y por la mañana ya estaba de vuclta en Madrid, donde dió cuenta de todo lo que habia visto, el qual asimismo dixo, que quando iba por el ayre le mandó el diablo que abriese los ojos, y los abrió, y se vió tan cerca, á su parecer, del cuerpo de la luna, que la pudiera asir con la mano, y que no osó mirar á la tierra por no desvanecerse : así que, Sancho, no hay para que descubrirnos, que el que nos lleva á cargo, él dará cuenta de nosotros, y quizá vamos tomando puntas, y subiendo en alto, para dexarnos caer de una sobre el Reyno de Candaya, como hace el sacre, ó neblí sobre la garza, para cogerla, por mas que se remonte: y aunque nos parece que no ha media hora que nos partimos del jardin, crécme, que debemos de haber hecho gran camino. No sé lo que es, respondió Sancho ' Panza, solo sé decir, que si la señora Magallánes, ó Magalona, se contentó destas ancas, que no debia de ser muy ticrna de carnes. Todas estas pláticas de los dos valientes oian el Duque y la Duquesa, y los del jardin, de que recibian extraordinario contento: y queriendo dar rematc á la extraña, y bien fabricada aventura, por la cola de Clavileño le pegáron fuego con unas estopas, y al punto, por estar el caballo lleno de cohetes tronadores, voló por los ayres con extraño ruido, y dió con Don Quixote, y con Sancho Panza en el suclo medio chamuscados. En este tiempo ya se habia desparecido del jardin todo el barbado esquadron de las ducñas, y la 
Trifaldi y todo: y los del jardin quedáron como desmayados, tendidos por el suelo. Don Quixote y Sancho se levantíron maltrechos, y mirando á todas partes, quedúron atónitos de verse en el mesmo jardin de donde labian partido, y de ver tendido por tierra tanto núme ro de gente, y creció mas su admiracion, quando á un lado del jardin viéron hincada una gran lanza en el suclo, y pendiente della y de dos cordones de seda verde un pergamino liso, y blanco, en cl qual con grandes letras de oro estaba escrito lo siguiente:

El inclito Caballero Don Quixote de la Mancha foneció y' acabú laz aventura de la Condesa Trifaldi, por otro nombre llamada la Dueña Dolorida y compañia con solo intentarla.

Malambruno se da por contento y satisfecho á toda su voluntad, y las barbas de las ducrias ya quedan lisas y mondas, y los Reyes Don Clavijo y Antonomasia cn su prístino estado, y quando se cumplierel escuderil vápulo, la blanca paloma se verá libro de los pestiferos girifaltes que la persiguen, y en brazos de su querido arrullador , que asi está ordenado por el sabio Merlin, Protocncantador de los encantadores.

Habiendo pues Don Quixote leido las letras del pergamino, claro entendió que del desencanto de Dulcinca hablabun, y dando muchas gracias al Cielo, de que con tan poco peligro hubiese acabado tan gran fecho, rc duciendo á su pasada tez los rostros de las venerables dueñas, que ya no parecian, se fué adonde el Duque y la Duquesa aun no habian vuelto en sí, $y$ trabando de la mano al Duque, le dixo : ea, buen señor, buen áni-

mo, buen ánimo que todo es nada, la aventura es ya $3 \mathrm{ca}^{-}$ bada sin daño de barras, como lo muestra claro el escrito que en aquel padron está puesto. El Duque poco á poco, y como quien de un pesado sueño recuerda, fué volviendo en si, y por el mismo tenor la Duquesa, y todos los que por el jardin estaban caidos, con tales muestras de maravilla y espanto, que casi se podian dar á entender haberles acontecido de véras, lo que tan bien sabian fingir de burlas. Leyó el Duque el cartel con los ojos medio cerrados, y luego con los brazos abiertos fué á abrazar á Don Quixote, diciéndole ser el mas buen caballero que en ningun siglo se hubiese visto. Sancho andaba mirando por la Dolorida, por ver que rostro tenia sin las barbas, y si cra tan hermosa sin ellas, como su gallarda disposicion prometia ; pero dixéronle, que así como Clavileño baxó ardiendo por los ayres, y dió en el suelo, todo el csquadron de las dueñas con la Trifaldi habia desuparecido, y que ya iban rapadas y sin cañones. Pregunto la Duquesa á Sancho, que como le habia ido en aquel largo viage. Á lo qual Sancho respondió : yo, señora, sentí que íbamos, segun mi señor me dixo, volando por la region del fuego, y quise descubrirme un poco los ojos; pero mi amo, á quien pedí licencia para descubrirme, no lo consintió : mas yo que tengo no sé que briznas de curioso, y de descar saber lo que se me cstorba y impide, bonitamente, y sin que nadie lo viese, por junto á las narices aparté tanto quanto el pañizuclo, que me tapaba los ojos, y por allí miré hácia la tierra, y parecióme que toda clla no era mayor que un grano de mostaza, y los hombres que andaban sobre ella poco mayores que avellanas, porque se vea quan altos 
debíamos de ir entónces. A csto dixo la Duquesa : Sancho amigo, mirad lo que decis, que á lo que parece vos no vístes la tierra, sino los hombres que andaban sobre ella, y está claro, que si la tierra os pareció como un grano de mostaza, y cada hombre como una avellana, un hombre solo habia de cubrir toda la tierra. Así es verdad, respondió Sancho; pero con todo eso la descubrí por un Jadiro, y la vi toda. Mirad, Sancho, dixo la Duquesa, que por un ladito no se ve el todo de lo que se mira. Yo no sé esas miradas, replicó Sancho, solo sé, que será bien que Vucstra Scñoría entienda, que pues volábamos por encantamento, por encantamento polia yo ver toda la tierra, $y$ todos los hombres por do quicra que los mirara: y si esto no se me cree, tampoco crecrá vucsa merced, como descubriéndome por junto á las ccjas, me vi tan junto al cielo, que no habia de mí á él palmo y medio, y por lo que puedo jurar, señora mia, que es muy grande ademas, y sucedio que íbamos por parte donde están las siete cabrillas, y en Dios, y en mi ánima, que como yo en mi niñez fuí en mi tierra cabrerizo, que así como las vi, me dió una gana de cntretenerme con ellas un rato, y si no la cumpliera me parece que reventara. Vengo pues, y tomo, y que hago, sin decir nada á nadic, ni á mi señor timpoco, bonita y pasitamente me apeé de Clavileño, y me entreture con las cabrillas, que son como unos alhelíes, y como unas flores, casi tres quartos de hora, y Clavileño no se movió de un lugar, ni pasó adelante. Y en tanto que el buen "Sancho se entretenia con las cabras, pregunto el Duque ¿ en que se entretenia el señor Don Quixote? A lo que Don Quixote respondió : como todas estas co- sas, y estos tales sucesos van fuera del órden natural no es mucho que Sancho diga lo que dice: de mí sé decir, que ni me descubrí por alto, ni por baxo, ni vi ${ }^{~}$ el cielo, ni la tierra, ni la mar, ni las arenas. Bien es verdad que sentí que pasaba por la region del ayre, $y$ aun que tocaba á la del fuego; pero que pasásemos de allí, no lo puedo creer, pues cstando la region del fuego entre el cielo de la luna, $\mathrm{y}$ la última region del ayre, no podíamos llegar al ciclo donde están las siete cabrillas, que Sancho dice, sin abrasarnos: y pues no nos asurámos, ó Sancho micnte, ó Sancho sueña. Ni miento, ni sucño, respondió Sancho, si no pregúntenme las sernas de las tales cabras, y por ellas verán si digo verdad, ó no. Dígalas pucs, Sancho, dixo la Duquesa. Son, respondió Sancho, Ias dos verdes, las dos encarnadas, las dos azules, y la una de mezcla. Nueva manera de cabras es esa, dixo el Duque, y por esta nuestra region del suelo no se usan tales colores, digo cabras de tales colores. Bien claro está eso, dixo Sancho, sí, que diferencia lia de habcr cie las cabras del cielo á las del suclo. Dccicme, Sancho, preguntó el Duque àvístes allá cntre esas cabras algun cabron? No señor, respondió Sancho; pero oí decir, que ninguno pasaba de los cuernos de la luna. No quisiéron prequntarle mas de su viage, porque les parcció que llevaba Sancho hilo de pascarse por todos los ciclos, y dar nuevas de quanto allá pasaba, sin haberse movido del jardin. En resolucion este fué el fin de la aventura de la Ducña Dolorida, que dió que reir á los Duques, no solo aquel tiempo, sino el de toda su vida, y que contar á Sancho siglos, si los viviera, y llegándose Don Quixote á Sancho al oido, le dixo: Sancho, pues vos quereis que se том. Iv. 
os crea lo que habeis visto en el cielo, yo quiero que vos me creais á mí lo que vi en la cucva de Montesínos, $y$ no os digo mas.

\section{CAPITULO XLII.}

De los consejos que dió Don Quixote á Sancho Panza ántes que fuese á gobernar la Insula, con otras

$$
\text { cosas bian consideradas. }
$$

Con el felice y gracioso suceso de la aventura de la Dolorida, quedáron tan contentos los Duques, que determináron pasar con las burlas adelante, viendo el acomodado sugeto que tenian, para que se tuviesen por véras, y así habiendo dado la traza, y órdenes que sus criados y sus vasallos habian de guardar con Suncho en el Gobierno de la Insula prometida, otro dia, que fué el que sucedió al vuclo de Clavileño, dixo el Duque á Sancho, que se adelinase y compusiese para ir á ser Gobcrnador, que ya sus insulanos le estaban esperando como el agua de Mayo. Sancho se le humilló, y le dixo: despues que baxé del cielo, y despues que desde su alta cumbre miré la tierra, y la vi tan pequeña, se templó en parte en mí la gana que tenia tan grande de ser Gobernador, porque ¿que grandeza es mandar en un grano de mostaza, ó que dignidad, ó Imperio el gobernar á media docena de hombres tamaños como avellanas, que á mi parecer no habia mas en toda la ticrra? Si Vuestra Señoría fuese servido de darme una tantica partc del ciclo, aunque no fuese mas de media legua, la tomaria de mejor gana, que la mayor Insula del mundo. Mirad, amigo Suncho, respondió el Duque, yo no puedo dar parte del ciclo á naciie, aunque no sea mayor que una uña, que á solo Dios están reservadas esas mercedes y gracias : lo que puedo dar os doy, que es una Insula hecha y derecha, redonda, y bien proporcionada, y sobrcmanera fértil y abundosa, donde si vos os sabeis dar maña, podeis con las riquezas de la ticrra grangear las del ciclo. Ahora bien, respondió Sancho, venga esa Ínsula, que yo pugnaré por ser tal Gobernador, que á pesar de bellacos me vaya al cielo, y esto no cs por codicia que yo tenga de salir de mis casillas, ni de levantarme á mayores, sino por el deseo que tengo de probar á que sube el ser Gobernador. Si una vez lo probais, Sancho, dixo el Duque, comeros heis las manos tras cl Gobicrno, por scr dulcísima cosa el mandar, y scr obedecido. A buen seguro que quando vuestro dueño llegue á ser Emperador, que lo será sin duda, scgun van encaminadas sus cosas, que no se lo arranquen como quiera, y que le duela, y le pese en la mitad del alma del ticmpo que hubiere dexado de serlo. Scinor, replicó Suncho, yo imagino, que es bueno mandar, aunque seá á un hato de ganado. Con vos me entierren, Sancho, que sabcis de todo, respondió el Duque : yo espero que seréis tal Gobernador como vucstro juicio promcte, $y$ quédese esto aquí, y advertid, que mañana cn ese mesmo dia habeis de ir al Gobierno de la Insula, y esta tarde os acomolarín del trage conveniente que habeis de llevar, $y$ de todas las cosas necesarias á vuestra partida. Vistanme, dixo Sancho, como quisieren, que de qualquier manera que vava vestido, seré Sancho Panza. Así es rerdad, dixo el Duque; pero los trages se han de acomodar con el oficio, ó dignidad que se profesa, que no 
seria bien, que un jurisperito se vistiese como soldado ni un soldado como un Sacerdote. Vos, Sancho, iréis vestido parte de letrado, y parte de capitan, porque en la Insula que os doy, tanto son menester las armas como las letras, $y$ las letras como las armas. Letras, respondió Sancho, pocas tengo, porque aun no sé el A. B. C, pero bástame tener el Christzis en la memoria , para ser buen Gobernador. De las armas manejaré las que me diercn hasta caer, y Dios delante. Con tan buena memoria, dixo el Duque, no podrá Suncho crrar en nada. En esto llegó Don Quixote, y sabiendo lo que pasaba, y la celeridad con que Sancho se luabia de partir á su Gobierno, con licencia del Duque le tomó por la mano, y se fué con él á su estancia con intencion de aconsejarle como se habia de haber en su oficio. Entrados pucs en su aposento, cerró tras sí la puerta, y hizo casi por fuerza que Sancho se sentase junto á él, y con reposada voz le dixo:

Infinitas gracias doy al Cielo, Sancho amigo, de que ántes, $y$ primero que yo haya encontrado con alguna buena dicha, te haya salido á ti á recebir y á encontrar la buena ventura. Yo que en mi buena sucrte te tenia librada la paga de tus servicios, me veo en los principios de aventajarme, $y$ tú ántes de tiempo, contra la ley del razonable discurso, te ves premindo de tus deseos. Otros cohechan, importunan, solicitan, madrugan, rucgan, porfian, $y$ no alcanzan lo que pretenden, y llega otro, $y$ sin saber como, ni como no, se halla con el cargo y ofcio, que otros muchos pretendiéron, y aquí entra y encaxa bien el decir, que hay buena y mala fortuna en las pretensiones. Tú, que para mí sin duda alguna eres un porro, sin madrugar, ni trasnochar, y sin hacer diligencia alguna, con solo el alicnto que te ha tocado de la andante caballería, sin mas, ni mas te ves Gobernador de una Insula, como quien no dice nada. Todo esto digo, ó Sancho, para que no atribuyas á tus merecimientos la merced recebida, sino que des gracias al Cielo, que dispone suavennente las cosas, y despues las darás á la grandeza, que en sí encierra la profesion de la caballería andante. Dispuesto pues el corazon á creer lo que te he dicho, está, o hijo, atento á este tu Caton, que quicre aconsejarte, $y$ ser norte y guia, que te encamine y saque á seguro puerto deste mar proceloso donde vas á engolfarte : que los oficios y grandes cargos no son orra cosa sino un golfo profundo de confusiones.

Primcramente, ó hijo, has de temer á Dios, porque en el temerle está la sabiduria, y siendo sabio, no podrás crrar en nada.

Lo segundo, has de poner los ojos en quien eres, procurando conocertc á ti mismo, que es el mas difícil conocimiento que puede imaginarse. Del conoccrte saldrá el no hincharte como la rana, que quiso igualarse con cl buey, que si esto haces vendrá á ser feos pies de la rucda de tu locura la consideracion de haber guardado puercos en tu tierra. Así es la verdad, respondió Sancho, pero fué quando muchacho; pero despues algo lombrecillo, gansos fuéron los que guardé, que no puercos; pero esto paréceme á mí que no hace al caso , que no todos los que gobicrnan vienen de casta de Reyes. Así es verdad, replicó Don Quixote, por lo qual los no de principios nobles deben acompañar la gravedad del cargo que exercitan con una blanda suavidad, que guia- 
da por la prudencia los libre de la murmuracion maliciosa, de quien no hay estado que se escape.

Haz gala, Sancho, de la humildad de tu linage, y no te desprecies de decir que vienes de labradores, porque viendo que no te corres, ninguno se pondrá á correrte, y préciate mas de ser humilde virtuoso, que pecador soberbio. Innumerables son aquellos que de baxa estirpe nacidos, han subido á la suma dignidad Pontifcia , é Imperatoria , y desta verdad te pudiera traer tantos exemplos ${ }^{\circ}$ que te cansaran.

Mira, Sancho, si tomas por medio á la virtud, y te precias de hacer hechos virtuosos, no hay para que tener envidia í los que los tienen Príncipes y Señores, porque la sangre se hereda, y la virtud se aquista, y la virtud vale por sí sola, lo que la sangre no vale.

Siendo esto así, como lo es, si acaso viniere á verte quando estés en tu Insula alguno de tus parientes, no le deseches, ni le afrentes, ántes le has de acoger, agasajar, y regalar, que con esto satisfarás al Cielo, que gusta que nadie se desprecie de lo que él hizo, y corresponderás á lo que debes á la naturalcza bien concertada.

Si truxeres á tu muger contigo (porque no es bien que los que asisten á Gobiernos de mucho tiempo estén sin las propias) enséñala, dotrínala , y desbástala de su natural rudeza, porque todo lo que suele adquirir un Gobernador discreto, sucle perder y derramar una muger rústica y tonta.

$\mathrm{Si}$ acaso enviudares (cosa que puede suceder) y con el cargo mejorares de consorte, no la tomes tal que te sirva de anzuelo y de caña de pescar, y del no quie-
To de tu capilla, porque en verdad te digo, que de todo aquello que la muger del Juez recibiere, ha de dar cuenta el marido en la residencia universal, donde pagará con el quatro tanto en la muerte las partidas de que no se hubiere hecho cargo en la vida.

Nunca te guies por la ley del encaxe, que suele tener mucha cabida con los ignorantes, que presumen de agudos.

Hallen en ti mas compasion las lágrimas del pobre; pero no mas justicia que las informaciones del rico.

Procura descubrir la verdad por entre las promesas y dádivas del rico, como por entre los sollozos, é importunidades del pobre.

Quando pudiere, y debiere tener lugar la equidad, no cargues todo el rigor de la ley al delinquiente, que no es mejor la fana del Juez riguroso, que la del compasivo.

Si acaso doblares la vara de la justicia, no sea con el peso de la dádiva, sino con el de la misericordia.

Quando te sucediere juzgar algun pleyto de algun tu enemigo, aparta las miéntes de tu injuria, y ponlas en la verdad del caso.

No te ciegue la pasion propia en la causa agena, que los yerros que en ella hicieres, las mas veces serán sin remedio, y si le tuvieren será á costa de tu crédito, y aun de tu hacienda.

Si alguna muger hermosa viniere á pedirte justicia, quita los ojos de sus lágrimas, y tus cidos de sus gemidos, y considera despacio la sustancia de lo que pide, si no quieres que se anegue tu razon en su llanto, $y$ tu bondad en sus suspiros.

Iом. Iv. 
Al que has de castigar con obras, no trates mal con palabras, pucs le basta al desdichado la pena del suplicio, sin la añadidura de las malas razones.

Al culpado que cayere debaxo de tu juridicion, considérale hombre miserable sujeto á las condiciones de la depravada naturaleza nuestra, $y$ en todo quanto fucre de tu parte, sin hacer agravio á la contraria, muéstratele piadoso y clemente, porque aunque los atributos de Dios todos son iguales, mas resplandece y campea á nucstro ver el de la misericordia, que el de la justicia.

$\mathrm{Si}$ estos preceptos, y estas reglas sigues, Sancho, serín luengos tus dias, tu fama será cterna, tus premios colmados, tu felicidad indecible, casarás tus hijos como quisieres, títulos tendrún cllos $\mathrm{y}$ tus nictos, vivirás en paz y beneplácito de las gentes, y cn los últimos pasos de la vida te alcanzará el de la muerte en rejez suave y madura, y cerrarán tus ojos las tiernas y delicadas manos de tus terceros netezuelos. Esto que hasta aquí te he dicho, son documentos que han de adornar tu alma, escucha ahora los que han de servir para adorno del cuerpo.

\section{CAPÍTULO XLIII.}

De los consejos segundos que dió Don Quixote

$$
\text { á Sancho Panza. }
$$

¿Quien oyera el pasado razonamiento de Don Quixote, que no le tuviera por persona muy cuerda, y mcjor in tencionada? Pero como muchas veces en el progreso desta grande historia queda dicho, solamente disparaba en tocándole en la caballería y en los demas discursos mostraba tener claro, $y$ desenfadado entendimiento, dema-

nera, que a cada paso desacreditaban sus obras su juicio y su juicio sus obras ; pero en esta destos segundos documentos que dió á Sancho, mostró tener gran donayre, $y$ puso su discrecion $y$ su locura en un levantado punto. Atentísimamente le escuchaba Sancho, y procuraba conscrvar en la memoria sus consejos, como quien pensaba guardarlos, y salir por ellos á buen parto de la preñez de su Gobierno. Prosiguió pues Don Quixote, y dixo:

En lo que toca á como has de gobernar tu persona y casa, Sancho, lo primero que te encargo es, que seas limpio, y que te cortes las uñas, sin dexarlas crecer como algunos hacen, á quien su ignorancia les ha dado á entender, que las uñas largas les hermosean las manos, como si aquel cxcremento, y añadidura que se dexan de cortar, fuese uña, siendo ántes garras de cernícalo lagartijero: pucrco y cxtraordinario abuso.

No andes, Sancho, desceñido y floxo, que el vestido descompuesto da indicios de ánimo desmazalado, si ya la descompostura y floxedad no cae debaxo de socarronería, como se juzgó en la de Julio César.

Toma con discrecion el pulso á lo que pudiere valer tu oficio, y si sufricre que des librea á tus criados, dáscla honesta y provechosa, mas que vistosa y bizarra, y repártela cntre tus criados y los pobres : quiero decir, que si has de vestir scis pages, viste tres, y otros tres pobres, $y$ así tendrás pages para el Cielo y para el suclo : y este nuevo modo de dar librea no le alcanzan los vanagloriosos.

No comas ajos, ni cebollas, porque no saquen por el olor tu villancría: anda despacio, habla con reposo; 
pero no demanera, que parezca que te escuchas á ti mismo que toda afectacion es mala.

Come poco, y cena mas poco, que la salud de todo el cuerpo se fragua en la oficina del estómago.

Sé templado en el beber, considerando que el vino demasiado, ni guarda secreto, ni cumple palabra.

Ten cuenta, Sancho, de no mascar á dos carrillos, ni de erutar delante de nadie. Eso de erutar no cntiendo, dixo Sancho, y Don Quixote le dixo: erutar, Sancho, quiere decir, regoldar, y este es uno de los mas torpes vocablos que tiene la lengua castellana, aunque es muy sinificativo, $y$ así la gente curiosa se ha acogido al latin, y al regoldar, dice erutar, y á los regüeldos erutaciones : y quando algunos no entiendan estos términos, importa poco, que el uso los irá introduciendo con el tiempo, que con facilidad se entienden, $y$ esto es enriquecer la lengua, sobre quien tiene poder el vulgo y el uso. En verdad, señor, dixo Sancho, que uno de los consejos $\mathrm{y}$ avisos que pienso llevar en la memoria, ha de ser el de no regoldar, porque lo suclo hacer muy á menudo. Erutar, Sancho, que no regoldar, dixo Don Quirote. Erutar diré de aquí adelante, respondió Sancho, y á fe que no se me olvide.

Tambien, Sancho, no has de mezclar en tus pláticas la muchedumbre de refranes que sueles, que puesto que los refranes son sentencias breves, muchas veces los traes tan por los cabellos, que mas parecen disparates, que sentencias. Eso Dios lo puede remediar, respondió Sancho, porque sé mas refranes que un libro, y viénenseme tantos juntos á la boca quando hablo, que riñon por salir unos con otros; pero la lengua va arrojando los pri- meros que encuentra, aunque no vengan á pelo; mas yo tendré cuenta de aquí adelante de decir los que convengan á la gravedad de mi cargo, que en casa llena, presto se guisa la cena, y quien destaja no baraja, y á buen salvo está el que repica, y el dar y el tener, seso ha menester. Eso sí, Sancho, dixo Don Quixote, encaxa, ensarta, enhila refranes, que nadie te va á la mano: castígame mi madre, y yo trompógelas. Estoyte diciendo, que excuses refranes, $y$ en un instante has echado aquí una letanía dellos, que así quadran con lo que vamos tratando, como por los cerros de Ubeda. Mira, Sancho, no te digo yo que parece mal un refran traido á propósito; pero cargar" ", y ensartar refranes á troche moche, hace la plática desmayada y baxa.

Quando subieres á caballo, no vayas echando el cuerpo sobrc el arzon postrero, ni lleves las piernas tiesas y tiradas, y desviadas de la barriga del caballo, ni tampoco vayas tan floxo, que parezca que vas sobre el rucio, que el andar á caballo á unos hace caballeros, á otros caballerizas.

Sea moderado tu sueño, que el que no madruga con el sol, no goza del dia: y advierte, ó Sancho, que la di ligencia es madre de la buena ventura, y la pereza su contraria jamas llegó al término que pide un buen deseo.

Este último consejo que ahora darte quiero, puesto que no sirva para adorno del cuerpo, quiero que le lleves muy en la memoria, que creo que no te será de ménos provecho, que los que hasta aquí te he dado, y es: que jamas te pongas á disputar de linages, aloménos comparándolos entre sí, pues por fuerza en los que se comparan, uno ha de ser el mejor, y del que abatieres serás aborre- 
DON QUIXOTE DE IA MANCHA

cido, $y$ del que levantares en ninguna manera premiado. Tu vestido será calza entera, ropilla larga, herreruclo un poco mas largo, gregüicscos ni por pienso, que no les cstán bien, ni á los caballeros, ni á los Gobernadores.

Por ahora csto se me ha ofrecido, Sancho, que aconsejarte, andarí el tiempo, y segun las ocasiones, así serán mis documentos, como tú tengas cuidado de avisarme el cstado en que te hallares. Señor, respondió Sancho, bien veo que todo quanto vuesa merced me ha dicho son cosas buenas, santas y provechosas ipero de que han de servir, si de ninguna me acuerdo! Verdad sea, que aquello de no dexarme crecer las uñas, y de casarme otra vez, si se ofreciere, no se me pasará del magin; pero esotros badulaques, y enredos y revolrillos, no se me acuerda, ni acordará mas dellos, que de las nubes de antaño, y así será menester, que se me den por escrito, que puesto que no sé leer, ni escribir, yo se los daré á mi confesor para que me los encaxe y recapacite quando fuere menester. ¡Ha pecador de mi! respondió Don Quixote : y que mal parece en los Gobernadores el no saber lecr, ni escribir, porque has de saber, ó Sancho, que no saber un hombre lecr, ó ser zurdo, arguye una de dos cosas, ó que fué hijo de padres demasiado de humildes y baxos, ó él tan travieso y malo, que no pudo entrar en él el buen uso, ni la buena dotrina. Gran falta es la que llevas contigo, y así querria que aprendieses á firmar siquiera. Bien sć firmar mi nombre, respondió Sancho, que quando fuí l'rioste en mi Lugar aprendí á hacer unas lctras como de marca de fardo, que decian que decia mi nombre, quanto mas que fingiré que tengo tullida la mano derecha, y haré que firme otro por mí, que para to-
PARTE II. CAPITULO XIIII.

do hay remedio, sino es para la muerte, $y$ teniendo yo el mando y el palo, haré lo que quisiere : quanto mas, que el que tiene el padre Alcalde, y sicndo yo Gobernador, que es mas que ser Alcalde, llegaos, que la dexan ver, no sino popen, y calónenme, que vendrán por lana, y volverán trasquilados, y á quien Dios quicre bien, la casa le sabe, $y$ las necedades del rico por sentencias pasan en el mundo, $y$ siéndolo yo, siendo Gobernador, y juntamente liberal, como lo pienso ser, no habrá falta que se me parezca : no sino hacéos miel, y papáros han moscas: tanto vales quanto tienes, decia una mi agüela, y del hombre arraigado no te verás vengado. ;Ó maldito seas de Dios, Sancho! dixo á esta sazon Don Quixote: sesenta mil Satanases te lleven á ti y á tus refranes: una hora ha que los estas ensartando, $\mathrm{y}$ dándome con cada uno tragos de tormento. Yo te aseguro, que estos refranes te han de llevar un dia á la horca, por ellos te han de quitar el Gobierno tus vasallos, ó ha de haber entre ellos comunidades. Dime ; donde los hallas, ignorante? ¿ó como los aplicas, mentecato? que para decir yo uno, $y$ aplicarle bien, sudo y trabajo como si cavase. Por Dios, señor nuestro amo, replicó Sancho, que vuesa merced se queja de bien pocas cosas. Á que diablos se pudre de que yo me sirva de mi hacienda, que ninguna otra tengo, ni otro caudal alguno, sino refranes y mas refranes, y ahora se me ofrecen quatro, que venian aquí pintiparados, ó como peras en tabaque, pero no los diré, porque al buen callar llaman Sancho. Ese Sancho no eres tú, dixo Don Quixote, porque no solo no eres buen callar, sino mal hablar, y mal porfiar, $y$ con todo eso querria saber que quatro refranes te ocurrian 
aliora á la memoria, que venian aquí á propósito, que yo ando recorriendo la mia, que la tengo buena, $y$ ninguno se me ofrece. Que mejores, dixo Sancho, que entre dos muelas cordales nunca pongas tus pulgares. $\mathrm{Y}$, á ídos de mi casa, $y$ que quereis con mi muger, no hay responder. $Y$, si da el cántaro en la piedra, ó la piedra en el cántaro, mal para el cántaro: todos los quales vienen á pelo. Que nadie se tome con su Gobernador, ni con el que le manda, porque saldrá lastimado, como el que pone el dedo entre dos muelas cordales, $y$ aunque no sean cordales, como sean muelas no importa, $y$ á lo que dixere el Gobernador no hay que replicar, como al salíos de mi casa, y que quereis con mi muger: pues lo de la piedra en el cántaro un ciego lo verá. Así que es menester, que el que ve la mota en el ojo ageno, vea la viga en el suyo, porque no se diga por él : espantóse la mucrta de la degollada, y vuesa merced sabe bien, que mas sabe el necio en su casa, que el cuerdo en la agena. Eso no, Sancho, respondió Don Quixote, que el necio, en su casa, ni en la agena sabe nada, á causa que sobre el cimiento de la necedad no asienta ningun discreto edificio: y dexemos esto aquí, Sancho, que si mal gobernares, tuya será la culpa , y mia la vergüenza; mas consuélome, que he hecho lo que debia en aconsejarte con las véras y con la discrecion á mí posible : con esto salgo de mi obligacion, y de mi promesa: Dios te guie, Sancho, y tc gobierne cn tu Gobierno , y á mí me saque del escrúpulo que me queda, que has de dar con toda la Ínsula patas arriba, cosa que pudiera yo excusar con descubrir al Duque quien eres, diciéndole, que toda esa gordura, $\mathrm{y}$ esa personi1la que tienes, no es otra cosa, que un costal lleno de

Iefranes y de malicias. Seíor, replicó Sancho si á ruesa merced le parece que no soy de pro para este Gobierno, desde aquí le suelto, que mas quiero un solo negro de la uña de mi alma, que í todo mi cuerpo, y así me sustentaré Sancho á secas con pan y cebolla, como Gobernador con perdices y capones, $y$ mas que miéntras se ducrme, todos son iguales los grandes y los menores, los pobres y los ricos, y si vuesa merced mira en ello, verí que solo vuesa merced me ha puesto en esto de gobernar, que yo no sé mas de Gobiernos de İnsulas, que un buytre : y si se imagina que por ser Gobernador me

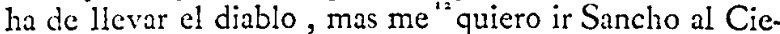
lo, que Gobernador al infierno. Por Dios, Sancho, dixo Don Quixore, que por solas estas últimas razones que has dicho, juzgo que mereces ser Gobernador de mil Insulas: buen natural tienes, sin el qual no hay ciencia que valga: encomiéndate á Dios, y procura no crrar en la primera intencion : quicro decir, que siempre tengas intento, $y$ frrme propósito de acertar en quantos negocios te ocurrieren, porque siempre favorece el Cielo los buenos deseos, y vámonos á comer, que creo que ya estos Señores nos aguardan.

\section{CAPITULO XLIV.}

Como Sancho Panza fué llevado al Gobierno, y de la extraña aventura que en el castillo sucedió á Don Quixote.

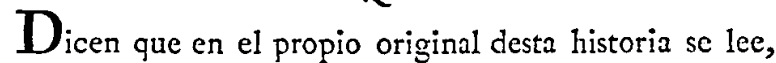
que llegando Cide Hamete á escribir este capítulo, no le traduxo su intérprete como él le habia escrito, que Gué том. Jv. 
un modo de queja que tuvo el Moro de si mismo, por haber romado entre manos una historia tan seca, y tan limitada como esta de Don Quixote, por parecerle que siempre habia de hablar dél y de Sancho, sin osar extenderse á otras digresiones y episodios mas graves y mas entretenicos, y decia, que el ir sicmpre ateniclo el cntendimiento, la mano y la pluma á escribir de un solo sugeto, $y$ hablar por las bocas de pocas personas, era un trabajo incomportable, cuyo fruto no redundaba en cl de su autor, y que por huir deste inconrenicnte, habia usado en la primera parte del artificio de algunas novelas, como fucron la del Carioso imfertinente, y la del Capitan cautivo, que están como separadas de la historia, puesto que las demas que alli se cuentan son casos succdidos al mismo Don Quixote, que no podian dexar de escribirse. Tambien pensó, como él dice, que muchos llevados de la atencion que piden las hazañas de J)on Quixote, no la darian á las novelas, y pasarian por cllas, ó con pricsa, ó con cnfado, sin advertir la gala y artificio que en sí contienen, el qual se mostrara bien al descubicrto, quando por sí solas, sin arrimarse á las locuras de Don Quixote, ni á las sandeces de Sancho salieran á luz: y así en esta segunda parte no quiso ingerir novelas sucltas, ni pegadizas, sino algunos episodios que lo pareciesen, nacidos de los mesmos sucesos que la verdad ofrece, $y$ aun estos limitadamente, $y$ con solas las palabras que bastan á declararlos: y pues se contiene y cierra en los estrechos límites de la narracion, teniendo habilidad, suficiencia y entendimiento para tratar del universo todo, pide no se desprecie su trabajo, $y$ se le den alabanzas, no por lo que escribc, sino por to que ha devado de cscribir: y luceo prosigue la his toria, diciendo, que en acabando de comer Don Quixote el dia que dió los conscjos á Sancho, aquella tarde se los dió escritos, para que él buscase quien se los leyese; pero apénas se los hubo dado, quando se le cayéron, y vinićron á manos del Duque, que los comunicó con la Duquesa, y los dos se admiráron de nuevo de la locura y del ingenio de Don Quixote y así llevando adelante sus burlas, aquella tarde enviáron á Sancho con mucho acompanamiento al Lugar, que para él habia de ser Insula. Acacció, pucs, que el que le llevaba á cargo cra un mayordomo del Duque, muy discreto y muy gracioso, que no puede laber gracia donde no hay discrecion, el qual habia hecho la persona de la Condesa Trifaldi con el donayre que queda referido, $y$ con esto,$y$ con ir industriado de sus señores de como se habia de haber con Sancho, salió con su intento maravillosamente. Digo pues, que acació, que así como Sancho vió al tal mayordomo, se le figuró en su rostro el mesmo de la Trifaldi, y volviéndose á su scinor, le dixo: scñor, ó á mí me ha de llevar el diablo de aquí de donde estoy, en justo y en creyente, ó vuesa merced me ha de confesar, que el rostro deste mayordomo del Duque, que aquí está, es el mesmo de la Dolorida. Miró Don Quixote atentamente al mayordomo, y habiéndole mirado, dixo á Sancho: no hay para que te lleve el diablo, Sancho, ni en justo, ni en creyente (que no sé lo que quicres decir) que el rostro de la Dolorida es el del mayordomo; pero no por eso el mayordomo es la Dolorida, que á scrlo, implicaria contradicion muy grande, y no es tiempo ahora de hacer estas averiguaciones, que scria rom. iv. 
entrarnos en intricados laberintos. Crecme, amigo, que es menester rogar á nuestro Señor muy de véras, que nos libre á los dos de malos hechiceros, y de malos encantadores. No es burla, señor, replicó Sancho, sino que deníntes le oí hablar, y no pareció sino que la voz de la Trifaldi me sonaba en los oidos. Ahora bien, yo callaré ; pero no dexaré de andar advertido de aquí adclante, á ver si descubre otra señal, que confirme, ó desfaga mi sospecha. Así lo has de hacer, Sancho, dixo Don Quixote, y darásme aviso de todo lo que en este caso descubrieres, y de todo aquello que en el Gobierno te sucediere. Salió en fin Sancho acompañado de mucha gente, vestido á lo Letrado, y encima un gaban muy ancho de chamelote de aguas leonado, con una montera de lo mesmo, sobre un macho á la gineta, y detras dél , por órden del Duque, iba el rucio con jaeces y ornamentos jumentiles de seda y flamantes. Volvia Sancho la cabeza de quando en quando á mirar á su asno, con cuya compañía iba tan contento, que no se trocara con el Emperador de Alemaña.

$\mathrm{Al}$ despedirse de los Duques, les besó las manos, y tomó la bendicion de su señor, que se la dió con lágrimas, y Sancho la recibió con pucheritos. Dexa, lector amable, ir en paz, y en hora buena al buen Sancho, y espera dos fanegas de risa que te ha de causar el saber como se portó en su cargo, y en tanto atiende á saber lo que le pasó á su amo aquelia noche, que si con ello no rieres, por lo ménos desplegarás los labios con risa de ximia, porque los sucesos de Don Quixote, ó se han de celebrar con admiracion, ó con risa. Cuéntase pucs, que apénas se hubo partido Sancho, quando Don Quixote sintió su soledad,

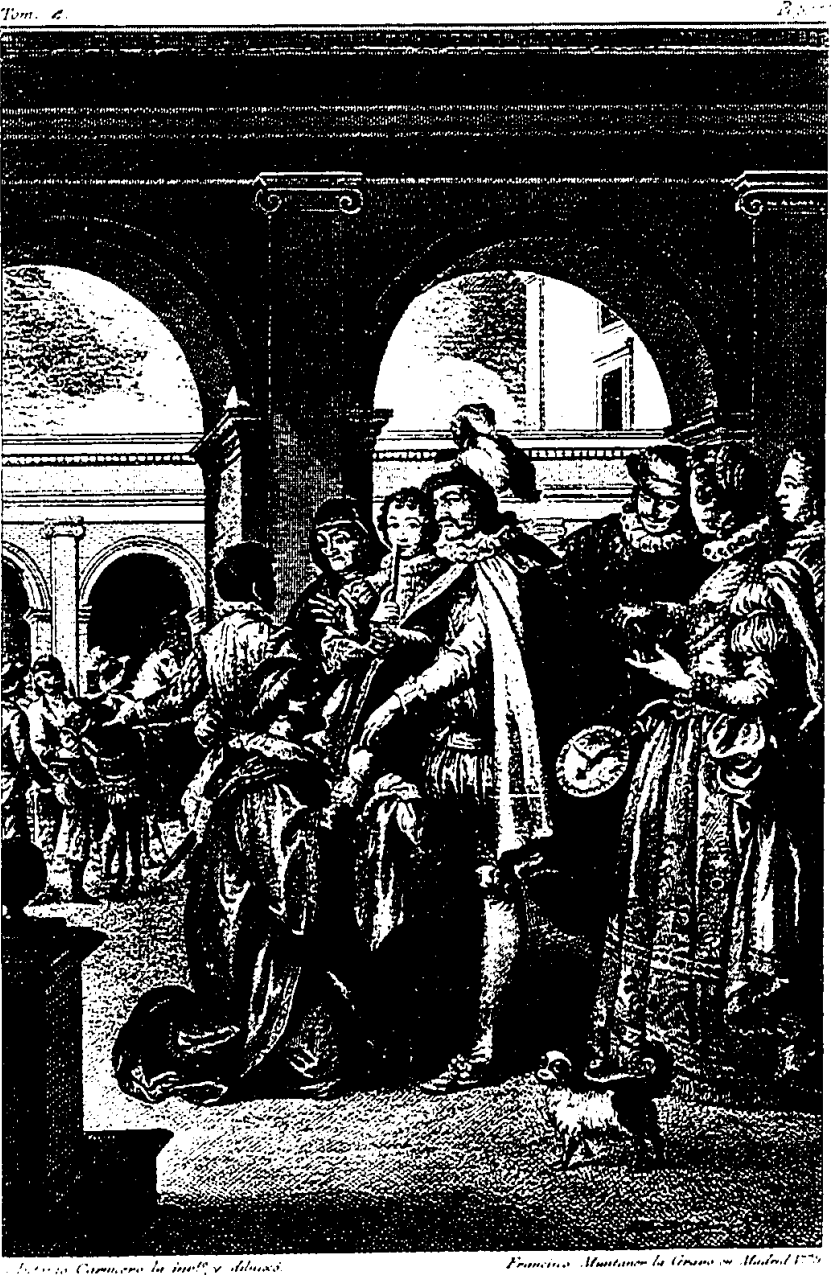


PARTEIT. CAPÍTULO XLIV.

$y$ si le fucra posible revocarle la comision, $y$ quitarle el Gobicrno, lo hiciera. Conoció la Duquesa su melancolía, y preguntóle, que de que estaba triste, que si era por la ausencia de Sancho, que cscuderos, dueñas y doncellas habia en su casa, que le servirian muy á satisfacion de su deseo. Verdad es, señora mia, respondió Don Quixote, que siento la ausencia de Sancho; pero no es esa la causa principal que me hace parecer que estoy triste, $y$ de los muchos ofrecimientos que Vuestra Excelencia me hace, solamente acepto y escojo el de la voluntad con que se me hacen, $y$ en lo demas suplico á Vuestra Excelencia, que dentro de mi aposento consienta y permita que yo solo sea cl que me sirva. En verdad, dixo la Duquesa, scñor Don Quixote, que no ha de ser así, que le han de servir quatro doncellas de las mias, hermosas como unas flores. Para mí, respondió Don Quixote, no scrán ellas como flores, sino como espinas, que me puncen el alma. Así cntrarún cllas en mi aposento, ni cosa que lo parezca, como volar. Si es que vuestra grandcza quicre llevar adelante el hacerme merced, sin yo merccerla, déxeme que yo me las haya conmigo, $y$ que yo me sirva de mis pucrtas adentro, que yo ponga una munlla cn medio de mis descos y de mi honestidad: y no quicro perder esta costumbre por la liberalidad que Vucstra Alteza quiere mostrar conmigo: y en resolucion, ántes dormiré vestido, que consentir que nadie me desnude. No mas, no mas, señor Don Quixore, replicó la Duquesa : por mí digo, que daré órden, que ni aun una mosca entre en su estancia, no que una doncella : no soy yo persona que por mí se ha de descabalar la decencia del señor Don Quixote, que segun se me ha traslucido, 
la que mas campea entre sus muchas virtudes, es la de la honestidad. Desnúdese vuesa merced, y vístase á sus solas, $y$ á su modo, como y quando quisiere, que no habrá quien lo impida, pues dentro de su aposento hallará los vasos necesarios al menester del que duerme á pucrta cerrada, porque ninguna natural necesidad le oblique á que la abra. Viva mil siglos la gran Dulcinea del Toboso, y sea su nombre extendido por toda la redondez de la tierra, pues mereció ser amada de tan valiente $y$ tan honesto caballero, y los benignos Ciclos infundan en el corazon de Sancho Panza nuestro Gobernador un desco de acabar presto sus diciplinas, para que vuclra á gozar el mundo de la belleza de tan gran Scinora. A lo qual dixo Don Quixote: vuestra altitud ha hablado como quien es, que en la boca de las buenas Señoras no ha de haber ninguna que sea mala: $y$ mas venturosa y mas conocida será en el mundo Dulcinea, por habcrla alabado vuestra grandeza, que por todas las alabanzas que puedan darle los mas eloqüentes de la tierra. Agora bien, señor Don Quixote, replicó la Duquesa, la hora de cenar se llega, y el Duque debe de esperar, venga vucsa merced, y cenemos, y acostaráse temprano, que el viage que ayer hizo de Candaya, no fué tan corto, que no haya causado algun molimiento. No siento ninguno, señora, respondió Don Quixote, porque osaré jurar á Vuestra Excelencia, que en mi vida he subido sobre bestia mas reposada, ni de mejor paso que Clavileño, y no sé yo que le pudo mover á Malambruno para deshaccrse de tan ligera y tan gentil cabalgadura, y abrasarla así sin mas, ni mas. A eso se puede imaginar, respondió la Duquesa, que arrepentido del mal que habia hecho á la Trifuldi y companía, y á otras personas, y de las maldades que como hechicero y encantador tebia de haber comerido, quiso concluir con todos los instrumentos $\mathrm{de}$ su oficio, $\mathrm{y}$ como á principal, $y$ que mas le traia desasosegado, vagando de ticrra en ticrra, abrasó á Clavileño, que con sus abrasadas cenizas, y con el trofeo del cartel queda cterno el valor del gran Don Quixote de la Mancha. De nuevo nuevas gracias dió Don Quixote á la Duquesa, y en cenando, Don Quixote se retiró en su aposento sulo, sin consentir que nadic entrase con él á servirle : tanto sc temia de encontrar ocasioncs que le moviesen, ó forzasen á perder el honesto decoro que á su Señora Dulcinea guardaba, siempre puesta en la imaginacion la bondad de Amadis, flor y espejo de los anciantes caballeros. Cerró tras sí la puerra, y á la luz de dos vclas de cera se desnutó, y al descalzarse jó desgracia indigna de tal persona! se le soltáron, no suspiros, ni otra cosa que desacreditase la limpieza de su policía, sino hasta dos docenas de puntos de una media, que quedó hecha celosía. Alligióse en extremo el buen señor, y diera él por tencr allí un adarme de seda verde, una onza de plata, digo seda verde, porque las medias eran rerdes. Aquí exclamó Benengeli, y cscribiendo dixo : ió pobreza, pobreza! no sé yo con que razon se movió aquel gran Pocta Cordobes á llamarte dádiva santa desagradecida: yo, aunque Moro, bien sé por la comunicacion que he tenido con Christianos, que la santidad consiste en la caridad, humildad, fe, obediencia y pobreza; pero con todo eso digo, que ha de tener mucho de Dios el que se viniere á contentar con ser pobre, sino es de aquel modo de pobreza, de quien dice uno de sus mayores San- 
tos: tened todas las cosas como si no las tuviésedes, y á esto llaman pobreza de espíritu ; pero tú, segunda pobreza (que cres de la que yo hablo) :porque quieres estrellarte con los hidalgos, $y$ bien nacidos, mas que con la otra gente? ¿Porque los obligas á dar pantalia á los zapatos, y á que los botones de sus ropillas, unos sean de seda, otros de cerdas, y otros de vidro? ¿Porque sus cuellos, por la mayor parte, han de scr siempre escarolados, y no abiertos con molde? (y en esto se echara de ver cue es antiguo $\mathrm{cl}$ uso del almidon, $y$ de los cucllos abicrtos) y prosiguió : miserable del bien nacido, que va dando pistos á su honra, comiendo mal, y á puerta cerrada, haciendo hipocrita al palillo de dientes, con que sale á la calle despues de no haber comido cosa que le obligue á limpiárselos: miscrable de aquel, digo, que tiene la honra espantadiza, y picnsa que desde una legua se le descubre el remiendo del zapato, el trasudor del sombrero, la hilaza del herreruelo, y la hambre de su estómago. Todo esto se Ie renovó á Don Quixote en lia soltura de sus puntos; pero consolóse con ver que Sancho le habia dexado unas botas de camino, que pensó ponerse otro dia. Finalmente él se recostó pensativo, y pesa roso, así de la falta que Sancho le hacia, como de la inreparable desgracia de sus medias, á quien tomara los puntos, aunque fuera con seda de otra color, que es una de las mayores señales de miseria que un hidalgo puede dar en el discurso de su prolixa estrecheza. Mató las velas, hacia calor, y no podia dormir: Icvantóse del lecho, $y$ abrió un poco la ventana de una reja, que daba sobre un hermoso jardin, $y$ al abrirla sintió, y oyó que andaba, $y$ hablaba gente en el jardin: púsose á escuchar atcutamente, levantíron la voz los de abaxo, tanto que pudo oir estas razones.

No me porfies, ó Emerencia, que cante, pues sabes que descle el punto que este forastero entró en este castillo , y mis ojos le miráron, yo no sé cantar, sino llorar, quanto mas que cl sueño de mi señora tiene mas de ligero, que de pesado, $y$ no querria que nos hallase aquí por todo el tesoro del mundo : $y$ puesto caso que durmicse, y no despertase, en vano seria mi canto si duerme, y no despierta para oirle este nuevo Eneas, que ha llegado á mis regiones para dexarme ${ }^{13}$ escarnida. No des en eso, Altisidora amiga, respondiéron, que sin duda la Duquesa, y quantos hay en esta casa duermen, sino es el Señor de tu corazon, y el despertador de tu alma, porque ahora sentí que abria la ventana de la reja de su cstancia , y sin duda debe de estar despierto: canta, lastimada mia, en tono baxo y suave, al son de tu arpa, y quando la Duquesa nos sienta, le echarémos la culpa al calor que hace. No está en eso cl punto, ó Emerencia respondió la Altisidora, sino en que no querria que $\mathrm{mi}$ canto descubricse mi corazon, y fuese juzgada de los que no ticnen noticia de las fuerzas poderosas de amor, por doncella antojadiza y liviana; pero venga lo que viniere, que mas vale vergüenza en cara, que mancilla en corazon: y en esto comenzó á tocar una arpa suavísimamente. Oyendo lo qual quedó Don Quixote pasmado, porque en aquel instante se le viniéron á la memoria las infinitas aventuras, semejantes á aquella de ventanas, rejas y jardines, músicas, requiebros y desvanecimientos, que en los sus desvanecidos libros de caballerías habia leido. Luego imaginó, que alguna doncella de la Duquesa esta- 
ba dél cnamorada, y que la honestidad la forzaba á tener secreta su voluntad. Temió no le rindiese, y propuso en su pensamiento $\mathrm{cl}$ no dexarse vencer, $\mathrm{y}$ cncomendándose de todo buen ánimo, y buen talante á su Señora Dul cinea del Toboso, determinó de escuchar la música, y para dar á entender que allí estaba, dió un fingido estornudo, de que no poco se alegráron las doncellas, que otra cosa no deseaban, sino que Don Quixote las oyese. Recorrida pues, y afinada la arpa, Altisidora dió principio á este Romance:

\section{O Tii que estás en tu lecho,} entre sábanas de olanda, durmiendo á pierna tendida de la noche á la mañana.

Caballero el mas valiente.

que ha producido la Mancha, mas honesto y mas bendito que el oro fino de Arabia:

Oye á una triste doncella,

bien crecida, y mal lograda, que en la luz de tus dos soles se siente abrasar el alma.

Tí buscas tus aventuras, y agenas desdichas hallas, das las feridas, y niegas cl remedio de sanarlas.

Dime, valeroso joven,

que Dios prospere tus ansias, ¿si te criaste en la Libia, ó cn las Montañas de Jaca?

PARTEII. CAPITULO XIIV. ¿Si sierpes te dicron leche? isi a dicha fuéron tus amas la aspereza de las selvas, $y$ el horror de las montanias? Muy bien puede Dulcinea, doncella rolliza y sana, preciarse de que ha rendido á una tigre, y fiera brava.

Por esto será famosa

desde Henáres á Xarama, desde el Tajo á Manzanáres, desde Pisuerga hasta Arlanza. Trocárame yo por ella,

$y$ diera encima una saya de las mas gajadas mias, que de oro la adornan franjas. ${ }^{\circ}$ quien se viera en tus brazos, o si no junto á tu cama, rascándote la cabeza, y matándote la caspa! Mucho pido, y $n$ soy digna de merced tan senalada: los pies quisiera tracrte, que à una humildo esto le basta. ;O que de cófias to diera, que de escarpines de plata, que de calzas de damasco, que de herreruelos de olanda! i.ue de finisimas perlas, cada qual como una agalla. que á no tener companieras, 
No mires de tu Tarpeya

este incendio que me abrasa,

Neron Manchego del mundo,

ni le avives con tu saña.

Niña soy, pulcela ticma,

mi cdad de quince no pasa,

catorce tengo y tres meses,

te juro en Dios y en mi ánima.

No soy renca, ni soy coxa,

ni tengo nada de manca,

los cabellos como lirios,

que en pie por el suelo arrastran.

$Y$ aunque es mi boca aguilina,

y la nariz algo chata,

ser mis dientes de topacios,

mi belleza al cielo ensalza.

Mi voz yaves, si me escuchas,

que á la gue es mas dulce iguala. $y$ soy de disposicion

algo ménos que mediana.

Estas, $y$ otras gracias mias,

son despojos de tu aljaba,

desta casa soy doncella,

y Altisidora me llaman.

Aquí dió fin el canto de la mal ferida Altisidora, y comenzó el asombro del requerido Don Quixote, el qual dando un gran suspiro, dixo entre sí: ¡Que tengo de ser tan desdichado andante, que no ha de haber doncella que me mire, que de mí no se enamore! ¿Que tenga de ser
PARTE II. CAPÍTUIO XLIV.

$8_{5}$ tan corta de ventura la sin par Dulcinea del Toboso, que no la han de dexar á solas gozar de la incomparable firmeza mia! :Que la quereis, Reynas? ¿A A que la perseguis, Emperatrices? ¿ Para que la acosais, doncellas de á catorce á quince años? Dexad, dexad á la miserable que triunfe, se goce y ufane con la suerte que amor quiso darle en rendirle mi corazon, $y$ entregarle mi almi. Mirad, caterva enamorada, que para sola Dulcinea soy de masa $y$ de alfenique, y para todas las demas soy de pedernal : para ella soy micl, y para vosotras acíbar: para mí sola Dulcinea es la hermosia, la discreta, la honesta, la gallarda y la bien nacida, y las demas las feas, las necias, las livianas, y las de peor linage: para ser yo suyo, y no de otra alguna, me arrojó la naturaleza al mundo: llore, ó cante Altisidora, descspérese Madama, por quicn me aporréaron en el castillo del Moro encantado, que yo tengo de ser de Dulcinea cocido, ó asado, limpio, bien criado y honesto, á pesar de todas las potestades hechiccras de la tierra : y con esto cerró de golpe la ventana, y despechado y pesaroso, como si le hubicra acontecido alguna gran desgracia, se acostó en su lecho, donde le dexarémos por ahora, porque nos cstá llamando el gran Sancho Panza, que quiere dar principio á su famoso Gobierno.

\section{CAPITULO XLV.}

De como el gran Sancho Panza tomó la posesion de sue Insular y del modo que comenzó á gobernar.

$\mathbf{O}_{\mathrm{O}}$ mundo, ojo del ciclo, meneo dulce de las cantimploras! 
DON QUIXOTE DE LA MANCHA padre de la poesía, inventor de la música, tú que siempre sales, $y$ aunque lo parece, nunca te pones. A ti digo, ó Sol, con cuya ayuda cl hombre engendra al hom bre: á ti digo, que me favorezcas, y alumbres la cscuridad de mi ingenio, para que pueda discurrir por sus puntos en la narracion del Gobierno del gran Sancho Panza, que sin ti yo me siento tibio, desmazalado y confuso.

Digo pues, que con todo su acompañamiento llegó Sancho á un Lugar de hasta mil vecinos, que era de los mejores que el Duque tenia. Diéronle á cntender, que se llamaba Ia Ínsula Barataria, ó ya porque el Lugar se llamaba Baratario, ó ya por el barato con que se le habia dado el Gobierno. Al llegar á las puertas de la villa, que cra cercada, salió el Regimiento del pucblo á recebirle, tocáron las campanas, y todos los vecinos diéron muestras de general alegría, y con mucha pompa le lleváron á la Iglesia mayor á dar gracias á Dios, y luego con algunas ridículas ceremonias le entregáron las llaves del pueblo, y le admitiéron por perpetuo Gobernador de la Insula Barataria. El trage, las barbas, la gordura y pequeñez del nuevo Gobernador tenia admirada á toda la gente que el busílis del cuento no sabia, y aun á todos los que lo sabian, que eran muchos. Finalmente en sa cándole de la Iglcsia, le lleváron á la silla del juzgado, y le sentáron en ella, y el mayordomo del Duque le dixo: es costumbre antigua en esta Insula, señor Gobernador, que el que viene á tómar posesion desta famosa Insula, está obligado á responder á una pregunta que se le hiciere, que sea algo intricada y dificultosa, de cu-
PARTE II. CAPYTULO XLV.

ya respuesta el pueblo toma, y toca el pulso del ingenio de su nuevo Gobernador, y así, ó se alegra , ó se entristece con su venida. En tanto que el mayordomo decia esto á Sancho, estaba él mirando unas grandes y muchas letras, que en la pared frontera de su silla estaban escritas, y como él no sabia leer, preguntó , que que ${ }^{\text {is }}$ eran aquellas pinturas que en aquella pared estaban. Fuéle respondido : señor, allí está escrito y notado el dia en que V. S. tomó posesion desta Ínsula, y dice el epitafio: hoy dia á tantos de tal mes, y de tal año, tomó la poscsion desta Insula el señor Don Sancho Panza, que muchos años la goce. ¿ Y á quien Ilaman Don Sancho Panza? preguntó Sancho. Á V. S. respondió el mayordomo, que en esta Insula no ha entrado otro Panza, sino el que está sentado en esa silla. Pues advertid, hermano, dixo Sancho, que yo no tengo Don, ni en todo mi linage le ha habido: Sancho Panza me llaman á secas, y Sancho se llamó mi padre, y Sancho mi agüelo, y tocos fuéron lanzas sin anadiduras de Dones, ni donas, y yo imagino, que en esta Insula debe de haber mas Dones que piedras; pcro basta, Dios me entiende, y podrá ser que si el Gobicrno me dura quatro dias, yo escarde estos Dones, que por la muchedumbre deben de enfadar como los mosquitos. Pase adelante con su pregunta el señor mayordomo, que yo responderé lo mejor que supiere, ora se entristezca, ó no se entristezca el pueblo. Á este instante entráron en el juzgado dos hombres, el uno vestido de labrador, y el otro de sastre, porque traia unas tixeras en la mano, $y$ el sastre dixo: señor Gobernador, yo y este hombre labrador venimos ante vuesa merced en razon que este buen hombre llegó á mi tien- 
da aycr, que yo con perdon de los presentes soy sastre cxâminado, que Dios sea bendito, y poniéndome un pedazo de paño en las manos, me preguntó : señor èabria en este paño harto para hacerme una caperuza? Yo tanteando el paño, le respondí que sí : él debióse de imaginar, á lo que yo imagino, é imaginé bien, que sin duda yo le queria hurtar alguna parte del paño, fundándose en su malicia, y en la mala opinion de los sastres, y replicóme, que mirase si habria para dos: adivinéle el pensamiento, y díxele, que sí, y el caballero en su dañada y primera intencion, fué añadiendo caperuzas, y yo añadiendo sies, hasta que llegamos á cinco caperuzas, y ahora cn este punto acaba de venir por ellas, yo se las doy, y no me quiere pagar la hechura, ántes me pide que le pague, ó vuelva su paño. ¿Es todo csto así, hermano? preguntó Sancho. Sí señor, respondió el hombre ; pero hágale vuesa merced que muestre las cinco caperuzas, que me ha hecho. De buena gana, respondió el sastre, y sacando encontinente la mano debaxo del herreruclo, mostró en ella cinco caperuzas puestas en las cinco cabezas de los dedos de la mano, y dixo: he aquí las cinco caperuzas que este buen hombre me pide, $y$ en Dios y en mi conciencia que no me ha quedado nada del paño, y yo daré la obra á vista de veedores del oticio. Todos los presentes se riéron de la multitud de las caperuzas, $y$ del nuevo pleyto. Sancho se puso á considerar un poco, y dixo: paréceme que en este pleyto no ha de haber largas dilaciones, sino juzgar luego á juicio de buen varon, y asi yo doy por sentencia, que el sastre pierda las hechuras, y el labrador el paño, y las caperuzas se lleven á los presos de la carcel, y no haya mas. Si la sentencia
PARTE YY. CAPÍTULO XIV.

pasada 'de la bolsa del ganadero movió á admiracion á los circunstantes, esta les provocó á risa; pero en fin se hizo lo que mandó el Gobernador, ante el qual se presentúron dos hombres ancianos, el uno traia una cañaheja por báculo, y el sin báculo dixo: scrior, á este buen hombre le presté dias ha diez escudos de oro en oro, por hacerle placer y buena obra, con condicion que me los volviese quando se los pidiese: pasúronse muchos dias sin pedírselos, por no ponerle en mayor necesidad de volvérmelos, que la que él tenia quando yo se los presté ; pero por parecerme que se descuidaba en la paga, se los he pedido una $y$ muchas veces, $y$ no solamente no me los vuclve, pero me los niega, y dice que nunca tales diez escudos le presté , y que si se los presté , que ya me los ha vuclto: yo no tengo testigos, ni del prestado, ni de la vueita, porque no me los ha vuclto : querria que rucsa merced le tomase juranento, y si jurare que me los ha vuclto, yo se los perdono para aquí y para delante de Dios. ¿Que decis vos á esto, buen viejo del búculo? dixo Sancho. A lo que dixo el vicjo: jo, señcr, conficso que me los prestó, y baxe vuesa merced esa vara, y pues él lo dexa en mi juramento, yo juraré como se los he vuelto, y pagado real y verdaderamente. Baxó el Gobernador la vara, y en tanto el vicjo del báculo dió cl búculo al otro viejo que se le tuviese en tanto que juraba, como si le cmbarazara mucho, y lucgo puso la mano en la cruz de la vara, diciendo, que cra verdad que se le habian prestado aquellos diez escudos que se le pedian, pero que él se los habia vuelto de su mano á la suya, y que por no caer en cllo se los volvia á pedir por momentos. Viendo lo qual el gran Gobernador, rom 
preguntó al acreedor, que respontia a lo que decia su a dixo, que sin duda alyuna su deudor debia de decir verdad, porque le tenia por hombre de bien, y buen christiano, y que á él se le debia de haber olvidado el como y quando se los habia vuclto, y que desde allí en adelante jamas le pidiria nadu Tornó á tomar su báculo el deudor, y baxando la cabcza, se salió del juzgado. Visto lo quai Sancho, y que sin mas, ni mas se iba, y viendo tambien la paciencia del demandante, inclinó la cabeza sobre el pecho, $y$ poniéndose el índice de la mano derecha sobre las ccjas, y las narices, estuvo como pensativo un pequeño espacio, y luego alzó la cabeza, y mandó que le llamasen al vicjo del báculo, que ya se habia ido. Truxéronsele, y cn viéndole Sincho, le dixo: dadme, buen hombre, ese búculo, que le he menester. De muy buena gana, respondió el viejo : hele aquí, scñor, y púsosele en la mano: tomóle Sancho, y dándosele al otro viejo, le dixo: andad con Dios, que ya vais pagado. ¿Yo, señor? respondió ci viejo ¿ pues vale esta caniahcja diez escudos de oro: Sí, dixo cl Gobernador, ó si no, yo soy el mayor porro del mundo, y alio. ra se verá si tengo yo caletre para gobernar todo un Rcyno, y mandó que allí delante de todos se rompiesc y abriese la caña. Hízose así, y en el corazon della halláron dicz escudos en oro. Qucdáron todos admirados, y tuviéron is su Gobernador por un nucvo Salomon. Preguntúronle de donde habia colegido que en aquella caniaheja estaban aquellos diez escudos, y respondió, que de haberle visto dar el viejo que juraba á su contrario aquel báculo en tanto que hacia el juramento, y jurar que se los habia dado real y verdaderamente, y que en acabando de jurar le tornó á pedir el báculo, le vino á la imaginacion, que dentro dél estaba la paga de lo cuc pedian : de donde se podia colegir, que los que gobiernan, aunque scan unos tontos, tal vez los encamina Dios en sus juicios, y mas que él habia oido contar otro caso como aquel al Cura de su Lugar, y que él tenia tan gran memoria, que á no olvidársele todo aquello de que queria acordarse, no hubiera tal memoria en toda la Ínsula. Finalmente cl un viejo corrido, y el otro pagado, se fuéron, $\mathrm{y}$ los presentes quedáron admirados, $\mathrm{y}$ el que escribia las palabras, hechos y movimientos de Sancho, no acababa de determinarse, si le tendria y pondria por tonto, ó por discreto. Luego acabado este pleyto, entró en el juzgado una muger asida fuertemente de un hombre, vestido de ganadero rico, la qual venia dando grandes voces, diciendo : justicia, señor Goberrador, justicia, y si no la hallo en la ticrra, la iré á buscar al ciclo. Señor Gobernador de mi ánima, este mal hombre me ha cogido en la mitad dese campo, y se ha aprovechado de mi cuerpo, como si fuera trapo mal lavado, y desdichada de mí me ha llevado lo que yo tenia guardado mas de veinte y tres años ha, defendiéndolo de Moros y Christianos, de naturales y extrangeros, y yo sicmpre dura como un alcornoque, conservándome entera, como la salamanquesa en el fuego, ó como la lana entre las zarzas, para que este buen hombre llegase ahora con sus manos limpias á manosearme. Aun eso está por averiguar, si ticne limpias, ó no las manos este galan, dixo Sancho, y volviéndose al hombre, le dixo, que decia, y respondia á la querella de aquella muger, el qual todo turbado respondió : señores, yo soy un pobre ganadero de gana- 
de cerda, y esta manana salia deste Lugar de vender con perdon sea dicho, quatro puercos, que me llevíron de alcabalas y socalinas poco ménos de lo que ellos valian : volvíame á mi aldea, topé en el camino á esta buena ducña, $y$ el diablo, que todo lo añasca, y todo lo cuece, hizo que yogúsemos juntos, paguéle lo soficiente, y clla mal contenta asio de mí, y no me ha dexado hasta tracrme á este puesto: dice que la forcé, y miente para el juramento que hago, ó pienso hacer, y esta es toda la verdad, sin faltar meaja. Entónces el Gobernador le preguntó, si traia consigo algun dinero en plata : é dixo, que hasta veinte ducados tenia en el seno en una bolsa de cucro. Mandó que la sacase, y se la entregase asi como estaba á la quercllante : él lo hizo temblando tomóla la muger, $y$ haciendo mil zalemas á todos, y rogando á Dios por la vida, y salud del scinor Gobernador, que así miraba por las huérfanas menesterosas, $\mathrm{y}$ doncellas, y con esto se salió del juzgado, llevando la bolsa asida con entrúmbas manos, aunque primero miró si cra de plata Ia moneda que llevaba dentro. Apénas salió quando Sancho dixo al ganadero, que ya se ie salraban las lágrimas, y los ojos y el corazon se iban tras su bolsa: buen hombre, id tras aquella muger, y quitadle la bolsa, aunque no quiera, $y$ volved aquí con ella : y no lo dixo á tonto, ni is sordo, porque luero partio como un rayo, y fué á lo que se le mandaba. Todos los presentes estaban suspensos, esperando cl fin de aquel pleyto, $y \mathrm{dc}$ alli a poco volviéron cl hombre, y la muger, mas asidos y afcrractos que la vez primera: clla la saya levantada $y$ en cl recazo puesta la bolsa, y el hombre pugnando por quitársela, mas no era posible, segun la muger la defen- dia , la qual daba voces, diciendo : justicia de Dios, del mundo, mire vuesa merced, scñor Gobernador, la poca vergüenza, y el poco temor deste desalmado, que en mitad de poblado, $y$ en mitad de la calle me ha querido quitar la bolsa que vuesa merced mandó darme. Y haosla quitaclo: preguntó el Gobernador. ¿Como quitar respondió la muger, ánes me dexara yo quitar la vida, que me quiten la bolsa : bonita es la niña, orros gatos me han de echar á las barbas, que no este desventurado, y asqueroso: tenazas y martillos, mazos y escoplos no serín bastantes á sacírmela de las uñas, ni aun garras de leones, ántes el ánima de en mitad en mitad de las carnes. Ella tiene razon, dixo el hombre, y yo me doy por rendido $y$ sin fucrzas, $y$ confieso, que las mias no son bastantes para quitúrscla: y dexola. Entónces el Gobernador dixo á la muger: mostrad, honrada y valiente, esa bolsa : clla se la dió luego, y cl Gobernator se la rolvió al hombre, y dixo á la estorzada, y no forzada: hermana mia, si el mismo aliento, y valor que habeis mostrado para defender esta bolsal, le mostrárades, y aun la mitad ménos para defender vuestro cuerpo, las fuerzas de Hércules no os hicicran fucrza: andad con Dios, y mucho de cnhora mala, y no pareis en toda esta Ínsula, ni en seis leguas á la redonda, sopena de docientos azores: andad luero, digo, churrillera, desvergonzada, y embaydora. Espantóse la muger, y fuese cabizbaxa, y mal contenta, y el Gobernador dixo al hombre: buen hombre, andad con Dios á vuestro Lugarar con vuestro dinero, y de aquíadelante, si no le quereis perder, procurad que no os venga en voluntad de yogar con nadie. El hombre le dió las gracias lo peor que supn, y fuese, y los circunstantes 
quedíron admirados de nuevo de los juicios, y sentencias de su nuevo Gobernador. Todo lo qual notado de su coronista, fué luego escrito al Duque, que con gran deseo lo estabo esperando: y quédese aquí el buen Sancho, que es mucha la priesa que nos da su amo, alborozado con la música de Altisidora.

\section{CAPITULO XLVI.}

Del temeroso espanto cencerril y gatuno, que recibio Don Duixote en el discurso de los amores de la

$$
\text { enamorada Altisidora. }
$$

Dexámos al gran Don Quixote envuelto cn los pensamientos que le habia causado la música de la cnamorada doncella Altisidora. Acostóse con ellos, y como si fueran pulgas, no le dexáron dormir, ni sosegar un punto,$y$ juntábansele los que le faltaban de sus medias ; pero como es ligero el tiempo, y no hay barranco que le dctenga, corrió caballero en las horas, y con mucha presteza llegó la de la mañana. Lo qual visto por Don Quixote, dexó las blandas plumas, y no nada perczoso se vistió su acamuzado vestido, y se calzó sus botas de camino por encubrir la desgracia de sus medias. Arrojóse encima su manton de escarlata, y púsose en la cabcza una montera de terciopelo verde, guarnecida de pasamanos de plata: colgó cl tahalí de sus hombros, con su buena y tajadora espada : asió un gran rosario, que consigo contino traia, y con gran prosopopeya y contonco salió á la antesala, donde el Duque y la Duquesa estaban ya vestidos, $y$ como esperándole $\mathrm{y}$ al pasar por una galería estaban aposta esperándole Alrisidora y la
PARTE. II. CAPATULO XIVT.

otra doncella su amiga, y así como Altisidora vió á Don Quixote, fingió desmayarse, y su amiga la recogió en sus fallias, y con gran presteza la iba á desabrochar el pecho. Don Quixote que lo vió, llegándose á cllas, dixo: ya sé yo de que proceden estos accidentes. No sé yo de que, respondió la amiga, porque Altisidora es la donculla mas sana de toda esta casa, y yo nunca la he sentido un ay en quanto ha que la conozco : que mal hayan quantos caballeros andantes hay en cl mundo, si es que todos son desagradecidos: váyasc vuesa merced, seİor Don Quixote, que no volverá en sí esta pobre niña en tanto que vuesa merced aquí estuvicre. Á lo que respondió Don Quixote : haga vuesa merced, scñora, que se me ponga un laud esta noche en $\mathrm{mi}$ aposento, que yo consolaré lo mejor que pudicre á esta lastimada doncella, que en los principios amorosos, los desengaños prestos suelen ser remedios calificados : y con esto se fué, porque no fuese notado de los que allí le viesen. No se hulo bien apurtado, quando volviendo en sí la desmayada AItisidora, dixo á su compañera : menester será, que se le ponga el laud, que sin duda Don Quixote quiere darnos música, y no será mala, siendo suya. Fuéron lucgo á dar cuenta á la Duquesa de lo que pasaba, y del laud que pedia Don Quixote, y ella alegre sobre modo concertó con el Duque, y con sus doncclias de haccrle una burla, que fucse mas risucña, que dañosa, y con mucho contento esperaban la noche, que se vino tan apriesa, como se habia venido el dia, cl qual pasáron los Duques en sabrosas pláticas con Don Quixote : y la Duquesa aquel dia, real y verdaderamente despachó á un page suyo, que habia hecho en la selva la figura encan- 
tada de Dulcinea, á Tcresa lanza, con la carta de su marido Sancho Panza, y con el lio de ropa que habia dexado para que se le enviase, encargándole le truxese buena relacion de todo lo que con clla pasase. Hecho esto, y llegadas las once horas de la noche, halló Don Quixote una vihuela en su aposento: templóla, abrió la reja, y sintió que andaba gente en "el jardin, y habiendo recorrido los trastes de la vihuela, $\mathrm{y}$ afinándola lo mejor que supo, escupió, y remondóse el pecho, y lucgo con una voz ronquilla, aunque entonada, cantó el siquiente Romance, que él mismo aquel dia habia compuesto:

Suelon las fuerzas de amor sacar de quicio á las almas, tomando por instrumento la ociosidad descuidada. Suele el coser y el labrar, y'el estar siempre ocupada, ser antidoto al veneno do las amorosas ansias.

Las doncellas recogidats, que aspiran á ser casadas, la honestidad es la dote $y$ voz de sus alabanzas.

Los andantes caballeros, y los que en la Corte andan, requicbranse con las libres, con las honestas se casan.

Hay amores do levante, que entre huléspedes se tratan, que llegan presto al poniente. porgue en el partir se acaban.
El amor recien venido,

que hoy llegó, y se va mañana, las imágines no dexa

bien imprisas en el alma.

Pintura sobre pintura,

ni se muestra, ni seniala,

$y$ do hay primera belleza,

la segunda no hace baza.

Dulcinea del Toboso

del alma en la tabla rasa tengo pintada de modo,

que es imposible borrarla.

Ia firmeza en los amantes

es la parte mas preciada, por quicu hace amor milagyos,

$y$ asimesmo los levanta.

Aquíllegaba Don Quixote de su canto, á quien estaban escuchando el Duque y la Duquesa, Altisidora y cas toda la cente del castillo quando de improviso desde encima de un corredor, que sobre la reja de Don Quixote á plomo caia, descolgáron un cordel, donde venian mas de cien cencerros asidos, y luego tras cllos derramáron un gran saco de gatos, que asimismo traian cencerros menores atados á las colas. Fué tan grande el ruido de los cencerros y el mayar de los gatos, que aunque los Duques habian sido inventores de la burla, todavía les sobresaltó , y temeroso Don Quixote, quedó pasmado, y quiso la sucrte que dos, ó tres gatos se entráron por la reja de su estancia, y dando de una partc á otra, parccia que una legion de diablos andaba en ella. Apagáron las

$$
\text { том. Jv. }
$$


velas que en el aposento ardian, $y$ andaban buscando por do escaparse El descolgar y subir del cordel de los grandes cencerros no cesaba: la mayor parte de la gente del castillo, que no sabia la verdad del caso, estabu suppensa y admirata. Levantóse Don Quixote en pie, y poniendo mano á la espada comenzó á tirar estociadals por la reja y á decir á grandes roces: afuera, malignos encancadores, afucra, canalla hechiceresca, que yo ooy Don Quixote de la Mancha contra quien no valen, ni ticnen fuerza vuestras malas intenciones: $y$ volviéndose al los gat tos, que andaban por el aposento, les tire muchas cuchilliadas : cllos acudiéron á la reja, yo por allí sc salicron, aunque uno viéniós tan acosado de las cuchillatias do Don Quixote, le saltó al rostro, y le asió de lar narices con las unas y los dientes, por cuyo dolor bon Quisote comenzó a dar los mayores gritos que pudo. (O) yento lo qual el Duque y la Duguesa, $y$ considerando lo que podia ser con mucha presteza acudiéron á su cstancia, y abriendo con llare macstra, viéron al pobre caballero pugnando con todas sus fuerzas por arrancar el gato de su rostro. lintráron con luecs, y vicron la desigual pelca : acudió el Duque á despartirla, y Don Quixote dixo á voces: no me le quite nadie, déxenme mano á mano con este demonio, con este hechicero, con este encantador, que yo le daré á entender de mí á él quien es Don Quixute de la Mancha. Pero el gato no curándose destas amenazas, gruñia, y apretaba. Mas en fin cl Dut que se le desarraigó, y le echó por la reja: quedó Don Quixote acribado el rostro, y no muy sanas las marices, aunque muy despechato, porque no le habian dexado fenecer la batalla que tan trabada tenia con aquel malan- drin encantador. Hiciéron tracr aceyte de aparicio, y la misma Altisidora con sus blanquísimas manos le puso unas vendas por todo lo herido, $\mathrm{y}$ al ponérselas con voz baxa le dixo: todas estas malandanzas te suceden, empedernido caballero, por el pecado de tu dureza, $y$ pertinacia , y plega á Dios que se le olvide á Sancho ${ }^{18}$ tu escudero el azotarse, porque nunca salga de su encanto esta tan amada tuya Dulcinea, ni tú la goces, ni llegues á tálamo con clla, aloménos viviendo yo, que te adoro. A todo esto no respondió Don Quixote otra palabra, sino fué dar un profundo suspiro, y luego se tendió en su lecho, agradeciendo á los Duques la merced, no porque él tenia temor de aquella canalla gatesca encantadora, y cencerruna, sino porque habia conocido la buena intencion con que habian venido á socorrerle. Los Duques le dexáron sosegar, y se fuéron pesarosos del mal suceso de la burla, que no creyéron que tan pesada y costosa le saliera á Don Quixote aquella aventura, que le costó cinco dias de cncerramiento y de cama, donde le sucedió otra aventura mas gustosa que la pasada, la qual no quiere su historiador contar ahora, por acudir á Sancho Pan$z a$, que andaba muy solícito y muy gracioso en su Gobierno.

$$
\text { CAPÍTULO XLVII. }
$$

Donde se prosigue como se portaba Sancho Panza

Cuenta la historia, que desde el juzgado lleváron á Sancho Panza á un suntuoso Palacio, adonde en una gran sala estaba puesta una Real y limpísima mesa, y así como Sancho entró en la sala, sonáron chirimías, y saliéron

$$
\begin{aligned}
& \text { rom. iv. } \\
& \text { sij }
\end{aligned}
$$


100

DON QUIXOTE DE IA MANCHA

quatro pages á darle aguamános, que Sancho recibió con mucha gravedad: cesó la música, sentóse Sancho á la cabecera de la mesa, porque no habia mas de aquel asiento,$y$ no otro scrvicio en toda ella. Púsose á su lado en pie un personage, que despues mostró ser médico, con una varilla de ballena en la mano: levantúron una riquísima y blanca tohalia, con que estaban cubiertas las frutas y mucha diversidad de platos de diversos manjares. Uno que parecia estudiante echó la bendicion, y un page puso un babador randado á Sancho: otro que hacia cl oficio de maestresala llegó un plato de fruta delante; pe ro apćnas hubo comido un bocado, quando el de la varilla tocando con ella en el plato, se le quitáron de delante con grandísima celeridad; pero el maestresala le llegó otro de otro manjar. Iba á probarle Sancho ; pero ántes que llegase á él, ni le gustase, ya la varilla habia tocado en él, y un page alzádole con tanta presteza como el de la fruta. Visto lo qual por Sancho, quedó suspenso , y mirando á todos, preguntó si se habia de comer aquella comida como juego de Macsecoral. Á lo qual respondió el de la vara : no se ha de comer, scñor Gobernador, sino como es uso y costumbre en las otras Insulas donde hay Gobernadores. Yo, señor, soy médico, y estoy asalariado en esta Ínsula para serlo de los Gobernadores della, y miro por su salud mucho mas que por la mia, estudiando de noche y de dia, y tanteando la complexîon del Gobernador para acertar á curarle, quando cayere enfermo, y lo principal que hago es asistir á sus comidas y cenas, y á dexarle comer de lo que me parece que le conviene, y á quitarle lo que imagino que le ha de hacer daño, y ser nocivo al estómago, y así

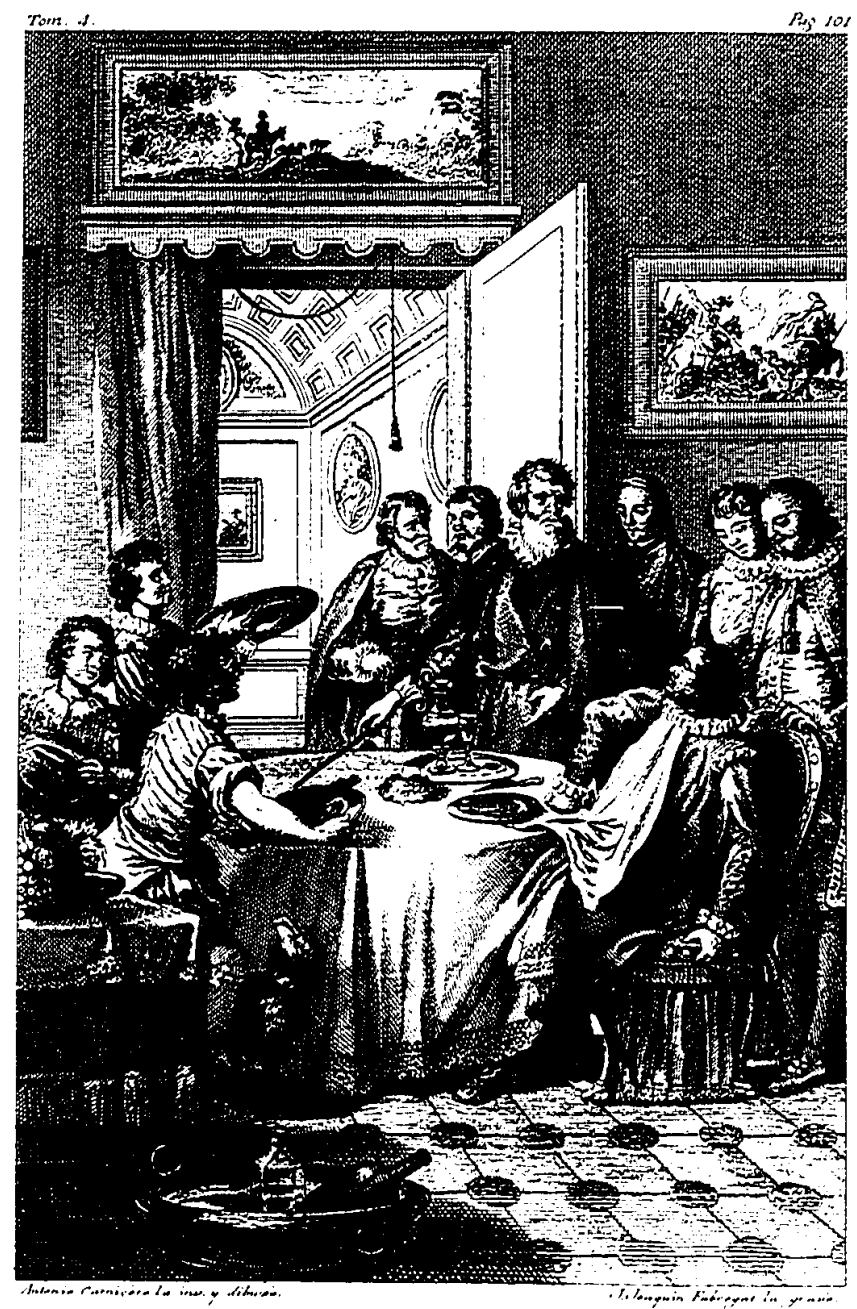


PARTEIY. CAPfTULO XIVII.

mandé quitar el plato de la fruta, por ser demasiadamente húmeda, y el plato del otro manjar tambien le mandé quitar, por ser demasiadamente caliente, $y$ tener muchas especias, que acrecientan la sed, $y$ el que mucho bebe, mata y consume el húmedo radical, donde consiste la vida. Desa manera aquel plato de perdices que están allí asadas, y á mi parecer bien sazonadas, no me harán algun daño. Á lo que el médico respondió: esas no comerá el señor Gobernador en tanto que yo tuviere vida. ¿Pues porque ? dixo Sancho. $\mathrm{Y}$ el médico respondió : porque nuestro maestro Hipócrates, norte y luz de la medicina, en un aforismo suyo dice : omnis saturatio mala, perdix autem pessima. Quiere decir : toda hartazga es mala pero la de las perdices malísima. Si eso es así, dixo Sancho, vea el señor Doctor de quantos manjares hay en esta mesa, qual me hará mas provecho, $y$ qual ménos dano, y déxeme comer dél, sin que me le apalée, porque por vida del Gobernador, y así Dios me la dexe gozar, que me muero de hambre, y el negarme la comida, aunque le pese al scńor Doctor, y él mas me diga, ántes será quitarme la vida, que aumentármela. Vuesa merced tiene razon, señor Gobernador, respondió el médico, y así es mi parecer, que vuesa merced no coma de aquellos conejos guisados que alli estan, porque es manjar peliagudo: de aquella ternera, si no fuera asada, y en adobo, aun se pudiera probar, pero no hay para que. Y Sancho dixo: aquel platonazo que está mas adelante vahando, me parece que es olla podrida, que por la diversidad de cosas que en las tales ollas podridas hay, no podré dexar de topar con alguna que me sea de gusto y de provecho. Absit, dixo el médico, vaya léjos de 
PARTE II CAPITULO XLVIT.

nosotros tan mal pensamiento : no hay cosa en el mundo de peor mantenimiento que una olla podrida: allá las ollas podridas para los Canónigos, ó para los Retores de Cole gios, ó para las bodas labradorescas, y déxennos libres las mesas de los Gobernadores, donde ha de asistir todo primor y toda atildadura: $y$ la razon es, porque siempre, $y$ á do quiera, $y$ de quien quiera son mas estimadas las medicinas simples, que las compuestas, porque en las simples no se puede errar, y en las compuestas sí, alterando la cantidad de las cosas de que son compuestas: mes lo que yo sé que ha de comer el señor Gobernador ahora, para conservar su salud y corroborarla, es un ciento de canutillos de suplicaciones, $y$ unas tajadicas subriles de carne de membrillo, que le asienten el estómago, y le ayuden á la digestion. Oyendo esto Sancho, se arrimó sobre el espaldar de la silla y miró de hito en hito al tal médico, $y$ con voz grave le preguntó como se llamaba, y donde habia estudiado. Á lo que él respondió : yo, senor Gobernador, me llamo el Doctor Pedro Recio de Agüero, y soy natural de un Lugar llamado Tirreafuera, que está entre Caraqüel y Almodóbar del Campo á la mano derecha, y tengo el grado de Doctor por la Universidad de Osuna. A lo que respondió Sancho, todo encendido en cólera: pues, señor Doctor Pedro Recio de mal agüero, natural de Tirteafuera, Lugar que está á la derecha mano como ramos de Caraquiel á Almodóbar del Campo, graduado en Osuna, quíteseme lucgo de delante, si no, voto al sol, que tome un garrote, y que á garrotazos, comenzando por él, no me ha de quedar médico en toda la Insula, aloménos de aquellos que yo entienda que son ignorantes, que á los médicos sabios, pruden- tes y discretos, los pondré sobre mi cabcza, y los honraré como á personas divinas: y vuelvo á decir, que se me vaya Pedro Recio de aquí, si no tomaré esta silla donde estoy sentado, y se la estrellaré en la cabeza, y pidánmelo en residencia, que yo me descargaré con decir, que hice servicio á Dios en matar á un mal médico, verdugo de la República, y denme de comer, ó si no túmense su Gobierno, que oficio que no da de comer á su ducrio, no vale dos habas. Alborotóse el Doctor, viendo tan cólerico al Gobernador, y quiso hacer tirteafuera de la sala, sino que en aquel instante sonó una corncta de posta en la calle, y asomándose el maestresala á la ventana, volvió dicicndo : correo viene del Duque mi señor, algun despacho debe de tracr de importancia. Entró el correo sudando y asustado, y sacando un pliego del seno, le puso en las manos del Gobernador, y Sancho le puso en las del mayortomo, á quien mandó leyese el sobrescrito, que decia así: $A$ Don Sancho $P^{2}$ anza, Gobirnador de la Insula Barataria, en su propia mano, ó en las de sie secretario. Oyendo lo qual Sancho, dixo ¿quien es aquí mi secretario? y uno de los que presentes estaban, respondió : yo, señor, porque sé leer y escribir, $y$ soy Vizcaino. Con esa añadidura, dixo Sancho, bien podeis ser secretario del mismo Emperador: abrid ese pliego, y mirad lo que dice. Hízolo así el recien nacido secretario, $y$ habiendo leido to que decia , dixo, que era negocio para tratarle á solas. Mandó Sancho despejar la sala, y que no quedasen en ella sino el mayordomo y el maestresala, y los demas y el médico se fućron : y luego el secretario leyó la carta, que así decia : 
IO4 DON OUIYOTE DR IA MAYCHA

A mi noticia ha llegado, señor. Don Sancho Panza, gue unos enemigos mios, y desa Insula la han de dar un asalto furioso, no se que noche : conviene velar $y$ estar alerta, porque no lo tomen desapercebido. Sétambiun por espias verdaderas, que han entrado en ese Lugar quatro personas disfrazadas para quitaros la vida porque se temen de vulestro ingenio : abrid of ojo. y mirad quien llega á hablaros, y no comais di cosa gue os presentaren. Yo tendre cuidado de socorréros, si os vieredes en trabajo, $y$ en todo haritis como se espera de vuestro entendimiento. Deste Lugar á diez $y$ seis de Agosto, á lass quatro de la mañana. Vutestro amigo el Dugue.

Quedó atónito Sancho, y mostráron quedarlo asimismo los circunstantes, y volviéndose al milyordomo le dixo: lo que agora se ha de hacer, $y$ ha de ser luego, es meter en un calabozo al Doctor Recio, porque si alguno me ha de matar hade ser él, y de muerte adminícula y pésima, como es la de la hambre. Tambien, dixo el maestresala, me parece á mí, que vuesa merced no coma de todo lo que está en esta mesa, porque lo han presentado unas Monjas, y como sucle decirse, detras de la cruz está el diablo. No lo nicgo, respondió Sancho, y por ahora denme un pedazo de pan, y obra de quatro libras de uvas, que en ellas no podrú venir veneno, porque en efecto no puedo pasar sin comer: y si cs que hemos de estar prontos para estas batallas que nos amenazan, menester serí estar bien mantenidos, porque tripas llevan corazon, que no corazon tripas : y vos, secretario, responded al Duque mi señor, y decidle, que se cumplirá lo que manda, comn lo inanda sin faltar
PARTE I1. CAPÍTULO XIVII. TO5 punto : y dareis de mi parte un besamanos á mi señora la Duquesa, y que le suplico no se le olvide de enviar con un propio mi carta y mi lio á mi muger Teresa Panza, que en ello rccibiré mucha merced, $y$ tendré cuiclado de escribirla con todo lo que mis fucrzas alcanzaren: y de camino podeis encaxar un besamanos á mi señor Don Quixote de la Mancha, porque vea que soy pan agradecido: y vos como buen secretario", y como buen Vizcaino podeis añadir todo lo que quisiéredes y mas viniere á cuento: y úlcense estos manteles, y denne á mí de comer, que yo me avendré con quantas espías y matadores y encantadores vinicren sobre mi y sobre mi Insula. En esto entró un page, y dixo : aquí está un labrador negociante, que quicre hablar á Vuestra Scñoría en un negocio, segun él dice, de mucha importancia. Extraño caso es este, dixo Sancho, destos negociantes ics posible que sean tan necios, que no echen de ver, que semejantes horas como cstas no son en las que han de venir á negociar? ¿ Por ventura los que gobernamos, los que somos Jucces, no somos hombres de carne y de hueso, y que es menester que nos dexen descansar el ticmpo que la necesidad pide, sino que quieren que seamos hechos de piedra mármol? Por Dios, y en mi conciencia, que si me dura el Gobierno (que no durará segun se me trasluce) que yo ponga en pretina á mas de un negociante. Agora decid á ese buen hombre que entre; pero adviértase primero no sea alguno de los espías , ó matador mio. No señor, respondió el page, porque parece una alma de cántaro, y yo sé poco, ó ćl es tan bueno como el bucn pan. No hay que temer, dixo el mayordomo, que aquí estámos todos. ¿'Seria posible, dixo Sancho, maesтом. $1 \mathrm{k}$ 
tresala, que agora que no está aquí el Doctor Pedro Recio, que comiese yo alguna cosa de peso y de sustancia, aunque fuese un pedazo de pan, y una cebolla? Esta noche á la cena se satisfarí la falta de la comida, y quedará V.S. satisfecho y pagado, dixo el maestresala. Dios lo haga, respondió Sancho, y en csto entró el labrador, que era de muy buena presencia, y de mil leguas se le echaba de ver que era bueno y buena alma. Lo primcro que dixo fué : ¿quien es aquí cl señor Gobernador? Quien ha de ser, respondió el secretario, sino el que está sentado en la silla. Humillome pucs á su presencia, dixo el labrador, y poniéndose de rodillas, le pidió la mano para besárscla. Negósela Sancho, y mandó que se levantase y dixese lo que quisiese. Hizolo así el la brador, y luego dixo : yo, señor, soy labrador, natural de Miguel Turra, un Lugar que está dos leguas de Ciudad Real. ¿Orro Tirteafuera tenemos? dixo Suncho: decid, hermano, que lo que yo os sé decir, es, que sé muy bien á Miguel Turra, y que no está muy léjos de mi pueblo. Es pues el caso, señor, prosiguió el labrador, que yo por la miscricordia de Dios soy casado en paz, y en haz de la Santa Iylesia Católica Romana, tengo dos hijos estudiantes, que el menor cstudia para Bachiller, y cl mayor para Licenciado: soy viudo, porque se murió mi muger, ó por mejor decir, me la mató un mal médico, que la purgó estando preñada, y si Dios fucra servido que salicra á luz el parto , y fuera hijo, yo le pusiera á estudiar para Doctor, porque no tuvicra invidia á sus hermanos el Bachiller y el Licenciado. De modo, dixo Sancho, que si vuestra muger no se hubiera muerto, ó la hubieran muerto, vos no fuérades agora viudo. No scñor, en nin- guna manera, respondió el labrador. Medrados estamos, replicó Sancho: adelante, hermano, que es hora de dormir, mas que de negociar. Digo pues, dixo el labrador, que este mi hijo, que ha de ser Bachiller, se enamoró en el mesmo pueblo de una doncella, llamada Clara Perlerina, hija de Andres Perlerino, labrador riquísimo: y estc nombre de Perlerines no les viene de abolengo, ni otra alcurnia, sino porque todos los deste linage son perláticos, y por mejorar el nombre los llaman Perlerines, aunque si va á decir la verdad, la doncella es como una perla oriental, y mirada por el lado derecho parece una flor del campo, por el izquierdo no tanto, porque le falta aquel ojo, que se le saltó de viruelas: y aunque los hoyos del rostro son muchos y grandes, dicen los que la quicren bien, que aquellos no son hoyos, sino sepultuzas, donde se sepultan las almas de sus amantes. Es tan limpia, que por no ensuciar la cara, trae las narices, como diccn, arremangadas, que no parce sino que van huyendo de la boca, y con todo esto parece bien por extremo, porque tiene la boca grande, y á no faltarle diez, ó doce dicntes y muelas, pudiera pasar y echar raya entre las mas bien formadas. De los labios no tengo que decir, porque son tan suriles, y delicados, que si se usaran aspar labios, pudiera hacer dellos una made$\mathrm{xa}$; pero como tienen diferente color de la que en los labios se usa comunmente, parecen milagrosos, porque son jaspeados de azul y verde y aberengenado: y perdóneme el señor Gobernador, si por tan menudo voy pintando las partes de la que al fin al fin ha de ser mi hi$\mathrm{ja}$, que la quiero bien, y no me parece mal. Pintad lo que quisiéredes, dixo Sancho, que yo me voy recreanTom. Iv. 
108

DON QUTXOTE DE LA MANCHA

do en la pintura, y si hubiera comido, no hubicra mejor postre para mí, que vuestro retrato. Eso tengo yo pos servir, respondió el labrador ; pero tiempo vendrá en que seamos, si ahora no somos, $y$ digo señor, que si pudiera pintar su gentileza, y la altura de su cuerpo, fuera cosa de admiracion; pero no puede ser, á causa de que ella está agoviada y encogida, y tiene las rodillas con la boca, y con todo eso se echa bien de ver, que si se pudiera levantar, diera con la cabeza en el techo, y ya ella hubicra dado la mano de esposa á mi Bachiller, sino que no la puede extender, que está anudada, y con todo en las uñas largas, $y$ acanaladas se muestra su bondad y buena hechura. Está bien, dixo Sancho, y haced cuenta, hermano, que ya la habeis pintado de los pies á la cabeza ; que es lo que quereis ahora? y venid al punto sin rodeos, ni callejuelas, ni retazos, ni añadiduras. Querria, señor, respondió el labrador, que vuesa merced me hiciese merced de darme una carta de favor para mi consuegro, suplicándole sea servido de que este casamiento se haga, pues no somos desiguales en los bienes de fortuna, ni cn los de la naturaleza, porque para decir la verdad, señor Gobernador, mi lijo es endemoniado, y no hay dia que tres, ó quatro veces no le atormenten los malignos espíritus: y de haber caido una vez en el fucgo, tiene el rostro arrugado como pergamino, y los ojos algo llorosos y manantiales; pero ticne una condicion de un Ángel, y sino es que se aporrea, y se da de puñadas él mesmo á sí mesmo, fuera un bendito. ¿Quereis orra cosa, buen hombre? replicó Sancho. Otra cosa querria, dixo el labrador, sino que no me atrevo á decirlo; pero vaya, que en fin no se me ha de podrir en el pecho,
PARTEII. CAPÍTULO XLVIT.

pegue, ó no pegue. Digo, señor, que querria que ruesa merced me diese trecientos, ó seiscientos ducados para ayuda de la dote de mi Bachiller : digo para ayuda de poner su casa, porque en fin han de vivir por sí, sin estar sujetos á las impertinencias de los suegros. Mirad si quereis otra cosa, dixo Sancho, y no la dexcis de decir por empacho, ni por vergüenza. No por cierto, respondió el labrador: y apénas dixo esto, quando levantándose en pie cl Gobernador, asió de la silla en que estaba sentado, y dixo: voto á tal don patan, rústico y mal mirado, que si no os apartais $y$ ascondeis luego de mi presencia, que con esta silla os rompa y abra la cabeza. Hideputa bellaco, pintor del mesmo demonio ¿y á estas horas te vienes á pedirme seiscientos ducados? :y donde los tengo yo, hediondo? :y porque te los habia de dar, aunque los tuviera, socarron y mentecato? ; y que se me da á mí de Migucl Turra, ni de todo el linage de los Pcrlerines? Va de mí, digo, si no, por vida del Duque mi señor que haga lo que tengo dicho. Tú no debes de ser de Miguel Turra, sino algun socarron, que para tentarme te ha enviado aquí el infierno. Dime desalmado, aun no ha dia $y$ medio que tengo el Gobierno $y$ ya quieres que tengal sciscicntos ducados? Hizo de scñas el maestresala al labrador, que se saliese de la sala, el qual lo hizo cabizbaxo, $y$ al parecer temeroso de que el Gobernador no executase su cólera, que el bellacon supo hacer muy bien su oficio. Pero dexemos con su cólera á Sancho, y ándese la paz en el corro, y rolvamos á Don Quixote, que le dexamos vendado el rostro, y curado de las gatescas heridas, de las quales no sanó en ocho dias : en uno de los quales le sucedió lo que Cide Hamete promete de 
contar con la puntualidad, $y$ verdad que suele contar las cosas desta historia por mínimas que scan.

\section{CAPITULO XLVIII.}

De lo que le sucedió á Don Quixote con Doña Rodriguez la ducina de la Duquesa, con otros acontecimicn-

tos dignos de escritura $y$ de memoria eterna.

Ademas estaba mohino, y malencólico el mal ferido Don Quixote, vendado el rostro, y señalado, no por la mano de Dios, sino por las unas de un gato: desdichas anexas á la andante caballería. Scis dias estuvo sin salir en público, en una noche de las quales, estando despierto y desvelado, pensando en sus desgracias, $y$ en el perseguimiento de Ailtisidora, sintió que con una llave abrian la puerta de su aposento, y luego imaginó que la enamorada doncella venia para sobresaltar su honestidad, $y$ ponerle en condicion de faltar á la fe que guardar debia á su Señora Dulcinea del Toboso. No, divo, crevendo á su imaginacion (y esto con voz que pudiera ser oida) no ha de ser parte la mayor hermosura de la tierra, para que yo dexe de adorar la que tengo grabada y estampada en la mitad de mi corazon, y en lo mas cscondido de mis entrañas, ora estes, Señora mia, transformada en cebolluda labradora, ora en Ninfa del dorado Tajo, texiendo telas de oro y sirgo compuestas, ora te tenga Merlin , ó Montesínos donde ellos quisieren, que atonde quicra eres mia, $y$ á do quiera he sido yo y he de ser tuyo. El acabar estas razones, y el abrir de la puerta fué todo uno. l'úsose en pie sobre la cama, envuelto de arriba abaxo en una colcha de raso amarillo,
PARTEIY. CAPIIULO XIYIIT. II una galocha en la cabeza, $y$ el rostro $y$ los vigotes vendados, el rostro, por los aruños, los vigotes, porque no se le desmayasen y cayesen : en cl qual trage parecia la mas extraordinaria fantasma que se pudiera pensar. Clavó los ojos en la puerta, y quando esperaba ver entrar por ella á la rendida y lastimada Altisidora, vió cntrar á una reverendísima ducina con unas tocas blancas repulgadas y lucngas, tanto , que la cubrian y enmantaban desde los pics á la cabcza. Entre los dedos de la mano izquierda traia una media vela cncendida, y con la derecha se hacia sombra, porque no le diese la luz en los ojos á quien cubrian unos muy grandes antojos: venia pisando quedito, $y$ movia los pies blandamentc. Miróla Don Quixote desde su atalaya, y quando vió su adeliño, y notó su silencio, pensó que alguna bruxa, ó maga venia en aquel trage á hacer en él alguna mala fechuría, y comenzó á santiguarse con mucha priesa. Fuese llecando la vision, y quando llegó á la mitad del aposento alzó los ojos, y vió la priesa con que se estaba haciendo cruces Don Quixote, y si él quedó medroso en ver tal figura, clla quedó cspantada en ver la suya, porque así como le vió tan alto $y$ tan amarillo con la colcha, $y$ con las vendas que le desfiguraban, dió una gran voz, dicicndo: Jesus ¿que es lo que veo? y con el sobresalto se le cayó la vela de las manos, y viéndose á escúras, volvió las espaldas para irse, $\mathrm{y}$ con el miedo tropezó en sus faldas, y dió consigo una gran caida. Don Quixote temeroso comenzó á decir : conjúrote, fantasma, ó lo que eres, que me digas quicn eres, y que me digas que es lo que de mí quieres. Si eres alma en pena, dímelo, que yo haré por ti todo quanto mis fuerzas alcanzaren, porque soy 
I I 2

DON QUIXOTE DE IA MANCHA

católico christiano y amigo de hacer bien á todo el mundo, que para esto tomé la órden de la caballería andante que profeso, cuyo exercicio aun hasta hacer bien á las ánimas del purgatorio se extiende. La brumada ducńa, que oyó conjurarse, por su temor coligió el de Don Quixote, y con voz afligida y baxa le respondió : señor Don Quixote (si es que acaso vuesa merced es Don Quixote) yo no soy fantasma, ni vision, ni alma de purgatorjo, como vuesa merced debe de haber pensado, sino Doña Rodriguez, la dueña de honor de mi señora la Duquesa, que con una neccsidad, de aquellas que vuesa mereed suele remediar, á vuesa mereed vengo. Dígame, scñora Doña Rodriguez, dixo Don Quixote ; por ventura viene vucsa merced á hacer alguna tercería? porque le hago saber que no soy de provecho para nadie, mereed á la sin par belleza de mi Señora Dulcinea del Tuboso. Diso en fin, señora Doña Rodriguez, que como vuesa merced salve, y dexe á una parte todo recado amoroso, puede volver á encender su vela, y vuelva y departirémos de todo lo que mas mandare, y mas en gusto le viniere, salvando, como digo, todo incitativo melindre. : Yo recado de nadie? señor mio, respondió la dueña, mal me conoce vuesa merced : sí que aun no estoy en edad tan prolongada, que me acoja á semejantes niñerías, pues Dios loado, mi alma me tengo en las carnes, $y$ todos mis dientes $y$ muclas en la boca, amen de unos pocos que me han usurpado unos catarros, que en esta tierra de Aragon son tan ordinarios; pero espéreme vuesa merced un poco, saldré á encender mi vela, y volveré en un instante á contar mis cuitas, como á remediador de todas las del mundo, $y$ sin esperar respuesta se salió del apo-
PARTEII. CAPÍTULO XLVIIT. II sento, donde quedó Don Quixote sosegado y pensativo esperándola; pero luego le sobreviniéron mil pensamientos accrea de aquella nueva aventura, y pareciale ser mal hecho y peor pensado, ponerse en peligro de romper á su Señora la fe prometida; y decíase á sí mismo: quien sabe si el diablo, que es sutil y mañoso, querrá engañarme agrora con una dueña, lo que no ha podido con Emperatrices, Reynas, Duquesas, Marquesas, ni Condesas, que yo he oido decir muchas veces, y á muchos discretos, que si él puede, ántes os la dará roma, que aguileña, y quien sabe si esta soledad, esta ocasion y este silencio despertará mis deseos que duermen, y harán que al cabo de mis años venga á caer donde nunca he tropezado, y en casos semejantes mejor es huir que esperar la batalla: pero yo no debo de estar en mi juicio, pues tales disparates digo y pienso, que no es posible que una dueña toquiblanca, larga y antojuna pueda mover, ni levantar pensamiento lascivo en el mas desalmado pecho del mundo. :Por ventura hay dueña en la tierra, que tenga buenas carnes: ¿Por ventura hay ducña en el orbe, que dexe de ser impertinente, fruncida y melindrosa? Afuera pucs caterva dueñesca, inútil para ningun humano regalo. $\mathrm{i}$ quan bien hacia aquella Señora, de quien se dice, que tenia dos dueñas de bulto con sus antojos y almohadillas al cabo de su estrado, como que estaban labrando, y tanto le servian para la autoridad de la sala aquellas estatuas, como las ducñas verdaderas! $Y$ diciendo esto se arrojó del Iecho con intencion de cerrar la puerta , y no dexar entrar á la señora Rodriguez; mas quando la llegó á cerrar, ya la señora Rodriguez volvia, encendida una vela de cera blanca, y quando clla vió á 
II 4

DON QUTXOTE DE LA MANCHA

Don Quixote de mas cerca envuelto en la colcha, con Ias vendas, galocha, ó becoquin, temió de nuevo, y retirándose atras como dos pasos, dixo ¿estamos seguras, señor caballero? porque no tengo á muy honesta señal haberse vuesa merced levantado de su lecho. Eso mesmo es bien que yo pregunte, señora, respondió Don Quixote: $\mathrm{y}$ así pregunto si estaré yo seguro de ser acometido y forzado. ¿'De quien, ó á quien pedis, señor caballero, esa seguridad? respondió la dueña. A vos, y de vos la pido, replicó Don Quixote, porque ni yo soy de mármol, ni vos de bronce, ni ahora son las diez del dia, sino media noche, $y$ aun un poco mas, segun imagino, y en una estancia mas cerrada y secreta, que lo debio de ser la cueva donde el traidor y atrevido Eneas gozo á la hermosa y piadosa Dido. Pero dadme, señora, la ma no, que yo no quiero otra seguridad mayor, que la de mi continencia y recato, y la que ofrecen esas reverendísimas tocas : y diciendo esto, besó su derecha mano, Y la asió de la suya, que ella le dió con las mesmas ceremonias. Aquí hace Cide Hamete un paréntesis, y dice, que por Mahoma, que diera por ver ir á los dos así asidos y trabados desde la puerta al lecho la mejor almala$f_{a}$ de dos que tenia. Entróse en fin Don Quixote en su lecho, y quedóse Doña Rodriguez sentada en una silla, algo desviada de la cama, no quitándose los antojos, ni la vela. Don Quixote se acorrucó, y se cubrió todo, no dexando mas del rostro descubierto : y habiéndose los dos sosegado, el primero que rompió el silencio fué Don Quixote, diciendo: puede vuesa merced ahora, mi señora Doña Rodriguez, descoserse y desbuchar todo aquello que tiene dentro de su cuitado corazon y lastimadas entrañas,
pARTEYI. CAPITULO XLVIII

que será de mí escuchada con castos oidos, y socorrida con piadosas obras. Así lo creo yo, respondió la dueña que de la gentil y agradable presencia de vuesa merced no se podia esperar sino tan christiana respuesta. Es pues el caso, señor Don Quixote, que aunque vuesa merced me ve sentada en csta silla, y en la mitad del Reyno de Aragon, y en hábito de ducña aniquilada y asendereada, soy natural de las Asturias de Oviedo, y de linage que atraviesan por él muchos de los mejorcs de aquella Provincia ; pero mi corca sucrte, y el descuido de mis padres, que cmpobreciéron ántes de tiempo sin saber como, ni como no, me truxéron á la Corte de Madrid, donde por bien de paz y por excusar mayores desventuras, mis padres me acomodáron á servir de doncella de labor á una principal señora, y quiero hacer sabidor á ruesa merced, que en hacer vaynillas y labor blanca ningu$n a \mathrm{mc}$ ha echado el pie adelante en toda la vida. Mis padres me dexáron sirviendo, y se volviéron á su tierra, $y$ de allía pocos años se debiéron de ir al Ciclo, porque cran ademas buenos y católicos christianos: quedé huérfana, y atenida al miserable salario y á las angustiadas mercedes que á las tales criadas se suele dar en Palacio, y en este tiempo, sin que diese yo ocasion á ello, se enamoró de mí un escudero de casa, hombre ya en dias, barbudo y apersonado, y sobre todo hidalgo como el Rey, porque era Montañes. No tratámos tan secretamente nuestros amores, que no viniesen á noticia de mi señora, la qual por excusar dimes, y dirctes, nos casó en paz y en haz de la Santa Madre Iglesia Católica Romana, de cuyo matrimonio nació una hija para rematar con mi ventura, si alguna tenia, no porque yo muriese ToM. $\mathrm{iv}$. 

desde allí á poco murió mi esposo de un cierto espanto que tuvo, que á tener ahora lugar para contarle, yo sé que vuesa merced se admirara: y en esto comeno su que tiernamente, $\mathrm{y}$ dixo: perdóneme vuesa merced señ Don Quixote, que no va mas en mi mano, porque todas las veces que me acuerdo de mi mal lograło, se me arrasan los ojos de lágrimas. ¡Válame Dios $y$ con autoridad llevaba á mi señora á las ancas de una potero sa mula, negra como el mismo azabache! que entónces no se usaban coches, ni sillas, como agora dicen que se usan, y las scñoras iban á las ancas de sus cscuderos: csto aloménos no puedo dexar de contarlo, porque se note la crianza y puntualidad de mi buen marito. Al entrar de la calle de Santiago en Madrid, que es algo cstrecha, venia á salir por ella un Alcalde de Corte, con dos alouaciles delante, y así como mi buen escudero le rio vió las riendas á la mula dando señal de volver acompañarle. Mi scñora, que iba á las ancas, con voz baxa le decia que haceis desventurado, no veis que voy aquí? El Alcalde de comedido detuvo la rienda al caballo, y díxole : seguid, señor, vuestro camino, que yo soy el que debo acompañar á mi señora Doña Casilda, que así era cl nombre de mi ama. Todavía porfiaba mi marido con la gorra en la mano á quercr ir acompañando al Alcalde. Viendo lo qual mi señorn lera y cnojo, sacó un alfiler gordo, ó creo que un pun$z o n$ del estuche, y clavósele por los lomos, demanera que mi marido dió una gran voz, y torció el cucrpo dc sucrte, que dió con su señora en el suclo. Acudiéron dos lacayos suyos á levantarla, y lo mismo hizo el Alcaldo

y los alguaciles. Alborotóse la puerta de Guadalaxara digo la gente valdía que en ella cstaba. Vínose á pie mi ama , y mi marido acudió en casa de un barbero, diciendo que llevaba pasadas de parte á parte las entrañas. Divulgóse la cortesía de mi esposo, tanto, que los muchachos le corrian por las calles, y por esto, y porque él era algun tanto corto de vista, mi señora la Duquesa le despidió, de cuyo pesirr sin duda alguna tengo para mí que se le causó el mal de la mucrte. Qucdé yo viuda, y dcsamparada, $y$ con hija acuéstas, que iba creciendo en hermosura, como la espuma de la mar. Finalmentc, como yo tuviese fama de gran labrandera, mi señora la Duquesa que estaba recien casada con el Duque mi señor, quiso traerme consigo á este Reyno de Aragon , y á mi hija, ni mas ni ménos, adonde yendo dias, y viniendo dias, creció mi hija, y con ella todo el donayre del mundo : canta como una calandria, danza como el pensamiento, bayla como una perdida, lee y escribe como un macstro de escucla, y cuenta como un avariento: de su limpicza no digo nada, que el agua que corre no es mas limpia, y debe de tener agora, si mal no me acucrdo, diez y seis años, cinco meses y tres dias, uno mas á mínos. En resolucion, desta mi muchacha se cnamoró un hijo de un labrador riquísimo, que está en una aldea del Duque mi scñor, no muy léjos de aquí. En efecto no sé como, ni como no, ellos se juntáron, y debaxo de la palabra de ser su esposo burló á mi hija, y no se la quiere cumplir: y aunque el Duque mi señer lo sabe, porque yo me he quejado á él, no una, sino muclas veces, y pedídole mande que el tal labrador se case con mi hija, hace orejas de mercader, y apénas quie- 
re oirme, y es la causa, que como el padre del burlacior es tan rico, y le presta dineros, $y$ le sale por fiador de sus trampas por momentos, no le quicre descontentar, ni dar pesadumbre en ningun modo. Querria pues, señor mio, que vuesa merced tomase a cargo el deshacer este agravio, ó ya por ruegos, ó ya por armas, pues segun todo el mundo dice, vuesa merced nació en él para deshacerlos, y para enderezar los tucrtos, y amparar los miserables, y póngasele á vuesa merced por delante la horfandad de mi hija, su gentileza, su mocedad, con todas las buenas partes que he dicho que ticne, que en Dios y en mi conciencia, que de quantas doncellas ticne mi scíora, que no hay ninguna que llegue á la suela de su zapato: y que una que llaman Altisidora, que es la que tienen por mas desenvuelta y gallarda, puesta en comparacion de mi hija, no la llega con dos leguas: porque quiero que sepa vuesa merced, scñor mio, que no es todo oro lo que reluce, porque esta Altisidorilla tiene mas de presuncion, que de hermosura, y mas de desenvuelta, que de recogida : ademas, que no está muy sana, que tiene un cierto aliento cansado, que no hay sufrir cl estar junto á ella un momento, y aun mi señora la Duquesa.... Quicro callar, que se suele decir que las paredes tienen oidos. : Que tiene mi señora la Duquesa por vida mia, señora Doña Rodriguez? preguntó Don Quixote. Con ese conjuro, respondió la dueña, no puedo dexar de responder á lo que se me pregunta con toda verdad. $¿$ Ve vuesa merced, señor Don Quixote, la hermosura de mi señora la Duquesa, aquella tez de rostro, que no parece sino de una espada acicalada y tersa, aquellas dos mexillas de leche y de carmin, que en la una tiene el sol y en la otra la luna, y aquella gallardía, con que va pisando, y aun despreciando el suelo, que no parece sino que va derramando salud donde pasa? Pues sepa ruesa merced, que lo puede agradecer primero á Dios, y luego á dos fuentes que tiene en las dos piernas, por donde se desagua todo el mal humor, de quien dicen los médicos que está llena. ¿Santa María! dixo Don Quixote ay es posible que mi señora la Duquesa tenga tales desaguaderos? No lo creyera si me lo di xeran frayles descalzos; pero pues la señora Doña Rodriguez lo dice, debe de ser así; pero tales fuentes, $y$ en tales lugares no deben de manar humor, sino ámbar líquido. Verdadcramente que ahora acabo de creer, que esto de hacerse fuentes debe de ser cosa importante para la salud. Apénas acabó Don Quixote de decir esta razon, quando con un gran golpe abriéron las puertas del aposento, y del sobresalto del golpe se le cayó á Doña Rodriguez la vela de la mano, y quedó la estancia como boca de lobo, como suele decirsc. Luego sintió la pobre dueña, que la asian de la garganta con dos manos tan fuertemente, que no la dexaban gañir, y que otra persona con mucha presteza, sin hablar palabra le alzaba las faldas, y con una, al parecer, chinela le comenzó á dar tantos azotes, que cra una compasion: y aunque Don Quixote se la tenia no se mencaba del lecho, y no sabia que podia ser aque$110, y$ estábase quedo y callando, $y$ aun temiendo no viniese por él la tanda y tunda azotesca: y no fué vano su temor, porque en dexando molida á la dueña los callados verdugos, la qual no osaba quejarse, acudiéron á Don Quixote, y desenvolviéndole de la sábana y de la colcha, le pellizcáron tan á menudo y tan reciamente, 
que no pudo dexar de defenderse á puñadas, y todo esto en silencio admirable. Duró la batalla casi media hora: soliéronse las fantasmas, recogió Doña Rodriguez sus faldas, y gimiendo su desgracia se salió por la puerta afucra sin decir palabra á Don Quixote, el qual doloroso y pellizcado, confuso y pensativo, se quedó solo, donde le dexarémos deseoso de saber quien habia sido $\mathrm{cl}$ perverso encantador que tal le habia puesto: pero ello se dirí á su tiempo, que Sancho Panza nos llama, y el buen concierto de la historia lo pide.

\section{CAPITULO XLIX.}

\section{De lo que le sucedió á, Sancho Panza rondando}

Dexámos al gran Gobernador enojado y mohino con el labrador pintor y socarron, el qual industriado del mayordomo, y el mayordomo del Duque, se burlaban de Sancho; pero él se las tenia tiesas á todos, magüera tonto, bronco y rollizo, y dixo á los que con él estaban, y al Doctor Pedro Recio, que como sc acabó el secreto de la carta del Duque habia vuelto á entrar en la sala: ahora verdaderamente que entiendo, que los Jueces y Gobernadores deben de ser, ó han de ser de bronce para no sentir las importunidades de los negociantes, que á todas horas y á todos tiempos quieren que los escuchen y despachen, atendiendo solo á su negocio, venga lo que vinicre, y si el pobre del Juez no los escucha y despacha, ó porque no pucde, ó porque no es aquel cl tiempo diputado para darles audiencia, luego le maldicen y murmuran, $y$ le roen los huesos, $y$ aun le des- lindan los linages. Negociante necio, negociante mentecato, no te apresures, espera sazon y coyuntura para negociar : no vengas á la hora del comer, ni á la del dormir, que los Jueces son de carne y de hueso, y han de dar á la naturaleza lo que naturalmente les pide , sino es yo que no le doy de comer á la mia, merced al señor Doctor Pedro Recio Tirteafuera, que está delante, que quicre que muera de hambre, y afirma que esta mucrte es vida, que así se la dé Dios á él, y á todos los de su ralea, digo á la de los malos médicos, que la de los buenos, palmas y lauros merecen. Todos los que conocian á Sancho Panza se admiraban, oyéndole hablar tan elegantemcnte, y no sabian á que atribuir10, sino á que los oficios y cargos graves, ó adoban, ó entorpecen los entendimientos. Finalmente el Doctor Pedro Recio Agüero de Tirteafuera prometió de darle de cenar aquella noche, aunque excediese de todos los aforismos de Hipócrates. Con esto quedó contento el Go bernador, y esperaba con grande ansia llegase la noche y la hora de cenar, $y$ aunque el ticmpo, al parecer suyo, se estaba quedo sin moverse de un lugar, todavía se llegó por él tanto deseado, donde le diéron de cenar un salpicon de vaca con cebolla, y unas manos cocidas de ternera algo entrada en dias. Entregóse en todo con mas gusto, que si le hubieran dado francolines de Milan, faysanes de Roma, ternera de Sorrento, perdices de Moron, ó gansos de Lavájos, y entre la cena volviéndose al Doctor, le dixo : mirad, señor Doctor, de aquí adelante no os cureis de darme á comcr cosas regaladas, ni manjares exquisitos porque será sacar á mi estómago de sus quicios, el qual estí acostumbrado á cabra, á vaTON. $1 \mathrm{v}$. 
ca á tocino á cecinz á nabos y á cebollas, y si acaso le dan otros manjares de Palacio, los recibe con melindre, $y$ algunas veces con asco: lo que el maestresala puedc hacer, es traerme estas que llaman ollas podridas, que miéntras mas podridas son, mejor huelen, $y$ en cllas puede embaular y encerrar todo lo que él quisiere, como sea de comer, que yo se lo agradeceré y se lo pagaré algun dia : y no se burle nadie conmigo, porque, ó somos, ó no somos: vivamos todos, y comamos en buena paz y compaña, pues quando Dios amanece, para todos amanece : yo gobernaré esta Insula sin perdonar derecho, ni llevar cohecho, $\mathrm{y}$ todo $\mathrm{cl}$ mundo traiga el ojo alerta, y mire por el virote, porque les hago saber, que el diablo está en Cantillana, y que si me dan ocasion, han de ver maravillas : no si no haceos miel, y coméros han moscas. Por cierto, señor Gobernador, dixo el maestresala, que vuesa merced tiene mucha razon en quanto ha dicho: y que yo ofrezco en nombre de todos los Insulanos desta Insula, que han de servir á vuesa merced con toda puntualidad, amor y benevolencia, porque el suave modo de gobernar que en estos principios vuesa merced ha dado, no les da lugar de hacer, ni de pensar cosa que en deservicio de vuesa merced redunde. Yo lo creo, respondió Sancho, y serian ellos unos necios, si otra cosa hiciesen, ó pensasen, y vuelvo á decir que se tenga cuenta con mi sustento, y con el de mi rucio, que es lo que en este negocio importa, y hace mas al caso, $y$ en siendo hora vamos á rondar, que es $\mathrm{mi}$ intencion limpiar esta Insula de todo género de inmundicia, y de gente vagamunda, holgazanes y malentretenida : porque quiero que sepais, amigos, que la gente valdía $y$ perezosa es en lo República 10 mesmo que los zánganos en las colmenas, que se comen la miel que las trabajadoras abcjas hacen. Pienso favorecer á los labradores, guardar sus preeminencias á los hidalgos, premiar los virtuosos, y sobre todo tener respeto á la Religion y á la honra de los Religiosos. ¿Que os parece de csto, amigos? ¿digo algo, ó quiébrome la cabeza? Dice tanto vucsa merced, señor Gobernador, dixo el mayordomo, que cstoy admirado de ver que un hombre tan sin letras como vuesa merced, que á lo que creo no tiene ninguna, diga tales y tantas cosas llenas de sentencias, $\mathrm{y}$ de avisos tan fucra de todo aquello que del ingenio de ruesa merced esperaban los que nos enviáron y los que aquí venimos : cada dia se ven cosas nuevas en el mundo : las burlas se vuclven en véras, y los burladorcs se hallan hurlados. Llegó la noche, y cenó cl Gobernador con licencia del señor Doctor Recio. Aderezáronse de ronda, salió con el mayordomo, secretario y maestresala, y cl coronista que tenia cuidado de poner en memoria sus hechos, $y$ alguaciles $y$ escribanos tantos, que podian formar un mediano esquadron. Iba Sancho cn medio con su vara, que no habia mas que ver, y pocas calles andadas del Lugar, sintiéron ruido de cuchilladas : acudiéron allá, y halláron que eran dos solos hombres los que reñian, los quales viendo venir á la Justicia , se estuviéron quedos, y el uno dellos dixo: aquí de Dios y del Rey, como iy que se ha de sufrir que roben en poblado en este pueblo, y que salgan á saltear cn la mitad de las calles? Sosegaos, hombre de bien, dixo Sancho, y contadme que es la causa desta pendencia, que yo soy el Gobernador. El otro contrario dixo: Tom. 
scinor Gobcrnador, yo la dire con toda brevedad: vuesit merced sabrá que este gentilhombre acaba de ganar ahora en esta casa de juego que está aquí frontero mas de mil reales, y sabe Dios como, y hallándome yo presente , juzgué mas de una sterte dudosa en su favor contra todo aquello que me dictaba la conciencia : alzósc con la ganancia y quando esperaba que me habia de dar algun escudo por lo ménos de barato, como es uso y costumbre darle á los hombres principales como yo, que cstamos asistentes para bien y mal pasar, y para apovar sinrazones y evitar pendencias, él embolsó su dincro, y se salió de la casa, yo vine despechado tras él, y con buenas y corteses palabras le he pedido, que me dicse siquicra ocho reales, pues sabe que yo soy hombre honrado, y que no tengo oficio, ni bencficio, porque mis padres no me le enscúáron, ni me le dexúron, y el socarron, que no es mas ladron que Caco, ni mas fullero que Andradilla, no queria darme mas de quatro reales, porque vea vuesa merced scñor Gobernator, que poca vergüenza y que poca conciencia; pero á fi que si vuesa merced no llegara, oue yo le hicicra vomitar la ganancia, $y$ que habia de saber con quantas entraba la romana. ¿Que decis vos á esto? preguntó Sancho. Y el otro respondió que era verdad quanto su contrario decia, y no habia qucrido darle mas de quatro reales, porque se los daba muchas veces, y los que esperan barato han de ser comedidos, y tomar con rostro alegre lo que les dieren, sin ponerse en cuentas con los gananciosos, si ya no supiesen de cierto que son fulleros, y que lo que ganan es mal ganado, y que para scinal que él era hombre de bien, y no ladron, como decia, ninguna habia mayor que cl no haberle querido dar nada, que siempre los fulleros son tributarios de los mirones que los conocen. Así es dixo el mayordomo, vea ruesa mereed señor Grobernator, que es lo que se ha de hacer destos hombres. Lo que se ha de hacer es esto, respondió Sancho: vos gunancioso, bueno, ó malo, ó indifurente, dad luego á este vuestro acuchillador cien reales, y mas habcis de desembolsar treinta para los pobres de la círcel, $y$ vos que no tencis oficio, ni bencificio, $y$ andais de nónes en estí Íasula, tomad lucgo esos cien reales, y maInana en todo 1 dia salid desta Insula desterrado por diez años, so pena, si lo quebrantúredes, los cumplais en la otra vida, colgándoos yo de una picota, ó aloménos el verdugo por mi mandado, y ninguno me replique, que le asentaré la mano. Desembolsó el uno, rccibió $\mathrm{cl}$ otro, este se salió de lia Insula, y aquel se fué á su casa, y el Gobcrnador quedó diciendo: ahora, yo podré poco, ó quitaré estas casas de juego, que á mi se me trasluee que son muy perjuliciales. Esta aloménos, dixo un escribano, no la podrí vuesa merced quitar, porque la ticne un gran personage, y mas es sin comparacion lo que él picrde al año, que lo que saca de los naypes: contra otros garitos de menor cantía podrá vuesa mereed mostrar su poder, que son los que mas daño hacen, y mas insolencias encubren, que en las casas de los caballeros principales $y$ de los Señores, no se atreven los famosos fulleros á usar de sus tretas: $y$ pues el vicio del juego se ha vuelro en excrcicio comun, mejor es que se juegue en casas principales, que no en la de algun oficial, donde cogen á un desdichado de media noche abaxo y le desueIlan vivo. Agora, escribano, dixo Sancho, yo sé que 
1.6

DON QUIXOTE DE LA MANCHA

hay mucho que decir en eso. $\mathrm{Y}$ en esto llegó un corchete, que traia asido á un mozo, y dixo : señor Gobernador, este mancebo venia hícia nosotros, y así como columbró la Justicia, volvió las espaldas y comenzó á correr como un gamo, señal que debe de ser algun delinqüente : yo parti tras él , y si no fuera porque tropezó, y cayó, no le alcanzara jamas. :Por que huias, hombre? preguntó Sancho. Á lo que el mozo respondió : señor, por excusar de responder á las muchas preguntas que las Justicias hacen. ¿Que oficio tienes? Texedor. : Y que texes? Hierros de lanzas con licencia buena de vuesa merced. ¿Graciosico me sois? ¿ de chocarrero os picais? Está bien. ¿Y adonde íbades ahora? Señor, á tomar cl ayre. ¿ $Y$ adonde se toma cl ayre en esta Insula? Adonde sopla. Bueno, respondeis muy á propósito, discreto sois, mancebo; pero haced cuenta que yo soy el ayre, y quc os soplo en popa, y os encamino á la cárcel. Asilde, ola y llevadle, que yo haré que ducrma allí sin ayre csta noche. Par Dios, dixo el mozo, así me haga vuesa merced dormir en la cárcel, como hacerme Rey. ¿ Pucs por que no te haré yo dormir en la cárcel? respondió Sancho ino tengo yo poder para prenderte, y soltarte cada $y$ quando que quisiere? Por mas poder que vuesa merced tenga, dixo el mozo, no será bastante para hacerme dormir en la cárcel. ¿Como que no? replicó Sancho: llevalde luego, donde verá por sus ojos cl desengaño, aunque mas el alcayde quiera usar con él de si interesa liberalidad, que yo le pondré pena de dos mil ducados si te dexa salir un paso de la cárcel. Todo eso es cosa de risa respondió el mozo: el caso es, que no me harán dormir en la cárcel quantos hoy viven. Dime, demonio, dixo
PARTE II. CAPIIUIO XIIX.

Sancho ¿tienes algun Ángel que te saque, y que te quite los grillos que te pienso mandar echar? Ahora, señor Gobernador, respondió el mozo con muy buen donayre, estemos á razon y vengamos al punto. Prosuponga vuesa merced que me manda llevar á la cárcel, y que en ella me echan grillos y cadenas, $y$ que me meten en un calabozo, y se le ponen al alcayde graves penas si me dexa salir, y que él lo cumple como se le manda: con todo esto, si yo no quiero dormir, y estarme despier to toda la noche sin pegar pestaña ¿será yuesa merced bastante con todo su poder para hacerme dormir, si yo no quiero? No por cierto, dixo el secretario, y el hombre ha salido con su intencion. De modo, dixo Sancho ¿que no dexaréis de dormir por otra cosa, que por vuestra voluntad, y no por contravenir á la mia? No señor, dixo el mozo, ni por pienso. Pues andad con Dios, dixo Sancho, ídos á dormir á vuestra casa , y Dios os dé buen sueño, que yo no quiero quitárosle; pero aconséjoos, que de aquí adelante no os burleis con 1a Justicia, porque toparéis con alguna que os dé con la burla en los cascos. Fuése el mozo, y el Gobernador prosiguió con su ronda, y de allí á poco viniéron dos corchetes, que traian á un hombre asido, y dixéron: senor Gobernador, este que parece hombre, no lo es, sino muger, y no fea, que viene vestida en hábito de hom:bre. Llegáronle á los ojos dos, ó tres lanternas, á cuyas luces descubriéron un rostro de una muger, al parecer de diez y seis, ó pocos mas años, recogidos los cabellos con una redecilla de oro y secia verde, hermosa como mil perlas: miráronla de arriba abaxo, y viéron que venia con unas medias de seda encarnada, con ligas 
I 28

DON CUIXOTE DE IA MANCHA

de tafetan blanco, y rapacejos de oro y aljófar, los gregüescos eran verdes de tcla de oro, y una saltaembarca, ó ropilla de lo mesmo suelta, debaxo de la qual traia un jubon de tela finísima de oro, y blanco y los zapatos eran blancos, y de hombre: no traia espada ceñida, sino una riquísima daga, y en los dedos muchos y muy buenos anillos. Finalmente la moza parecia bien á todos, $y$ ninguno la conoció de quantos la viéron, $y$ los naturales del Lugar dixéron que no podian pensar quien fuese, $y$ los consabidores de las burlas que se habian de hacer á Sancho, fuéron los que mas se admiráron, porque aquel suceso y hallazgo no venia ordenado por cllos, y así estaban dudosos esperando en que pararia el caso. Sancho quedó pasmado de la hermosura de la moza, y preguntóle quien era, adonde iba, y que ocasion le habia movido para vestirse en aquel hábito? Ella puestos los ojos en tierra, con honestísima vergüenza, respondió : no puedo, señor, decir tan en público lo que tanto the importaba fuera secreto : una cosa quiero que se cntienda, que no soy ladron, ni persona facinorosa, sino une doncella desdichada á quien la fuerza de unos zelos ha hecho romper el decoro que á la honesticad se debe. Oyendo csto el mayordomo, dixo á Sancho: haga, señor Gobernador, apartar la gente, porque esta señora con ménos empacho pucda decir lo que quisiere. Mandólo así cl Gobernador, apartáronse todos, sino fuéron el mayordomo, maestresalia y el secretario. Viéndose pues solos, la doncella prosiguió diciendo : yo, seño res, soy hija de l'edro Perez Mazorca, arrendador de casa de mi padrc. Eso no lleva camino, dixo el mayordo-
PARTE II. CAPITULOXITX.

mo, señora, porque yo conozco muy bien á Pedro Pcrez, y sé que no tiene hijo ninguno, ni varon, ni hembra: y mas, que decis, que es vuestro padre, y luego añadis, que suele ir muchas veces en casa de vuestro padre. Ya yo habia dado en ello, dixo Sancho. Ahora, señores, yo estoy turbada, y no sé lo que me digo, respondió la doncella; pero la verdad es, que yo soy hija de Diego de la Llana, que todos vuesas mercedes deben de conocer. Aun eso lleva camino, respondió el mayordomo, que yo conozco á Diego de la Llana, y sé que es un hidalgo principal $y$ rico, $y$ que tiene un hijo $y$ una hija, y que despues que enviudó no ha habido nadie en todo este Lugar, que pueda decir que ha visto el rostro de su hija, que la tiene tan cncerrada, que no da lugar al sol que la vea, $y$ con todo esto la fama dice que es en extremo hermosa. Así es la verdad, respondió la doncella, y esa hija soy yo: si la fama miente, ó no en mi hermosura, ya os habréis, señores, desenganado, pucs me habeis visto, y en csto comenzó á llorar tiernamente. Viendo lo qual el secretario, se llegó al oido del maestresaia, y le dixo muy paso: sin duda alguna que á esta pobre doncella le debe de haber sucedido algo de importancia, pues en tal trage, y á tales horas, $y$ siendo tan principal, anda fucra de su casa. No hay dudar en eso, respondió el maestresala, y mas que csa sospecha la confirman sus lágrimas. Sancho la consoló con las mcjores razones que él supo, y le pidió que sin temor alguno les dixese lo que le habia sucedido, que todos procurarian remediarlo con muchas véras y por todas las vias posibles. Es el caso, señores, respondió ella, que mi padre me ha tenido encerrada diez años ron. iv. 
I 30

DON QUTXOTE DE LA MANCHA

ha, que son los mismos que á mi madre come la tierra: en casa dicen misa en un rico Oratorio, $y$ yo en todo este tiempo no he visto que el sol del cielo de dita, y la luna y las estrellas de noche, ni sé que son calles, plazas, ni templos, ni aun hombres, fuera de mi padre, $y$ de un hermano mio, y de Pedro Perez el arrendador, que por entrar de ordinario en mi casa, se me antojo decir que era mi padre, por no declarar el mio. Este encerramiento y este negarme cl salir de casa, siquicra i la Iglesia, ha muchos dias y meses que me trac muy desconsolada : quisiera yo ver el mundo, ó aloménos el pucblo donde nací, pareciéndome que este desco no iba contra el buen decoro que las doncellas principales deben guardar á sí mesmas. Quando oia decir, que corrian toros y jugaban cañas y se representaban comedias, preguntaba á mi hermano, que es un año menor que yo, que me dixese que cosas eran aquellas, $y$ otras muchas que yo no he visto : él me lo declaraba por los mejores modos que sabia; pero todo era encenderme mas el desco de verlo. Finalmente, por abreviar cl cuento de mi perdicion, digo que yo rogué y pedí á mi hermano, que nunca tal pidiera, ni tal rogara: y tornó í renovar el llanto. El mayordomo le dixo: prosiga ruesa merced, scñora, y acabe de decirnos lo que le ha sucedido, que nos tienen á todos suspensos sus palabras y sus lágrimas. Pocas me quedan por decir, respondió la doncella, aunque muchas lágrimas sí que llorar, porque los mal colocados deseos, no pueden traer consigo otros descuentos que los scmejantes. Habíase sentado en cl alma del maestresala la belleza de la doncella, y llegó otra vez su lanterna para verla de nuevo, y parecióle que no cran lá-
PARTEIT. CAPITULO XIIX.

grimas las que lloraba, sino aljófar, ó rocio de los prados, $y$ aun las subia de punto, y las llegaba á perlas orientales, y estaba deseando que su desgracia no fuese tanta como daban á entender los indicios de su llanto y de sus suspiros. Desesperábase el Gobernador de la tardanza que tenia la moza en dilatar su historia, y díxole que acabase de tenerlos mas suspensos, que era tarde, $y$ falraba mucho que andar del pueblo. Ella entre interrotos sollozos, y mal formados suspiros, dixo : no es otra mi desgracia, ni mi infortunio es otro, sino que yo rogué á mi hermano, que me vistiese en hábitos de hombre con uno de sus restidos, y que me sacase una noche á ver todo el pueblo, quando nuestro padre durmiese : él importunado de mis ruegos, condescendió con mi deseo, y poniéndome este vestido, y él vistiéndose de otro mio, que le está como nacido, porque él no ticne pelo de barba, $y$ no parece sino una doncella hermosísima: esta noche, debe de haber una hora, poco mas, ó ménos, nos salímos de casa, y guiados de nuestro mozo y desbaratado discurso hemos rodeado todo el pucblo, y quando queríamos volver á casa vímos venir un gran tropel de gente, y mi hermano me dixo: hermana, esta debe de ser la ronda, aligera los pies y pon alas en ellos, y vente tras mí corriendo, porque no nos conozcan, que nos será mal contado, y diciendo esto volvió las espaldas, y comenzó, no digo á correr, sino á volar: yo á ménos de seis pasos caí con cl sobresalto, y entónces llegó el ministro de la justicia, que me truxo ante vuesas mercedes, adonde por mala y antojadiza me veo avergonzada ante tanta gente. En efecto, seFrora, dixo Sancho ¿ no os ha sucedido otro desman alTom. $\mathrm{N}$. 
$P A B T E$ IT CAPSTULO $X L Y X$

guno, ni zelos, como yos al principio de vuestro cuento dixístes, no os sacáron de vuestra casa? No me ha sucedido nada, ni me sacáron zelos, sino solo el deseo de ver mundo, que no se extendia á mas que á ver las calles deste Lugar : y acabó de confirmar ser verdad lo que la doncella decia, llegar los corchetes con su hermano preso, á quien alcanzó uno dellos, quando se huyó de su hermana. No traia sino un faldellin rico y una mantellina de damasco azul con pasamanos de oro fino, la cabeza sin toca, ni con orra cosa adornada, que con sus mesmos cabellos, que eran sortijas de oro, segun eran rubios y cnrizados. Aparráronse con él el Gobernador, mayordomo y maestresala , y sin que lo oyese su hermana, le preguntáron, como venia en aquel trage, y él con no ménos vergüenza y empacho contó lo mesmo que su hermana habia contado, de que recibió gran gusto el cnamorado maestresala: pero el Gobernador les dixo: por cierto, señores, que esta ha sido una gran rapacería, y para contar esta necedad y atrevimiento no eran menester tantas largas, ni tantas lígrimas y suspiros, que con decir, somos fulano y fulana, que nos salímos á espaciar de casa de nuestros padres con esta invencion, solo por curiosidad, sin otro designio alguno, se acabara el cuento, y no gemidicos y lloramicos y darle. Así es la verdad, respondió la doncella ; pero sepan vuesas mercedes, que la turbacion que he tenido ha sido tanta, que no me ha dexado guardar el término que debia. No se ha perdido nada, respondió Sancho: vámos, y dexarémos á vuesas mercedes en casa de su padre, quizá no los habrá echado ménos, y de aquí adelante no se muestren tan niños, ni tan deseosos de ver mundo : que la doncella honrada, la pierna quebrada y en casa : y la muger y la gallina por andar se pierden aina : y la que es deseosa de ver, tambien tiene deseo de ser vista : no digo mas. El mancebo agradeció al Gobernador la merced que queria hacerles de volverlos á su casa , y así se encamináron hácia clla, que no estaba muy léjos de allí. Llegáron pues, y tirando el hermano una china á una reja, al momento baxó una criada, que los cstaba esperando, y les abrió la puerta, y ellos se entráron, dexando á todos admirados, así de su gentileza y hermosura, como del deseo que tenian de ver mundo de noche, $y$ sin salir del Lugar: pero todo lo atribuyéron á su poca edad. Quedó el macstresala traspasado su corazon, y propuso de luego otro dia pedírsela por muger á su padre, teniendo por cierto, que no se la negaria, por ser él criado del Duque : y aun á Sancho le viniéron deseos y barruntos de casar al mozo con Sanchica su hija y determinó de ponerlo en plática á su ticmpo, dándose á entender , que á una hija de un Gobernador ningun marido se le podia negar. Con esto se acabó la ronda de aquella noche, y de allí á dos dias el Gobierno, con que se destroncáron y borráron todos sus designios, como se verá adelante.

\section{CAPÍTULO L.}

Donde se declara quien fuéron los cncantadores y verdugos que azotíron á la dueña, y pellizcáron y arañáron á Don Quixote, con el suceso que tuvo el pa-

ge que llevó la carta á Teresa Sancha ${ }^{21}$, muger de Sancho Panza.

Dice Cide Hamete, puntualísimo escudrinador de los 
134

DON QUTXOTE DE LA MANCHA

átomos desta verdadera historia, que al tiempo que Doña Rodriguez salio de su aposento para ir á la estancia de Don Quixote, otra dueña que con clla dormia lo sintió , y que como todas las ducínas son amigas de saber, entender y oler, se fué tras ella con tanto silcncio, que la buena Rodriguez no lo echó de ver, y así como la dueña la vió entrar en la estancia de Don Quixote, porque no faltase en ella la general costumbre que todas las dueñas tienen de ser chismosas, al momento lo fué á poner en pico á su señora la Duquesa, de como Doña Rodriguez quedaba en el aposento de Don Quixote. La Duquesa se lo dixo al Duque, y le pidió licencia para que ella y Altisidora viniesen á ver lo que aquella ducña queria con Don Quixote. El Duque se la dió, y las dos con gran tiento y sosiego paso ante paso llegúron á ponerse junto á la puerta del aposento, y tan cerca que oian todo lo que dentro hablaban, y quando oyó la Duquesa que Rodriguez habia echado en la calle el Aran jucz de sus fuentes, no lo pudo sufrir, ni ménos Altisidora, y así llenas de cólcra y descosas de renganza, entráron de golpe en el apcsento y acrevilláron á Don Quixote, y vapuláron á la dueña del modo que queda contado, porque las afrentas que van derechas contra la hermosura y presuncion de las mugeres, despiertan en ellas en aran manera la ira, y encienden el deseo de vengarse. Contó la Duquesa al Duque lo que le habia pasado, de lo que se holgó mucho, y la Duquesa prosiguiendo con su intencion de burlarse y recibir pasatiempo con Don Quixote, despachó al page que habia hecho la figura de Dulcinca en el concierto de su desencanto, que tenia bien olvidado Sancho Panza con la ocupacion
PARTEII. CAPITUIO L.

de su Gobierno, á Teresa Panza su muger con la carta de su marido, y con otra suya, y con una gran sarta de corales ricos presentados. Dice pues la historia, que el page cra muy discreto y agudo, y con deseo de servir á sus señores, partió de muy buena gana al Lugar de Sancho, $y$ ántes de entrar en él vió en un arroyo estar lavando cantidad de mugeres, á quien preguntó, si le sabrian decir, si en aquel Lugar vivia una muger llamada Teresa Panza, muger de un cierto Sancho Panza, escudero de un Caballero Ilamado Don Quixote de la Mancha : á cuya pregunta se levantó en pie una mozucla, que estaba lavando, y dixo: esa Teresa Panza cs mi madre, y ese tal Sancho mi señor padre, y el tal caballero nuestro amo. Pues venid, doncella, dixo el page, y mostradme s vuestro madre, porque le traigo una carta, y un presente del tal vuestro padre. Eso hare yo de muy buena gana, scinor mio, respondió la moza, que mostraba ser de cdad de catorce años, poco mas á ménos, $y$ dexando la ropa que lavaba á otra companera, sin tocarsc ni calzarse, que estaba en picrnas y desgreñada, saltó delante de la cabalgadura del page, y dixo: venga vuesa merced, que á la cntrada del pucblo está nuestra casa, y mi madre en ella con harta pena por no haber sabido muchos dias ha de mi scñor padre. Pues yo se las llevo tan buenas, dixo el page, que ticne que dar bicn gracias á Dios por ellas. Finalmente saltando, corriendo y brincando llegó al pueblo la muchacha, y ántes de entrar en su cosa dixo á voces desde la puerta: salga, madre Teresa, salga, salga, que viene aquí un señor, que trae cartas, $y$ otras cosas de mi buen padre, cuyas voces salió Teresa Panza su madre, hilando un co- 
I 36

DON QUIXOTE DE XA MANCHA

po de estopa, con una saya parda. Parecia segun era de corta, que se la habian cortado por vergonzoso lugar: con un corpezuelo asimismo pardo, y una camisa de pechos. No era muy vieja, aunque mostraba pasar de los quarenta ; pero fuerte, tiesa, nervuda y avellanada, la qual viendo á su hija, y al page á caballo, le dixo ¿que cs esto, niña, que señor es este? Es un servidor de mi señora Doña Teresa Panza, respondió el page, y diciendo y haciendo se arrojó del caballo, y se fué con mucha humildad á poner de hinojos ante la scñora Teresa, diciendo: deme vuesa merced sus manos, mi señora Doña Teresa, bien así como muger legítima y particular dcI señor Don Sancho Panza, Gobernador propio de la Insu1a Barataria. iAy señor mio! quítese de ahí, no haga eso, respondió Teresa, que yo no soy nada palacicga, sino una pobre labradora, hija de un estripa terrones, y muger de un escudero andante, y no de Gobernador alguno. Vuesa merced, respondió el page, es muger dignísima de un Gobernador archîdignísimo , y para prucba desta verdad reciba vuesa merced esta carta y este presente: y sacó al instante de la faltriquera una sarta de corales con extremos de oro, y se la cchó al cucllo, y dixo: esta carta es del señor Gobernador, y otra que traigo y estos corales son de mi señora la Duquesa, que á vuesa merced me envia. Quedó pasmada Teresa, y su hija ni mas ni ménos, y la muchacha dixo : que me maten sino anda por aquí nuestro señor amo Don Quixote, que debe de haber dado á padre el Gobierno, ó Condado, que tantas veces le habia prometido. Así es la verdad, respondió el page, que por respeto del señor Don Quixote es ahora el señor Sancho Gobernador de la

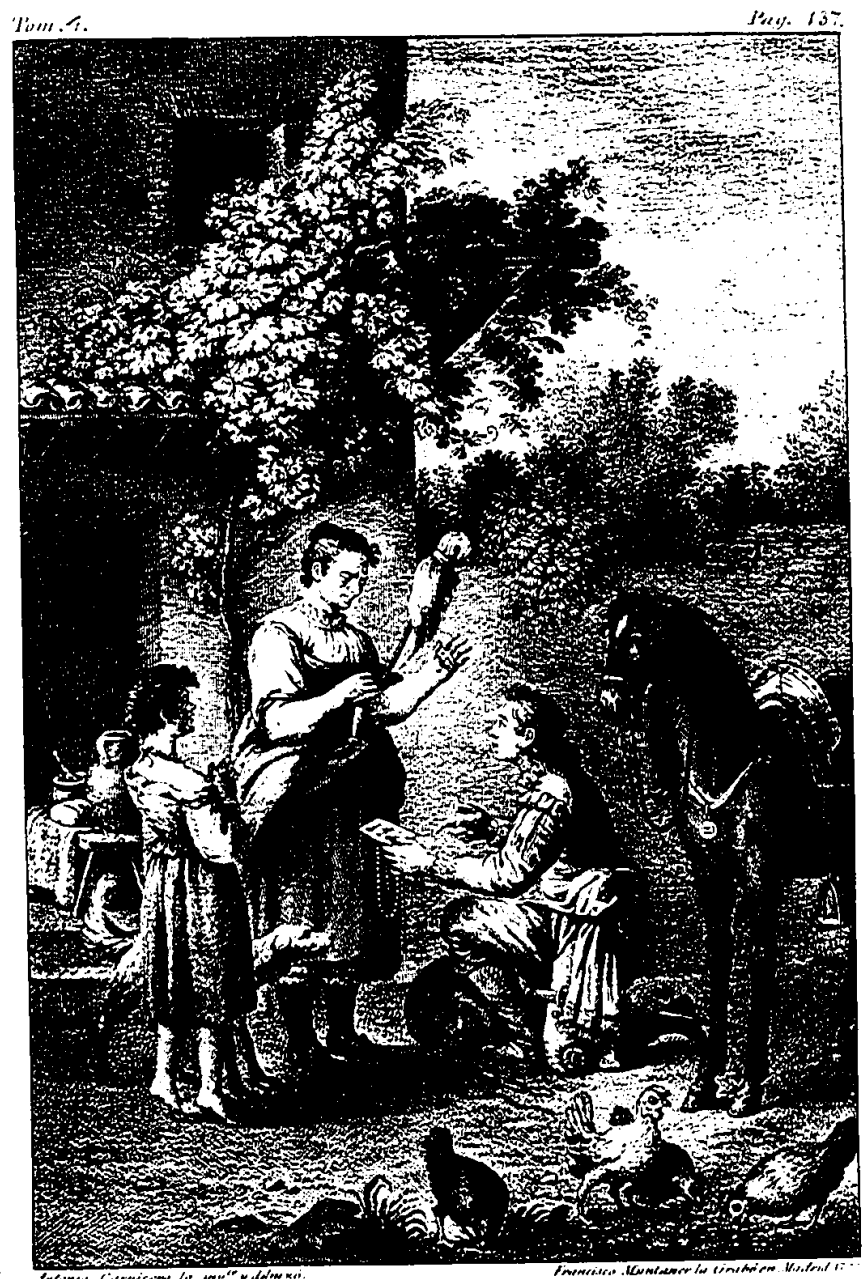


Insula Barataria, como se verá por esta carta. Léamela vuesa merced, señor gentilhombre, dixo Teresa, porque aunque yo sé hilar, no sé leer migaja. Ni yo tampoco, añadió Sanchica ; pero espérenme aquí, que yo iré llamar quien la lea, ora sea el Cura mesmo, ó el Ba chiller Sanson Carrasco, que vendrán de muy buena gana por saber nuevas de mi padre. No hay para que se llame á nadie, que yo no sé hilar ; pero sé leer, y la leeré, y así se la leyó toda, que por quedar ya referida no se pone aquí: y luego sacó otra de la Duquesa, que decia desta manera:

Amiga Teresa: las buenas partes de la bondad $y$ del ingenio de vuestro marido Sancho, me moviéron $y$ obligáron á pedir á mi marido el Duque lo diese un Gobierno de una Ínsula, de muchas que tiene. Tengo noticia que gobicrna como un girifalte, de lo que yo estoy muy contenta, y el Dugue mi señor por el consiguiente, por lo que doy muchas gracias al Cielo do no haberme engañado en haberle escogido para el tal Gobierno, porque quicro que sepa la señora Teresa que con dificultad se halla un buen Gobernador en el mundo, y tal me haga a mi Dios, como Sancho robierna. Alii le envio, querida mia, una sarta de corales con extremos de oro: yo me holgara, que fuera de perlas orientales; pero quicn te da el hueso, no te querria ver muerta, tiempo vendrá en que nos conozcamos, y nos comuniquemos, y Dios sabe lo que será. Encomiéndeme á Sanchica su hija, y digale de mi parte, que se apareje, que la tengo de casar altamente, quando minos lo piense. Dicenme que en ese Lugar hay bellotas gordas, envicme hasta dos docenas, que las estimare Tom. sv. 
an macho por ser de su mano, y escribame largo, avisándome de su salud y de su bien estar, y si hubie$r$ monester alguna cosa, no tiene que hacer mas que boguear, que su boca será medida: y Dios me la guarde. Deste Lugar, su amiga que bien la quicre,

\section{La Duquesa.}

Ay! dixo Teresa en oycndo la carta, y que buena y que llana y que humilde señora: con estas tales señoras me entierren á mí, y no las hidalgas que en este pueblo se usan, que piensan que por ser hidalgas no las ha de tocar el viento, y van á la Iglesia con tanta fantasía, como si fuesen las mesmas Reynas, que no parece sino que tienen á deshonra el mirar á una labradora, y veis aquí donde esta buena señora, con ser Duquesa, me llama amiga, y me trata como si fuera su igual, que igual la vea yo con el mas alto campanario que hay en la Mancha: y en lo que toca á las bellotas, scñor mio, yo le cnviaré á su Señoría un celemin que por gordas las pueden venir á ver á la mira y á la maravilla : y por ahora, Sanchica, atiende á que se regale este señor, pon en órden este caballo, y saca de la caballeriza huevos, y corta tocino adunia, y démosle de comer como á un Príncipe, que las buenas nuevas que nos ha traido, y la buena cara que él tiene lo merece todo, y en tanto saldré yo á dar á mis vecinas la nuevas de nuestro contento, y al Padre Cura y á Maese Nicolas el Barbero, que tan amigos son y han sido de tu padre. Sí haré, madre, respondió Sanchica pero mire que me ha de dar la mitad desa sarta, que no tengo yo por tan boba á mi señora la Duquesa, que se la habia de enviar á ella toda. Todo es para ti, hija, respondió Teresa; pero déxamela traer algunos dias al cuello, que verdaderamente parece que me alegra el corazon. Tambien se alegrarán, dixo el page, quando vean el lio que vicne en este portamanteo, que es un vestido de paño finísimo, que el Gobernador solo un dia llevó á caza, el qual todo le envia para la señora Sanchica. Que me viva él mil años, respondió Sanchica, y el que lo trae ni mas ni ménos, $y$ aun dos mil si fucre necesidad. Salióse en esto Teresa fuera de casa con las cartas y con la sarta al cuello, y iba tańendo en las cartas, como si fuera en un pandero, y encontrándose acaso con cl Cura y Sanson Carrasco, comenzó á baylar $y$ á decir: á fe, que agora que no hay pariente pobre, Gobiernito tenemos, no sino tómese conmigo la mas pintada hidalga, que yo la pondré como nueva. ¿Que es esto, Teresa Panza? ¿que locuras son estas, y que papeles son esos? No es otra la locura, sino que cstas son cartas de Duquesas y de Gobernadores, y estos que traigo al cuello son corales finos las Ave Marías, y los Padres nuestros son de oro de martillo, y yo soy Gobernadora. De Dios en ayuso no os entendemos, Teresa, ni sabemos lo que os decis. Ahí lo podrán ver ellos, respondió Teresa, y dióles las cartas. Leyólas el Cura de modo, que las oyó Sanson Carrasco : y Sanson y el Cura se miráron el uno al otro, como admirados de lo que habian leido : y preguntó el Bachiller, quien habia traido aquellas cartas. Respondió Teresa, que se vinicsen con ellaá su casa, y verian al mensagero, que era un mancebo como un pino de oro, $y$ que le trais otro presente, que valia mas de ranto. Quitóle el Cura los corales del cuello, y ron. $\mathrm{N}$. 
mirólos y remirólos, y certificándose que eran finos, tornó á admirarse de nuevo, y dixo: por cl hábito que tengo, que no sé que me diga, ni que me piense destas cartas y destos prescnes: por una parte veo y toco la fineza destos corales, y por otra lco, que una Duquesa envia á pedir dos docenas de bellotas. Aderézame esas medidas, dixo entónces Carrasco: agora bien, vamos á ver al portador deste pliço, que dél nos informarémos de las dificuldeste plue nos ofrecen. Hiciéronlo así, y volvióse Teresa con ellos. Halláron al paye cribando un poco de cebada para su cabalgadura, y á Sanchica cortando un torrezno para empedrarle con huevos, y dar de comer al page, cuya presencia y buen adorno contentó mucho á los dos, y despues de haberle saludado cortesmente, y él á ellos, le preguntó Sanson les dixese nuevas, así de Don Quixote como de Sancho Panza, que puesto que habian leido las cartas de Sancho y de la señora Duquesa, todavía estaban confusos, y no acababan de atinar que seria aquello del Gobierno de Sancho, y mas de una Insula siendo todas, ó las mas que hay en el mar medicerraneo de su Magestad. A lo que el page respondió : de que el señor Sancho Panza sea Gobernador, no hay que dudar en ello, de que sea Insula, ó no la que gobierna, en eso no me entremeto; pero basta que sea un Lugar de mas de mil vecinos : y en quanto á lo de las bellotas, digo que mi señora la Duquesa es tan llana y tan humilde, que no decia el enviar á pedir bellotas á una labradora; pero que le acontecia enviar á pedir un peyne prestado á una vecin suya: porque quiero que scpan vucsas mercedcs, que las Scinoras de Aragon aunque son tan principales, no son tan puntuosas y levan- tadas como las Scñoras Castellanas : con mas llancza tratan con las gentes. Estando en la mitad destas pláticas, saltó Sanchica con un halda de huevos, y preguntó al page : dírame señor : mi señor padre trae por ventura calzas aracadas despues que es Gobernador: No he mirado en ello, respondió el page; pero sí debe de traer. ¡Ay Dios mio! replicó Sanchica, y que será de ver á mi padre con pedorreras: : no es bueno, sino que desde que naci tengo deseo de ver a mi padre con calzas atacadas: Como con esas cosas le verá vuesa merced si vive, respondió el page. Par Dios, términos lleva de caminar con papahigo, con solos dos meses que le dure el Gobierno. Bien echáron de ver el Cura y el Bachiller, que el page hablaba socarronamente; pero la fineza de los corales y el vestido de caza que Sancho enviaba, lo deshacia todo (que ya Teresa les habia mostrado cl vestido) y no dexáron de reirse del deseo de Sanchica, y mas quando Teresa dixo: señor Curs, eche cara por ahí si hay alguien que vaya á Madrid, ó á Toledo, para que me compre un verdugado redondo, hecho y derecho, y sea al uso, $\mathrm{y}$ de los mejores que hubiere, que en verdad, en verdad, que tengo de honrar el Gobierno de mi marido en quanto yo pudiere, $y$ aun, que, si me enojo, me tengo de ir á esa Corte, y echar un coche como todas, que la que tiene marido Gobernador, muy bien le puede traer y sustentar. Y como, madre, dixo Sanchica, pluguiese á Dios que fuese intes hoy que mañana, aunque dixesen los que me viesen ir sentada con mi señora madre en aquel coche: mirad la tal por qual, hija del harto de ajos, y como va sentada y tendida en cl coche, como si fuera una Papcsa. Pero pisen ellos los lodos, y án- 
deme yo en mi coche levantados los pics del suelo. Mal año y mal mes para quantos murmuradores. hay en el mundo : $y$ ándeme yo caliente, $y$ ríase la gente. -Digo bicn, madre mia? Y como que dices bien, hija, respondió Teresa, y todas estas venturas $y$ aun mayores me las tiene proferizadas mi buen Sancho, y verás tú, hija, como no para hasta hacerme Condesa, que todo es comenzar a chas veces á tu buen padre (que así como lo es tuyo, lo es de los refranes) quando te dieren la vaquilla, corre con la soguilla : quando te dieren un Gobierno, cógele, quando te dicren un Condado, agárrale, y quando te hicieren tus tus con alguna buena dádiva, embásala : no sino dormios, y no respondais á las venturas, $y$ buenas dichas que están llamando á la puerta de vuestra casa. ¿ Y que se me da á mí, añadió Sanchica, que diga el que quisiere, quando me vea entonada y fantasiosa: vióse el perro en bragas de cerro, y lo demas? Oyendo lo qual el Cura, dixo: yo no puedo creer sino que todos los deste linage de los Panzas, naciéron cada uno con un costal de refranes en cl cucrpo: ninguno dellos he visto que no los derrame á todas horas, y en todas las pláticas que tienen. Así es la verdad, dixo el page, que el señor Go bernador Sancho, á cada paso los dice, y aunque muchos no vienen á propósito, todavía dan gusto, y mi senora la Duquesa y el Duque los celebran mucho. ¿Que todavía se afirma vuesa merced, señor mio, dixo el $\mathrm{Ba}$ chiller, ser verdad esto del Gobierno de Sancho, y de que hay Duquesa en cl mundo, que le envie presentes y le escriba? porque nosotros, aunque tocamos los presentes, $y$ hemos lcido las cartas, no lo creemos, y pensamos que esta es una de las cosas de Don Quixote puestro compatrioto, que todas piensa que son hechas por encantamento : $y$ así estoy por decir, que quiero tocar y palpar á vuesa merced por ver si es Embaxador fantástico, ó hombre de carne y hueso. Señores, yo no sé mas de mí, respondió el page, sino que soy Embaxador verdadero, y que el señor Sancho Panza es Gobernador efectivo, y que mis señores Duque y Duquesa pueden dar, y han dado el tal Gobierno, y que he oido decir, que en él se porta valentísimamente el tal Sancho Panza: si en esto hay encantamento, ó no, vuesas mercedes lo disputen allá entre ellos, que yo no sé otra cosa para el juramento que hago, que es, por vida de mis padres, que los tengo vivos, $y$ los amo y los quiero mucho. Bien podrá ello ser así, replicó el Bachiller ; pero dubitat Audrá ello ser así , replicó el Bachiller ; pero dubitat Aut
gustinus. Dude quien dudare, respondió el page, la verdad es la que he dicho, y esta que ha de andar siempre sobre la mentira, como el aceyte sobre el agua, y si no opribus crédite ot non verbis : véngase alguno de vuesas mercedes conmigo, y verán con los ojos lo que no creen por los oidos. Esa ida á mí toca, dixo Sanchica, lléveme vuesa mcrced, señor, á las ancas de su rocin, que yo iré de muy buena gana á ver á mi señor padre. Las hijas de los Gobernadores ${ }^{23}$ no han de ir solas por los caminos, sino acompañadas de carrozas y literas, y de gran número de sirvientes. Par Dios, respondió Sanchio tambien me vaya yo sobre una pollina, codo Sancher, tambien me vaya yo sobre unapolina colla mochacha, dixo Teresa, que no sabes lo que te dices, y este señor está en lo cierto, que tal el tiempo, tal el tiento : quando Sancho, Sancha, y quando Go- 
144

DON QUIXOTE DE IA MANCHA

bernador, Señora, y no sé si digo algo. Mas dice la señora Teresa de lo que piensa, dixo el page, y denme de comer, y despáchenme luego, porque pienso volverme esta tarde. A lo que dixo el Cura : vuesa merced se vendrá á hacer penitencia conmigo, que la señora $\mathrm{Te}$ resa mas tiene voluntad, que alhajas para servir á tan buen huésped. Rehusólo el page; pero en efecto lo hubo de conceder por su mcjora, y el Cura le llevó consigo de buena gana, por tener lugar de preguntarle de espacio por Don Quixote y sus hazanias. El Bachiller se ofreció de escribir las cartas á Teresa de la respuesta; pero ella no quiso que el Bachiller se metiese en sus cosas, que le tenia por algo burlon, y así dió un bollo, y dos huevos á un monacillo que sabia escribir, el qual le escribió dos cartas, una para su marido, y otra para la Duquesa, notadas de su mismo caletre, que no son las peores que en esta grande historia se ponen, como se verá adelante.

\section{CAPÍTULO LI.}

Del progreso del Gobierno de Sancho Panza, con otros sucesos tales como buenos.

Amaneció el dia , que se siguió á la noche de la ronda del Gobernador, la qual el maestresala pasó sin dormir, ocupado el pensamiento en el rostro, brio y belleza de la disfrazada doncella, y el mayordomo ocupó lo que della faltaba en escribir á sus señores lo que Sancho Panza hacia y decia, tan admirado de sus hechos como de sus dichos, porque andaban mezcladas sus palabras y sus acciones con asomos discretos y tontos. Levantóse en fin el señor Gobernador, y por órden del Doctor
PARTEII. CAPÍTUIO II.

Pedro Recio le hiciéron desayunar con un poco de conserva y quatro tragos de agua fria, cosa que la trocara Sancho con un pedazo de pan y un racimo de uvas; pero viendo que aquello era mas fuerza que voluntad, pasó por cllo con harto dolor de su alma y fatiga de su estómngo, haciéndole creer Pedro Recio, que los manjares pocos y delicados avivaban el ingenio, que era lo que mas convenia á las personas constituidas en mandos y en oficios graves, donde se han de aprovechar, no tanto de las fuerzas corporales, como de las del entendimiento. Con esta sofistería padecia hambre Sancho, y tal, que en su secreto maldecia el Gobierno, y aun á quien se le habia dado; pero con su hambre y con su conserva, se puso á juzgar aquel dia, y lo primero que se le ofreció, fué una pregunta que un forastero le hizo, estando presentes á todo el mayordomo y los demas acólitos, que fué : señor, un caudaloso rio dividia dos términos de un mismo señorío (y esté vuesa merced atento, porque el caso cs de importancia, $y$ algo dificultoso) digo pues, que sobre este rio estaba una puentc, y al cabo della una horca, y una como casa de audiencia, en la qual de ordinario habia quatro jueces que juzgaban la ley que puso el dueño del rio, de la puente y del señorío que era en esta forma: si alguno pasare por esta puente de una parte á otra, ha de jurar primero adonde y á que va, y si jurare verdad, déxcnle pasar, y si dixere mentira, muera por ello ahorcado en la horca que allí se muestra, sin remision alguna. Sabida esta ley, y la rigurosa condicion della, pasaban muchos, y luego en lo que juraban se echaba de ver que decian verdad, y los jueccs los dexaban pasar iibremente. Suton. Iv. 
cedió pues, que tomando juramento á un hombre, juró, y dixo que para el juramento que hacia, que iba á morir en aquella horca que allí estaba, y no á otra cosa. Reparáron los jueces en el juramento, y dixéron : si á este hombre le dexamos pasar libremente, mintió en su juramento, y conforme á la ley debe morir, y si le ahorcamos, él juró que iba á morir en aquella horca, y habiendo jurado verdad, por la misma ley debe ser libre. Pídese á vuesa merced, señor Gobernador ¿que harán los jueces del tal hombre, que aun hasta agora están dudosos y suspensos? y habiendo tenido noticia del agudo y elevado entendimiento de vuesa merced, me enviáron á mí á que suplicase á vuesa merced de su parte dicse su parecer en tan intricado y dudoso caso. $A$ lo que respondió Sancho: por cierto que esos señores jueces que á mí os envian, lo pudieran haber excusado, porque yo soy un hombre que tengo mas de mostrenco que de agudo; pero con todo eso, repetidme otra vez el negocio de modo que yo le entienda, quizá podria ser que diese en el hito. Volvió otra y otra vez el preguntante á referir lo que primero habia dicho, y Sancho dixo : á mi parecer este negocio cn dos paletas le declararé yo, y es así ; cl tal hombre jura que va á morir en la horca, y si muere en ella juró verdad, $y$ por la ley puesta merece ser libre, y que pase la puente, y si no le ahorcan juró mentira, y por la misma ley merece que le ahorquen? Así es, como el señor Gobernador dice, dixo el mensagero, y quanto á la entereza y entendimiento del caso, no hay mas que pedir, ni que dudar. Digo yo pues agora, replicó Sancho, que deste hombre aquella parte que juró verdad la dexen pasar, y la que dixo mentira
PARTEIT. CAPÍtULOLI.

la ahorquen, y desta manera se cumplirá al pic de la lctra la condicion del pasage. Pues, señor Gobernador, replicó el preguntador, serí necesario que el tal hombre se divida en partes, en mentirosa y verdadera, y si se divide, por fuerza ha de morir : y así no se consigue cosa alguna de lo que la ley pide, y es de necesidad expresa que se cumpla con ella. Venid acá, señor buen hombre, respondió Sancho, este pasagero que decis, o yo soy un porro, ó él tiene la misma razon para morir que para vivir y pasar la puente, porque si la verdad le salva, la mentira le condena igualmente, y siendo esto así como lo cs, soy de parcecr que digais á esos senor á mí os enviáron que pues están en un fil las nores que á mi os cnvé, ó asolverle, que le dexen pasar libremente, pues siempre es alabado mas cl hacer bien, que mal, y esto lo diera firmado de mi nombre si supieque mal, y yo en este caso no he hablado de mip, siral firmar : y yo ch este camorin un precepto entre orros no que se me vino á la memoria un precepto entre otros muchos, que me dió mi amo Don Quixore la noche ántes que viniese á ser Gobcrnador desta Insula, que fué, tes que vindo la justicia estuviese en duda, me decantaque quanto ta justicia cstur se y acogiese a la misericordia, y ha qucrido Dios que agora se me acordase, por venir en este caso como de molde. Así es, respondió el mayordomo, y tengo para mi que el mismo Licurgo, que dió leyes á los Lacedemí que el misno Licurgo, que dió leyes a los lace aue el monios, no puctiera dar mor sentencia que da que el gran Panza ha dado, y acabcse con esto la audiencia desta mañana, y yo daré órden como el señor Gobernador comia muy á su gusto. Eso pido, y barras dereclias, dix Soncho denme de comer, y liucran casos y dudas sobre mí, que yo las despavilaré en cl ayre. CumTOM. IV. 
DON QUIXOTE DE IA MANCHA

plió su palabra el mayordomo, pareciéndole ser cargo de conciencia matar de hambre á tan discreto Gobernador, y mas que pensaba concluir con él aquella misma noche, haciéndole la burla última, que traia en comision de hacerle. Sucedió pues, que habiendo comido aquel dia contra las reglas y aforismos del Doctor Tirteafuera, al levantar de los manteles entró un corrco con una carta de Don Quixote para el Gobernador. Mandó Sancho al secretario que la leyese para sí, y que si no vinicse en ella alguna cosa digna de secreto, la leyese en voz alta. Hizolo así el secretario, y repasándola primero, dixo: bien se puede leer en voz alta, que lo que el scinor Don Quixote escribe á vuesa merced, merece estar estampado y escrito con letras de oro, y dice así :

Carta de Don Quixote de la Mancha á Sancho Panza, Gobernador de la Insula Barataria.

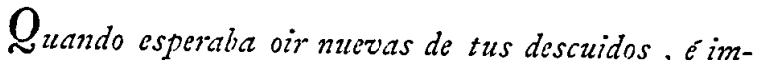
pertinencias, Sancho amigo, las oi de tus discreciones, de que di por ello gracias particulares al Cielo, el qual del esticirol sabi levantar los pobres, $y$ de los tontos hacer discretos. Dicenme que gobiernas como si fueses hombre, y que eres hombre, como si fueses bestia, segun es la humildad con que te tratas: y quicro que advicrtas, Sancho, que muchas veces conviene, y es necesario por la autoridad del oficio, ir contra la humildad del corazon, porque el buen adorno de a porsona que está puesta en graves cargos, ha de ser conformé á lo que ellos pidin, y no á la medida de lo que su humilde condicion le inclina. Vistete bien, que un
PARTEIT. CAPÍTULOLI.

palo compuesto no parece palo: no digo que traigas dixes, ni galas, ni que siendo juez te vistas como soldado, sino que te adornes con. el hábito que tu of cio requive, con tal que sea limpio y bien compuesto. Para ganatr la voluntad dil pueblo que gobiernas, ontwi otras has de hater dos cosas: lat una, ser bien criado con todos, anninge esto ja otra vez te lo he dicho, y la otra, procurar la abundancia de los mantenimiontos, que no haty cosa que mas fatigne el corazon de los pobres, que la hambre $y$ la carestia.

No hat $\sigma_{a}$ ms mechas pragmaiticas, y' si las hicieres, procura que sean buenas, y sobre todo que so guarrden y cumplan, que las pragrnaticas que no se guturdan, lo mismo es que si no lo fuesen; ántes dan á entendor, que el Principe que tuvo discrecion y auto ridad para hacerlas, no tuvo valor para hacer que se guardasen: $y$ las le'es que atemorizan, $y$ no se executan, vienen á ser como la wiga, Rey de las ranas, que al principio las espantó, y con el timpo la menostruciatron, ye subicron sobre ella. Sé padre de las vimtudes, y padrastro de los vicios. No seas siempre riguroso, ni siempre blando, y escoge el medio entre estos dos extremos, que en esto está el punto do la discrecion. Visita las cárceles, las carnecerias y las plazas a que la presencia dol Gobernador en lugares tales, es de mucha importancia. Consuela á los presos que esperan la brevedad de su despacho. Sé coco á los carniceros, que por entónces imualan los pesos, sé espantajo á las placeras por la misma razon. No te mutestres (aunque por ventura lo seas, lo qual yo no creo) codicioso, mugericgo, ni gloton ; porque in 
sabiendo el pueblo y los que te tratan tu inclinacion determinada por alli te darinz bateria hasta derribarte en el profundo de la perdicion. Mira y remira, pasa y repasa los conscjos y documentos, que te di por escrito ántes que de aqui partieses á tu (jobierno, 1' verás como hallas en cllos, si los guardas, una ajuda de costa, que to sobrelleve los trabajos $y$ dificultades, que á cada paso á los Gobernadores se les ofrecen. Escribe á tus serions, y mucostrateles agradecialo, que la ingratitud es hija de la soberbiaz, y uno de los mayores pecados que se sabe, y la persona aue es agradecida á los que bien lo han hecho, da indicio, que tambiun lo serí á Dios, que tantos bienes lo hizo, $y$ de contino le hace.

La señora Duquesa despachó un propio con tu vestido y otro presente á tu muger Teresa Panza: por momentos esperamos resjucsta. Yo he estado un poco mal dispuesto de un cierto gateamiento, que me sucedió no mu' a cucnto de mis narices; pero no fuc nada, que si hay cncantadores que me maltraten, tambion los hay que me defiendan. Avisame si el majordomo que estat contigo tuvo que ver cn las acciones de la Trifaldi, como tiu sospechaste, y de todo lo que te sucediere me iris dando aviso, pues es tan corto el camino, guanto mas que jo pienso dexar presto esta vida ocinsa en que estoy, pues no naci para ella. Un negocio se me ha of recido, que creo que me ha de poner en desgracia destos Seriores; pero aunque se me da mucho, no se me da nada, pues en fin en fin tengo de cumplir ántes con mi profision, que con su gusto, conforme á lo que suele decirse: amicus Plato, sed magis amica veritas. Digote este latin, porque me doy á entender, que despues que eres Gobernador lo habrás aprendido. $Y$ á Dios, el qual te guarde de que ninguno te tenga lástima.

Tu amigo

Don . Quixote de la Mancha.

Oyó Sancho la carta con mucha atencion, y fué celebrada, y tenida por discreta de los que la oyćron, y luego Sancho se levantó de la mesa, y llamando al secretario, se encerró con él en su estancia y sin dilatarlo mas, quiso responder luego á su señor Don Quixote: y dixo al secretario, que sin añadir, ni quitar cosa alguna fuese escribiendo lo que él le dixese, y así lo hizo, y la carta de la respuesta fué del tenor siguiente:

Carta de Sancho Panza á Don Quixote de la Mancha.

$L_{a}$ ocupacion de mis negocios es tan grande, que no tengo lugar para rascarme la cabeza, ni aun para cortarme las uñas, y asi las traigo tan crecidas qual Dios lo remedie. Digo esto, señor mio de mi alma, porgue vuesa merced no se espante, si hasta agora no he dado aviso de mi bien, ó mal estar en este Gobierno, en el qual tengo mas hambre que quando andábamos los dos por las selvas y por los despoblados.

Escribióme el Dugue mi señor el otro dia, díndome aviso, que habian entrado en esta Insula ciertas espias para matarme, y hasta agora yo no he descubierto otra que un cierto Doctor, que está en este Lugar asalariado para matar á quantos Gobernado- 
res aquí vinieren: llámase el Doctor Pedro Recio, y es natural de Tirteafuera, porque vea vuesa merced, que nombre para no temer que he de morir. á sus manos. Este tal Doctor dice él mismo de si mismo, que el no cara las enfermedades quando las hay, sino que lats previene para que no vengan, y las medecinas que usa son diet a y mas dieta, hasta poner la persona en los huesos mondos, como si no fuese mayor mal la flaqueza, que la calentura. Finalmente él me va matando de hambre, y yo me voy muriendo de despecho, pues quando pensé venir á este Gobierno á comer caliento y á beber frio, y á recrear el cuerpo entre sábanas do olanda sobre colchones de pluma, he venido al hace penitencia, como si fuera ermitaño, y como no la hat go de mi voluntad, pienso que al cabo al cabo me ha de llevar el diablo.

Hasta agora no he tocado derecho, ni llevado cohecho, y no puedo pensar en que va esto, porque aqui me han dicho que los Gobernadores que á esta Insula suelen venir, ántes de entrar en ella, ó lis han dat do ó les han prestado los del pueblo muchos dineros, y que esta es ordinaria usanza en los demas que van a' Gobiernos, no solamente en este.

Anoche andando de ronda, topé una muy hermosa doncella en trage de varon, y un hermano suyo on hábito de mueger: de la moza se enamoró mi maestresala, y la escogió en su imaginacion para su muger. segun el ha dicho, y yo escogi al mozo para mi yerno. hoy los dos pondrémos en plática nuestros pensamientos con el padre de entrambos, que es un tal Diego de Llana, hidalso y christiano viejo quanto se quiere.
Yo wisito las plazas, como vuesa merced me lo aconseja, y ayer hallé una tendera que vendia avellanas muevas, $y$ averigiucle que habia mezclado con una hanega de avellanas nuevas otra de viejas, vanas y podridas: apliquélas todas para los ninos de la doctrina, que las sabrian bien distinguir, y sentenciela que por quince dias $n o$ entrase en la plaza: hanme dicho que lo hice valerosamente, lo que sé decir á vuesa merced es, que es fama en este pueblo, que no hay gente mas mala que las placeras, porque todas son desvergonzadas, desalmadus y atrevidas, $y$ yo asi lo croo por las que he visto en otros pucblos.

De que mi serĩora la Duquesa haja escrito á mi muger Teresa Panza, y enviadole el presente que vuesa merced dice, estoy muy satisfecho, y procuraré de mostrarme agradecido á su tiempo : bésele vuesa merced las manos de mi parte, diciendo que digo yo, que 220 lo ha echado en saco roto, como lo vera por la obra. No querria qui vuesa merced tuvicse trabacuentas de disgusto con esos mis señores, porque si vuesa merced se enoja con ellos, claro está que ha de redundar en mi daño, y no será bien, que pues se me da á mi por consejo que sea agradecido, que vuesa merced no lo sea con quien tantas mercedes lo tiene hechas, y con tanto regalo ha sido tratado en su castillo.

Aquello del gateado no enticndo; pero imatgino que debe de ser alguna de las malas fechoriass que con vuesa merced stielen usar los malos encantadores, yo lo sabré quando nos veamos. Quisiera enviarle á vutesa mercid alsunna cosa; pero $n 0$ sé que envic, sino es al- 
154

DON QUIXOTE DE LA MANCHA

gunos canutos de aeringas, que para con vexiaas los gucen on esta Tusula muy curiosos aungue si mo dura el oficio, yo buscaré que cnviar de haldas, óde mangas. Si me escribiere mi muger Teresa Panza, pague vussa merced el porte, y cnvieme la carta, que tengo grandisimo desen de saber del estado de mi casa do mi muger $y$ de mis hijos. $Y$ con esto Dios libre á vne sa merced de mal intencionados encantadores oy á mi me saque con bien y en paz deste Gobierno, que lo dudo porgue le pienso dexar con la vida, segun me trata el Doctor Pedro Recio.

Criado de vulesa merced Sancho Panza el Gobernador.

Cerró la carta el secretario, y despachó luego al correo, y juntándose los burladores de Sancho, diéron órden entre sí como despacharle del Gobierno, y aquella tarde la pasó Sancho en hacer algunas ordenanzas tocantes al buen Gobicrno de la que él imaginaba ser Insula, y ordenó, que no hubiese regatones de los bastimentos en la República, y que pudiesen meter en ella vino de las parce que quisiesen, con aditamento que declarasen el Lugar de donde cra, para ponerle el precio segun su estimacion, bondad y fama, y el que lo aguase, ó le mudase el nombre, perdicse la vida por ello : moderó el precio de todo calzado, principalmente cl de los zapacos, por pareccrle que corria con exôrbitancia: puso tasa en los salarios de los criados que caminaban á rienda suclta por el camino del interese: puso gravísimas penas a los que cantasen cantares lascivos y descompuestos, ni

PARTEIT. CAPfTULOLT.

de noche ri de dis: ordenó que ningun cieco cantase milagro en coplas, si no truxese testimonio auténtico de ser verdadero, por parecerle que los mas que los ciegos cantan son fingidos en perjuicio de los verdaderos.

Hizo y creó un alguacil de pobres, no para que los persiguiese, sino para que los cxâminase si lo eran, porque á la sombra de la manquedad fingida y de la llaga falsa, andan los brazos ladrones y la salud borracha. En resolucion él ordenó cosas tan buenas, que hasta hoy se guardan en aquel Lugar, y se nombran : Las constituciones del gran Gobernador Sancho Panza.

\section{CAPITULO LII.}

Donde se cuenta la aventura de la segunda Dueña Dolorida ó Angustiada, llamada por otro nombre Doña Rodriguez.

Cuenta Cide Hamete, que estando ra Don Quixote sano de sus aruños, le pareció que la vida que en aquel castillo tenia era contra toda la órden de caballería que profesaba, y así determinó de pedir licencia á los Duques para partirse á Zaragoza, cuyas ficstas estaban cerca, adonde pensaba ganar el arnes, que en las tales fiestas se conquista. $Y$ estando un dia á la mesa con los Duques, Y comenzando á poner en obra su intencion y pedir la licencis, reis aquí á deshora entrar por la puerta de la gran sala dos mugeres, como despues parcció, cubiertas de luto de los pies á la cabcza, y la una dellas llegándose á Don Quixote, se le echó á los pies, tendida de largo á largo , la boca cosida con los pies de Don Quixote, $y$ daba unos gemidos tan tristes, tan profundos y tan rom 
dolorosos, que puso en confusion á todos los que la oian y miraban : $y$ aunque los Duques pensáron que seria alguy burla que sus criados querian hacer á Don Quixote, todaría viendo con el ahinco que la muger suspiraba, gemia y lloraba, los tuvo dudosos y suspensos, hasta que Don Quixote compasivo la levantó del suelo, $y$ hi zo que se descubriese y quitase el manto de sobre la faz lloros. Ella lo hizo así y mostró ser lo que jamas se pudiera pensar, porque descubrió el rostro de Doña Rodrigucz, la dueña de casa : y la otra enlutada era su hiia la burlada del hijo del labrador rico. Admiráronse todos aquellos que la conocian, y mas los Duques que ninguno, que puesto que la tenian por boba, $y$ de buena pasta, no por tanto, que viniese a hacer locuras. Finalmente Doña Rodriguez, volviéndose á los Señores les dixo. Tuesas Eicelencias sean servidos de darme licencia que ro departa un poco con este caballero, porque así conviene para salir con bien del negocio en que me ha puesto el atrevimiento de un mal intencionado villano. E1 Duque divo que él se la daba, y que departicse con el enderezando la voz y el rostro á Don Quixote, dixo: dias ha, valcroso caballero, que os tengo dada cuenta de la sinrazon $\mathrm{y}$ alerosiz que un mal labrador tiene fecha a mi muy querida y amada fija, que es esta desdichada que aquí está presente, y ros me habédes prometido de volver por ella, enderczándole el tuerto que le tienen fecho, $\mathrm{y}$ agora ha llegado á mi noticia, que os querédes partir deste castillo en busca de las buenas venturas que Dios os depare : y así querria que ántes que os escurriésedes por esos caminos, desafísedes á este rús- tico indómito, $y$ lc hiciésedes que se casase con mi hija, en cumplimiento de la palabra que le dió de ser su esposo, íntes y primero que yogase con ella, porque pensar que el Duque mi scñor me ha de hacer justicia, es pedir peras al olmo, nor la ocasion que ya á vuesa merced en puridad tengo declarada: y con esto nuestro Señor dé á vucsa merced mucha salud, y á nosotras no nos desampare. A cuyas razones respondió Don Quixote con mucha gravedad y prosopopeya : buena ducña, templad vuestras lágrimas, ó por mejor decir, enxugadlas, y ahorrad de vuestros suspiros, que yo tomo á mi cargo el remedio de ruestra hija á la qual le hubiera estado mejor no haber sido tan fácil en creer promesas de enamorados, las quales por la mayor parte son ligeras de prometer, $y$ muy pesadas de cumplir : $y$ asi con licencia del Duque mi señor, yo me partiré luego en busca dese desalmado mancebo, y le hallaré , y le desafiaré, y le mataré cada y quando que se excusare de cumplir la prometida palabra : que el principal asunto de mi profesion es perdonar á los humildes, y castigar á los soberbios: quiero decir, acorrer á los miscrables, $y$ destruir á los rigurosos. No es menester, respondió el Duque, que vuesa merced se ponga en trabajo de buscar al rústico, de quien esta buena dueña se queja, ni es menester tampoco que vuesa merced me pida á mí licencia para desafiarle, que yo le doy por desafiado, y tomo á mi cargo de hacerle saber este desafio, $y$ que le acete, $y$ venga á responder por sí á este mi castillo, donde á entrámbos daré campo seguro, guardando todas las condiciones que en tales actos suelen, y deben guardarse, guardando igualmente su justicia á cada uno, como están obligados á guardarla to- 
I 58

DON QUIXOTE DE LA MANCHA

dos aquellos Príncipes, que dan campo franco á los que se combaten en los términos de sus señoríos. Pues con cse seguro, y con buena licencia de Vuesa Grandeza, replicó Don Quixote, desde aquí digo, que por csta vez renuncio mi hidalguía, y me allano y ajusto con la llaneza del dañador, y me hago igual con ćl, habilitándole para poder combatir conmigo, $y$ asi , aunque ausente, le desafio $y$ repto en razon de que hizo mal en defraudar á esta pobre, que fué doncella, y ya por su culpa no lo es, y que le ha de cumplir la palabra que le dió de ser su legítimo esposo, ó morir en la demanda. Y lucgo descalzándose un gruante, le arrojó cn mitad de la sala , y el Duque le alzó, diciendo, que, como ya habia dicho, él acctaba cl tal desafío en nombre de su vasa1lo, y señalaba el plazo de allí á scis dias, y el campo en la plaza de aquel castillo, y las armas las acostumbradas de los caballeros, Ianza y cscudo, y arnes tranzado con todas las demas piczas, sin engaño, superchería, ó supersticion alguna, exâminadas y vistas por los jueces del campo; pero ante todas cosas es menester que esta buena dueña y esta mala doncella pongan el derecho de su justicia en manos del señor Don Quixote, que de otra mancra no se hará nada, ni llegarí á debida cxecucion el tal desafio. Yo sí pongo, respondió la dueña : y yo tambien, añadió la hija, toda llorosa y toda vergonzosa y de mal talante. Tomado pues cste apuntamiento, y habiendo imaginado cl Duque lo que habia de hacer en el caso, las cnlutadas se fućron, y ordenó la Duquesa que de allí adelante no las tratasen como á sus criadas, sino como á Scñoras aventureras, que venian á pedir justicia á su casa, y así les diéron quarto á parte, y
PARTEIT. CAPITULO IIT.

las sirviéron como á forasteras, no sin espanto de las demas criadas, que no sabian en que habia de parar la sandez y desenvoltura de Doña Rodriguez, y de su mal andante hija. Estando en esto, para acabar de regocijar la fiesta, y dar buen fin á la comida, veis aquí donde entró por la sala el page que llevó las cartas y presentes á Teresa Panza, muger del Gobernador Sancho Panza, de cuya llegrada recibiéron gran contento los Duques, deseosos de saber lo que le habia sucedido en su viage, y preguntándoselo, respondió el page, que no lo podia decir tan en público, ni con breves palabras, que sus Excelencias fuesen servidos de dexarlo para á solas, y que entretanto se entretuviesen con aquellas cartas, y sacando dos cartas las puso en manos de la Duquesa, la una decia en el sobrescrito: Carta para mi Señora la Duquesa tal de no sé donde, y la otra: $A$ mi marido Sancho Panza Gobernador de la Insula Barataria, que Dios prospere mas años que á mi. No se le cocia el pan, como suele decirse, á la Duquesa hasta leer su carti, y abriéndola y leido para sí, y viendo que la podia leer en voz alta, para que el Duque y los circunstantes la oyesen, leyó desta manera:

CARTA DE TERESA PANZA A LA DUQUESA.

Mucho contento me dió, señora mia, la carta que Vuesa Grandeza me escribió, que en verdad que la tenica bien deseada. La sarta de corales es muy buena, y el vestido de caza de mi marido no le va en zaga. De que Vuestra Señoria haya hecho Gobernador á Sancho mi consorte, hat recibido mucho gusto todo este Lugar, 

ra y Maese Nicolas el Barbero y Sanson Carrasco el Bachiller ; pero á mi no se me da nada, que como ello sea asi , como lo es, diga cada uno lo que quisiere, aunque si va á decir verdad, á no venir los corales $y$ el vestido, tampoco yo lo crejera, poraue en este pucblo todos tienen á mi marido por un porro, y gue sacado de gobernar un hato de cabras, no pueden imaginar para que gobierno pueda ser bueno: Dios lo hage lo oncanine como we guc lo han menester sus hijos. cencia de vuesa merced, de meter este buen dia en mi casa, yéndome á la Corte á tenderme en an coche, patra aucbrar los ojos á mil envidiosos que y'a tengo:y asi suplico á Vuestra Excelencia, mande á mi marido me envic algun dinerillo, y' que sea algo que, porque en la Corte son los gastos grandes, que el pan iale á real $\gamma$ la carne la libra á treinta maravedis, que es un juicio, y si quisicre que no vaya, que me lo avise con ticmpo, porque me están bullendo los pies por ponerme en camino, que me dicen mis amigas $y$ mis vecinas, que si jo y mi hija andamos orondas $y$ promposas on la Corto vendrí í ser conocido mi ma rido por mi, mas que yo por cil, siendo for zoso que pregunten muchos: ¿quicu son estas Señoras deste co che? y un criado mio responderá: la muger y la hija de Sancho Panza cjoburnator de la Insula barataria, y desta manera será conocido. Sancho, y jo sere estimada, y á Roma por todo. P'isame quanto pesarme puede, que este año no se han cogido bellotas en este pueblo, con todo eso envio á Vuestra Alteza hasta medio celemin, que una á ana las fui $y^{\prime o ~ a ́ ~ c o g e r ~} y$ á escoger al monte y no las halli mas mayores, yo quisiera que fueran como hatevos de avestruz.

No se lo olvide á vuestra pomposidad de escribirme, que jo tendré caidado de la respmesta, avisando de mi salut, $y$ de todo lo que hubiere que avisar deste Lngar , donde quedo rogando á nuestro Serior guarde a buestra Grandeza, y á mí no olvide. Sancha mi hija, y mi hijo besan á vucesa merced las manos.

La que ticne mas deseode ver á $V$. $S$. que de escribirlat

\section{Sa criada Teresa Panza.}

Grande fuć el gusto que todos recibiéron de oir la carta de Teresa l'anza, principalmente los Duques: y la Duquesa pidió parecer á Don Quixote, si seria bien abrir la carta que renia para el (iobernakior, que imaginaba debia de ser bonísima. Don Quixote dixo que él la abriria por darles gusto, y así lo liizo, y vió que decia desta manera :

CARTA DE TERESA PANZA A SANCHO PANZA SU MARIDO Tu carta recibi, Sancho mio de mi alma, y yo te prometo $y^{\prime}$ juro, como católica christiana, que no faltá ron dos dedos para volverme loca de contento. Mira, hermano, quando yo lle gué á oir que eres Gobernador, me pensé alli caer muerta de puro gozo, que ya sabes tí que dicen, que asi mata la alegrica suibita, como c dolor grande. A Sanchica tu hija se le fuciron las aguas rom. 1 v. 
DON QUIXOTE DE LA MANCHA

sin sentivlo de puro contento. El vestido que me enviaste tenia delante, $y$ los corales que me envió mi scrióra la Duquesa al cuello, y las cartas en las manos, y el portador dellas alli presente, y con todo eso creia y pensaba, que era todo sueño lo que veia y lo que tocaba, porque aquien podia pensar que un pastor de cabras labia de venir á ser Gobernador de Instulas? Ya sabes tii, amigo, que decia mi madre que era menester vivir mucho para ver mucho: digolo , porque pienso ver mas, si vivo mas, porque no pienso paratr hasta verte arrendador, ó alcabalero, que son oficios que anungue lleva el diablo á quion mal los usat an fin que an siempre tienen y manejan dineros. Mi suriora lat Duquesa te dircí el deseo que tengo de ir à lix Corte: mirate en ello, $y$ avisame de tu gusto, que go procurare honrarte en ollat, andando on coche.

El Cura el Barbero, el Bachiller y aun el Sacristan, no pueden creer que eres Gobernador, $y$ dicen que todo es embeleco, ó cosas de encantamento, como son todas la de Don Ouixote tu amo, y dice Sanson que ha de ir á buscarte y á sacarte el Gobierno de la cabeza, y á Don Quixote la locura de los cascos: jo no hago sino reirme, y mirar mi sarta, $y$ dar traza del vestido que tengo de hacer del tujo á nutestra hija. Unas bellotas envió á mi seriora la Duquesa, yo quisiera que fucran de oro. Enviame tú algunats sartas do perlas, si se usan en esa Ínsula. Las nuevas deste Lugar son, que lat Berrueca casó í su hija con un pintor de mala mano, que llegó á este pucblo á pintar to que saliese. Mundóle el Concejo pintar las armas de Sil Magestad sobre las puertas dil Ajuntamionto,
PARTEIT. CAPITULO III.

pidió dos ducados, diéronselos adelantados, trabajo ocho dias, al cabo de los quales no pintó nada, $y$ diro que $n o$ acertaba á pintar tantas baratijas: volvió el dinero y con todo eso se casó á tituclo de buen oficial: verdad es, que ya ha dexado el pincel, y tomado el azada, $y$ va al campo como gentilhombre. El hijo de Pedro de Lobo se ha ordenado de grados y corona, con intencion de hacerse clórigo : súpolo Minguilla, la nilta de Mingo Silvato, y hale puesto demanda de que la tiene dada palabra de casamiento: malas lenguas quieren decir que ha estado en cinta del; pero el lo niega á pies juntillas. Oganio no hay acoytunas, ni se halla una gota de vinagre en todo este pueblo. Por aquí pasó una companiai de soldados, lleváronse de camino tres mozas deste pueblo: no te quiero decir quicn son, quizá volvorán, y no faltará quien las tome por mugeres, con sus tachas bucnas, ó malas. Sanchica hace puntas de randas, gana cada dia ocho maravedis horros, que los vi echando en una alcancía para aruda á su axuar ; pero ahora que es hija de un Gobernador, tú le darás la dote, sin que ella lo trabaje. La fuente de la plaza se secó: an rajo cayó en la picota, y alli me las den todas. Espero respuesta desta, y la resolucion de mi ida á la Corte: $y$ con esto Dios te me guarde mas años que á mi , ó tantos, porque no querria dexarte sin mí en este mundo.

\section{Tu muger Teresa Panza.}

Las cartas fuéron solenizadas, reidas, estimadas y admiradas, y para acabar de echar el sello, llegó el correo,

TOM. Iv. $\mathrm{x}$ ij 
164

DON QUIXOTE DE LA MANCHA

el que traia la que Sancho enviaba á Don Quixote, que asimesmo se leyó públicamente, la qual puso en duda la sandez del Gobernador. Retiróse la Duquesa para saber del page lo que le habia sucedido en el Lugar de Sanber de par extenso, sin dexar cho, el qual se lo cono muy póle las bellotus, y mas circunstancia que no refiricse: diole las belloras, y mas un queso, que Teresa le dió por ser muy bueno, que se aventajaba á los de Tronchon : recibiólo la Duquesa con grandísimo gusto, con el qual la dexarémos, por con gra contar el fin que tuvo el Gobierno de

\section{CAPÍTULO LIII.}

Del fatigado fin y remate, que tuvo el Gobierno de Sancho Panza.

Pensar que en esta vida las cosas della han de durar Censar en lo excusado ; úntes sempre en un esta, cs penar en lo cyico í la redonparece que clla anda todo en redondo, digo a la redonda. La primavera sigue al verano, el verano al estio el estio al otoño, y el otoño al invierno, y cl invier no a la primero. Y oś torna á andarse el tiempo con

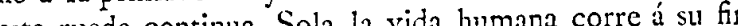
ligera, mas que el tiempo, sin esperar renovarse, sino es en la orra, que no tiene términos que la limiten. Esto dice Cide Hametc, Filósofo mahomético, porque esto de entender la ligcreza, é instabilidad de la vida presente; y de la duracion de la cterna que se espera, muchos sin lumbre de fe, sino con la luz natural, lo han entendido; pero aquí nuestro autor lo dice por la presteza con que se acabó, se consumió, se deshizo, se fué
PARTEII. CAPÍTULOLIII.

como en sombra y humo el Gobierno de Sancho, el qual estando la séptima noche de los dias de su Gobierno en su cama, no harto de pan, ni de vino, sino de juzgar y dar parcceres, y de hacer estatutos y pragmáticas, quando el sueño á despecho y pesar de la hambre, le comenzaba á cerrar los párpados, oyó tan gran ruido de campanas y de voces, que no parecia sino que toda la Ínsula se hundia. Sentóse en la cama, y estuvo atento y escuchando, por ver si daba ent la cuenta de lo que podia ser la causa de tan grande alboroto; pero no solo no lo supo, pero añadiéndose al ruido de voces y campanas el de infinitas trompetas y atambores, quedó mas confuso y lieno de temor y espanto, y levantándose en pic, se puso unas chinelas por la humedad del suelo, $y$ sin ponerse sobreropa de levantar, ni cosa que se pareciese, salió á la puerta de su aposento á ticmpo, quando vió venir por unos corredores mas de veinte personas con hachas encendidas en las manos, y con las espadas desenvaynadas, cendidas en las manos a grandes roces: arma, arma, señor Gobernador, arma, que han entrado infinitos enemigos en 12 Insula, y somos perdidos, si vuestra "industria y valor no nos socorre. Con este ruido, furia y alboroto llegáron donde ${ }^{27}$ Sancho estaba atónito y embclesado de lo que oia y veia, y quando llegíron á él, uno le dixo: ármese luego Vuestra Señoría, si no quiere perderse, y que toda esta Insula se pierda.:Que me tengo de armar? que toda esta frsula se pierda. 'Que me ten respondió Sancho ¿̨ni que sé yo de armas, ni de socorros? Estas cosas mejor será dexarlas para mi amo Do Quixote, que en dos paletas las despacharí, y pondra en cobro, que yo, pecador fuí á Dios, no se me entiende nada destas priesas. $\mathrm{H}_{2}$, señor Gobernador, dixo otro 
¿que relente es ese? ármese vuesa merced, que aquí le rraemos armas ofensivas y defensivas, y salga á esa pla$z a$, y sea nuestra guia y nuestro Capitan, pues de derecho le toca el serlo, siendo nuestro Gobcrnador. Ármenme norabuena, replicó Sancho, y al momento le truxéron dos paveses, que venian proveidos dellos, y le pusiéron encima de la camisa, sin dexarle tomar otro vestido, un paves delante, y otro detras, $y$ por unas concavidades que traian hechas, le sacáron los brazos, y le liúron muy bien con unos cordeles, de modo que quecó empredado y entablado, derecho como un huso, sin poder doblar las rodillas, ni mencarse un solo paso. Pusiéronle en las manos una lanza, á la qual se arrimó para poder tenerse en pie. Quando asi le tuvieron, le dixeron, que caminase, y los guiase, y animase á todos, que siendo él su norte, su lanterna y su lucero, tendrian buen fin sus negocios. Como tengo de caminar, desventurado yo, res. pondió Sancho, que no puedo jugar las choquezuelas de Jas rodillas, porque me lo impiden estas tablas, que tan me lo inpiden eas has te hacer es llevarme en brazos, y ponerme atravesado, ó en pie en algun postigo, que yo le guardaré , ó con esta lanza, ó con mi cuerpo. Ande, señor Gobernador, dixo otro, que mas el miedo que las tablas le impiden el paso: acabe, y menéese, que es tarde, y los enemigos crecen, y las voces se aumentan, y el peligro carga. Por cuyas persuasiones $y$ vituperios probó el pobre Gobernador á moverse, y fué dar consigo en el suelo ran gran golpe, que penso que se habia hecho pedazos. Quedó como galápago encerrado y cubierto con sus conchas, ó como medio tocino, metido entre dos artesas, ó bien así como barca, que da

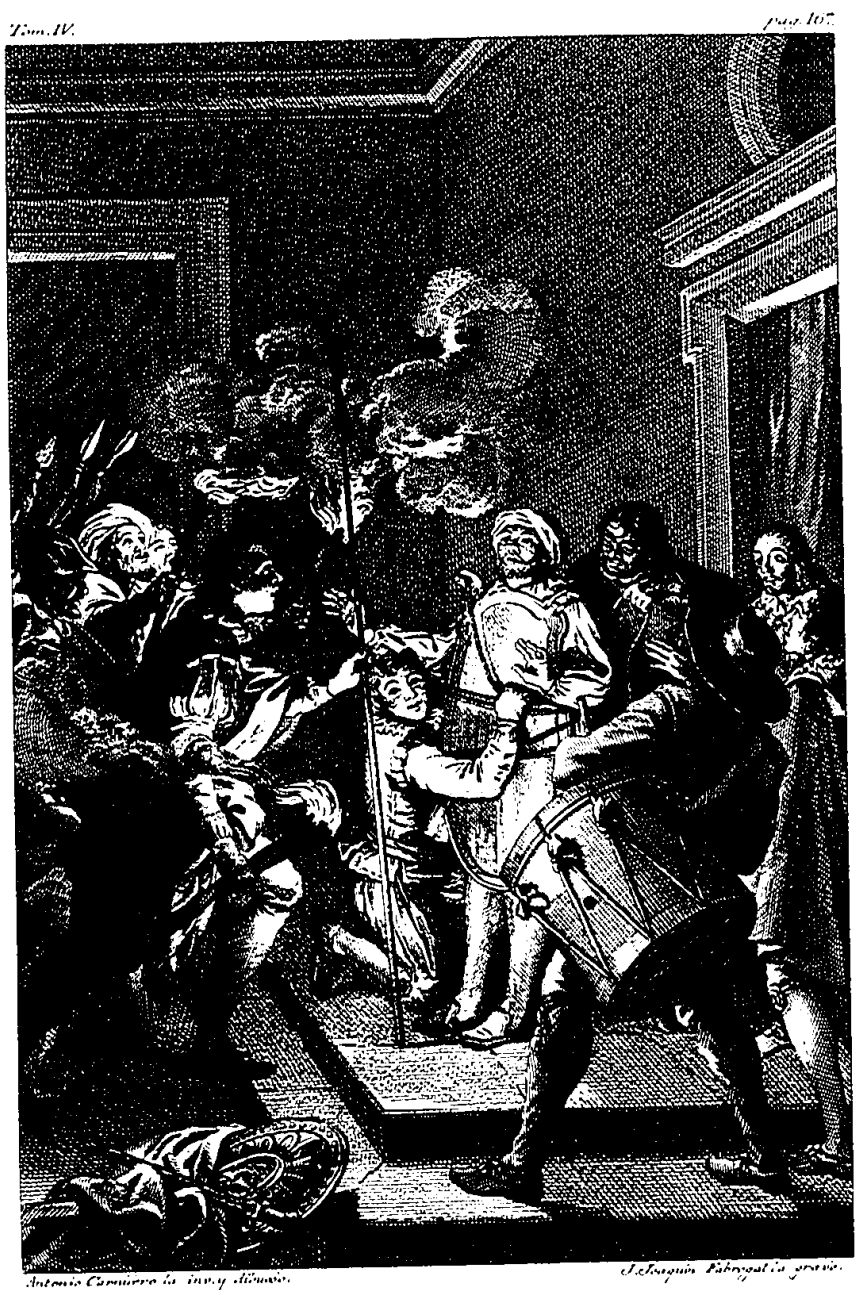


al traves en la arena: y no por verle caido aquella gente burladora le tuviéron compasion alguna ; ántes apagando las antorchas tornáron á reforzar las voces, $y$ á reiterar el arma con tan gran priesa, pasando por encima del pobre Sancho, dándole infinitas cuchilladas sobre los pareses, que si él no se recogiera y encogiera, mericndo 1a cabeza entre los paveses, lo pasara muy mal el pobre Gobernador, el qual en aquella estrecheza recogido, sudaba y trasudaba, $y$ de todo corazon se encomendaba á Dios, que de aquel peligro le sacase. Unos tropezaban en él, orros caian, y tal hubo, que se puso encima un buen espacio y desde allí como desde atalaya gobernaba los exércitos, y á grandes voces decia : aquí de los nuestros, que por esta parte cargan mas los cnemigos: aquel portillo se guarde, aquella puerta se cierre, aque1 las escalas se tranquen, vengan alcancías, pez y resina en coldor de accyte ardiendo, trínchense las calles con colchones. En fin él nombraba con todo ahinco todas las ba ratijas, é instrumentos y pertrechos de guerra, con que suele defenderse el asalto de una ciudad, y el molido Sancho que lo escuchaba y sufria todo, decia entre sí: ¡ó si mi Señor fuese servido que se acabase ya de perder esta Ínsula, y me viese yo, ó muerto, ó fucra desta grande angustia! Oyó el Cielo su peticion, y quando ménos lo esperaba oyó voces que decian : vitoria, vitoria, los encmigos van de vencida: ea, señor Gobernador, levántese vuesa merced, y venga á gozar del vencimiento $y$ á repartir los despojos que se han tomado á los to , y a repartir los despojos que enemigos por el valor dese invencible brazo. Levintenme, dixo con roz doliente el dolorido Sancho. Ayudáronle á levantar, y puesto en pie dixo: el cnemigo que 
0 hubierc vencido, quiero que me le claven on la frenis : yo no quiero repartir despojos de cnemigos, sino peVir y suplicar á algun amigo, si es que le tengo', que ne dé un trago de vino, que me seco, y me cnxugue este sudor, que me hago agua. Limpiáronle, truxéronle cl vino, desliáronle los paveses, sentóse sobre su lecho, desmayóse del temor, del sobresalto y del trabajo. Ia les pesaba á los de la burla de habérscla hecho tan pesada; pero el haber vuelto en sí Sancho, les templo pena que les habia dado su desmayo. Pregunto que hora cra: respondiéronle, que ya amanecia. Cilló, y sin decir otra cosa, comenzó á vestirse todo sepultado en silencio, y todos le miraban, y esperaban en que habia ic parar la priesa con que se vestia. Vistióse en fin, y poco á poco, porque estaba molido, y no podia ir mucho á mucho, se fué á la caballcriza, siguiéndole todos los que allí se hallaban, y llegándose al rucio, le abrazó, y le dió un beso de paz en la frente, y no sin lágrimas en los ojos le dixo : venid vos aca, compañero mio, $y$ amigo mio, $y$ conllevador de mis trabajos $y$ mi serias, quando yo me avenia con vos, y no tenia otros pansamientos que los que me daban los cuidados de remendar vuestros aparejos, $y$ de sustentar vuestro corpezuclo, dichosas eran mis horas, mis dias y mis años; $\mathrm{pc}$ ro despues que os dexé , y me subí sobre las torres de la ambicion y de la soberbia, se me han entrado por el alma adentro mil miscrias, mil trabajos y quatro mil desasosiegos. $Y$ en tanto que estas razones iba diciendo, iba asimesmo enalbardando el asno, sin que nadie nada le dixese. Enalbardado pues el rucio, con gran pena y pesar subió sobre él, y encaminando sus palabras y razo- nes al mayordomo, al secretario, al maestresala y á ledro Recio el Doctor y á orros muchos que allí presentes estaban, dixo : abrid camino, señores mios, $y$ de xadme volver á mi antigua libertad: dexadme que vaya a buscar la vida pasada, para que me resucite desta muerte presente. Yo no nací para Gobernador, ni para defender Insulas, ni ciudades de los enemigos que quisieren acomcterlas. Mejor se me entiende á mí de arar y cavar, podar y ensarmentar las vinas, que de dar leyes, ni de defender Provincias, ni Reynos. Bien se está San Pe dro en Roma, quiero decir, que bien se está cada uno usando el oficio para que fué nacido. Mejor me está mí una hoz en la mano, que un cetro de Gobernador: mas quicro harrarme de gazpachos, que estar sujeto á la miseria de un médico impertinente, que me mate de hambre, y mas quiero recostarme á la sombra de una encina en el verano, y arroparme con un zamarro de dos pelos en el invierno en mi libertad, que acostarme con la sujecion del Gobierno entre sábanas de olanda, y vestirme de martas cebollinas. Vuesas mercedes se quecien con Dios, y digan al Duque mi señor, que desnudo nací, desnudo me hallo, ni pierdo, ni gano : quiero decir, que sin blanca entré en este Gobicrno, y sin ella salgo, bien al reves de como suelen salir los Gobernadores de otras İnsulas: y apártense, déxenme ir, que me voy á bizmar, que creo que tengo brumadas todas las costillas: merced á los encmigos que esta noche se han paseado sobre mí. No ha de scr así, scñor Gobernador, dixo el Doctor Recio, que yo le daré á vuesa mereed una bebida contra caidas y molimientos, que luego le vuelva en su prístina entereza y vigor, $y$ en lo de la rorr. iv. 
170

DON QUTXOTE DE LA MANCHA

comida yo prometo á vuesa merced de enmendarme, dexándole comer abundantemente de todo aquello que quisiere. Tarde piache, respondió Sancho: así dexaré de irme como volverme Turco. No son estas burlas para dos reces. Por Dios que así me quede en este, ni admita orro Gobicrno, aunque me le diesen entre dos platos, como volar al ciclo sin alas. Yo soy del linage de los Panzas que todos son testarudos, y si una vez dicen nones, zas, que todos son cesarudos, ys si una vá pecar de todo nones han de ser cl mundo. Quédense en esta caballeriza las alas de la hormiga, que me levantáron en el ayre, para que me comiesen vencejos y otros páxaros, y volvámonos á andar por el suclo con pie llano, que si no le adornaren zapatos picados de cordoban, no le faltarán alpargatas toscas de cuerda: cada oreja con su pareja, y nadie tienda mas la pierna de quanto fuere larga la sábana: y déienme par, que se me hace tarde. Á lo que cl mayordomo dixo: señor Gobernador, de muy buena gana dexáramos ir á vuesa merced, puesto que nos pesará mucho de perderle, que su ingenio y su christiano proceder obligan á desarle ; pero ya se sabe que todo Gobernador cstá obligado, ántes que se auscnte de la parte donde ha gobernado, á dar primero residencia : déla vucsa merced de los dicz dias que ha que tiene el Gobierno, y merced dió Suncho, sino es quien ordenare el Duque mi señor: yo voy á verme con él, yá él se la daré de molde: quanto mas, que saliendo yo desnudo, como salgo, no es mas que salic jo gobernado como un Ángcl. Par Dios que tiene razon el gran Sancho, dixo el Doctor Recio, y que soy de parecer
PARTEII. CAPITUIO IIV.

que le dexemos ir, porque el Duque ha de gustar infirito de verle. Todos viniéron en cllo, y le dexáron ir ofreciéndole primero companía, y todo aquello que quisiesc para el regalo de su persona y para la comodidad de su viage. Sancho dixo, que no queria mas de un poco de cebada para cl rucio, y medio queso y medio pan para él, que pues cl camino era tan corto, no habia menester mayor, ni mejor repostería. Abrazáronle todos, y ćl llorando abrazó á todos , y los dexó admirados, así de sus razones, como de su determinacion tan resoluta $\mathrm{y}$ tan discreta.

\section{CAPITULO LIV.}

Que trata de cosas tocantes á esta historia, y no á otra alguna.

Resolviéronse el Duque y la Duquesa de que el desafio que Don Quixote hizo á su vasallo por la causa ya referida pasase adelante, y puesto que el mozo estaba en Flándes, adonde se habia ido huyendo, por no tener por suegra á Doña Rodriguez, ordenáron de poner en su lugar á un lacayo Gascon, que se llamaba Tosílos, industriándole primero muy bien de todo lo que habia de hacer. De allí á dos dias dixo el Duque á Don Quixote, como desde allí á quatro vendria su contrario, y se presencaria en el campo, armado como caballero, $y$ sustentaria como la doncella mentia por mitad de la barba, y aun por toda la barba entera, si se afirmaba que él le hubiese dado palabra de casamiento. Don Quixote recibio mucho gusto con las tales nuevas, y se prometió asimismo de hacer maravillas en el caso, y tuvo á gran ventura habérsele ofrccido ocasion donde aquellos Señores puтом. 1v. 
172

DON QUTXOTE DE LA MANCHA

diesen ver hasta donde se extendia el valor de su poderoso brazo: $y$ asi con alborozo, $y$ contento esperaba los quatro dias, que se le iban haciendo á la cuenta de su quatro dias, que sexémoslos pasar nosotros, deseo quatrocientos siglos Dexér y vamos acompaña como dexamos pasar otras cosas á Sancho, que entre alegre y triste venia caminando sobre el rucio á buscar á su amo, cuya compañía le agradaba mas, que ser Gobernador de todas las Insulas del daba mas, que ser Gobernador habiéndose alongado mumundo. Sucedio pues, que no habiendose alongado mucho de la Insula del su ¿ averiguar si cra Insula, Ciudad, Villa, ó Lugar la que gobernaba) vió, que por el camino por donde él que gobir on bordones, destos exba venian seis peragna los quales en trangeros que piden la limosna cantando, los quales en llegando á él se pusiéron en ala, y levantando las voces todos juntos, comenzáron á cantar en su lengua lo que Sancho no pudo entender, sino fué una palabra, que Sancho no pudo en lor donde entendió, , por londe entendió, que era limosna la que en su canto pedian, y como el, segun dice Cide Hamete, cra caritativo ademas, sacó de sus alforjas medio pan y medio queso, de que venia proveido, y diósclo, diciéndoles por señas, que no tenia atra cosa que darles. Ellos lo recibiéron de muy buena gana dixéron: güelte güelte. No entiendo, respondió Sancho, que es lo que me pedis, buena gente. Entónces uno dellos saco un bolsa del seno, y mostrósela á Sanuno delos sacó una bols dal seno, y mostion dineros, $y$ é poniéndose el dedo pulgar en la garganta, y extendiendo la mano arriba les dió á entender, que no tenia ostugo de moneda, y picando al rucio rompió por cllos: y al pasar, habén
PARTEII. CAPYTULO IIV.

cion arremetió á ćl, cchíndole los brazos por la cintura, en voz alta y muy castcllana, dixo: válame Dios ̨que es lo que rco? es posible que tengo en mis brazos al mi caro amigo, al mi buen vecino Sancho Panza: Sí tengo sin duda, porque yo ni duermo, ni estoy ahora borracho. Admiróse Sancho de verse nombrar por su nombre, y de verse abrazar del extrangero peregrino, y despues de haberle estado mirando, sin hablar palabra, con mucha atencion, nunca pudo conocerle; pero viendo su suspension, el peregrino le dixo: como $\vdots y$ es posible Sancho Panza, her mano, que no conoces á tu vecino Ricote el Morisco, tendero de Tugar: Enrónces Sancho le miró con mas arencro de Lugar En cion, y comenzó á refigurarle , y finalmente le vino á conocer de todo punto, y sin apearse del jumento, le echo los brazos al cuello, y le dixo ¿quien diablos te habia de conocer, Ricote, en ese trage de moharracho que tracs? Dime quien te ha hecho Franchote $i y$ como tienes atrevimiento de volver á España, donde si te cogen y y conocen, tendrás harta mala ventura? Si tú no me discubres, Sancho, respondió el peregrino, seguro estoy, que en este trage no habrá nadie que me conozca, y apartéen este trage no habra nadie que me con camino á aquella alameda que allí parece, donmonos del camino á aquella alameda que all parece, donmerís con cllos, que son muy apacible gente : yo tendré lugar de contarc lo que me ha sucedido, despues que drc lugar de contarce lo que me ha sucedido, despues que me partí de nuestro Lugar, por obedecer el bando de Su Magestad, que con tanto rigor á los desdichados de mi nacion amenazaba, segun oiste. Hízolo así Sancho, $y$ habondo Ricote á los demas peregrinos, se apartáron á la alameda que se parecia , bien desviados del camino real. Arrojáron los bordones, quitáronse las mucetas, ó 
crclavinas, y quedáron en pelota, y todos ellos eran mozos, y muy gentileshombres, excepto Ricote, que ya era hombre entrado en años. Todos traian alforjas, $y$ todas, segun pareció, venian bien proveidas, aloménos de cosas incirarivas, y que llaman á la sed de dos leguas. Tendiéronse en el suclo, $\mathrm{y}$ haciendo manteles de las yerbas, pusiéron sobre cllas pan, sal, cucliillos, nueces, rajas de queso, huesos mondos de jamon, que si no se deJer chupados. Pusiéron asimismo un majar negro que dicen que se llama cabial $y$ es hecho de huevos de pescados, gran despertador de la colambre: no faltáron aceytunas, aunque secas, $y$ sin adobo alguno ; pero sabrosas, y entretenidas : pero lo mos campeó en cl campo de aquel banquete, fucron seis botas de vino, que cadia uno sacó la suya de su alforja : hasta el buen Ricote, que se habia transforma do de Morisco en Aleman, ó en Tudesco, sacó la suya, que en grandeza podia competir con las cinco. Coya que é groncr con grandísimo gusto y muy despacio, saboré́ndose con cada bocado, que le tomaban con Ia punta del cuchillo, y muy poquito de cada cosa, luce a punro todos á una levintíron los brazos, $y$ las botas en cl ayre, puestas las bocas en su boca, clavaclos los ojos en el ciclo, no parecia sino que ponian en él 1a puntería, y desta manera meneando las cabezas a un lajo $y$ atro, señales que acreditaban cl gusto que recebian, se estuviéron un buen espacio, trasegando en sus estómagos las entrañas de las vasijas. Todo lo miraba Sancho, y de ninguna cosa se dolia ; ántes por cumplir con el refran que él muy bien sabia, de quando á Roma fuéres haz como viéres, pidió á Ricote la bota, y tomó su puntería como los demas, y no con ménos gusto que ellos. Quatro veces diéron lugar las botas para ser empinadas, pero la quinta no fué posible, porque ya estaban mas enxutas, y secas que un esparto, cosa que puso mustia la alegría que hasta alli habian mostrado. De quando en quando juntaba alguno su mano derecha con la de Sancho, y decia : Español y Tudesqui tuto uno bon compaño, y Sancho respondia : bon compaño jura $\mathrm{Di}, \mathrm{y}$ disparaba con una risa, que le duraba un hora, sin acordarse entónces de nada de lo que le habia sucedido en su Gobierno, porque snbre el rato y tiempo quando se su Gobierno, porque sobre el rato y tiempo quando se dos. Finalmente el acabárseles el vino, fué principio de un sueño que dió á todos, quedándose dormidos sob un suchos Ricote y Sancho quedáron alerta, porque habian comido mas, y bebido ménos, y apartando Ricote á Sancho, se sentáron al pie de una haya dexando á los peregrinos sepultados en dulce une $y$ Ricote sin tropezar nada cn su lengua more sueños risca, en la pura castellana le dixo las siguientes razones:

Bien sabes, ó Sancho Panza, vecino y amigo mio, como el pregon y bando que Su Magestad mandó publicar contra los de mi nacion, puso terror y espanto en todos nosotros: aloménos en mí le puso, de suerte, que me parece que ántes del tiempo que se nos concedia, para que hiciésemos ausencia de España, ya tenia el rigor de la pena execurado en mi persona y en la de mis hijos. Ordené pues á mi parecer, como prudente (bien así como el que sabe que para tal tiempo le han de quitar la casa donde vive, $y$ se provee de otra donde mudarse) ordené, digo, de salir yo solo sin mi 
fanilia de mi pueblo, $y$ ir á buscar donde llevarla con comodidad, y sin la priesa con que los demas saliéron, porquie bien vi, y viéron todos nuestros ancianos, que pquellos pregones no eran solo amenazas, como algunos decian sino verdaderas leyes, que se habian de poner decian, sino verdaderas ley á tiempo, y forzábame á crecr esta verdad, saber yo los ruines y disparatados incos que los nuestros tenian, $y$ rales, que me parece que fué inspiracion divina la que movio a Su Magestad á poner cn efecto tan gallarja resolucion, no porque todos fuésemos culpados, que algunos habia christianos firmes y verdaderos; pero eran tan pocos, que no se podian oponer á los que no lo eran, y no era bien criar la sierpe en el seno, teniendo los enemigos dentro de casa. Finalmente con justa razon fuímos castigados con la pena del destierro, blanda y suave al parecer de algunos; pero al nuestro la mas terrible que se nos podia dar. Do quiera que estamos, lloramos por España, que en fin nacímos en ella, y es nuestra patria natural : en ninguna parte hallamos el acogimiento que nuestra desventura departe halla Bos acogimien de csperábamos ser recibidos, acogidos y regalados, allí es donde mas nos ofenden y maltratan. No hemos conocido el bien hasta gue le hemos perdido, y es el deseo ran grande que casi todos renemos de yolver á España, que los mas de aquellos, y son muchos, que saben la lengua como yo, se vuelven á ella, y dexan allá sus mugeres y sus hijos desamparados: tanto es el amor que la ienen, $y$ agora conozco y experimento lo que suele decirse, que es dulce el amor de la patria. Salí, como digo, de nuestro pueblo, entré en Francia , y aun-
PARTEII CAPITULO ITV.

que allí nos hacian buen acogimiento, quise verlo todo. qué á Iralia y llegué á Alemania, y allí me pareció Pasé á Tralia, y llegué a Alemania que se podia vivir con mas libertad, porque sus habitadores no miran en muchas delicadezas : cada uno vive como quiere, porque en la mayor parte della se vivc con librod de conciencia. Dexé tomada casa en un puccon liberad de concienciáme con estos peregrinos, que blo junto a Augusta, juntéme con estos peregrinos, que tienen por costumbre de venir á Espana muchos dellos cada año á visitar los Santuarios della, que los tiencn por sus Indias, y por certísima grangería y conocida gapor sus lndias, por cercina grangera yolo ninguno de nancia. Andanla casi toda, y no hay pueblo ninguno de donde no salgan comidos y bebidos, como suele decirse, y con un real, por lo ménos, en dineros, y al cabo de suige salen con mas de cien escudos de sobra, bo de su viage salen que trocados en oro, 0 ya en el hucco de los bordones, ó entre los remiendos de las esclavinas, o con la indus tria que ellos pueden, los sacan del Reyno, y los pasan

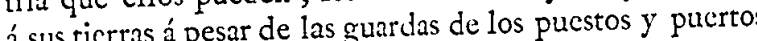
a sus ticrsas a pesar de las guardas intencion, Sancho, sadonde se resgistran. Ahora es mi intencion, Sancho, sacar el tesoro que dexé entcrrado, que por estar fuera del pueblo lo podrć hacer sin peligro, y escribir, ó pasar desde Valencia á mi hija y á mi muger, que sé que están en Argel, y dar traza como traerlas á algun puerto de FranAr esperarémos cia, y desde alli llevarlas a Alemania, donde esperalucion, lo que Dios quisiere hacer de nosotros: que en resolucion, Sancho, yo se cierto que la Ricota mija, y aunque Ricota mi muger, son católicas christanas, y aunque yo no lo soy tanto, todavia tengo mas de Christiano que de Moro, y ruego siempre á Dios me abra los ojos de entendimiento, y me dé á conocer como le tengo de ser vir: y lo que me tiene admirado es, no saber porque

$$
\text { Tom. Iv. }
$$


DON QUIXOTE DE IA MANCHA

se fué mi muger y mi hija ántes á Berbería que á Francia, adonde podia vivir como christiana. A lo que respondió Sancho : mira, Ricote, eso no debió estar en su mano, porque las llevó Juan Tiopieyo el hermano de tu muger, y como debe de ser fino Moro, fuese á lo mas bien parado, y séte decir otra cosa, que creo que vas en balde á buscar lo que dexaste encerrado, porque tuvímos nuevas que habian quitado á tu cunado y tu muger muchas perlas y mucho dinero en oro que llevaban por resgistrar. Bien puede ser eso, replicó Ricote ; pero yo sé, Sancho, que no tocáron á mi encierro, porque yo no les descubrí donde estaba, temeroso de algun desman : y así si tú , Sancho, quieres venir conmigo, y ayudarme á sacarlo y á encubrirlo, yo te daré docientos escudos, con que podrás remediar tus necesidades, que ya sabes que sé yo que las tienes muchas. Yo lo hiciera, respondió Sancho; pero no soy nada codicioso, que á serlo, un oficio dexć yo esta mañana de las manos, donde pudiera hacer las paredes de mi casa de oro , y comer ántes de seis meses en platos de plata: y así por esto como por parecerme haria traicion á mi Rey en dar favor á sus enemigos, no fuera contigo, si como me prometes docientos escudos, me dieras aquí de contado quatrocientos. ¿Y que oficio es el que has dexado, Sancho? preguntó Ricote. He dexado de ser Gobernador de una Insula, respondió Sancho, y tal, que á buena fe que no halle otra como ella á tres tirones a $Y$ donde está esa Insula? preguntó Ricote. : Adonde? respondió Sancho, dos leguas de aquí, y se llama la Insula Barataria. Calla, Sancho, dixo Ricote, que las Insulas están allá dentro de la mar, que no hay Insulas en la tierra firme. ¿Como

PARTE II. CAPITULO IIV.

no? replicó Sancho: dígote Ricote ${ }^{28}$ amigo, que esta manana me partí della, y ayer estuve en ella gobernando á mi placer, como un sagitario; pero con todo eso la he $\mathrm{mi}$ plase el de los Goberdexado, por parecerme ofcio peligroso de dos Gobernadores. :Y que has ganado en el Gobierno? pregunto Ricote. He ganado, respondió Sancho, el haber conocido, que no soy bueno para gobernar, sino es un hato de ga ganan en "los tale de ganado, y que las rquezas que se gascon en Gobiernos, son á costa de perder el descanso, y el sueño, $y$ aun el sustento, porque en las Insulas deben de no, y aun poco los Gobernadores, especialmente si tienen médicos que mircn por su salud. Yo no te entiendo, Sanmédicos que mire por su sáceme que todo lo que dicho, dixo Ricote ; pero parecme que todo lo que dices es disparate : que :quien te habia de dar a ti Insulas que gobernases? ¿Faltaban hombres en el mundo mas hábiles para Gobernadores que tú eres? Calla, Sancho, y biles para Gobernado si quieres venir conmigo, como te vuelve en ti, y mira si quiercs venir conmigo, comote he dicho, á ayudarme á sacar el tesoro que dexé escondido, que en verdad que es tanto, que se puede llamar tesoro, y te daré con que vivas, como te he dicho. $Y$ tesoro hicote, replicó Sancho, que no quiero: te he dicho, Ricote, no serís descubierto, y prosiconténtate que por mi no serás descubierto, y prosigue en buena hora tu camino, $y$ déxame seguir el mio, que yo sé que lo bien ganado se pierde, y lo malo, cllo y su dueño. No quiero porfiar, Sancho, dixo Ricote; pey su dueño. Nó quiero porfestro Lugar, quando se parro dime : hallastete en nuij y mi cuñado? Sí hallé , restió dél mi muger, mi hija y mi cuñado ? Sí hale, respondió Sancho, y séte decir, que salio tu hija tan hermosa, que saliéron á verla quantos habia en el pueblo, y todos decian, que era la mas bella criatura del mundo. Iba llorando, y abrazaba á todas sus amigas y conocidas, tom. rs. 
Y á quantos llegaban a verla, y a todos pedia la encomendasen á Dios, $y$ á nuestra Señora su madre: y esto con tanto sentimiento, que á mí me hizo llorar, que no suelo ser muy lloron: $y$ á fe que muchos tuviéron deseo de esconderla y salir a quitarsela en el camino ; pero el miedo de ir contra el mandado del Rey los detuvo: principalmente se mostró mas apasionado Don Pedro Gregorio, aquel mancebo mayorazgo rico que tú conoces, que dicen que la queria mucho, y despues que ella se partió, nunca mas él ha parecido en nuestro Lugar, $y$ todos pensámos que iba tras ella para robarla; pero hasta ahora no se ha sabido nada. Siempre tuve yo mala sospecha, dixo Ricote, de que ese caballero adamaba á mi hija ; pero fiado en el valor de mi Ricota, nunca me dió pesadumbre el saber que la queria bien, que ya habrás oido decir, Sancho, que las Moriscas, pocas, ó ninguna vez se mezcláron por amores con Christiano viejos , y mi hija, que á lo que yo creo atendia á scr mas christiana, que enamorada no se curaria de las solicitudes dese señor mayorazgo. Dios lo haga, replicó Sancho, que á entrámbos les estaria mal, y déxame partir de aquí, Ricote amigo, que quiero llegar csta noche adonde estí mi señor Don Quixore. Dios vaya contigo, Sancho hermano, que ya mis compañeros se rebullen, y tambien es hora que prosigamos nuestro camino, y luego se abrazáron los dos, y Sancho subió en su rucio, y Ricote se arrimó á su bordon, y se apartáron.

\section{CAPITULO LV.}

De cosas sucedidas á Sancho en el camino, y otras que no hay mas que ver.

El haberse detenido Sancho con Ricote, no le dió luEá que aquel dia llegase al castillo del Duque, puesto que llegó media legua dél, donde le tomó la noche alque llego media legua dero como era verano, no le dió go escura y cerrada; pcró como era del camino con in mucha pesadumbre : y asi se apartó del camino, con intencion de esperar la mañana, y quiso su corta y destencion de esper que buscando lugar donde mejor acomodarse, cayéron él y el rucio en una honda y escurísim sima, que entre unos edificios muy antiguos esrisima sima, que encomendó á Dios de todo taba, y al tiempo del caer se encomendo a Dios de todo corazon, pensando que no habia de parar hasta el profundo de los abismos: y no fué así, porque a poco mas de rres estados dió fondo cl rucio, y el se hallo encima dél, sin haber recibido lision, ni daño alguno. Tentose todo el cucrpo, y recogió el aliento, por ver si estaba sano, ó agujereado por alguna parte: $y$ viéndose bue ba sano, o agujereado por al salud, no se hartaba de dar no, entero, y catolico do salud, noced que le habia gracias a Dios nuestro Senor de la merced que le hab hecho, porque sin duda penso que estaba hecho mil pedazos. Tentó asimismo con las manos por las paredes de zos. Tcho as ver si seria posible salir della sin ayuda de la sima, por ver si serán nadie, pero todas las hallo rasas, yin asidero algne de lo que Sancho se congojo mucho, especialnente quando oyó que el rucio se quejaba tierna y dolorosamenquando oyo que ho ni se lamentaba de vicio, que á la te, y no crado. Ay, dixo entónces 
182

DON QUIXOTE DE LA MANCHA

Sancho Panza, y quan no pensados sucesos suelen suceder á cada paso á los que viven en este miserable mundo! - Quien divera que el que ayer se vió entronizado Gobernador de una Insula, mandando á sus sirvientes, y á sus vasallos, hoy se habia de ver sepultado en una sima, sin haber persona alguna que le remedie, ni criado, ni vasallo que acuda á su socorro? Aquí habrémos de perecer de hambre yo y mi jumento, si ya no nos morimos ántes, él de molido y quebrantado, y yo de pesaroso: aloménos no seré yo tan venturoso como lo fué mi señor Don Quixote de la Mancha, quando decendió y baxó á la cueva de aquel encantado Montesínos, donde halló quien le regalase mejor que en su casa, que no parece sino que se fué á mesa puesta, y á cama hecha. Allí vió él visiones hermosas y apacibles, y yo veré aquí, á lo que creo, sapos y culcbras. ¡ Desdichado de mí, y en que han parado mis locuras y fantasías! De aquí sacarán mis huesos, quando el Ciclo sea servido que me descubran, mondos, blancos y raidos, y los de mi buen rucio con ellos, por donde quizá se echará de ver quien somos, aloménos de los que tuvieren noticia que nunca Sancho Panza se apartó de su asno, ni su asno de Sancho Panza. Otra vez digo imiserables de nosotros! que no ha querido nuestra corta sucrte que muriésemos en nuestra patria y entre los nuestros, donde ya que no hallara remedio nuestra desgracia, no faltara quien della se dolicra, y en la hora última de nuestro pasamiento nos cerrara los ojos. iO compañero y amigo mio, que mal pago te he dado de tus buenos servicios! Perdóname, y pide á la fortuna, en el mejor modo que supieres, que nos saque deste miserable trabajo en que estamos puestos los dos, que yo
PARTEIT. CAPITUIOIV. ${ }^{2} 8_{3}$ prometo de ponerte una corona de laurel en la cabeza, que no parezcas sino un laureado poeta, y de darte los piennos doblados. Desta manera se lamentaba Sancho Panza, y su jumento le escuchaba sin responderle palabra alguna tal era el aprieto y angustia en que el pobre se hallaba. Finalmente, habiendo pasado toda aquella noche en miserables quejas y lamentaciones, vino el dia, con cuya claridad y resplandor vió Sancho que era imposible de toda imposibilidad salir de aquel pozo, sin ser ayudado, y comenzó á lamentarse y dar voces, por ver si alguno le oia; pero todas sus voces eran dadas en desierto, pues por todos aquellos contornos no habia persona que pudiese escucharle, y entónces se acabó de dar por muerro. Estaba el rucio boca arriba, y Sancho Panza le acomodó de modo que le puso en pie, que apénas se podia tener, y sacando de las alforjas, que tambien habian corrido la mesma fortuna de la caida, un pedazo de pan lo dió á su jumento, que no le supo mal, y díxole Sancho, como si lo entendiera: todos los duclos con pan son buenos. En esto descubrió á un lado de la sima un agujero, capaz de caber por él una persona, si se agoagujero , capar de cabó ́l Sancho Panza y agazapínviaba y encogia. Acudió a el Sancho Panza, y agazapandose se entró por él y vió que por de dentro era espacioso y largo, y púdolo ver porque por lo que se podis llamar techo entraba un rayo de sol, que lo descudia llamar trió otra concavidad espaciosa, viendo lo qual, volvió á salir adonde estaba el jumento, $y$ con una piedra comenzó desmoronar la tierra del agujero, de modo que en poco espacio hizo lugar donde con facilidad pudiese entrar el asno, como lo hizo, y cogiéndole del cabestro 
184 DON QUIXOTE DE LA MANCHA

comenzó á caminar por aquella gruta adelante, por ver si hallaba alguna salida por otra parte: á veces iba á escúras, $y$ á veces sin luz; pero ninguna vez sin miedo. ¡Válame Dios todo poderoso! decia entre sí: esta que para mí es desventura, mejor fuera para aventura de mi amo Don Quixote. Él sí que tuvicra estas profundidades, mazmorras por jardines floridos y por Palacios de $\mathrm{Ga}$ liana, y esperara salir desta escuridad y estrecheza á algun florido prado ; pero yo sin ventura, falto de consejo, y menoscabado de ánimo, á cada paso pienso que debaxo de los pies de improviso se ha de abrir otra sima mas profunda que la otra, que acabe de tragarme. Bien vengas mal, si vienes solo. Desta mancra, y con estos pensamientos le pareció que habria caminado poco mas de media legua, al cabo de la qual descubrió una confusa claridad, que pareció ser ya de dia , y que por alguna parte entraba, que daba indicio de tener fin abierto aquel, para él, camino de la otra vida. Aquí le dexa Cide Hamete Benengeli, y vuelve á tratar de Don Quixore, que alborozado y contento esperaba el plazo de la batalla que habia de hacer con el robador de la honra de la hija de Doña Rodriguez, á quien pensaba enderezar el tuerto y desaguisado, que malamente le tenian fecho. Silcedió pues, que saliéndose una mañana á imponerse y ensayarse en lo que habia de hacer en el trance en que otro dia pensaba verse, dando un repelon, ó arremetida á Rocinante, llegó á poner los pies tan junto á una cueva, que á no tirarle fuertemente las riendas, fuera imposible no cacr en ella. En fin le detuvo, y no cayó y llegándose algo mas cerca, sin apearse miró aquella hondura, y estándola mirando oyó grandes voces dentro,
PARTEII. CAPITULOLV.

$y$ escuchando atentamente, pudo percebir $y$ entender que el que las daba decia: ha de arriba : hay algun christiano que me escuche? ;ó algun caballero caritativo que se duela de un pecador cnterrado en vida? ¿ de un desdichado desgobernado Gobernador? Parecióle á Don Quixote, que oia la voz de Sancho Panza, de que quedó suspenso y asombrado, y levantando la voz todo lo que pudo, dixo: ¿ quien está allá abaxo? ¿quien se queja? ¿Quien puede estar aquí, ó quien sc ha de quejar ? respondiéron, sino el asendereado de Sancho Panza, Gobernador por sus pecados y por su mala andanza de la Ínsula Barataria, escudero que fué del famoso caballero Don Quixore de la Mancha. Oyendo lo qual Don Quixote, se le dobló la admiracion, $y$ se le acrecento el pasmo, viniéndosele al pensamiento que Sancho Panza debia de ser muerto, y que estaba allí penando su alma, y llevado desta imaginacion, dixo: conjurote por todo aquello que fuedo conjurarte como católico christiano, que me digas quien eres, $y$ si eres alma cn pena, dime que quieres que haga por ti, que pues es mi profesion favorecer y acorrer á los necesitados deste mundo, tambien lo seré para acorrer y ayudar á los menestcrosos del otro mundo, que no pueden ayudarse por sí propios. Desa manera, respondiéron, vuesa merced que me habla, debe de scr mi señor Don Quixote de la Mancha, y aun en el órgano de la voz no es otro sin duda. Don Quixote soy, replicó Don Quixote, el que profeso socorrer $y$ ayudar en sus necesidades á los vivos y á los muertos: por eso dime quien eres, que me ticnes atónito, porque si eres mi escudero Sanque me tiches ato hito, porque como no te hayan llevado los diablos, y por la miscricordia de Dios estés en el zom. w. 
purgatorio, sufragios tiene nuestra Santa Madre la Iglesia Católica Romana bastantes á sacarte de las penas en que estás, y yo que lo solicitaré con ella por mi parte con quanto mi hacienda alcanzare : por eso acaba de declararte, y dime quien eres. Voto á tal, respondiéron, y por el nacimiento de quien vuesa merced quisiere, juro, senor Don Quixore de la Mancha, que yo soy su escudero Sancho Panza, y que nunca me he mucrto en todos los dias de mi vida; sino que habiendo dexado mi Gobierno por cosas y causas, que es menester mas espacio para decirlas, anoche caí en esta sima, donde yago, y el rucio conmigo, que no me dexará mentir, pues por mas señas está aquí conmigo. $Y$ hay mas, que no parece sino que el jumento entendió lo que Sancho dixo, porque al momento comenzó á rebuznar tan recio, que toda la cucva retumbaba. Famoso testigo, dixo Don Quixote, el rebuzno conozco, como si le pariera, y tu voz oigo, Sancho mio, espérame, iré al castillo del Duque, que está aquí cerca, y traeré quien te saque desta sima, donde tus pecados te deben de haber puesto. Vaya ruesa merced, dixo Sancho, y ruelva presto por un solo Dios, que ya no lo puedo llevar el estar aquí sepultado en vida, y me estoy muriendo de miedo. Dexóle Don Quixote, y fué al castillo á contar á los Duques el suceso de Sancho Panza, de que no poco se maravilláron, aunque bien entendiéron que debia de haber caido por la correspondencia de aquella gruta, que de tiempos inmemoriales estaba allí hecha; pero no podian pensar como habia dexado el Gobierno, sin tener ellos aviso de su venida. Finalmente, como dicen, lleváron sogas, y maromas, y á costa de mucha gente, y de mucho trabajo sa- cáron al rucio, y á Sancho Panza de aquellas tinieblas á la luz del sol. Vióle un estudiante, y dixo : desta manera habian de salir de sus Gobiernos todos los malos Gobernadores, como sale este pecador del profundo del abismo, muerto de hambre, descolorido y sin blanca, á lo que yo creo. Oyólo Sancho, y dixo : ocho dias, ó diez ha, hermano murmurador, que entré á gobernar la Insula que me diéron, en los quales no me vi harto de pan siquiera un hora: en ellos me han perseguido médicos, y enemigos me han brumado los huesos, ni he tenido lugar de hacer cohechos, ni de cobrar derechos: $y$ siendo esto así, como lo es, no merecia yo, á mi parecer, salir de esta manera; pero el hombre pone, y Dios dispone, y Dios sabe lo mejor, y lo que le está bien á cada uno, y qual el tiempo tal el tiento, y nadie diga desta agua no beberé, que adonde se piensa que hay tocinos no hay estacas : y Dios me entiende, y basta, y no digo mas, aunque pudiera. No te enojes, Sancho, ni recibas pesadumbre de lo que oyeres, que será nunca acabar: ven tú con segura conciencia, y digan lo que dixeren, $y$ es querer atar las lenguas de los maldicientes, lo mesmo que querer poner puertas al campo. Si el Gobernador sale rico de su Gobierno, dicen dél, que ha sido un ladron: y si sale pobre, que ha sido un para poco, y un mentecato. Á buen seguro, respondió Sancho, que por esta vez ántes me han de tener por tonto, que por ladron. En estas pláticas llegáron rodeados de muchachos, y de orra mucha gente al castillo, adonde en unos corredores estaban ya el Duque, y la Duquesa esperando á Don Quixote, y á Sancho, el qual no quiso subir á ver al Duque, sin que primero no hubiese acomodado ToM. Iv. 
I 88

DON QUIXOTE DE IA MANCHA

al rucio en la caballeriza, porque decia, que habia pasado muy mala noche en la posada, y luego subió á ver á sus señores, ante los quales puesto de rodillas, dixo: yo, señores, porque lo quiso así Vuestra Grandeza, sin ningun merecimiento mio, fuí á gobernar vuestra Insula Barataria, en la qual entré desnudo, y desnudo me hallo, ni pierdo, ni gano. Si he gobernado bien, ó mal, testigos he tenido delante, que dirán lo que quisicren. He declarado dudas, sentenciado pleytos, y siempre muerto de hambre, por haberlo querido así el Doctor Pedro Recio, natural de Tirteafuera, médico insulano y gobernadoresco. Acometiéronnos enemigos de noche, $y$ habiéndonos puesto en grande apricto, dicen los de la Insula que saliéron libres y con vitoria por el valor de mi brazo: que tal salud les dé Dios, como ellos dicen verdad. En resolucion, en este tiempo yo he tanteado las cargas que trae consigo, $y$ las obligaciones el robernar, $y$ he hallado por mi cuenta, que no las podrón llevar mis hombros, ni son peso de mis costillas flechas de mi aljaba: y así ántes que diese conmigo al traves el Gobierno, he querido yo dar con el Gobierno al traves, y ayer de mañana dexé la Insula como la hallé, con las mismas calles, casas $y$ tejados que tenia quando entré en ella. No he pedido prestado á nadie, ni metídome en grangerías : $y$ aunque pensaba hacer algunas ordenanzas provechosas, no hice ninguna, temeroso que no se habian de guardar, que es lo mesmo hacerlas, que no hacerlas. Salí, como digo, de la Insula, sin otro acompañamiento que el de mi rucio : caí en una sima, víneme por ella adelante, hasta que esta mañana con la luz del sol vi la salida; pero no tan fácil, que á no deparar-
PARIEII. CAPÍTUIOLV.

me el Cielo" á mi scíor Don Quixote, allí me quedara hasta la fin del mundo. Así que, mis señores Duque y Duquesa, aquí cstá vuestro Gobernador Sancho lanza, que ha grangeado en solos diez dias que ha tenido el Gobierno, conocer" que no se le ha de dar nada por ser Gobernador, no que de una Ínsula, sino de todo el mundo, y con este presupuesto, besando á vuesas mercecies los pies, imitando al juego de los muchachos, que dicen: salta tú y dámela tú, doy un salto del Gobierno, y me paso al servicio de mi señor Don Quixote, que en fin en él, aunque como el pan con sobresalto, hártome aloménos, y para mí, como yo esté harto, eso me hace que sea de zanahorias, que de perdices. Con esto dió fin á su larga plática Sancho, temiendo siempre Don Quixote, que habia de decir en ella millares de disparates, y quando le vió acabar con tan pocos, dió en su corazon gracias al Ciclo, y el Duque abrazó á Sancho, y le dixo que le pesaba en el alma de que hubiese dexado tan presto el Gobierno; pero que él haria de suerte, que se le diese en su Estado otro oficio de ménos carga, y de mas provecho. Abrazóle la Duquesa asimismo y mandó que le regalasen, porque daba señales de venir mal molido y peor parado.

\section{CAPITULO LVI.}

De la descomunal y nunca vista batalla que pasó entre Don Quixote de la Mancha, y el lacayo Tosilos en la defensa de la hija de la dueña Doña Rodriguez.

No quedáron arrepentidos los Duques de la burla hecha á Sancho Panza del Gobierno que ie diéron, y mas, 
190

DON QUIXOTE DE IA MANCHA

que aquel mismo dia vino su mayordomo, y les contó punto por punto casi todas las palabras y acciones que Sancho habia dicho $y$ hecho en aquellos dias : y finalmente les encareció el asalto de la Insula, y el miedo de Sancho, les encareció el asalto de la Insula gusto recibiéron. Despues y su salida, de que desto cuenta la historia, que se llegó el dia de la batalla aplazada, y habiendo el Duque una y muy muchas veces atverido á su lacayo Tosílos como se habia de avenir rirle, ordenó, que se quitasen los hicrros á las lanzas, diciendo á Don Quixote, que no permitia la christiandad, de que él se preciaba, que aquella batalla fuese con danto riesgo y peligro de las vidas, $y$ que se contentase con que le daba campo franco en su tierra, puesto que iba contra el decreto del santo Concilio, que prohibe los tales desafios, y no quisiese llevar por todo rigor aquel trance tan fuerte. Don Quixote dixo, que $\mathrm{Su}$ Excelencia dispusiese las cosas de aquel negocio como Excelencia dispusiese las cél le obedeceria en todo. Llegado pues el temeroso dia, y habiendo mandado el Duque, que delante de la plaza del castillo se hiciese un esque pacioso cadahalso, donde estuvicen los jueces del campo, y las dueñas, madre y hija demandantes, habia acudido de todos los Lugares y Aldeas circunvecinas in finita gente á ver la novedad de aquella batalla, que nunce otra al no habian visto ni oido decir en aquelia primero que entró en el campo, y estacada fué el Maes tro de las ceremonias, que tanteó el campo, y le paseó todo, porque en él no hubiese algun engaño, ni otra cosa encubierta, donde se tropezase y cayese : luego en-
PARTEII. CAPÍTULO LVI.

tráron las dueñas, y se sentáron en sus asientos, cubicrtas con los mantos hasta los ojos, y aun hasta los pechos, con muestras de no pequeño sentimiento, presente Don Quixote en la estacada. De allí á poco acompañado de muchas trompetas, asomó por una parte de la plaza, sobre un poderoso caballo, hundiéndola toda, cl grande lacayo Tosílos, calada la visera, y todo encambronado con unas fucrtes y lucientes armas. EI caballo mostraba ser frison, ancho, $y$ de color tordillo: de cada mano $y$ pie le pendia una arroba de lana. Venia el valcroso combatiente bien informado del Duque su señor, de como se habia de portar con el valeroso Don Quixote de la Mancha, advertido que en ninguna manera le matase, sino que procurase huir el primer encuentro, por excusar el peligro de su muerte, que estaba cierto, si de lleno en lleno le encontrase. Paseó la plaza, y llegando donde las ducñas estaban, se puso algun tanto á mirar á la que por esposo le pedia : llamó el Macse de Campo á Don Quixote, que ya se habia presentado en la plaza , y junto con Tosílos habló á las ducñas, preguntándoles si conscntian que rolviese por su derecho Don Quixote de la Mancha. Ellas dixéron que si, y que todo lo que en aquel caso hiciese, lo daban por bien hecho, por firme y por valedero. Ya en este tiempo estaban el Duque y la Duquesa puestos en una galeria, que cais sobre la estacada, toda la qual estaba coronada de infinita gente, que esperaba ver el riguroso trance nunca visto. Fué condicion de los combatientes, que si Don Quixote vencia, su contrario se habia de casar con la hija de Dona Rodriguez, y si el fuese vencido quedaba libre su contendor de la palabra que se le pedia sin 
192

DON QUTXOTE DE IA MANCHA

dar otra satisfacion alguna. Partióles el Maestro de las ceel sol, y puso á los dos cada uno en el puesremonias cl sol, y puso a los dón cada uno en el puesto donde habian de estar. Sonaron los atambores, lle nó el ayre el son de las trompetas, temblaba debaxo de los pics la tierra: estaban suspensos los corazones de la los pics la terra: esmiendo unos, $y$ espcrando otros $\mathrm{cl}$ mirante turba , tcniendo unos, y espontmente Don bueno, ó el mal suceso de aquel caso. Finalmente Don Quixore, encomendíndose de todo su corazon a Dios nuestro Señor, y á la Señora Dulcinea del Toboso, esnuestro Senor ge diese señal precisa de la arretaba aguardando que le de diferentes pensa metida ; empero nucstro lacayo tenia difercntes pensa mientos: no pensaba él sino en lo que agora dire. Pa rece ser, que quando estuvo mirando á su enemiga, le rcce ser , que quando ${ }^{33}$ muger, que habia visto en toda parecio la mas hernos su vida, y el niño ceguezuelo, á quien suelen llamar de ordinario amor por esas calles, no quiso perder la oca sion que se le ofreció de triunfar de una alma lacayuna, yon trofeos, y así llegándose á y ponerla en la lista de sus le viese, le embasó al poel bonitamente sin que nadie le vise, le cmba izquierdo, bre lacayo una flecha de dos varas por el lado izquierdo, y le pasó el corazon de parte á parte: y púdolo hacer bien al seruro, porque el amor es invisible, y cntra y bien al sue nadie le pida cuenta de sus hechos. Digo pues, que quando diéron la señal de la arremetida estaba nuestro lacayo transportado, pensando en la hermosura de la que ya habia hecho señora de su en la hermosura de la qué ya de la trompeta, como hizo Don Quixote, que apénas la hubo oido, quando arremetió, y á todo el correr que permitia Rocinante, partió contra su enemigo, y viéndole partir su buen escudero
PARTEII. CAPITULO IVY.

y flor de los andantes caballeros: Dios te dé la viroria, pues llevas la razon de tu parte. Y aunque Tosílos vió venir contra sí á Don Quixote, no se movió un paso de su pucsto ; ántes con grandes roces llamó al Macse de Campo, cl qual venido á ver lo que queria, le dixo: senor ¿csta batalla no se hace porque yo me case, ó no me case con aquella señora? Así es, le fué respondido. Pues yo, dixo el lacayo, soy temeroso de mi conciencia, $y$ pondríala en gran cargo, si pasase adclante en esta batapondriala en gran cargo, si digo, que yo me doy por vencido, y que quiero casarme luego con aquella scñora. Quedó admirado cl Maese de Campo de las razones de Tosílos, y como era uno de los sabidores de la máquina de aquel caso, no le supo responder palabra. Detúvose Don Quixote en la mitad de su carrera, viendo que su enemigo no le acometia. El Duque no sabia la ocasion por que no se pasala adelante en la batalla ; pero el Maese de Campo le fué á declarar lo que Tosílos decia, de lo que quedó suspenso y colérico en extremo. En tanto que esto pasaba, Tosílos se llegó adonde Doña Rodriguez estaba, y dixo á.grandes voces: yo, señora, quiero casarme con vucstra hija, y no quiero alcanzar por pleytos, ni contiendas lo que puedo alcanzar por paz, y sin peligro de la muerte. Oyó esto el valeroso Don Quixote, y dixo : pues esto así es, yo quedo libre y suelto de mi promesa: pues Dios nuestro Scñor se la dio , San Pedro se la bendiga. El Duque habia baxado á la plaza del castillo, y llegándose á Tosílos, le dixo: ies verdad, caballero, que os dais por vencido, y que intigado de vuestra temerosa conciencia os quereis casar con esta doncella? Sí señor, respondió Tosílos. El hace rom. av. 
I 94

DON QUTXOTE DE LA MANCHA

muy bien, dixo á esta sazon Sancho Panza, porque lo que has de dar al mur, dalo al gato, y sacarte ha de cuique Íase Tosílos desenlazando la celada, y rogaba que apriesa le ayudasen, porque le iban faltando los espíritus del aliento, y no podia verse encerrado tanto tiempo en la estrecheza de aquel aposento. Quitáronsel po en la estech decubierto y patente su rostro del la cayo. Viendo lo qual Doña Rodriguez y su hija, dando grandes voces, dixéron : este es engaño, engaño es este á Tosílos el lacayo del Duque mi señor nos han puesto en lugar de mi verdadero esposo: justicia de Dios y del Rey de tanta malicia , por no decir bellaquería. No vos acuiteis, señoras, dixo Don Quixote, que ni esta es malicia, ni es bellaquería, y si la es, no ha sido la causa el Duque sino los malos encantadores que me persiguen, los quales invidiosos de que yo alcanzase la gloria deste vencimiento, han convertido el rostro de vuestro esposo en el de este que decis que es lacayo del Duque: tomad mi consejo, y á pesar de la malicia de mis enemigos casaos con él, que sin duda es el mismo que vos deseais alcanzar por esposo. El Duque que esto oyó, estuvo por romper en risa toda su cólcra, y dixo: son tan exrraordinarias las cosas que suceden al señor Don Quixote, que estoy por creer, que este mi lacayo no lo es; pero usemos deste ardid y maña : dilatemos el casamiento quince dias, si quieren, y tengamos cncerrado á este personage, que nos tiene dudosos, en los quales podria ser que volviese á su prístina figura, que no ha de durar tanto el rancor que los encantadores tienen al señor Don Quixote, y mas yéndoles tan poco en usar estos embelecos y transformaciones. ¡Ó señor! dixo
PARTE CAPITULO LVI.

Sancho, que ya tienen estos malundrines por uso y costumbre de mudar las cosas de unas en otras, que tocan á mi amo. Un caballero que venció los dias pasados, llamado cl de los Espcjos, le volviéron en la figura del Bachiller Sanson Carrasco, natural de nucstro pueblo y grande amiro nuestro, y á mi Señora Dulcinea del Toboso la han vuclto en una rústica labradora, $\mathrm{y}$ así imagino que este lacayo ha de morir y vivir lacayo todos los dias de su vida. A lo que dixo la hija de Rodriguez: séase quien fuere este que me pide por esposa, que yo se lo agradezco, que mas quiero ser muger legítima de un lacayo, que no amiga y burlada de un caballcro, puesto que el que á mí me burló no lo es. En resolucion, todos estos cucntos y sucesos paráron en que Tosílos se recogiese, hasta ver que paraba su transformacion. Aclamáron todos la ver en que paraba su transformacion. Aclamaron todos la lancólicos de ver que no se habian hecho pedazos ios tan espcrados combatientes, bien así como los mochachos quedan tristes quando no sale cl ahorcado que esperan, porque le ha perdonado, ó la parte, ó la justicia. Fuése la gente, volviéronse el Duque y Don Quixote al castillo, encerráron á Tosílos, quedáron Doña Rodriguez y su hija contentísimas de ver que por una via, ó por otra aquel caso habia de parar en casamiento, y Tosílos no esperaba ménos.

\section{CAPITTULO LVII.}

Oue trata de como Don Quixote se despidió del Duque, $y$ de lo que lo sucedió con la discreta y desenvulelta altisidora, doncella de la Duquesa.

Ya le pareció á Don Quixote, que era bien salir de

Y a le pareció a Don Quixote, que cra bi 
PARTEII. CAPIIUIO IVII.

tanta ociosidad como la que en aquel castillo tenia, que se imaginaba ser grande la falta que su persona hacia en dexarse estar cncerrado y perezoso entre los infinitos regalos y deleytes, que como á caballero andante aquellos señores le hacian, y pareciale que habia de dar cuenta estrecha al Ciclo de aquella ociosidad y encerramiento, y así pidió un dia licencia á los Duques para parrirse. Diéronsela con muestras de que en gran manera les pesaba de que los dexase. Dió la Duquesa las cartas de su muger á Sancho Panza, el qual lloró con ellas, y dixo ¿quien pensara, que esperanzas tan grandes como las que en el pecho de mi nuger Teresa Panza engendráron las nuevas de mi Gobierno, habian de parar en volverme yo agora á las arrastradas aventuras de mi amo Don Quixote de la Mancha! Con todo esto me contento de ver que mi Teresa correspondio a ser quien es, enviando las bellotas á la Duguesa, que á no habérsclas enviado, quedando yo pesaroso, se mostrara clla desagradecida. Lo que me consucla es, que á esta dádiva no se le puede dar nombre de cohecho, porque ya tenia yo el Gobierno quando ella las envió, y está puesto en razon, que los que reciben algun bencficio, aunque sea con niñerías se nuestren agradecidos. En efecto , yo entré desnudo en el Gobierno, y salgo desnudo de él, y así podré decir con segura conciencia , que no es poco: desnudo nací, desnudo me hallo, ni pierdo, ni gano. Esto pasaba entre sí Sancho el dia de la partida y saliendo Don Quixote, habiéndose despedido la noche úntes de los Duques, una mañana sc presentó armado en la plaza del castillo. Mirábanle de los corredores toda la gente del castillo, y asimismo los Duques saliéron á ver- 1c. Estaba Sancho sobre su rucio con sus alforjas, malcta y respuesto contentísimo, porque el mayordomo del Duque, el que fué la Trifaldi, le habia dado un bolsico con docientos escudos de oro, para suplir los menesteres del camino, y esto aun no lo sabia Don Quixote. Estando como queda dicho, mirándole todos, á deshora entre las otras dueñas y doncellas de la Duquesa que le miraban, alzó la voz la desenvuclta y discreta Altisidora, y en son lastimero dixo :

Escucha, mal caballero,

deten an poco las riendas,

no fatigues las hijadas

de tu mal regida bestion.

Mira falso que no hulyes

te alguna serpionte fiera,

sino de una corderilla,

quic está muy líxos de oveja.

Tü has burlado, monstruo horrendo,

la mats hermosa doncella,

que Diana vió en sus montes,

gue Vínues miró en sas selvas.

Cruel Vireno, fusitivo Encias,

Barrabas te acompañe, allá te avengas.

Tú llevas ; llevar impio!

en las garras de tus cerras

las entrañas de uni humilde,

como enamorada tierna.

Ilevaste tres tocadores,

$y$ unas ligas de unas piernas, 
DON QUIXOTE DE LA MANCHA que al mármol puro se igualan en lisas, blancas y negras. Llévaste dos mil suspiros, que á ser de fuego, pudieran querasar á dos mil Troyas, si dos mil Troyas hubiera. Cruel Vireno, fugitivo Encias, Barrabas te acompañe, allá te avengas.

De ese Sancho tu escudero, las entrañas sean tan tercas y tan duras, que no salga de su encanto Dulcinea.

De la culpa que tú tienes, lleve la triste la pena: que justos por pecadores tal vez pagan en mi tierra.

Tus mas finas aventuras

en desventuras se vuelvan,

en sucrios tus pasatiempos,

en olvidos tus firmezas.

Cruel Vireno, fugitivo Enéas,

Barrabas te acompañe, allá te avengas.

Seas tenido por falso,

desde Scuilla á Marchena,

desde Granada hasta Loja

de Lóndres á Ingalaterra.

Si jugares al reynado,

los cientos, ó la primera,

los Reyes huyan de ti,
PARTEII. CAPIIULO IVII.

ases, 21 i sietes 120 veas.

Si te cortares los callos,

sangre las heridas viertan,

y quédente los raigones,

site sacares las muclas.

Cruel Vireno, fugitivo Enias,

Barrabas te acompañe, allá te avengas.

En tanto que de la suerte que se ha dicho se quejaba la lastimada Alrisidora, la estuvo mirando Don Quixote , y sin responderla palabra, volviendo el rostro Sancho, le dixo: por el siglo de tus pasados, Sancho mio, te conjuro que me digas una verdad : dime ;llevas por ventura los tres tocadores, y las ligas que esta enapor ventura los tres tocadores, y las liga que respondió : los tres tocadores sí llevo ; pero las ligas, como por los cerros de Úbcda Qucdó la Duquesa admirada de la descnvoltura de Altisidora, que aunque la tenia por atrevida, graciosa y desenvuelta, no en grado que se atreviera í semejantes desenvolturas: y como no estaba ad verida desta burla, creció mas su admiracion. El Duque quiso reforzar el donayre, y dixo: no me parece bien, señor caballero, que habiendo recebido en este mi castillo el buen acogimiento que en él se os ha hecho, os hayais atrevido á llevaros tres tocadores por lo ménos si por lo mas las ligas de mi doncella : indicios nos de mal pecho, y muestras que no corresponden á vuestra fama: volvedle las ligas, si no yo os desafio á mortal batalla sin tener temor, que malandrines encantadores me vuclua ni muden el rostro, como han hedores món 
en batalla. No quicra Dios, respondió Don Quixote, que yo dentra ilustrísima persoyo desenvanc micebico: los tocajores na, de quicn tantas mercedes he recebito: los tocalores volveré, porque dice Sancho que los tiene : las ligas cs imposible, porque ni yo las he recebido, ni ćl tampoco, y sirar escondrijos, y si esta vue buen seguro que las halle. Yo, sento Di vida janto sido ladron, ni lo pienso ser en toda mi vida, como Dios no me dexe de su mano. Esta doncclia, liabla , como ella dice, como enamorada, de lo que yo no le tengo culpa y ás no tengo de que pedirle perdon, ni á cllo culpa , y asi no tengo de que pedirle plico me tenga ni á Vuestra Excelencia, á quicn suplico me tenga ca mejor opinion, y me dé de nuevo licencia para seguir nu camino. Déosle Dios tan bueno, dixo la Duquesa, scínor Don Quixote que siempre oigamos bucnas nucvas de vuestras fechurías, $y$ andad con Dios, que miéntras mas os deteneis mas aumentais el fucgo en los pechos de las doncellas que os miran, y á la mia yo la castigaré de modo que de aquí adelanre no se desmande con la vista, ni con las palabras. Una no mas quiero que me escuches, ó valeroso Don Quixote, dixo entónces Altisidora, y es, que te pido perdon del latrocinio de las ligas, porque en Dios, $y$ en mi ánima que las tengo pucstas, $y$ he coido caba. No lo dixe yo, dixo Sancho, bonico soy yo para encubrir hurtos, pues á quererlos hacer, de palcta me habia venido la ocasion en mi Gobierno. Abaxó la cabeza Don Quixote, y hizo reverencia á los Duques, y á todos los circunstantes, y volviendo las riendas á Rocinante, siguiéndole Sancho sobre el rucio, se salió del castillo, cnderezando su camino á Zaragoza.

\section{CAPÍTULO LVIII.}

Que trata de como menudeáron sobre Don Ouixote aventumas tantas, que no se daban vagar

$$
\text { anas á otras. }
$$

Quando Don Quixote se vió en la campaña rasa, libre y desembarazado de los requicbros de Altisidora, lc pareció que estaba en su centro, y que los espíritus se pareció que estaba en su centro, y que los espiritus se le renovaban para proseguir de nuevo el asunto de sus caballerías, y volviéndose á Sancho, le dixo: la libertad, Sancho, es uno de los mas preciosos dones que a los hombres diéron los Cielos: con ella no pueden igualarse los tesoros que encierra la tierra, ni el mar encubre: por la libertad, así como por la honra, se puede y debe aventurar la vida, y por el contrario, el cautiverio el mayor mal que puede venir á los hombres. Digo esto, Sancho, porque bien has visto el regalo, la abundancia que en este castillo que dexámos, hemos tenido: pues en metad de aquellos banquetes sazonados, $y$ de ba metido entre las estrechezas de la hambre, porque no lo gozaba con la libertad que lo gozara si fueran mios: que las obligaciones de las recompensas de los beneficios qu man on dexan camy merceles recebias, son ara pear el ánimo libre. Venturoso aquel a quien el Ciclo dió un pedazo de pan, sin que le quede obligacion de agradecerlo á otro que al mismo Ciclo. Con todo eso, dixo Aecerlo atro que al mismo me ha dicho, no es bien Sancho, que vucsa merced me nuestra parte docicnque se quede sin agradecimienco de nuelta me dio tos escudos de oro, que en una bolsiila me Ton. Ir 
PARIEII. CAPITULO LVIII. 203

yordomo del Duque, que como píctima y confortativo la llevo puesta sobrc al corazon, pura lo que se ofrecic re, que no siempre hemos de hallar castillos donde nos regalen, que tal vez toparémos con algunas ventas donde nos apalécn. En estos y otros razonamientos iban los andantes caballero y escudero, quando viéron, habiencio andado poco mas de una legua, que encima de la yerba de un pradillo verde, encima de sus capas estaban comicndo hasta una docena de hombres, vestidos de labradores. Junto á sí tenian unas como sábanas blancas, con que cubrian alguna cosa que debaxo cstaba: estaban empinadas y tendidas, y de trecho á trecho puestas. Llegó Don Quixote á los que comian, y saludándolos primero cortesmente, les preguntó, que que era lo que aquellos lienzos cubrian. Uno dellos le respondió : señor, debaxo destos lienzos están unas imágines de relieve y entalladura, que han de servir en un retablo, que hacemos en nuestra aldea: llevámoslas cubiertas, porque no se desfloren, $y$ en hombros, porque no se quiebren. Si sois servisos, respondió Don Quixote, holgaria de vcrlas, pucs imúgines que con tanto recato se llevan, sin duda deben de ser buenas. $Y$ como si lo son, dixo otro, si no dígalo lo que cuestan, que en verdad que no hay ninguna que no esté en mas de cincuenta ducados, y porque vea vuesa merced esta verdad, espere vuesa merced, y verla ha por vista de ojos: y levantándose dexó de comer, y fué á quitar la cubierta de la primera imágen, que mostró ser la de Sun Jorge puesto á caballo con una scrpiente enroscada á los pies, y la lanza atravesada por la boca , con la fiereza que suele pintarsc. Toda la imágen parccia una ascua de oro, como suele decirse. Viéndo- la Don Quixote, dixo: este caballero fue uno de los mejores andantes que turo la milicia divina : llamóse Don San Jorge, y fuć adcmas defendedor de cioncellas. Viamos esta otra. Descubrióla el hombre, y parcció ser la de San Martin, pucsto á caballo, que partia la capa con el pobre $y$ án la hubo visto Don Quixote, quando pobre, y apenas ta hubo visto Don Quixore, quando ntureros christianos, y creo que fué mas liberal, que valiente, como lo puedes echar de ver, Sancho, en que está partiendo la capa con el pobre, y le da la mitad, $y$ sin duda debia de ser entónces invierno, que si no el se la diera toda, segun era de caritativo. No debió de ser eso, dixo Sancho, sino que se debió de atener al refran que dicen: que parz dar y tener, seso es mencster. Riósc Don Quique para dis y teme quitasen orro lienzo debavo del qual xote, $y$ pidio que quitasen otro lienzo, dcbaxo del qual se descubrió la imágen del Patron de las Espanas a caballo, la espada ensangrentada atropellando Moros, y pisando colezas, y en viéndola dixo Don Quixote : este pisando cabezas, y en las esquadras de Christo este se llama Don San Diego Matamoros, uno de los mas valientes Santos, y caballeros que turo el mundo, y tiene agora el ciclo. Luego descubriéron otro lienzo, y pareció que encubria la caida de San Pablo del caballo abarecio que encubria la caida de Sin Piblo del cabalo abaxo, con todas las circunstancias que en el retablo de su conversion suelen pintarse. Quando le vido tan al vivo, que dixeran que Christo le hablaba, $y$ Pablo respondia: que dixo Don Quixote, fué el mayor enemigo que tuvo la Iglesia de Dios nuestro Señor en su tiempo y el vo la Iglesia de Dios nuestro Senor un su tempo, y el mayor defensor suyo que tendrá jamas, caballero andante por la vida, y santo á pie quedo por la mucrte, trabajador incen

or incansable en la vina del Sehor, $c c$ ij 
204

DON QUIXOTE DE LA MAXCHA

tes, á quicn sirvićron de escuelas los Cielos, y de catedrárico y maestro que le enseñase el mismo Jesuchristo. No habia mas imágines, y así mandó Don Quixote, que las volviesen á cubrir y dixo á los que las llevaban. por buen agüero he tenido, hermanos, haber visto lo que he visto, porque estos Santos y caballeros profesíron lo que yo profeso, que es el exercicio de las armas, sino que la diferencia que bay entre mí y cllos cs, que ellos fuéron Santos, y peleáron á lo divine, y yo soy pecador, y pcleo á lo humano. Ellos conquistáron el ciclo á fuerza de brazos, porque el cielo padece fuerza, y Yo hasta gora no sé lo que conquisto á fucrza de mis trabajos ; pero si mi Dulcinca del Toboso saliese de los que padece, mejorándose mi ventura, y adobánioseme el juicio, podria ser que encuminase mis pasos por mejor camino del que llero. Dios lo oiga , y el pecario sca sorjo dixo Sancho á esta ocasion. Admiráronsc los hombres, así de la figura, como de las razones de Don Quixote, sin entender la mitad de lo que en ellas decir queria. Acabáron de comer, cargáron con sus imágines, y despidiéndose de Don Quixore, siguiéron su viage. Qucdó Sancho de nuevo como si jamas hubiera conocido á su señor, admirado de lo que sabia, parcciéndole, que no debia de haber historia en el mundo, ni suceso, que no lo turiese cifrado en la una, $y$ clavado en la memo ria, y díxole : en verdad, señor nuestramo, que si esto que nos ha sucedido hoy, se puede llamar aventura, ella ha sido de las mas suaves y dulces que en todo el discurso de nuestra peregrinacion nos ha sucedido : della habemos salido sin palos y sobresalto alguno, ni hemos echado mano á las espadas, ni hemos batido la ticrra con
PARTEII. CAPITULO LVIIT 205 los cuerpos, ni quedamos hambrientos: bendito sea Dios, que tal me ha dexado ver con mis propios ojos. Tú dices bien, Sancho, dixo Don Quixote; pero has de advertir, que no todos los ticmpos son unos, ni corren de una misma sucrte: y csto que el vulgo suele llamar comunmente gä̈eros, que no se fundan sobre natural razon alouna, del que es discreto han de ser teniclos y juzgados por buenos acontecimicntos. Levántase uno destos agorcros por la mañana, sale de su casa, encuéntrase con un frayle de la órden del Bienaventurado": San Francisco, y como si hubicra encontrado con un grifo vuelve las espaldas, y vuélvese á su casa. Derrámasele al otro Mendoza la sal encima de la mesa, y derrámasele á él la melancolía por el corazon, como si esturicse obligadia la naturaleza á dar señales de las venideras desgracias con cosas tan de poco momento como las referidas. El "discreto y christiano no ha de andar en puntillos con lo que quiere hacer el Ciclo. Llega Cipion á Africa, tropieza en saltando en tierra, tiénenlo por mal agüero sus soldados; pcro él abrazándose con el suelo, dixo: no te me podrás huir, África, porque te tengo asida, y entre mis brazos. Así que, Sancho, el haber encontrato con estas imágines, ha sido para mí felicísimo acontecimiento. Yo así lo creo, respondió Sancho, y querria que vuesa merced me dixese ¿que es la causa por que dicen los Españoles, quando quicren dar alguna batalla, invocando aquel San Dicgo Matamoros : Santiago, y cierra España ? Está por ventura España abierta, $y$ de modo que es menester cerrarla? ¿ó que ceremonia es esta? Simplicísimo eres, Sancho, respondió Don Quixote, y mira que este gran caballero de la cruz bermeja, háselo dado Dios á Espa- 
206

DON QUIXOTE DE IA MANCHA

iia por Patron y amparo suyo, especialmente en los rigurosos trances que con los Moros los Españoles han tenido, y así le invocan y llaman, como á defensor suyo en todas las batallas que acometen, y muchas veces le han visto visiblemente en ellas, derribando, atropellando, destruyendo y matando los agarenos esquadrones : y desta verdad te pudiera traer muchos exemplos, que en las verdaderas historias españolas se cuentan. Mudó Sancho plática, y dixo á su amo: maravillado estoy, señor, de la desenvoltura de Aleisidora la doncella de la Duquesa : bravamente la debe de tener herida y traspasada aquel que llaman amor, que dicen que es un rapaz ceguezuelo, que con estar lagañoso, ó por mejor decir sin vista, si toma por blanco un corazon, por pequeño que sea, le acierta, y traspasa de parte á parte con sus flechas. He oido decir tambien, que en la vergücnza y recato de las doncellas, se despuntan y embotan las amorosas saetas; pero en esta Altisidora mas parece que se aguzan, que despuntan. Advierte, Sancho, dixo Don Quixote, que el amor, ni mira respetos, ni guarda términos de razon en sus discursos, y tiene la misma condicion que la muerte, que así acomete los altos alcázares de los Reyes, como las humildes chozas de los pastores, y quando toma entera posesion de una alma, lo primero que hace es quitarle el temor, y la vergüenza, y aś sin ella declaró Altisidora sus deseos, que engendráron en mi pecho ántes confusion, que lástima. Crueldad notoria, dixo Sancho, desagradecimiento inaudiro: yo de mí sé decir, que me rindiera y avasallara la mas minima razon amorosa suya. Hideputa i y que corazon de mármol, que entrañas de bronce, y que alma de ar-
PARTE II. CAPITULOLYIIT

gamasa! Pero no puedo pensar que es lo que vió esta doncella en vuesa merced que así la rindiese y avasnillase. ¿Que gala, que brio, que donayre, que rostro, que cada cosa por sí destas, ó todas juntas le enamoráron? Que en verdad, en verdad, que muchas veces me paro a mirar á vuesa merced desde la punta del pic hasta el último cabello de la cabeza, y que veo mas cosas para espantar, que para enamorar, y habiendo yo tambien oido decir, que la hermosura es la primera y principal parte que enamora, no teniendo vuesa merced ninguna, no sé yo de que se enamoró la pobrc. Advierte, Sancho, respondió Don Quixotc, que hay dos maneras de hermosura, una del alma, y otra del cuerpo: la del Ima camper, y se muestra en el entendimicnto, en la honestidad, en el buen proceder, en la liburalidad, y en la buena crianza, y todas estas partes caben, y pueden estar en un hombre feo, y quando se pone la mira en esta hermosura, $y$ no en la del cuerpo, suelen hacer el amor con ímpetu y con ventajas. Yo, Sancho, bien veo, que no soy hermoso, pero tambien conozco que no soy disforme : y bástale á un hombre de bien no ser monstruo para ser bien querido, como tenga los dotes del alma, oue tc he dicho. En estas razones y pláticas se iban entrando por una selva que fuera del camino cstaba, y á deshora, sin pensar en cllo, se halló Don Quixote enredado entre unas redes de hilo verde, que desde unos árboles á otros estaban tendidas, $y$ sin poder imaginar que pudiese ser aquello, dixo á Sancho: paréceme, Sancho, que esto destas redes debe de ser una de las mas nuevas aventuras que pueda imaginar. Que me maten si los encantadores que me persiguen, no quieren enredarme en 
cllas, y detener mi camino, como en venganza de la riguridad que con Altisidora he tenido: pues mándoles yo, que aunque estas redes, si como son hechas de hilo verde , fucran de durísimos diamantes, ó mas fuertes que aquella con que el zeloso Dios de los herreros enredó á Vénus y á Marte, así la rompiera como si fucra de juncos marinos, ó de hilachas de algodon: y queriendo pasar adelante, y romperlo todo, al improviso se le ofreciéron delante, saliendo de entre unos árboles, dos hermosísimas pastoras, aloménos vcstidas como pastoras, sino que los pellicos y sayas eran de fino brocado: digo que las sayas cran riquísimos falcellines de tabí de oro: traian los cabcllos sucltos por las espaldas, que en rubios podian competir con los rayos del mismo sol, los quales se coronaban con dos guirnaldas de verde laurcl, $y$ de roxo amaranto texidas: la edad, al parecer, ni baxaba de los cuince, ni pasaba de los diez y ocho. Vista fué esta que admiró á Sancho, suspendió á Don Quixote, hizo parar al sol en su carrera para verlas, y tuvo en maravilloso silencio á todos quatro. En fin quien primero habló fuć una de los dos zagalas , que dixo á Don Quixote : detened, scñor caballero, el paso, y no rompais las redes, que no para daño vucstro, sino para nuestro pasaticmpo ahí están tendidas: y porque sé que nos habcis de preguntar para que se han pucsto, y quien somos, os lo quicro decir en breves palabras. En una aldea que está hasta dos leguas de aquí, donde hay mucha gente principal, y muchos hidalgos y ricos, entre muchos amigos y parientes se concertó que con sus hijos, mugetes $\mathrm{y}$ hijas, vecinos, amigos $\mathrm{y}$ parientes, nos viniéscmos á holgar á este sitio, que es uno de los mas agrada-
PARTEII. CAPITULO IVIII.

bles de todos estos contornos, formando entre todos una nueva y pastoril Arcadia, vistićndonos las doncellas de zagalas y los mancebos de pastores: traemos estudiadas dos églogas, una del famoso poeta Garcilaso, y otra del excelentísimo Cámoes en su misma lengua portuguesa, las quales hasta agora no hemos representado: ayer fué el primero dia que aquí llegámos: tenemos entre estos ramos plantadas algunas tiendas, que dicen se llaman de campaña, en el márgen de un abundoso arroyo, que todos estos prados fertiliza : tendímos la noche pasada estas redes de estos árboles, para engañar los simples paxarillos, que oxeados con nuestro ruido vinieren á dar en cllas. Si gustais, señor, de ser nuestro huésped, seréis agasajado liberal y cortesmente, porque por agora en este sitio no ha de entrar la pesadumbre, ni la melancolía. Calló y yo dixo mas : á lo que respondió Don Quixote : por cierto, hermosísima señora, que no debió de quedat mas suspenso, ni admirado Anteon, quando vió al improriso bañarse en las aguas á Diana, como yo he quedado atónito en ver vuestra belleza. Alabo el asunto de vuestros entretenimientos, $y$ el de vuestros ofrecimientos agradezco, y si os puedo servir, con seguridad de ser obedecidas me lo podeis mandar, porque no es otra la profesion mia, sino de mostrarme agradecido y bienhechor con todo género de gente, en especial con Ia principal que vuestras personas representa: y si como estas redes, que deben de ocupar algun pequeño espacio, ocuparan toda la redondez de la tierra, buscara yo nuevos mundos por do pasar, sin romperlas: y porque deis algun crédito a csta mi exigeracion yed que os lo promete por lo ménos Don Quixore de la Mancha, si es тоM. IV. 
que ha llegado á vuestros oidos este nombre. ; Ay, amiga de mi alma, dixo entónces la otra zagala, y que ventura tan grande nos ha sucedido! ¿Ves este señor que tenemos delante? pues hágote saber que es el mas valiente, y el mas enamorado, y el mas comedido que tiene el mundo sino es que nos mienta y nos engañe una historia que de sus hazañas anda impresa, y yo he leido. Yo apostaré que este buen hombre que viene consigo es un tal Sancho Panza su escudero, á cuyas gracias no hay ninguras que se le igualen. Así es la verdad, dixo Sanclio, que yo soy ese gracioso, y ese escudero que vuesa merced dice, y este señor es mi amo, el mismo Don Quixote de la Mancha, historiado y referido. iAy! dixo la otra, supliquémosle, amiga, que se quede, que nuestros padres y nuestros hermanos gustarán infinito dello, que tambien he oido yo decir de su valor y de sus gracias lo mismo que tú me has dicho, y sobre todo dicen dél que es el mas firme y mas leal cnamorado que se sabe, y que su dama es una tal Dulcinea del Toboso, á quien en toda España la dan la palma de la hermosura. Con razon se la dan, dixo Don Quixote, si ya no lo pone en duda vuestra sin igual belleza : no os canseis, señoras, en detenerme, porque las precisas obligaciones de mi profesion no me dexan reposar en ningun cabo. Llegó en esto adonde los quatro estaban un hermano dc una de las dos pastoras, vestido asimismo de pastor, con la riqueza y galas que á las de las zagalas correspondia: contáronle ellas, que el que con ellas estabo era el valeroso Don Quixote de la Mancha, y el otro su cscudero Sancho, de quien tenia él ya noticia por haber leido su historia. Ofreciósele el gallardo pastor, pidióle que se viniese con él á sus tiendas,

PARTE II CAPfTUIO IVIIT 2 I I húbolo de conceder Don Quixote, y así lo hizo. Llegó en esto el oxeo, llenáronse las redes de paxarillos diferentes, que engañados de la color de las redes, caian en el peligro de que iban huyendo. Juntáronse en aquel sitio mas de treinta personas, todas bizarramente de pastores $y$ pastoras vestidas, $y$ en un instante quedáron enteradas de quienes eran Don Quixote y su escudero, de que no poco contento recibiéron, porque ya tenian dél noticia por su historia. Acudiéron á las tiendas, halláron las mesas puestas, ricas, abundantes y limpias : honráron á Don Quixote, dándole el primer lugar en ellas: mirábanle todos, y admirábanse de verle. Finalmente alzados los manteles, con gran reposo alzó Don Quixote la voz y dixo : entre los pecados mayores que los hombres cometen, aunque algunos dicen que es la soberbia , yo digo que es el desagradecimiento, ateniéndome á lo que suele decirse, que de los desagradecidos está lleno el infierno. Este pecado, en quanto me ha sido posible, he procurado yo huir desde el instante que tuve uso de razon, y si no pucdo pagar las buenas obras que me hacen con otras obras, pongo cn su lugar los deseos de hacerlas, y quando estos no bastan, las publico, porque quien dice y publica las bucnas obras que recibe , tambien las recompensara con otras si pudiera, porque por la mayor parte los que reciben son inferiores a los que dan, y así cs Dios sobre todos, porque es dador sobre todos $y$ no pueden corresponder las dádivas del hombre á las de Dios con igualdad, por infinita distancia, y esta estrecheza y cortedad en cierto modo la suple el agradecimiento. Yo pues, agradecido á la merced que aquí se me ha hecho, no pudiendo corresponrom. Iv. 
2 I 2

DON QUIXOTE DE IA MANCHA

der á la misma medida, conteniéndome en los estrechos límites de mi poderío, ofrezco lo que puedo, y lo que tengo de mi cosecha, y así digo que sustentare que tengo dese camino real que va a Zaragoza, que cstas señoras zagalas contrahechas que aquí están, son las mas hermosas doncellas y mas corteses que hay en cl mundo, excetando solo á la sin par Dulcinea del Toboso, única señora de mis pensamientos: con paz sea dicho de quantos y quantas me escuchan. Oyendo lo qual Sancho, que con grande atencion le habia estado escuchando, dancio una gran roz, dixo ‘es posible que haya en el mundo personas que se atrevan á decir y á jurar, que este mi señor es loco? Digan vuesas mercedes, scñores pastores ; hay Cura de aldea, por discreto y por estudiante que sca, que pueda decir lo que mi amo ha dicho? ; ni hay caballero andante, por mas que mi amo ha dicho ini hay afrecer lo que rama que tenga de valicnte que pucta frccer que mi amo aquí ha ofrecido? Volvióse Don Quixote á Sancho, y encendido el rostro y cólerico, le dixo à posible, ó Sancho, que haya en todo cl orbe alguna persona que diga que no eres tonto aforrado de lo mismo, con no sé que ribetes de malicioso y de bellaco ?: Quien te mete á ti en mis cosas, y en averiguar si soy discreto, majadcro? Calla, y no me repliques, sino ensilla, si está desensillado Rocinante: vamos á poner en efecto mi ofrecimicnto, que con la razon que va de mi parte puedes dar por vencidos á todos quantos quisieren contradecirla: y con gran furia y mucstras de enojo, se levantó de la silla dexando admirados á los circunstantes, haciéndoles dudar si le podian tener por loco, ó por cuerdo. Finalmente habiéndole persuadido, que no se pusicse
PARTEII CAṔTULO LVIIT.

en tal demanda, que ellos daban por bien conocida su chral temanda, que ellos daban por bien conocida su mostraciones para conocer su ánimo valeroso, pues bastaban las que en la historia de sus hechos se referian : con todo esto salió Don Quixote con su intencion , y puesto sobre Rocinante, embrazando su escudo, y tomando su lanza se puso en la mitad de un real camino, que no léxos del verde prado estaba. Siguióle Sancho sobre su rucio, con toda la gente del pastoral rebaño, deseosos de ver en que paraba su arrogante, y nunca visto ofrecimicnto. Puesto pues Don Quixote en mitad del camino, como os he dicho, hirió el ayre con scmejantes palabras: ó vosotros, pasageros y viandantes, caballcros, escuderos, gente de a pie y de á caballo, que por este camino $\mathrm{p}^{3-}$ sais, o habis de pasar en estos dos dias siguientes, sasais, ó habeis de pasar en estos dos dias siguientes, sabed que Don Quixote de la Mancha, caballero andante, está aquí puesto para defender, que á todas las hermosuras $y$ corresías del mundo exceden las que se encicrran en las Ninfas habitadoras destos prados y bosques, dexando á un lado á la Señora de mi alma Dulcinea del Toboso: por eso el que fucre de parecer contrario, acuda, que aquí le espero. Dos veces repitió escas mismas razones, y dos veces no fuéron oidas de ningun aventurero; pero la suerte que sus cosas iba encaminando de mejor en mejor, ordenó que de allí á poco se descubriese por el camino muchedumbre de hombres de á caballo $\mathrm{y}$ muchos dcilos con lanzas en las manos, caa caballo, y muchos declos con lanzas en las mies. minando todos apinados de tropel y á gran priesa. No los hubiéron bien visto los que con Don Quixote estaban, quando volviendo las espaldas se apartáron bien léxos de camino, porque conocićron que si esperaban, les po- 
214

DON QUIXOTE DE LA MANCHA

dia suceder algun peligro: solo Don Quixote con intréido corazon se estuvo quedo, y Sancho Panza se escudó con las ancas de Rocinante. Llegó el tropel de los anceros, y uno dellos que venia mas delante, á grandes voces comenzó á decir á Don Quixote: apártate, hom bre del diablo, del camino, que te harán pedazos estos toros. $\mathrm{E}_{2}$, canalla respondió Don Quixote, para mí no hay toros que valgan, aunque sean de los mas bravos que cria Xarama en sus riberas. Confesad, malandrines, as á carga cerrada, que es verdad lo que yo aquí he publicado si no, conmigo sois en batalla. No tuvo lugar de cado, si no, conmigo sois en bat responder el vaquero, ni Don Quixore le turo de desviarse, aunque quisiera, $y$ asi $\mathrm{cl}$ tropel de los toros bravos, y el de los mansos cabestros, con la multitud de los vaqueros, y otras gentes que á encerrar los llevaban á un Lugar, donde otro dia habian de correrse, pasáron sobre Don Quixote y sobre Sancho, Rocinante y el rucio, dando con todos ellos en ticrra, echándolos á rodar por el suelo. Quedó molido Sancho, espantado Don Quixore, aporreado el rucio, y no muy católico Rocinante; pero en fin se levantáron todos, y Don Quixote á gran pricsa, tropezando aquí, y cayendo allí, comenzó á correr tras la vacada, diciendo á voces : deteneos, y esperad, canalla malandrina, que un solo caballero os espera, el qual no tiene condicion, ni es de parecer de los que dicen que al enemigo que huye hacerle la puente de plata. Pero no por eso se detuviéron los apresurados corredores, ni hiciéron mas caso de sus amenazas, que de las nubes de antaño. Detúvole el cansancio á Don Quivote y mas enojado que vengado, se sentó en el camino, esperando á que Sancho, Rocinante y el
PARTEIT. CAPÍTULO LVIIT. 2I5 rucio llegasen. Llegáron, volviéron á subir amo y mozo, y sin volver á despedirse de la Arcadia fingida ó contrahecha, y con mas vergüenza que gusto, siguiéron su camino.

\section{CAPÍTULO IIX.}

Donde se cuenta el extraordinario suceso, que se puede tener por aventura, que le sucedió á Don Quixote.

Al polvo y al cansancio que Don Quixote y Sancho sacáron del descomedimiento de los toros socorrio una fuente clara y limpia, que entre una fresca arboleda hallíron, en el márgen de la qual, dexando libres, sin xáquima y freno al rucio y á Rocinante, los dos asendereados amo y mozo, se sentáron. Acudió Sancho á la repostería de sus alforjas, y dellas sacó de lo que él sojia llamar condumio : enjuagóse la boca, lavóse Don Quixote el rostro, con cuyo refrigerio cobráron aliento los espíritus desalentados : no comia Don Quixote de puro pesaroso, ni Sancho no osaba tocar á los manjares que delante tenil de puro comedido, y esperaba í que quen or hicicse la salva pero llevado de sus imaginaciones, no se acordaba de llevar el pan á la boca, no abrió la suya, y atropellando por todo género de crianza, comenzó á embaular en el estómago el pan y queso que se le ofrecia. Come, Sancho amigo, dixo qu que qu mí te imporra, y déxame morir á mí á manos de mis pensamientos, y á fuerza de mis desgracias. Yo, Sancho, nací para vivir muriendo, y tú para morir comiendo : y porque veas que te digo verdad en esto, considérame impreso cn historias, famoso en las armas, comedido en mis accio- 
nes, respetado de Príncipes, solicitado de doncellas, al cabo, al cabo, quando esperaba palmas, triunfos y coronas grangeadas y merecidas por mis valerosas hazanias, me he visto esta mañana pisado y acoccado, y molido de los pics de animales inmundos y soeces. Esta consideracion me embora los dientes, entorpece las muelas, y entomece las manos, y quita de todo en todo la gana del comer: demanera que pienso dexarme morir de hambre, muerte la mas cruel de las muertes. Desa manera, dixo Sancho, sin dexar de mascar apriesa, no aprobará vuesa merced aquel refran que dicen: muera Marta, y mucra harta : yo aloménos no pienso matarme á mí mismo; ántes pienso hacer como el zapatero, que tira el cuero con los dientes, hasta que le hace llegar donde él quiere : yo tiraré mi vida comiendo, hasta que llegue al fin que le tiene determinado el Cielo: y sepa, señor, que no hay mayor locura, que la que toca en querer desesperarse, como vuesa merced: $y$ créame, y despues de comido échese á dormir un poco sobre los colchones verdes destas yerbas, y verá como quando despierte se halla algo mas aliviado. Hízolo así Don Quixote, pareciéndole que las razones de Sancho mas eran de filósofo, que de mentecato, $y$ díxole : si tú , ó Sancho, quisieses hacer por mí lo que yo ahora te diré, serian mis alivios mas ciertos, $y$ mis pesadumbres no tan grandes, y es, que miéntras yo ducrmo, obedeciendo tus consejos tú te desviases un poco léxos de aquí, y con las riendas de Rocinante, echando al ayre tus carnes, te dieses trecientos, ó quatrocientos azote á buena cucnta de los tres mil y tantos que te has de dar por el desencanto de Dulcinea , que es lástima no peque- ña que aquella pobre Señora esté encantada por tu descuido y negligencia. Hay mucho que decir en eso, dixo Sancho: durmamos por ahora entrámbos, y despues Dios dixo lo que será. Sepa vuesa merced que esto de azotarse un hombre á sangre fria, es cosa recia, y mas si caen los azotes sobre un cuerpo mal sustentado, y peor comido : tenga paciencia mi Scñora Dulcinea, que quando ménos se cate me verá hecho una criba de azotes, $y$ hasta la muerte todo es vida: quiero decir, que aun yo la tengo, junto con el deseo de cumplir con lo que he prometido. Agradeciéndoselo Don Quixote, comió algo, y Sancho mucho, y echáronse á dormir entrámbos, derando á su albedrio, y sinórden alguna pacer de la abundosa yerba, de que aquel prado cstaba lleno, á los dos continuos compañeros y amigos, Rocinante y el rucio. Despertáron algo tarde, volviéron á subir y á seguir su camino, dándose priesa para llegar á una venta, que al parecer una legua de allí se descubria : digo que era venta, porque Don Quixote la llamó así, fuera del uso que tenia de llamar á todas las ventas castillos. Llegáron pues á ella : preguntáron al huésped, si habia posada. Fućles respondido que sí, con toda la comodidad y regulo que pudieran hallar en Zaragoza. Apcáronse, y recogrió Sancho su repostcría en un aposento, de quien el huésped le dió la llave. Llevó las bestias á la caballeriza chóles sus piensos, salió á ver lo que Don QuixoTiza, cchól sus picnos, salió a vero le mandabe dante, que cstaba sentado sobre un poyo, le mandaba, dando particulares gracias al Cielo de que á su amo no le hubiese parecido castillo aquella venta. Llegóse la hora de cenar, recogiéronse á su estancia : preguntó Sancho al huésped, que que tenia para darles de cenar. Á lo que rom. IV.
EE 
218

DON QUIXOTE DE LA MAXCH.

el huésped respondió, que su boca seria medida, y así que pidiese lo que quisiese, que de las paxaricas del ayre, de las aves de la tierra y de los pescados del mar cstaba proveida aquella venta. No es menester tanto, respondió Suncho, que con un par de pollos que nos asen tendirémos lo suficiente, porque mi seńor es delicato y come poco y yo no soy traganton en demáíl. Respondiólo ul huésped que no tenia pollos, porque los milanos las tenian asolados. Pues mande el señor huésped, dixo Sancho, asar una polla que sea ticrna. Polla, mi padre, respondió el huésped, en verdad en verdad que envié ayer á la ciudad á vender mas de cincuenca ; pero fuera de pollas, pida vuesa merced lo que quisicre. Dera manera, dixo Sanclio, no faltará ternera, ó cabrito. En casa por ahora, respondió el huésped, no lo hay, porque se ha acubado; pero la semana que viene lo habri de sobra. Medrados estamos con eso, respondió Sincho: yo pondré que se vienen á resumir todas estus fultas en las sobras que debe de haber de tocino y huevos. Por Dios, respondió el huésped, que es gentil relente el que mi huésped tiene : pues hele dicho, que ni tengo pollas, ni gallinas a quiere que tenga huevos: discurra, si quisicre, por otras delicadezas ${ }^{\prime \prime}$, déxese de pedir gallinas. Resolvámonos, cuerpo de mí, dixo Sancho":, y dígame finalmente lo que tiene, y déxese de discurrimientos. Señor huésped, dixo" el ventero, lo que real y verdaderamente tengo, son dos unas de vaca, que parecen manos de ternera, ó dos manos de ternera, que parecen uñas de vaca: cstín cocidas con sus garbanzos, cebollas y tocino, y la hora de ahora están diciendo: comeme, comeme. Por mias las marco desde aquí, dixo Sancho,
PARTEII. CAPITULO IIX.

y nadic las toque, que yo las pagaré mejor que otro, porque para mí ninguna otra cosa pudiera esperar de mas gusto, y no se me daria nada que fuesen manos, como fuesen uñas. Nadie las tocarí, dixo el ventero, porque otros luuéspedes que tengo, de puro principales traen consigo cocinero, despensero y repostería. Si por principales va, dixo Sancho, ninguno mas que mi amo; pero cl oficio que él trae, no permite despensas, ni botillerías: ahí nos tendemos en mitad de un prado, y nos hartamos de bellotas, ó de nísperos. Esta fué la plática que Sancho tuvo con el ventero, sin querer Sancho pasar adelante en responderle, que ya le habia preguntado que oficio ó que exercicio cra el de su amo. Llegóse pues la hora del cenar, recogióse á su estancia Don Quipues la hora el huésped la olla así como estaba, y sentóse á cenar muy de propósito. Parece ser que en otro pposento que junto al de Don Quixote estaba, que no posividi mas que un sutil tabique, oyó decir Don Quile dividia mas de vuesa merced, scñor Don Gerónimo, que en tanto que traen la cena leamos otro capítulo de la secunda parte de Don Quixote de la Mancha. A péns ó su nombre Don Quixote, quando se puso en pie, $y$ con oido alerto escuchó lo que dél trataban, y oyó que el tal Don Gerónimo referido respondió : ¿para que quicre vuesa merced, señor Don Juan, que leamos estos disparares, si el que hubiere leido la primera mos esros disparas parte de la historia de Don Quixote de la Mancha, no es posible que pucda tener gusto en !eer esta segunda? Con todo eso, dixo el Don Juan, será bien lecrla, pues no hay libro tan malo que no tenga alguna cosa buena. Lo que á mí en este mas desplace es, que pinta á Don Qui- 
xote ya desenamorado de Dulcinea del Toboso. Oyendo lo qual Don Quicore, lleno de ira, y de despecho, lzo la voz y divo: quien quiera que divere que Don Quixote de la Mancha ha olvidado, ni puede olvidar Dulcinea del Toboso, yo le haré entender con armas iguales, que va muy léxos de la verdad, porque la sin par pido: sublason es la firmeDon Quixote pue $z a, y$ su profesion el guardarla con suavidad, $y$ sin ha cerse fuerza alguna. ¿Quien es el que nos responde? respondiéron del orro aposento. Quien ha de ser, respondió Sancho, sino el mismo Don Quixote de la Mancha, que hará bueno quanto ha dicho, y aun quanto dixere, que al buen pagador no le duelen prendas. A pénas hubo dicho esro Sancho, quando entráron por la puerta de su aposento dos caballeros, que toles lo parecian, uno dellos echando los brazos al cuello de Don Quixote le dixo: ni vuestra presencia puede desmentir vuestro nombre, ni vuestro nombre puede no acreditar vuestra presencia Sin duda vos, señor, sois el verdadero Don Quixote de la Mancha, norte y lucero de la andante caballería, á despecho y pesar del que ha qucrido usurpar vuestro nombre, $y$ aniquilar vuestras hazañas, como lo ha hecho el autor deste libro, que aqui os entrego: y poniéndole un libro en las manos, que trais su compañero, le tomó Don Quixote, y sin responder palabra comenzó á hojearle, y de allí á un poco se le volvió, diciendo : en esto poco que he visto, he hallado tres cosas en este autor dignas de reprehension. La primera es, algunas palabras que he leido en el prólogo: la otra, que el lenguage es Aragones, porque tal vez escribe sin artículos, $y$ la tercera, que mas le confirma por ignorante, es que yerra, y se desvia de la verdad en lo mas principal de la historia , porque aquí dice, que la muger de Sancho Panza mi escudero se llama Mari Gutierrez, y no se llama tal, sino Teresa Panza, y quien en esta parte tan principal yerra, bien se podrá temer que yerra en todas las demas de la historia. Á esto dixo Sancho: donosa cosa de historiador por cierto, bien debe esar en el cuento de nuestros sucesos, pues llama á Teres Panz mi muger Mari Gutierrez : torne á tomar el libro, señor, y mire si ando yo por ahí, y si me ha mudado el nombre. Por lo que os he oido hablar, amigo, dixo Don Grónimo, sin duda debeis de ser Sancho Panin dio Sencho , ye precio dello. Pues á fe, dixo el cabaa fe, dixo el caballero, que no os trata este autor moderno con la limpieza que en vuestra persona se muestra: píntaos comedor, $y$ simple, y no nada gracioso, y muy otro del Sancho que en la primera parte de la historis de vuestro amo se describe. Dios se lo perdone, dixo Sancho, dexarame en mi rincon, sin acordarse de mí, porque quien las sabe las rañe, y bien se está San Pedro en Roma. Los dos caballeros pidiéron á Don Quixote se pasase á su estancia a cenar con ellos, que bien sabian que en aquella venta no habia cosas pertenecientes para su persona. Don Quixote que sicmpre fué comedido, condescendió con su demanda, y cenó con ellos: quedóse Sancho dió con subececon la olla con me mixto imperio, senó en cue Sanra de mesa, y con él el ventero, que no ménos que Sancho estaba de sus manos y de sus uñas aficionado. En el discurso de la cena preguntó Don Juan á Don Quixote, 
que nuevas tenia de la Señora Dulcinea del Toboso, si se habia casado, si estaba parida, ó preñada, ó si cstando en su entereza, se acordaba, guardando su honestidad buen decoro de los amorosos pensamientos del señor y buen decoro, de los amornsos pens. Dulcinea senor Don Quixote. A lo que él respondió : Dulcinca se est entera, y mis pensamientos mas firmes que nunca: las correspondencias en su scquedad antigua, su hermosura ch la de una socz labrodora transformada: y luego les fué contando punto por punto el encanto de la Señora Dulcinea, y lo que le habia sucedido en la cueva de Montesínos, con la órden que el sabio Merlin le habia dado terino los azotes de Sancho. con oir contar á Don Quixote los cxtraños succsos de su historia, y así quedáron admirados de sus disparates, como del clos contaba. Aquí le tenian por discreto, y allí se les deslizaba por mentecato, sin saber detcrminarse, que grado le darian entre la discrecion, y la locura. Acabó de cenar Sancho, y dexando hecho équis al ventero, se pasó á la estancia de su amo, y en entrando dixo: que me maten, señores, si el autor deste libro que vuesas mercedes tienen, quicre que no comamos buenas migas juntos, yo querria, que ya que me lloma comilon, como vuesas mercedes dicen, no me lix mo; pero no me acucrdo en que manera, aunque sé que son mal sonantes las razones, $y$ ademas mentirosas, segun yo echo de ver en la fisonomía del buen Sancho, que está presente. Créanme vuesas mercedes, dixo Sancho, que el Sancho, y el Don Quixote desa historia deben de ser otros, que los que andan en aquella que compu-
PARTEII. CAPÍTUIO IIX. 223

so Cide Hamete Benengeli, que somos nosotros: mi amo valiente, discreto y enamorado, y yo simple gracioso, y no comedor, ni borracho. Yo así lo creo, dixo Don Juan, y si fuera posible, se habia de mandar, que ninguno fuera osado á tratar de las cosas del gran Don Quivure, sino fuese Cide Hamete su primer autor, bien así como mandó Alexandro, que ninguno fuesc osado á retratarie sino Apéles. Retráteme el que quisiere, dixo Don Quixote; pero no me maltrate, que muchas veces suele caerse la paciencia, quando la cargan de injurias. Ninguna, dixo Don Juan, se le puede hacer al scinor Don Quixote, de quien él no se pueda vengar, si no la repara en el escudo de su paciencia, que á mi parecer es fucrte y grande. En cstas y otras pláticas se pasó gran parte de la noche, y aunque Don Juan quisicra que Don Quisote leyera mas del libro, por ver lo que discantaba, no lo pudiéron acabar con él, diciendo, que él lo daba por leido, y lo confirmaba por todo necio, y que no quesi acaso llegase á noricia de su autor, que le habia tcnido cn sus munos, se alegrase con pensar que le habia leido, pues cie las cosas obscenas $y$ torpes los pensamicntos se han de apartar, quanto mas los ojos. Pregunsumicnte su viagc. Respondió, que á Zaragoza á hallarse en las justas del arnes, que en aquella ciudad suelen hacerse todos los años. Díxole Don Juan, que aquella nueva historia contaba, comon Quixote sea quien se quisicre, se habia hallado mo the pobre de lecn ella en uni sortija, falta de tras, pobrísima de libreas, aunque rica de simplicidades. Por cl mismo caso, respondió Don Quixote, no pondré los pies en Zaragoza, y así sacaré á la plaza del mun- 
do la mentira dese historiador moderno, y ccharán de ver las gentes como yo no soy el Don Quixote que él dice. Hará muy bien, dixo Don Gerónimo, y orras justas hay cn Barcelona, donde podrá cl scinor Don Quixote mostrar su valor. Así lo pienso hacer, dixo Don Quixore, y vuesas mercedes me den licencia, pues ya es hora, para irme al lecho, y me tengan y pongan en el número de sus mayores amigos y servidores. $Y$ á mí tambien, dixo Sancho, quizá seré bueno para algo. Con csto se despidiéron, y Don Quixote y Sancho sc reriráron á su aposento dexando á Don Juan y á Don Gerónimo admirados de ver la mezcla, que habia hecho de sur discrecion y de su locura, y verdaderamente creyéron que estos cran los verdaderos Don Quixote y Sancho, y no los que describia su autor Aragones. Madrugó Don Quixote, y dando golpes al tabique del otro aposento, se despidió de sus huéspedes. Pagó Suncho al ventero magníficamente, y aconsejóle, que alabase ménos la provision de su venta, ó la tuviese mas proveida.

\section{CAPITULO LX.}

De lo que sucedió á Don Quixote yendo á Barcelona.

$\mathrm{E}_{\text {ra fresca la mañana, y daba muestras de serlo asimes- }}$ mo el dis en que Don Quixote salió de la venta, informándose primero, qual era el mas derecho camino para ir á Barcelona, sin tocar en Zaragoza : tal era el desco que tenia de sacar mentiroso aquel nuevo historiador, que tanro decian que le vituperaba. Sucedió pues, que en mas de seis dias no le sucedió cósa digna de ponerse en escritura, al cabo de los quales, yendo fuera de camino,
PARTEIT. CAPÍTULOLX. 225 le tomó la noche entre unas espesas encinas, ó alcornoques, que en esto no guarda la puntualidad Cide Hamete que en otras cosas suele. Apeáronse de sus bestias amo y mozo, y acomodándose á los troncos de los árboles, Suncho, que habia merendado aquel dia, se dexó entrar de rondon por las pucrtas del sueño ; pero Don Quixote, á quien desvelaban sus imaginaciones mucho mas que la hambre, no podia pegar sus ojos, ántes iba y venia con el pensamiento por mil géneros de lugares. Ya le parecia hallarse en la cueva de Montesínos, ya ver brincar $y$ subir sobre su pollina á la convertida en labradora Dulcinea, ya que le sonaban en los oidos las palabras del sabio Merlin, que le referian las condiciones y diligencias, que se habian de hacer y tener en el desencanto de Dulcinca. Desesperábase de ver la floxedad y caridad poca de Sancho su escudero, pues á lo que creia solos cinco azotes se habia dado, número desigual y pequeño para los infinitos que le faltaban: y desto recibió tanta pesadumbre y enojo, que hizo este discurso : si nudo Gordiano cortó el Magno Alexandro, diciendo : tanto monta cortar, como desatar, y no por eso dexó de ser universal Señor de toda la Asia, ni mas ni ménos podria suceder ahora en el desencanto de Dulcinea si yo azotase á Sancho á pesar suyo: que si la condicion deste remedio está en que Sancho reciba los tres mil y tantos azotes, que se me da á mí que se los dé él, ó que se los dé otro, pues la sustancia está en que él los reciba, lleguen por do liegaren. Con esta imaginacion se llegó á Sancho, habiendo primero tomado las riendas de Rocinante, y acomodándolas en modo que pudiese azotarle con ellas, comenzóle á quitar las cintas, que es opinion Tow. iv. 
226 DON QUIXOTE DE IA MANCHA

no tenir mas que la delantera, en que se sustentaban los gregüescos; pero apénas hubo llegado, quando ban Sancho desperto en todo su acue Yo yoy respondió Don to, quien me toca y desencinta? Yo soy, respondió Don Quixote, que vengo á suplir tus faltas, y á remediar mis trabajos : véngote á azotar, Sancho, y á descargar en parte la deuda á que te obligaste. Dulcinea perece, tú parte la deuda a quo te obuero deseando, y así desatácate vives en deschido, yo mia es de darte en esta soledad por tu voluntad, que la mia es de darte en esta soledad por 10 ménos dos mil azotes. Eso no, dixo Sancho, vuesa merced se esté quedo; si no, por Dios verdadero, que nos ha de oir los sordos: los azotes á que yo me oblinos han de oir los sordostios, $y$ no por fuerza, $y$ ahor gué, han de ser voluntarios, y no por fué no tengo gana de azotarme, basta que doy a vucsa merced mi palabra de vapularme y mosquearme quando en voluntad me vinicre. No hay dexarlo á tu cortesía, Sancoro dixon, cho, dixo Don Quixote, porque eres duró de coraba y aunque villano, blando de carnes: y así procuraba pugnaba por desenlazarle. Viendo lo qual Sancho Pan$\mathrm{za}$, se puso en pie, y arremetiendo á su amo, se abrazó con él brazo partido, y cchándole una zancadilla dió con élen el suclo boca arriba : púsole la rodilla dedió con él en el suclo boca ar las manos le tenia las marecha sobre el pecho, y con las manos le tenia las manos de modo, que ni le dexaba rodear, ni alentar. Do Quixote le decia ¿como traidor, contra tu amo y se Ror natural te desmandas? ; con quien te da su pan te hor natural te di Rey, ni pongo Rey, respondió Sancho, sino ayúdome á mí, que soy mi señor : vuesa merced me prometa que se estará quedo, y no tratara de azotarme por agora, que yo le dexaré libre y desembaazotar morirás traidor enemigo de Doña
PARTEIT. CAPITULO IX.

Sancha. Prometióselo Don Quixote, y juró por vida de sus pensamientos "no tocarle en el pelo de la ropa, y que dexaria en toda su voluntad y albedrío el azotarse quando quisiese. Levantóse Sancho, y desvióse de aquel lugar un buen espacio, y yendo á arrimarse á otro árbol, sintió que le tocaban en la cabeza, y alzando las manos, topó con dos pies de persona con zapatos y calzas. Tembló de miedo, acudió á otro árbol, y sucedióle lo mismo: dió roces llamando á Don Quixote, que le favoreciese. Hízolo así Don Quixote, y preguntándole, que le habia sucedido, y de que tenia miedo, le respondió Sancho, que todos aquellos árboles estaban llenos de pics y de piernas humanas. Tentólos Don Quixote, y ca yó luego en la cuenta de lo que podia ser, y díxole á Sancho: no tienes de que tener miedo, porque estos pies $\mathrm{y}$ piernas que tientas, $\mathrm{y}$ no ves, sin duda son de algunos foragidos y bandoleros, que en estos árboles están ahorcados, que por aquí los suele ahorcar la Justicia , quando los coge, de veinte en veinte y de treinta en treinta , por donde me doy á entender, que debo de estar cerca de Barcelona: y así era la verdad, como él lo habia imaginado. Al amanecer alzáron los ojos, y viéron los racimos de aquellos árboles, que eran cuerpos de bandoleros. Ya en esto amanecia, y si los muertos los habian espantado, no ménos los atribuláron mas de quarenta bandoleros vivos, que de improviso les rodcáron, diciéndoles en lengua catalana, que estuviesen quedos, y se detuviesen hasta que llegase sa Capitan. Hallóse Don Quixote á pie, su caballo sin freno, su lanza arrimada á un árbol , y finalmente sin defensa alguna, $\mathrm{y}$ así tuvo por bien de cruzar las manos, ć inclinar la cabeza suardanrom. Iv. 
228

DON QUTXOTE DE IA MANCHA

dose para mejor sazon y coyuntura. Acudiéron los bandoleros á espulgar al rucio, y á no dexarle ninguna cosa de quantas en las alforjas y la maleta traia : y avínole bicn' Sancho que en una ventiera "que tenia ceñida vien a Sancho quel Duque, y los que habian sacado de con todo cso aquella buena gente le escardara y le mirar hasta lo que entre el cuero y la carne tudara y le mirara hasta lo que en aquella sazon su Capitan el qual mostró ser de hasta edad de treinta y quatro añ tro antos, robusto, mas que de mis sobre un poderoso co mirar grave y color moren ballo, vestida la acerada cota, y con quatro pistoletes, que en aquella tierra se llaman pedreñales, á los lados Vió que sus escuderos (que así llaman á los que andan en aquel exercicio) iban á despojar á Sancho Panza : mandóles que no lo hiciesen, y fué luego obedecido, y así se escapó la ventiera ${ }^{42}$. Admiróle ver lanza arrimada al árbol, escudo en el suelo, y á Don Quixote armado y pensativo, con la mas triste y melancólice figura que pudier mas triste y melós dél diciéndole : no es formar la misma tisteza. teis tan triste, buen hombre, porque no habeis caido en las manos de algun cruel Osíris, sino en las de Ro que Guinart, que tienen mas de compasivas, que de rique Guinart, que tiench mas de compon Don Quivote, ha cula ber caido en tu poder, ó valeroso Roque, hay límites en la tierra que la encierren, sino por habe sido tal mi descuido, que me hayan cogido tus soldado in el freno estando yo obligado, segun la órden de la andante caballería que profeso, á vivir contino alerta, siendo á todas horas centinela de mí mismo: porque te hago saber, ó gran Roque, que si me hallaran sobre

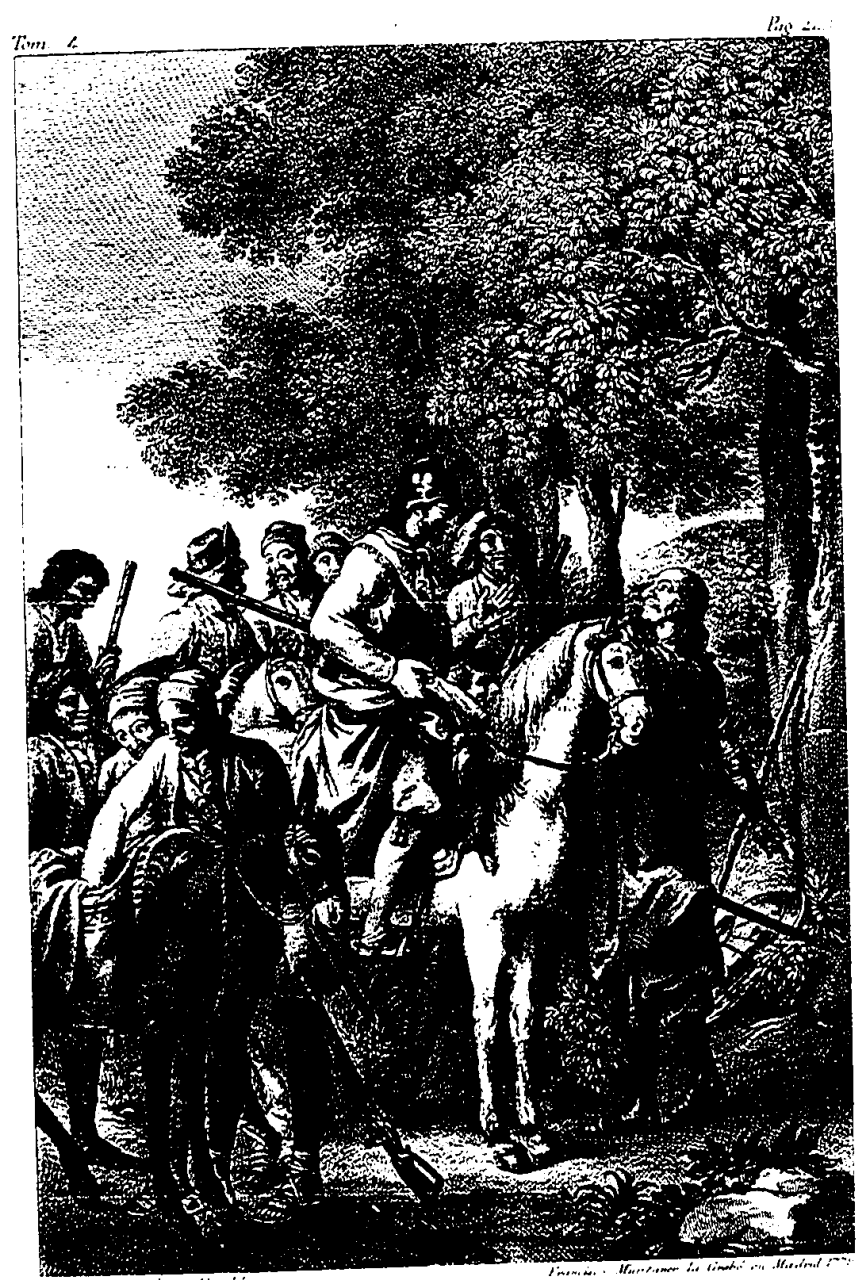


PARTE II. CAPÍIULO LX.

mi caballo con mi lanza y con mi escudo, no les fuera muy fácil rendirme, porque yo soy Don Quixote de Mancha, aquel que de sus hazañas tiene lieno todo el or be. Luego Roque Guinart conoció que la enfermedad de Don Quixote tocaba mas en locura, que en valentía, y aunque algunas veces le habia oido nombrar, nunca tuvo por verdad sus hechos, ni se pudo persuadir á que semejantc humor reynase en corazon de hombre, y holgóse en extremo de haberle encontrado, para tocar de cerca lo que de léxos dél habia oido, y así le dixo: valeroso caballero, no os despecheis, ni tengais á siniestra fortuna esta en que os hallais, que podria ser que en estos tropiczos vuestra torcida suerte se enderezase, que el Cielo por extraños, y nunca vistos rodeos, de los hombres no imaginados, suele levantar los caidos y enriquecer los pobres. Ya le iba á dar las gracias Don Quixote, quando sintiéron á sus espaldas un ruido como de tropel de caballos, y no era sino uno solo, sobre el qual venia á toda furia un mancebo, al parecer de hasta veinte años, vestido de damasco verde, con pasamanos de oro, gregüescos y saltaembarca, con sombrero terciado á la walona, botas enceradas y justas, espuelas, daga y espada doradas, una escopeta pequeña en las manos, y dos pistolas á los lados. Al ruido volvió Roque la cabeza, y vió esta hermosa figura, la qual en llegando á él, dixo: en tu busca venia, ó valeroso Roque, para hallar en tí, si no remedio, aloménos alivio en mi desdicha, $y$ por no tenerte suspenso, porque sé que no me has conocido, quiero decirte quien soy : yo soy Ciaudia Gerónima, hija

de Simon Forte tu singular amigo, y enemigo particular de Clauquel Torréllas, que asimismo lo es tuyo, por 
ser uno de los de tu contrario bando, $y$ ya sabes que este Torréllas ticne un hijo, que Don Vicente Torréllas Ilama, ó aloménos se llamaba no ha dos horas. Este pues, por abreviar el cuento de mi desventura, te diré en breves palabras la que me ha causado. Vióme, requebróme, escuchéle, cnamoréme á hurto de mi padre, porque no hay muser por retirada que esté y recatada que sea, á quien no le sobre tiempo para poner en execucion y efecto sus atropellados deseos. Finalmente, él me prometió de ser mi esposo, y yo le dí la palabra de me promes obremos adelante: supe ser suya, sin ayer, que olvidado de lo que me debia, se casaba con otra y que esta mañana iba á desposarse : nueva que me turbó el sentido, y acabó la paciencia, y por no estar mi padre en el Lugar, le tuve yo de ponerme en el trage que ves, y apresurando el paso á este caballo, alcancé á Don Vicente obra de una legua de aquí, y sin ponerme á dar quejas, ni á oir disculpas, le disparé esta escopeta, y por añ didura estas dos pistolas, y á lo que crco le de$y$ por anadidura estas dos pisolas, y lo que creóéndole puertas por donde envuelta en su sangre saliese mi honra. Alli le dexo entre sus criados, que no osáron, ni pudiéron ponerse en su defensa : vengo á buscarte, para que me pases á Francia, donde tengo parientes con quien viva, y asimesmo á rogarte defiendas á mi padre, porque los muchos de Don Vicente no se atrevan á tomar en él desaforada venganza. Roque admirado de la gallardía, bizarría buen talle y suceso de la hermosa Claudia, la dixo: ven, señora, y vamos á ver si es muerto tu encmigo, que despues verémos lo que mas te importare. Don Quixotc que estaba escuchando atentamente lo que
Claudia habia dicho, y lo que Roque Guinare respondió dixo: no tiene nadic para que tomar trabajo en defender á esta señora, que lo tomo yo á mi cargo : denme mi caballo y mis armas, y espérenme aquí, que yo iré á buscar á ese caballcro, y muerto, ó vivo le haré cumplir la palabra prometida á tanta belleza. Nadie dude de esto, dixo Sancho, porque mi señor tiene muy buena mano para casamentero, pues no ha muchos dias que hizo casar á otro que tambien negaba á otra doncella su palabra, y si no fuera porque los encantadores que le persiguen le mudíron su verdadera figura en la de un lacayo, esta fuera la hora que ya la tal doncella no lo fuera. Roque, que atendia mas á pensar en el suceso de la hermosa Claudia, que en las razones de amo y mozo, no las entendió, y mandando á sus escuderos, que volviesen á Sancho todo quanto le habian quitado del rucio, mandóles asimesmo que se retirasen á la parte donde aquella noche habian estado alojados, y luego se partió con Claudia á roda priesa á buscar al herido, ó muerto Don Vicentc. Llegáron al lugar donde le encontró Claudia, y no halláron en él sino recien derramada sangre; pero tendiendo la vista por todas partes, descubriéron por un recucsto arriba alguna gente, $y$ diéronse á entender, como cra la verdad, que debia de ser Don Vicente, á quien sus criados, ó muerto, ó vivo llevaban, ó para curarle , ó para enterrarle : diéronse pricsa á alcanzarlos, que como iban de cspacio, con facilidad lo hiciéron. Halláron á Don Vicente en los brazos de sus criados, á quien con cansada y debilirada voz rogaba, que le dexasen allí morir, porque el dolor de las heridas no consentia que mas adclante pasasc. Arrojáronse de los caba- 
232

DON QUIXOTE DE LA MANCHA

llos Claudia y Roque, llegáronse á él, temiéron los criades la en ver la dos la presencia de Rogue, ye Claudia se y rigurosa se de Don Vicente: $y$ asi entre enternecida y rigurosa, se llegó á él, y asiéndole de las manos, le dixo: si tú me dicras estas conforme á nuestro concierto, nunca tú dicras estas conformo. Abrió los casi cerrados ojos el herido vieras en este paso. Abró los casicia, le divo veo caballero, y conocicndo a Clauch, hermosa y engañada scinora, que tú has sido la que me has muerto: pena no merecida, ni debida á mis deseos, con muerto: pena no merecida, jamas quise, ni supe ofenlos quales, ni con mis obdad, dixo Claudia, que ibas esderte. : Luego no es verda , dixo Cla 1 hija del rico Balta manana a desposarte con vastro: No por cicrto, respondió Don Vicente, mi mala vastro? No por cicro llevar estas nuevas, para que zelosa fortuna te debio de la dexo en tus manos me quitases la vida, la qual pus la dexo en tus manos $y$ en tus brazos, tengo mi suerte por venturos: y para asegurarte desta verdad, apricta la mano, y recibene por esposo si quisieres, que no tengo ntra mayor satisfacion esposo, siensas que de mí has recebique darte del agravio que picnsa que déscle á ella el codo. Apretole la mano Clatidia, y apreoscle á ella el co razon, demanera que sobre la sangre y pecho de Don $V$ icente se quedó desmayada, $y$ á el le tomo un mortal parasismo. Confuso estabar Roque, y no sabia que hatal parasismo. Con criados á buscar agua que echarles cerse. Acudieron los criados a buscar agua quérín en los rostros, y truxeronla, con que se los bainiron. Volvió de su desmayo Claudia; pero no do su parasismo Don Vicente porque se le acabó la vida. Visto lo qual Don Vicio de Claudia, habichió los ayres con suspiros, hirió los poso no vivia, rompió los ayres con suspiros, hirió los cielos con quejas, maltrato su los al viento, afcó su rostro con sus propias manos, con parte ri. CApítUlo J.x.

todas las muestras de dolor $y$ sentimiento, que de un lastimado pecho pudieran imaginarse. ¡Ó cruel, é inconsidetimado pacilidad te moviste á poner icon que ficilita $O$ moviste a poner en execucion tan mal pensamiento! $i O$ fuerza rabiosia de los zclos, á que desesperado fin conducis á quien os da acogida en su pecho! : O esposo mio, cuya desdichada suere, por sur prenda mia te ha llevado del tálamo á la tan tirtes cran las quejas de Clautio sepultura! Tales y tan trises cran las quejas de Claudia que sacáron las lígrimas de los ojos de Roque, no acostumbrados á verterlas en ninguna ocasion. Lloraban lo criados desmarábase á cada paso Claudia, y todo aquel criado, desme destugar de desa circuito parccia campo ite triscza, y gar Finalmente Roque Guinart ordeno a los criados de Don Vicente, que llevasen su cucrpo al Lugar de su padre, que cstaba allí cerca, para que le diesen sepultura. Clatlque en dia dixo a Roque, que qucria irse ú un mona ba aca de era Abadesa una tia suya, en el qual pensaba acabar vida, de otro mcjor esposo y mas cterno acompanada Alabóle Roque su buen propósito, ofreciósele de acomAlabóle Roque subuender á su padre de panarla hasta donte quinicse, $y$ difender a sando si los parientes de Don Viectie, y de todo el mindo, si ofenderle quisiesen. No quiso su compañía Claudia en ninguna manera, y agradeciendo sus of:ccimientos con las guna manera, y agradeciendo sus desidio dél llorando. Los mejores razoncs que sup , sén du cuerpo, y Roque se criados de Don Vicente llevaron sti cuerpo, y Roque se volvióá los suyos: y este fin tuvicron los amores de Clautdia Gerónima. : Pero que mucho, si texicron la trama de su lamentable historia las fucrzas invencibles y rigurosas

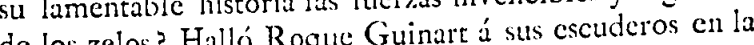
de los zelos? Hallo Roquo (ivinar a du cre parte donde les habia ordenado, $y$ á Don Quixote entre cllos sobre Rocinante, haciéndoles una plática, en que тoM. $\mathrm{N}$. 
234

DON QUTXOTE DE LA MANCHA

les persuadia dexasen aquel modo de vivir tan peligroso, así para el alma, como para el cuerpo ; pero como

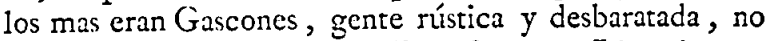
les entraba bien la plática de Don Quixote. Llegado que fué Roque, preguntó á Sancho Panza, si le habian vuelto $\mathrm{y}$ restituido las alhajas $\mathrm{y}$ preseas que los suyos del rucio le habian quitado. Sancho ${ }^{+3}$ respondió , que sí, sino que le faltaban tres tocadores, que valian tres ciudades. -Que es lo que dices, hombre? dixo uno de los presentes, que yo los tengo, y no valen tres reales. Así es, dixo Don Quixotc; pero estímalos mi escudero en lo que ha dicho, por habérmelos dado quien me los dió. Mandósclos volver al punto Roque Guinart, y mandando poner los suyos en ala, mandó tracr allí delante todos los vestidos, joyas $y$ dineros, $y$ todo aquello que desde la última reparticion habian robado, $y$ haciendo brevemente el tanreo, volviendo lo no repartible, y reduciéndolo á dineros, lo repartió por toda su compañia con tanta legalidad y prudencia, que no pasó un punto, ni defraudó nada de la justicia distributiva. Hecho esto, con lo qual todos quedáron contentos, satisfechos y pagados, dixo Roque á Don Quirote : si no se guardase esta puntualidad con estos, no se podria vivir con ellos. Á lo que dixo Sancho: segun lo que aquí he visto, es tan buena la justicia que es necesaria que se use aun entre los mesmos la drones. Oyolo un escudcro y yenarbelo el mocho de un arcabuz, con el qual sin duda le abricra la cabcza á Sancho, si Roque Guinart no le diera voces que se detuviese. Pasmóse Sancho, y propuso de no descoser los labios en tanto que entre aquella gente estuviese. Llegó en esto uno, ó algunos de aquellos escuderos, que estaban
PARTEII. CAPÍTULO IX.

puestos por centinelas por los caminos, para rer la gente que por ellos venia, $y$ dar aviso á su mayor de lo que pasaba, y este dixo: scinor, no léxos de aquí, por el camino que va á Barcelona viene un gran tropel de gente. A lo que respondió Roque: ¿ has echado de ver si son de los que nos buscan, ó de los que nosotros buscamos? To sino de los que buscamos, respondió cl escudero. Pucs salid todos, replicó Roque, y traédmelos aquí luego, sin que se os escape ninguno. Hiciéronlo así, y quedándose solos Don Quixote, Sancho y Roque, aguardáron á ver lo que los escuderos traian, $y$ en este entretanto dixo Roque á Don Quixote: nueva manera de vida le debe de parecer al señor Don Quixote la nuestra, nuevas aventuras, nuevos sucesos, y todos peligrosos: y no me mavillo que así le parezca, porque realmente le confieso, que no hay modo de vivir mas inquieto, ni confieso, que no hay muestro. A mí me han pucsto mas sobresaltado, que el nuestro. A mi me han pucsto de turbar los mas sosegados corazones : yo de mi naturol soy compasivo, y bien intencionado ; pero, como tengo dicho, el querer vengarme de un agravio que se me hizo, así da con todas mis buenas inclinaciones en tierra, que persevero en este estado á despecho, y pesar de lo que entiendo: y como un abismo llama á otro, y de lo que chticndo : y como uns ablabonado las renganun pecado a otro pecado, hanse eslabonado las renganzas demanera, que no solo las mias, pero las agenas tomo á mi cargo; pero Dios es servido de que aunque me veo en la mirad del laberinto de mis confusiones, no pierdo la salir dél á puerto seguro. Admirado do la esperanza de salir dé a puero seguro. Admiry quedó Don Quixote de oir hablar a Roque tan buenas conccradas razones, porque él se pensaba, que entre los ron. iv. 
236

DON QUIXOTE DE IA MANCHA

de oficios semcjantes de robar, matar $y$ saltear no podia haber alguno que tuviese buen discurso, y respondióle: señor Roque, el principio de la salud está en conocer la enfermedad, y en querer tomar el enfermo las medicinas que el médico le ordena: vuesa merced está enfermo, conoce su dolencia, y el Cielo, ó Dios, por mejor decir, que es nuestro médico, le aplicará medicinas que le anen las quales suelen sanar poco á poco, y no de repente y por milagro: y mas que los pecadores discretos están mas cerca de cmendarse, que los simples, y pues vuesa merced ha mostrado en sus razones su pruden cia no hay sino tener buen ánimo, y esperar mcjoria de la enfermedad de su conciencia : y si vuesa merced quiere ahorrar camino, $y$ ponerse con facilidad en el de su salvacion, véngase conmigo, que yo le enseñaré á ser caballero andante, donde se pasan tantos trabajos y desventuras, que tomándolas por penitencia, en dos paletas le pondrán en el Cielo. Rióse Roque del conscjo de Don Quixote, á quien mudando plática contó cl trígico suceso de Claudia Gerónima, de que le pesó en extremo í Sancho, que no le habia parecido mal la belleza, desenvoltura y brio de la moza. Llegáron en esto los escuderos de la presa, trayendo consigo dos caballeros á caballo y dos peregrinos á pie, y un coche de mugeres con hasta seis criados, que á pie y á caballo las acompañban con otros dos mozos de mulas que los caballeros traian. Cogiéronlos los escuderos en medio, guardando vencidos y vencedores gran silencio, esperando á que el gran Roque Guinart hablase, cl qual preguntó á los caballeros, que quien eran $y$ adonde iban, $y$ que dinero llevaban. Uno dellos le respondió : señor, noso-
PARTE IT. CAPÍTULO $\mathrm{LX}$.

tros somos dos Capitanes de Infantería Española, tenemos nuestras companías en Nápoles, y vamos á embarcarnos en quatro Galeras, que dicen estan en Barcelona, con órden de pasar á Sicilia : llevamos hasta docientos, ó trecientos escudos, con que á nuestro parecer vamos ricos y contentos, pues la estrecheza orcinaria de los soldados no pernite mayores tesoros. Preguntó Roque á los peregrinos lo mesmo que á los Capitanes : fucile respondido, que iban á embarcarse para pasar á Roma, y que entre entrámbos podrian llevar hasta sesenta reales. Quiso saber tambien, quien iba cn el coche $y$ adonde, y el dinero que llevaban : y uno de los de á caballo di xo: mi señora Doña Guiomar de Quiñónes, muger del Regente de la Vicaría de Nápoles, con una hija pequera una doncella y una ducina son las que van en el coche : acompañámosla seis criados, y los dineros son seiscientos escudos. De modo, dixo Roque Guinart, que Ya tencmos aquí norecientos escudos y sesenta reales: mis soldados deben de ser hasta sesenta, mírese á como le cabe á cada uno, porque yo scy mal contador. Oyendo decir esto los salteadores, levantíron la voz, diciendo: viva Roque Guinart muchos años, á pesar de los lladres, que su perdicion procuran. Mostráron afligirse los Capitanes, entristecióse la señora Regenta, y no se holgúron nada los peregrinos, viendo la confiscacion de sus bicnes. Túvolos así un rato suspensos Roque ; pero no quá qu prolviéndose á los Capitanes, divo : vesos mercedes señores Capitanes, por cortesia prestarne sescra cicudos, la seña sean servidos de prestarme sesenta escudos, y la senora Regenta ochenta, para contentar esta escuadra que me 
$23^{8}$

DON QUIXOTE DE IA MANCHA

acompaña, porque el Abad de lo que canta yanta, y luego puédense ir su camino libre y desembarazadamente, con un salvoconduto que yo les daré, para que si toparen otras de algunas escuadras mias, que tengo divididas por estos contornos, no les hagan daño, que no es mi intencion de agraviar á soldadios, ni á muger alguna especialmente á las que son principales. Infinitas y bien dichas fuéron las razones con que los Capitanes agradeciéron á Roque su cortesía y liberalidad, que por tal la tuviéron en dexarles su mismo dincro. La scñora Doña Guiomar de Quińónes se quiso arrojar del coche para besar los pics y las manos del gran Roque; pero ćl no lo consintió en ninguna manera; ántes le pidió perdon del agravio que le habia hecho, forzado de cumplir con las obligaciones precisas de su mal oficio. Mandó la señora Regenta á un criado suyo diese luego los ochenta escudos que le habian repartido, y ya los Capitanes habian desembolsado los sesenta. Iban los peregrinos á dar toda su miseria ; pero Roque les divo, que se estuviesen quedos, y volviéndose á los suyos, les dixo : destos escudos dos tocan á cada uno y sobran veinte, los diez se den á estos peregrinos, y los otros diez á este buen escudero, porque pueda decir bien de esta aventura : y trayéndole aderezo de escribir, de que sicmpre andaba proveido Roque, les dió por escrito un salvoconduto para los mayorales de sus escuadras, y despidiéndose dellos, los dexó ir libres y admirados de su nobleza, de su gallarda dispesicion y extraño proceder, teniéndole mas por un Alexandro Magno, que por ladron conocido. Uno de los escuderos diro en su lengua, gascona y catalana : este nuestro $\mathrm{Ca}$ pitan, mas es para Frade, que para bandolero : si de
PARTE II. CAPÍTULO IX.

aquí adelante quisicre mostrarse liberal, séalo con su hacienda, y no con la nuestra. No lo dixo tan paso el desventurado, que dexase de oirlo Roque, el qual echando mano á la espada, le abrió la cabeza casi cn dos partes, diciéndole : desta manera castigo yo á los deslenguados y atrevidos. Pasmáronse todos, y ninguno le osó decir palabra: tanta cra la obediencia que le tenian. Apartóse Roque á una parte, y escribió una carta á un su amigo á Barcclona, dándole aviso como estaba consigo $\mathrm{cl}$ famoso Don Quixote de la Mancha, aquel caballero andante de quien tantas cosas se decian: y que le hacia saber, que era el mas gracioso, y el mas entendido hombre del mundo, y que de allí á quatro dias, que era el de San Juan Bautista, se le pondria en mitad de la playa de la ciudad, armado de todas sus armas, sobre Rocinante su caballo, y á sul escudero Sancho sobre un asno, y que diese noticia desto á sus amigos los Niárros, para que con él se solazasen, que él quisiera que carecieran deste gusto los Cadells sus contrarios, pero que esto era imposible, á causa que las locuras y discreciones de Don Quixore, y los donayres de su escudero Sancho Panza, no podian dexar de dar gusto general á todo el mundo. Despachó estas cartas con uno de sus escuderos, que mudando cl trage de bandolero en el de un labrador, entró en Barcelona, y la dió á quien iba.

\section{CAPÍTULO LXI.}

De lo que le sucedió á Don Quixote en la entrada de Barcelona, con otras cosas que tienen mas de lo verdadero, que de lo discreto.

$\mathbf{T}_{\text {res dias y tres noches cstuvo Don Quixote con Ro- }}$ 
que, $y$ si estuviera trecientos años no le faltara que mirar y admirar en el modo de su vida. Aquí amanecian, acullá comian: unas veces huian sin saber de quien, $y$ actras có quien. Dormian en pie, interrompiendo el sucño, mudándose de un lugar a otro. rodo era poner espías, escuchar centinelas, soplar las cuerdas de los arcabuces, aunque traian pocos, porque todos se servian de pedreńales. Roque pasaba las noches apartado de los suyos en partes y lugares clonde cllos no pudiesen saber donde estaba, porque los muchos bandos que el Visorey de Barcelona habia echado sobre su vida, le traian inquicto y temcroso, y no se osaba fiar de ninguro temiendo que los mismos suyos, ó le habian ninguno, temiendo que los mismos susta por cicrto mide matar, ó entregar a la Justicia : vida por cicro miatnjos y sendas encubiertas, partiéron Roque, Don Quiatajos y sancho con otros seis escuderos á Barcelona. Llexote y Sanchocon otros seis ercuderos a Barclona. Llegáron á su playa la víspera de San Juan en la noche, yabrazando Roque á Don Quixote y á Sancho, á quien dió los diez escudos prometidos, que hasta entónces no se los hio dado, los deró con mil ofrecimicntos que se los habia dadóse Roque de la una a la otra parte se hicierron. quedóse Don Quixote esperando el dia así á caballo como estaba, y no tardó mucho, quando comenzó á descubrirse por los balcones del oriente la faz de la blanca cubrirse por los bas fores, en lugar de alegrar el oido, aunque al mesmo instante alegráron tambien el oido el son de muchas chirimías y atabales, ruido de cascabeles, trapa, trapa, aparta, aparta de corredores, que al parecer de la ciudad salian. Dió lugar la aurora al sol, que un rostro mayor que el de una rodela por el mas baxo orizonte, poco a poco se iba levantando. Tendiéron Don Quixote y Sancho la vista por todas partes, viéron el mar, hasta entónces dellos no visto : parccióles espaciosísimo y largo, harto mas que las lagunas de Ruidera, que en la Mancha habian visto. Viéron las galeras que estaban on la playa, las quales abaticndo las tiendas, se descubrićron llenas de flámulas $y$ tiendo las tiendes, que tremolaban al viento, y besaban y barrian el agua : dentro sonaban clarines, trompetas y chirimís, que cerca y léxos llenaban el ayre de suaves $y$ belicosos acentos : comenzáron á moverse, y á hacer un modo de escaramuza por las soscgadas aguas, corresponmodo de escaramuza por las sosegudas aguas, concsponde la ciudad sobre hermosos caballos y con vistosas libreas salian. Los soldados de las galeras disparaban infinita artillería, á quien respondian los que estaban en las murallas y iuertes de la ciudad, y la artillería gruesa con cepantoso estruendo rompia los vientos, á quien respondian los cañones de cruxía de las galeras. El mar alegre, da la ticra jo iba infundiendo y enhumo de la artilleria, parce cue iba infundiento y engendrando gusto súbito en todas las gentes. No podia imaginar Sancho como pudiescn tener tantos pies aquellos ginar Sanclio como purse movian. En esto llegáron corbultos, que por cl ililícs y algazara los de las libreas, riendo con grita, lillics y algazán los de las libras, adonde Don Quixote suspenso y atonito estaba, y uno dellos, que era el avisado de Roque, dixo en alta voz a Don Quixote : bien sea venido á nuestra ciudad el csa Don estrella ${ }^{\text {th }}$ y el norte de toda la cabapejo, el farol , la cste mas largamente se conticne. Bien llería andante, donde mas largamen se conico de sea venido, digo, el valcroso Don Qui. TOM. Y. 
cha: no el falso, no el ficticio, no el apócrifo, que en falias historias estos dias nos han mostrado, sino el verdadero, el legal y el fiel, que nos describió Cide $\mathrm{Ha}$ mete Benengeli, flor de los ${ }^{* 7}$ historiadores. No respondió Don Quixote palabra, ni los caballeros esperíron á que la respondicse, sino volviéndose y revolviéndose con los demas que los seguian, comenzáron á hacer un revuelto caracol al derredor de Don Quixote, cl qual volviéndosc í Sancho, dixo: estos bien nos han conocido, yo apostaré que han heido nuestra historia, $y$ aun la del Arogones recien impresa. Volvió otra vez el caballero que habló á Don Quixote, y díxole : ruesa merced, señor Don Quixote, se venga con nosotros, que todos somos sus servidores y grandes amigos de Roque Guinart. A lo que Don Quixote respondió : si cortesías engendran cortesías, la vucstra, señor caballero, cs hija, ó parienta muy cercana de las del gran Roque : llevadme do quisiéredes, que yo no tendré otra voluntad que la vuestra, y mas si la quereis ocupar en vuestro servicio. Con palabras no ménos comedidas que cstas le respondió el caballero, y encerríndole todos en medio, al son de las chirimías y de los atabales, se encamináron con él á la ciudad: al cntrar de la qual, el malo, que todo lo malo ordena, y los muchachos que son mas malos que el malo, dos dellos traviesos y atrevidos se entrúron por toda la gente, y alzando el uno de la cola del rucio, y el otro la de Rocinante, les pusiéron y encaxáron sendos manojos de aliagas. Sintiéton los pobres animales las nuevas espuelas, $y$ apretando las colas, aumentáron su disgusto, demanera, que dando mil corcovos, diéron con sus dueños en tierra. Don Quixote, corrido y afrentado, acudió á quitar el plumage de la cola de su matalote, $y$ Sancho el de su rucio. Quisieran los que guiaban á Don Quixote castigar el atrevimiento de los muchachos, y no fué posible, porque se encerráron entre mas de otros mil que los seguian. Volviéron á subir Don Quixote y Sancho, y con el mismo aplauso y música llegáron á la casa de su guia, que era grande y principal, en fin como de caballero rico, donde le dexarémos por agora, porque así lo quiere Cide Hamete.

\section{CAPÍTULO LXII.}

Oue trata de la aventura de la cabeza encantada, con otras niñ̄erias, que no pueden dexar de contarse.

Don Antonio Moreno se llamaba el huésped de Don Quixote, caballero rico y discreto, y amigo de holgarse á lo honesto y afable, el qual viendo en su casa á Don Quixote, andaba buscando modos como sin su perjuicio sacase á plaza sus locuras, porque no son burlas las que duelen, ni hay pasatiempos que valgan, si son con daño de tercero. Quict Quixote, y sacarle a vistas con aquel sa estrecho y acamuzado vestido (como ya otras veces le hemos descrito y pintado) á un balcon, que salia á una calle de las mas principales de la ciudaj, á vista de las gentes y de los muchachorriéron de nucvo chos, que como a mona le miraban. Corrieron de nucvo delante dél los de las libreas, como si para él solo, no para alegrar aquel festivo dia, se las hubieran puesto, $y$ Sancho estaba contentísimo, por parecerle que se habia bia hallado, sin saber como, ni co Don Dicgo de Mide Camacho, otra casa como la de Don Diego de Miranda, y otro castillo como el del Duque. Comiéron aquel TOM. IV. 
dia con Don Antonio algunos de sus amigos, honrando todos , y tratando á Don Quixote como á caballero andante, de lo qual hucco y pomposo no cabia en sí de contento. Los donayres de Sancho fuéron tantos, que de su boca andaban como colgados todos los criados de casa , y todos quantos le oian. Estando á la mesa, dixo Don Antonio á Sancho : ací tenemos noticia, buen Sancho, que sois tan amigo de manjar blanco y de albondiguillas, que si os sobran las guardais en el seno para el orro dia. No señor, no es así, respondio Sancho, porque tengo mas de limpio que de goloso, y mi señor Don Quixote, que cstá delante, sabc bien que con un puño de bellotas, ó de nueces nos solemos pasar entrambos ocho dias: verdad es que si tal vez me sucede, que me den la vaquilla, corro con la soguilla : quiero decir, que como lo que me dan, y uso de los tiempos como los hallo, y quien quiera que hubiere dicho que yo soy comedor aventajado, y no limpio, téngase por dicho que no acicrta, y de otra mancra dixera esto, si no mirara á las barbas honradas que estún á la mesa. Por cierto, dixo Don Quixote, que la parsimonia y limpieza con que Sancho come, se puede escribir y grabar en láminas de bronce, para que quede en memoria eterna en los siglos venideros. Verdad es que quando él tiene hambre, parece algo tragon, porque come apriesa , y masca á dos carrillos; pero la limpieza sicmpre la tiene en su punto, $y$ cn el ticmpo que fué Gobernador aprendió á comer á lo melindroso, tanto que comia con tenedor las uvas y aun los granos de la granada. ¡Como! dixo Don Antonio ¿ Gobernador ha sido Sancho? Sí, respondió Sancho $y$ de una Ínsula llamada la Barataria. Diez dias la gobernéá pe- dir de boca: en ellos perdí cl sosicgo, y aprendí á despreciar todos los Gobiernos del mundo : salí huyendo della, caí en una cueva donde me tuve por muerto, de la qual salí vivo por milagro. Contó Don Quixote por menudo todo el suceso del Gobierno de Sancho, con que dió gran gusto á los oyentes. Levantados los manteles, y tomando Don Antonio por la mano á Don Quixote, se cntró con él en un apartado aposento, en el qual no habia otra cosa de adorno que una mesa, al parecer de jaspe, que sobre un pie de lo mesmo se sostenia, sobre la qual estaba puesta al modo de las cabezas de los Emperadores Romanos, de los pechos arriba, una que semejaba ser de bronce. Pascóse Don Antonio con Don Quixote por todo el aposento, rodeando muchas veces la mesa : despues de lo qual dixo : agora, Señor Don Quixote, que estoy enterado que no nos oye y escucha alguno, y está cerrada la puerta, quiero contar á vucsa merced una de las mas raras aventuras, ó por mejor decir novedades que imaginarse pueden, con condicion que lo que á vuesa merced dixere, lo ha de depositar en los últimos retretes del secreto. Así lo juro, respondió Don Quixote, y aun le echaré una losa encima para mas seguridad, porque quiero que sepa vuesa merced, scñor Don Antonio (que ya sabia su nombre) que está hablando con quien, aunque tienc oidos para oir, no tiene lengua para hablar, así que con seguridad pucde vuesa merced trasladar lo que tiene en su pecho en el mio, $y$ hacer cuenta que lo ha arrojado en los abisen cl mio, mos del silencio. En fe desa promesa, respondió Don Antonio, quiero poner á vuesa merced en admiracion con lo que viere y oyere, y darme á mí algun alivio de 
DON QUIXOTE DE IA MANCHA

la pena que me causa no tener con quien comunicar mis secretos, que no son para fiarse de todos. Suspenso estaba Don Quixote, esperando en que habian de parar tantas Don Quixóndo la mano Don Antoprevencioncs. En csta, tomandole la mano Don Anto rio, se la pascó por la cabcza de bronce, y por toda la mesa, y por el pie de jaspe, sobre que se sostenia, y mesa, y por cl pic cabeza, scñor Don Quixote, ha sido luego dico ma de los mores encantadores hecha y fabricada por uno de los mando, que creo era Pola $\mathrm{y}$ hechiceros que ha tenido el mundo, que creo era Polaco de nacion, $y$ discípulo del famoso Escotillo, de quien tantas maravillas se cuentan, el qual estuvo aquí en mi casa, y por precio de mil escudos, que le dí, labró escasa, por precio de propiedad y virtud de responder ta cabeza, que ticn propiedad y virud de responder á quantas cosas al oido le preguntaren. Guardó rumbos, pintó caractéres, observó astros, miró puntos, y finalmente la sacó con la perfeccion que verćmos mañana, porque los viérnes estí cos esperar hasta manana. En este tiempo podra vuesa merced prevenirse de lo que querrá preguntar, que por experiencia sé que dice verdad en quanto responde. Admiperien qué Don Quixore de la virtud y propiedad de raco quedo Don Quixore de la vir Don Antonio; pero la cabcza, y cstuvo por no crecr á Don Antonio; pero por ver quan poco tiempo habia para hacer la experiencia, no quiso decirle otra cosa, sino que le agradecia el haberle descubicrto tan gran secreto. Saliéron del aposencré diave, $y$ fuéronse to, cerró la pucrta Don Antonio con tlave, y fur á la sala, donde los demas caballeros estaban. En est tiempo les habia contado Sancho muchas de las aventuras y sucesos que á su amo habian acontecido. Aquella tarde sáron á pasear á Don Quixore, no armado, sino de rua, vestido un balandran de paño leonado, que pu-
PARIEII. CAPÍTULO LXIT. 247 diera hacer sudar en aquel tiempo al mismo yclo. Ordenáron con sus criados que entretuviesen á Sancho, de modo, que no le dexasen salir de casa. Iba Don Quixote, no sobre Rocinante, sino sobre un gran macho de paso llano, y muy bien aderezado. Pusiéronle el balandran, y en las espaldas, sin que lo viese, le cosiéron un pergamino, donde le escribiéron con letras grandes: Esti es Don Quixote de la Mancha. En comenzando el pasco, llevaba el rétulo los ojos de quantos venian á verle, y como leian : cste es Don Quixote de la Mancha, admirábase Don Quixote de ver, que quantos le miraban, le nombraban y conocian, y volviéndose á Don Antonio, que iba á su lado, le divo: grande es la prerogativa que encierra en sí la andante caballería, pues hace conocido y famoso al que la profesa por todos los términos de la tierra: si no, mire vuesa merced, señor Don Antonio, que hasta los muchachos desta ciudad, sin nunca haberme visto me conocen. Así es, seinor Don Quixote, respondió Don Antonio, que así como cl fuego no puede estar escondido y encerrado, la virtud no puede dexar de ser conocida, y la que se alcanza por la profesion de las armas, resplandece $y$ campea sobre todas las otras. Acaeció pucs, que yendo Don Quixote con el aplauso que se ha dicho, un Castellano, que leyó el rétulo de las espaldas, alzó la roz, diciendo: válgate el diablo por Don Quixote de la Mancha, como ¿que hasta aquí has llegado sin haberte mucrto los infiniros palos que tienes ${ }^{\star s}$ á cuestas? Tú eres loco, y si lo fucras á $y$ si lo fucras a solas, $y$ dentro de las pueras de tacura, fuera ménos mal; pero tienes propiedad de volver locos y mentecatos á quantos te tratan y comunican : si 
248

DON QUIXOTE DE LA MANCHA

no, mírenlo por estos señores que te acompanan. Vuélvete, mentecato, á tu casa, y mira por tu hacienda, por tu muger y tus hijos, y déxate destas vaciedades, que tu miser mano, dixo Don deis consejos á quien no os los pide. El scñor Don Quixote de la Mancha es muy cuerdo, y nosotros, que le acompring no somos necios: la virtud se ha de honrar donde quicra que se hallare, $y$ andad en hora mala, y no os metais donde no os llaman. Par diez vuesa merced tiene razon, respondió el Castellano, que aconsejar á este buen hombre es dar coces contra el aguijon; pero con todo eso me da muy gran lástima, que el buen ingenio que dicen que tiene en todas las cosas este mentecato, sc le desagüe por la canal de su andante caballería: y la en lora mala que vuesa merced dixo, sea para i y la en hara mis qescendientes, si de hoy mas, mi y para todos mis descendientes, si de hoy aunque vivicse mas años que Matusalen, dicre consejo á nadie, aunque me lo pida. Apartóse el conscjero, siguió adelante el paseo; pero fué tanta la priesa que los muchachos y toda la "gente tenia leyendo cl rétulo, que se le hubo de quitar Don Antonio, como que le quitaba otra cosa. Llegó la noche, volviéronse á casa, hubo sarao de damas, porque la muger de Don Antonio, que era uni seínora principal y alcgre, hermosa y discreta, convidó á otras sus amigas á que viniesen á honrar á su huésped, y á gustar de sus nunca vistas locuras. Viniéron algunas, cenóse espléndidamente, y comenzóse el sarao casi á las dicz de la noche. Entre las damas habia dos de gusto pícaro y burlonas, y con ser muy honestas, eran algo descompuestas, por dar lugar que las burlas alegra-
PARTEIT. CAPÍTULO IXIT.

sen sin enfado. Estas diéron tanta priesa en sacar á danzar á Don Quixote, que le moliéron, no solo el cuerpo, pero el ánima. Era cosa de ver la figura de Don Quixote, largo, tendido, flaco, amarillo, estrecho en el vestido, desayrado, y sobre todo, no nada ligero. Requebrábanle como a hurto las damiselas, y él tambien como á hurto las desdeñaba; pero viéndose apretar de requiebros, alzó la voz, y dixo : Fígite partes adversac: dexadme en mi sosieco, pensamientos malvenidos, allá os avenid, señoras, con vuestros deseos, que Ia que es Reyna de los mios, la sin par Dulcinea del Toboso no consiente que ningunos otros que los suyos me avasallen y rindan: y diciendo esto se sentó en mirad de la sala en el suelo, molido y quebrantado de tan baylador exercicio. Hizo Don Antonio que le llevasen en peso á su lecho, y el primero que asió dél, fué Sancho, diciendole : nora en tal, señor nuestro amo, lo habeis baylado: ; pensais que todos los valientes son danzadores, $\mathrm{y}$ todos los andantes caballeros baylarines? Digo, que si lo pensais, que estais engañado: hombre hay que se atreverá á matar a un gigante, ántes que hacer una cabriola : si hubiérades de zapatear, yo suplicra vucstra falta, que zapateo como un girifalte, pero en lo del danzar no doy puntada. Con estas y otras razones dió que rcir Sancho á los del sarao, y dió con su amo en la cama, arropíndole para cue sudase la frialdad de su bayle. Otro dia le pareció a Don Antonio ser bien hacer la experiencia de la cabeza encantada, y con Don Quixote, Sancho y otros dos amigos, con las dos señoras que habian molido á Don Quirote en cl bayle, que aquella propir nuche se habian quedado con la muger de Don Antonio, se encerró en la тom. $\mathrm{rV}$ 
250

DON OUIXOTE DE IA MANCHA

estancia donde estaba la cabeza. Contóles la propiedad que tenia, encargóles el secreto, y díxoles, que aquel que tenia, enco dia da virud de la tal cabeza encantada, y si no eran los dos amigos de Don Antonio , ninguna otra persona sabia el busílis del encanto, y aun si Don Antonio no se le hubiera desdel encanto, y aun cubicrto primcro á sus amigos, rambicn ellos caycran en la admiracion en que los demas cayeron, sin ser posible otra cosa: con tal traza y tal órden estaba fabricada. El primero que se llegó al oido de la cabeza, fué cl mismo Don mero que sellego al co vumisa, pero no tanto que de Antonio, y dixole cn voz sumisa, pero no gn que de todos no fuese entendida: dime, cabeza, por la virtud que en tíse encierra ¿que pensamientos tengo yo agora? Y la cabeza le respondió, sin mover los labios, con roz claca distinta, de modo que fué de todos entendida esta ra y distinta de modo quesmientos. Oyendo lo qual torazon: yo no juzgo de pensamientos. Oyendo lo qual todos quedáron atónitos, $\mathrm{y}$ mas viendo que en todo el apo sento, ni al derredor de la mesa no habia persona humana que responder pudiese. :Quantos estámos aquí? tornó na que responder pur el pro á preguntar Don Antonio, y fuele repondido por propio tenor, paso : estais tú, y tu muger con dos amigos tuyos y dos amigas della, $y$ un caballero famoso, llamado Don Quixote de la Mancha, y un su cscudero, que Sancho Panza tiene por nombre. Aquí sí que fué el admirarse de nucvo: aquí sí que fué el erizarse los cabellos á todos de puro espanto. Y apartándose Don Antonio de la cabeza dixo: esto me basta para darme á entender, que no fuí en aña del que te me vendió, cabeza sabia, cabeza haengañado del que te me vendio otro, y pregúntele lo que quisiere : y como las mugeres de ordinario son presurosas y amigas de saber, la pri-
PARTIII. CAPÍIUIO IXII $25 \mathrm{I}$ mera que se llegó, fué una de las dos amigas de la muger de Don Antonio, y lo que le preguntó, fué : dime, cabeza ¿que haré yo para ser muy hermosa? y fuéle respondido: sé muy honesta. No te pregunto mas, dixo la preguntanta. Llegó lucgo la compañera, y dixo : querria saber, cabeza, si mi marido me quiere bien, ó no. $Y$ respondiéronlc: mira las obras que te hace, $y$ echar lo has de ver. Apartóse la casada, diciendo: esta respuesta no tenia neccsidad de pregunta, porque cn efecto, las obras que se hacen, declaran la voluntad que tiene cl que las hace. Luego llegó uno de los dos amigos de Don Antonio, y preguntóle ; quien soy yo $\mathrm{Y}$ fućle respondido: tú lo sabes. No te pregunto eso, respondió cl caballe ro, sino que me digas, si me conoces tú? Sí conozco, le respondiéron, que eres Don Pedro Noriz. No quicro saber mas, pues esto basta para entender, ó cabeza, que lo sabes todo. $\mathrm{Y}$ apartándose, llecró el otro amigo y preguntóle: dime, cabeza ¿que descos tiene mi hijo e! mayo razgo? Ya yo he dicho, le respondiéron, que yo no juzgo de deseos; pero con todo cso te sé decir, que los que tu hijo tiene son de enterrarte. Eso es, dixo cl caballero, lo que veo por los ojos, con cl dedo lo seńalo, y no pregunto mas. L.legóse la muger de Don Antonio, y dixo: yo no sé cabeza que preguntarte, solo querria saber de ti, si gozaré muchos años de mi buen marido. Y respondiéronla: sí gozarás, porque su salud y su templanza en el vivir prometen muchos años de vida, la qual muchos suelen acortar por su destemplanza. Llegóse luego Don Quixote, y dixo: dime tú el que respondes $\dot{i}$ fué verdad, ó fué sucino lo que yo cuento que me pasó en la cueva de Montesínos? ¿Serán ciertos los azotes de SanToM. Iv. 
mi escudero? :Tendrá efeto el desencanto de Dulcinea? Á lo de la cueva, respondiéron, hay mucho que decir, de rodo tiene : los azotes de Sancho irán de espacio el desencanto de Dulcinea llegaría á debida exepacio: cl descanto de Dulinca cucion. No quicro sab como yo vea á Dulcinea desencantada, haré cuenta que vienen de golpe todas las venturas que acertare á desear. El último preguntante fué Sancho, y lo que preguntó fé : por ventura, cobezo itendré otro Gobicrno? : saldire de la estrecheza de escu ger y á mis hijos á Á lo que le respondiéron: gobernarás en tu casa, y si vuelves á ella, verís á tu muger y a tus hijos, $y$ dexando de scrvir dexarás de ser escudero. Bueno par Dios, dixo Sancho Panza, esto yo me lo dixera, no dixera mas el Profeta Perogrullo. Bestia, dixo Don Quixotc ; que quicres que te respondan? ¿No basta que las respuestas que esra cabeza ho dado, correspondan á ' S'́ basta respondió Sancho; pero lo que se le pregun quisiera yo que se declarara mas, y me dixera mas. Con esto se acabáron las preguntas y las respuestas; pero no se acabó la admiracion en que todos quedaron, excepto los dos amiros de Don Antonio que el caso sabian EI qual quiso Cide Hamete Benengeli declarar luego por no tener suspenso al mundo, creyendo que algun hechicero, y exrraordinario misterio en la tal cabeza se enccraba: y ái dice que Don Antonio Moreno, á imitacion de y así dice, que Don Antonio Moreno, imicen un estamotra cabeza que vio en Madrid, fabricada por un estampero, hizo esta en su casa, para entretenerse, y suspender á los ignorantes, y la fábrica era de esta suerte. La tabla de la mesa cra de palo, pintada y barnizada como jaspe, y cl pic sobre que se sostenia, era de lo mes-
PARTE II. CAPITULO IXII.

mo, con quatro garras de águila, que dél salian para mayor frmeza del peso. La cabeza, que parecia medalla y figura de Empcrador Romano, y de color de bronce, estaba toda hucca, y ni mas ni ménos la tabla de la mesa cn que se encaxaba tan justamente, que ninguna señal de juntura se parecia. El pie de la tabla era ansimesmo hueco, que respondia á la garganta, y pechos de la cabeza : y todo csto venia á responder á otro aposento, que debaxo de la estancia de la cabeza estaba. Por todo este hucco de pic, mesa, garganta y pechos de la medalla y figura referida se encaminaba un cañon de hoja de lata muy justo, que de nadie podia ser visto. En el aposento de abaxo, correspondiente al de arriba, se ponia el que habia de responder, pegada la boca con el mesmo cañon de modo, que á modo de cerbatana iba la voz de arriba abaxo, y de abaxo arriba en palabras articuladas y claras, $y$ desta manera no cra posible conocer cl embustc. Un sobrino de Don Antonio, cstudiente agudo y discreto, fué el respondiente, el qual estando avisado de suñor tio de los que habian de entrar con él sado de su señor tio de los que habian de en aposento de labeza, le fué fácil responder con presteza y puntualidad á la primera pregunta las demas respondió por conjeturas, $y$ como discreto discretamente. Y dice mas Cide Hancte ", que hasta dicz, ó doce dias duró csta maravillosa máquina; pero que divulgándose por la ciudad que Don Antonio tenia cn su casa una cabeza cncantada, que á quantos le pregun no llecase á los oidos de las despiertas centinclas de nuestra $\mathrm{Fe}$, habiendo declarado cl caso á los señores Inquisidores, le mandáron, que la deshicicse, y no pasase mas adelante, porque el 
254

DO: QUIXOTE DE LA MANCHA

wiro ignorante no se escandalizase. Pero en la opinion de Don Quixote y de Sancho Panza, la cabeza quedó por cncantada y por respondona, mas á satisfacion de Don Quixote, que de Sancho. Los caballeros de la ciudad, por complacer á Don Antonio, y por agasajar á Don Quixote, y dar lugar á que descubriese sus sandeces, orcienáron de correr sortija de allí á seis dias, que no turo efccto, por la ocasion que se dirá adelante. Dióle gana á Don Quixote de pasear la ciudad á la llana, y á pie, temiendo que si iba á caballo, le habian de perseguir los mochachos, y así él y Sancho con otros dos criados que Don Antonio le dió, salićron á pasearse. Sucedio pues, que yendo por una calle, alzó los ojos Don Quixote, $y$ vió escrito sobre una pucrta, con letras muy grandes: Aqui se imprimen libros: de lo que se contentó mucho, porque hasta entónces no habia visto cmprenta alguna, y deseaba saber como fuese. Entro dentro con todo su acompañamiento, y vió tirar en una parte, corregir en otra, componer en esta, enmendar en aquella, y finalmente toda aquella máquina que en las emprentas grandes se muestra. Llegábase Don Quixote á un caxon, y preguntaba, que era aquello que alli se hacia : dábanle cuenta los oficiales, admirábase, y pasaba adclante. Llegó en otras á uno y preguntóle, que cra lo que hacia El oficial le respondió: señor, este caballero que aqui está ( $y$ enseñóle á un hombre de muy buen talle y parecer, $y$ de alguna gravedad) ha traducido un libro toscano cn nuestra Iengua castellana, y estoyle yo componiendo para darle á la estampa. ¿Que título tiene el libro? prepunró Don Quivore. A lo que el autor respondio : señor el libro en toscano se llama Le bagatelle. ¿Y que respon-
PARIEIT. CAPITUIO IXIT. 255 de Le bagatelle en nuestro castellano ? preguntó Don Quixote. Le bagatelle, dixo el autor, es como si en castellano dixésemos los juguetes, $y$ aunque este libro es en el nombre humilde, contiene y encierra en sí cosas muy buenas y substanciales. Yo, dixo Don Quixote, sé algun tanto del toscano, $y$ me precio de cantar algunas estancias del Ariosto. Pero dígame vuesa merced, señor mio (y no digo esto porque quiero exâminar el ingenio de vuesa merced, sino por curiosidad no mas) tha hallado en su escritura alguna vez nombrar pignata? Sí, muchas veces, respondió el autor. ¿Y como la traduce vuesa merced en castellano? preguntó Don Quixore. :Como la habia de traducir, replicó el autor, sino diciendo olla? ¡Cuerpo de tal, dixo Don Quixote, y que adelante está vuesa merced en cl toscano idioma! Yo apostaré una bucna apuesta, que adonde diga en el toscanc piace, dice vuesa merced en el castellano place, $y$ adonde diga piu, dice mas, y el su deciara con arriba, y el giu con abaxo. Sí declaro por cierto, dixo el autor, porque esas son propias correspondencias. Osaré yo jurar, dixo Don Quixote, que no cs vuesa merced conocido en el mundo, enemigo siempre de premiar los floridos ingenios, ni los loables trabajos. $¡$ Que de habilidades hay perdidas por ahí! ;que de ingenios arrinconados! ¡que de virtudes menospreciadas! Pero con todo esto me parece, que el traducir de una lengua en otra, como no sca de las Reynas de las lenguas, gricga y latina, es como quien mira los tapices flamencos por el reves, que aunque se ven las figuras, son llenas de hilos que ias escurecen, y no se ven con la lisura y tez de la haz, y el traducir de lenguas fáciles, ni arguye ingenio, ni elocucion, como 
no le arcuye cl que traslada, ni cl que copia un papel de de orro papel : y iraducir, porque en otras cosas loable este exercicio dul traducir, porque énos prove peores se podria ocupar el hombre, y que ménos provecho le truxesen. Fuera desta cuenta van los dos fa ano el Doctor Christóbal de Figucroa su Pastor Fido, r el otro Don Juan de Xáuregui, en su Pastor Fido, $y$ cl on duda qual en su Aminta, donde felizmente ponen en duda qual es la traducion, ó qual el original. Pero digame vuesa merced este libro imprímese por su cuenta, o tiene ya vendido ol privilegio á algun librero? lor mi cuenta lo vendito el privicgio a algun tibrero? lor mi cuenta imprimo, respondio cl autor, y picnso ganar mil ducados-por lo ménos con esta primera impresion, que ha dos por lo mes cuerpos, y se han de despachar á seis reales les cada uno en daca la pas. Bicn est vuesa marece en la cuenta, respondio Don Quixote: bicn parece que no sabe las entradas y salidas de los impresores, $y$ las correspondencias que hay de unos á otros. Yo le promecorrespondencias que hay de undo de duerpos de to, que quando se vea cargado de dos mil cucrpos de libros, vea tan molido su cuerpo, que se espante, y mas si el libro es un poco avieso, y no nada picante iPues que, divo el autor, quiere vuesa merced que se lo dé á un lidro el aut á quivilc gio tres maravedis, $y$ brero, que me de por dprivilgio térmclos? Yo no aun piensa que me hace merced en dármclos? Yo no imprimo mis libros para alcanzar fama en el mundo, que yo él soy conocido por mis obras : provecho quicro, qa en é so cé que sin el no vale un quatrin la buenaiá vuesa merced buena manderecha, respondió Don Quixote, y pasó adelante á otro caxon, donde vió, que cstaban corrigiendo un pliego de un libro, que se intitulatbo:
PARTE IT. CAPITULO IXIT.

bros, aunque hay muchos deste género, son los que se deben imprimir, porque son muchos los pecadores que se usan, y son menester infinitas luces para tantos desalumbrados. Pasó adclante, y vió que asimesmo estaban corrigiendo otro libro, y preguntando su título, le respondiéron, que se llamaba: La segunda parte del ingenioso $\mathrm{H}_{\text {i- }}$ dalgo Don Ouixote de la Mancha, compuesta por un tal, vecino de Tordeśllas. Ya yo tengo noticia deste libro, dixo Don Quixote, y en verdad y en mi conciencia, que pensé que ya estaba quemado y hecho polvos por impertinente; pero su San Martin se le llegará, como á cada puerco: que las historias fingidas tanto tienen de buenas $y$ de deleytables, quanto se llegan á la verdad, ó á la semejanza della, y las verdaderas tanto son mejores, quanto son mas verdaderas: $y$ diciendo esto, con muestras de algun despecho se salió de la emprenta, y aquel mesmo dia ordenó Don Antonio de llevarle á ver las galeras, que en la playa estaban, de que Sancho se regocijó mucho, á causa que en su vida las habia visto. Avisó Don Antonio al Quatralvo de las galeras, como aquella tarde habia de llevar á verlas á su huésped el fimoso Don Quixote de la Mancha, de quien ya el Quatralvo y todos los vecinos de la ciudad tenian noticia, y lo que Ic sucedió en cllas, se dirá en el siguiente capítulo.

\section{CAPITTULO LXIII.}

De lo mal que le avino á Sancho Panza con la visita de las galeras, y la nueva aventura de la hermosa Morisca.

Grandes eran los discursos que Don Quixote hacia soTos. Iv. 
bre la respuesta de la encantada cabeza, sin que ningunollos dicse en el embuste, y todos paraban con la promesa, que él tuvo por cierto, del desencanto de Dulcinea. Allí iba, y venia, y se alegraba entre sí mismo, creyendo que habia de ver presto su cumplimiento, y Sanho anque aborrecia el ser Gobernador , como queda cho, aunque abor Jenta cido: que esta mala ventura trae consigo el mando, aunque sca de burlas. En resolucion, aquella tarde Don Antonio Moreno su huésped y sus dos amigos, con Don Quitonio Moreno su huéped ý sus dos amigo xote y Sancho, fueron a las galcras. El Quatralvo que estaba avisado de su buena venida, por ver á los dos tan famosos Quixote y Sancho, apénas llcgáron á la marina, guando todus las galcras abatiéron tienda, $y$ sonáron las chirimís : arrojín luego el csquife al agua cubierto de ricos tapetes y de almohadas de terciopelo carmesí, y en poniendo que puso los pies en él Don Quixote, disparó la Capitana el cañon de cruxía, y las otras galeras hiciéron lo mesmo, y al subir Don Quixote por la escala derecha, toda la chusma le saludó, como cs usanza, quando una persona principal entra en la galera, diciendo: hu, hu, hu, tres veces. Dióle la mano el General, que con ere un principal cacollcro Valenciano : abrazó a Don Quixore diciéndole ballero Valenciano: ab cste dia señalaré yo con piedra blanca, por scr uno de los mejores que pienso llevar en mi vida, habiendo visto al senor Don Quixote de la Mancha: tiempo y seña que nos muestra, que en él se encierra y cifra todo el valor de la andante caballería. Con otras no ménos corteses razones le respondió Don Quixote, alegre sobremanera de verse tratar tan á lo Señor. Entríron todos en popa, que cstaba muy bien aderezada, y scntáronse por los bandines: pasóse el Cómitre en cruxía, y dió señal con el pito que la chusma hiciese fueraropa, que se hizo en un instante. Sancho, que vió tanta gente en cueros quedó pasmado, y mas quando vió hacer tienda con tanta priesa, que á él le pareció que todos los diablos andaban allí trabajando; pero esto todo fuéron tortas y pan pintado para lo que ahora diré. Estaba Sancho sentado sobre el estanterol junto al espalder ${ }^{\text {st }}$ de la mano derecha, el qual ya avisado de lo que habia de hacer, asió de Sancho, y levantándole en los brazos, toda la chusma puesta en pie y alerta, comenzando de la derecha banda, le fué dando y volteando sobre los brazos de la chusma de banco en banco, con tanta priesa, que el pobre Sancho perdió la vista de los ojos, $y$ sin duda pensó, que los mismos demonios le llevaban, y no paríron con él, hasta volverle por la siniestra banda, y poncrle en la popa. Quedó cl pobre molido y jadcando y trasudando, sin poder imaginar que fué lo que sucedido le habia. Don Quixote que vió cl vuelo sin alas de Sancho, preguntó al General, si cran cercmonias aquellas que se usaban con los primeros que entraban en las galeras, porque si acaso lo fucse, él, que no tenia intencion de profesar en ellas, no queria hacer semejantes excrcicios, y que votaba á Dios, que si alguno llegaba á asirle para voltearle, que le habia de sacar el alma á puntillazos: y diciendo esto, se levantó en pie y cmpunó la espada. Á este instante abatiéron tienda, y con grandísimo ruido dexáron caer la entena de alto abaxo. Pensó Sancho, que el cielo se desencaxaba de sus quicios, y veniná Jar sobre su cabeza, y agoviándola lle no de miedo, la puso entre las piernas. No las tuvo toIOM. IN. . 
260

DON QUTXOTE DE LA MANCHA

das consigo Don Quixote, que tambicn se estremeció, encogió de hombros, y perdió la color del rostro. La y encogio de hombros, y percís la color del rosto La collo si no tuvieran voz ni aliento. Hizo señal cl Cómitre que zarpavicran voz, y saltando en mitad de la cruxía con cl corsen cl fero, y salando en mís mosquear las espaldas de vacho, o rebenque, comenzo á mosquear las espaldas de la chusma y á largarse poco a poco a la mar. Quando Sancho vióá una moverse tantos pics colorados (que tales pensó cue cran los remos) dixo entre sí : cstas sí son penso due cran lo dice. ¿Que han hecho estos desdichados, que ansi los azotan? ¿y como este hombre solo, que anda por aquí silvando tiene atrevimiento para azotar á tanta gente : Ahora , ó por lo ménos el purgatoyo digo que este es infer rio. Don Quixote que raba lo que pasaba, le dixo: $j$ ah Sancho amigo, $y$ con que brevedad, y quan á poca costa os pocíades ros, si quisiés des, denudar de medio cuerpo arriba, y poncCestos señres, y acabar con el descncanto de Dulcinea! pues con la miseria y penia de tantos no sentiríades vos mucho la vuestra: y mas, que podria ser, que el sabio Merlin tomase en cuenta cada azote destos, que el sabio Mer lin te los que vos finalmente os habeis de dar. Preguntar queria el General que azotes eran aquellos, ó que desencanto de Dulcinea, quando dixo el marinero: señal hace Monjuich de que hay baxel de remos en la costa por la banda del poque hay baxa de remos niente. Esto oido, salto el General en la cruxta, y dixo: ea hijos, no se nos vaya : algun bergatin de cosarios de Argel debe de ser este, que la atalaya nos señala. Lle-
PARTE IT. CAPITULO LXII.

gúronse luego las otras tres galeras á la Capitana á saher lo que se les ordenaba. Mandó el General, que las dos saliesen á la marr y él con la otra iria tierra á tierra, porque ansí el baxcl no se les escaparia. Apretó la chusma los remos, impeliendo las galeras con tanta furia, que parecia que volaban. Las que saliéron á la mar á obra de dos millas descubrićron un baxel, que con la vista le marcáron por de hasta catorce, o quince bancos, y así cra la verdad, el qual baxel, quando descubrió las galcras, se puso en caza, con intencion y csperanza de escaparse por su ligereza; pero avínole mal, porque la galera Capitana cra de los mas ligeros baseles que en la mar navegaban, y así le fué entrando, que claramente Jos del berrantin conociéron que no podian escaparse, y así el Arricz quisiera que dexaran los remos, y se entregaran, por no irritar á enojo al Capitan que nuestras galeras regia; pero la sucrte, que de otra manera lo guiaba, ordenó que ya que la Capitana llegaba tan cerca, que podian los del baxel oir las roces que desde ella les decian, que se rindiesen, dos Toraquis, que es como decir, dos Turcos borrachos, que en el bergantin venian con otros doce, disparáron dos escopetas, con que diéron mucrte a dos soldados, que sobre nucstras arrumbadas venian. Viendo lo qual, juró el Gencral de no dexar con vida á todos quantos $\mathrm{cn} \mathrm{cl}$ baxel tomase, y llegando ́s embestir con toda furia, se le escapó por debaxo de la palament2. Pasó la gralera adclante un buen trecho: los del baxel se viéron perdidos: hiciéron vela en tanto que la galera volvia, y de nuevo á vela y á remo se pusiéron en caza ; pero no les aprovechó su diligencia, tanto como les dańo su atrevimiento, porque alcanzándoles la Capitana 
DON QUTXOTE DE LA MANCIA

á poco mas de media milla , les cchó la palamenta cncima y los cogió vivos á rodos. Llegáron cn esto las otras dos galeras, y todas quatro con la presa volviéron á la pla ga donde infita gente los cstaba esperando descoplaya, donde infinita gente los estaba esperando, descosos de ver lo que traian. Dió fondo el General cerca de tierra, y conoció, que estaba en la marina el Virey de la ciudad. Mandó cchar el esquife para tracrle, y mandó amaynar la entena, para ahorcar luego luego al Arráez, y á los demas Turcos, que en el baxel habia cogido, que serian hasta treinta y seis personas, todos gallardos, y los mas escopeteros Turcos. Preguntó el General quicn era el Arrá del bergantin, y fućle respondido por uno de los cautivos en lengua castellana (que despucs pareció ser renegado Español) este mancebo, señor, que aquí ves, es nuestro Arrácz, y mostróle uno de los mas billos y gallardos mozos que pudiera pintar la humana imaginacion. La edad, al parecer, no llegaba á veinte años. Preguntóle el General : dime, mal aconsejado perro ¿quien te movió á matarme mis soldados, pues veias ser imposible el escaparte? ¿Este respeto se guarda á las Capitanas? No sabes tú que no es valentía la temeridad? Las esperanzas dudosas han de hacer á los hombres atrcvitos, pero no temerarios. Responder queria el Arráez, pero no pudo el Gencral por cntonees oir la respuesta, por acudir á reccbir al Virey, que ya entraba en la galera, con el qual entráron algunos de sus criados y algunas personas del pueblo. Buena ha cstado la caza, señor Gencral, dixo el Vircy. Y tan buena, respondió el Gencral qual la verá Vuestro Excelencia agopondio el Gencral, qual la vera Vuestra Excelcncia agora colgada de esta entena. ¿ Porque me han mucrto, respondió el General, con-
PARTEII. CARITUIO IXIII.

tra toda ley y contra toda razon y usanza de gucra, dos soldados de los mejores que en estas galeras venian, y yo he jurado de ahorcar á quantos he cautivado, principalmente á este mozo, que es el Arrácz del bergantin, y enseñóle al que ya tenia atadas las manos, y echado el cordel á la garganta, espcrando la mucrte. Miróle el Virey, $\mathrm{y}$ viéndole tan hermoso $\mathrm{y}$ tan gallardo y tan humilde, dándole en aquel instante una carta de recomendacion su hermosura, le vino deseo de excusar su muerte, y así le preguntó : dime Arráez jeres Turco de nacion, ó Moro, ó renegado? Á lo qual el mozo respondió, en lengua asimesmo castellana : ni soy Turco de nacion, ni Moro ni renerado. : Pues que eres? replicó el Virey. Muger christiana, respondió el mancebo. ¿Muger christiana, $y$ en tal trage, y en tales pasos? mas es cosa para admirarla que para creerla. Suspended, dixo el mozo, ó seńores, la execucion de mi muerte, que no se perderá mucho en que se dilate vuestra venganza en tanto que yo os cuente mi vida. Q Quien fuera el de corazon tan duro, que con estas razones no se ablandara, ó aloménos ${ }^{32}$ hasta oir las que el triste y lastimado mancebo decir queria? El General le dixo, que dixese lo que quisicse; pero que no esperase alcanzar perdon de su conocida culpa. Con esta licencia , cl mozo comenzó a decir desta mancra: de aquella nacion mas desdichada, que prudente, sobre quicn ha llovido cstos dias un mar de desgracias, nací yo de Moriscos padres engendrada. En la corriente de su desventura fuí yo por dos tios mios llevada á Berbcría, sin que me aprovechase decir ouc ara Christiana, como cn efecto lo soy, $y$ no de las fingidas, ni aparentes, sino de las verdaderas 
264

DON QUIXOTE DE IA MANCHA

y católicas. No me valió con los que tenian á cargo nuestro miserable destierro decir esta verdad, ni mis tios quisiéron creerla, ántes la tuviéron por mentira, y por invencion para quedarme en la tierra donde habia nacido, y así por fuerza mas que por grado, me truxéron consigo. Tuve una madre Christiana, y un padre discreto y Christiano, ni mas, ni ménos : mamé la fe católica en la leche, criéme con buenas costumbres : ni en la lengua ni en ellas jamas, á mi parecer, dí señales de ser $\mathrm{Mo}$ risca. Al par, y al paso destas virtudes, que yo crco que lo son, creció mi hermosura, si es que tengo alguna, $y$ aunque mi recato $\mathrm{y} \mathrm{mi}$ cncerramiento fué mucho, no debió de ser tanto, que no tuviese lugar de verme un mancebo caballero, llamado Don Gaspar Gregorio, hijo mayorazgo de un caballero, que junto á nuestro $\mathrm{Lu}$ gar otro suyo tiene. Como me vió , como nos hablamos, como se vió perdido por mí, y como yo no nuy gana da por él, seria largo de contar, y mas en tiempo que estoy temiendo, que entre la lengua y la garganta se ha de atravesar el riguroso cordel, que me amenaza, $y$ as solo diré como en nuestro destierro quiso acompañarme Don Gregorio. Mezclóse con los Moriscos que de otros Lugares salićron, porque sabia muy bien la lengua, $y$ en el viage se hizo amigo de dos tios mios, que consigo me traian, porque mi padre prudente y prevenido, así cono oyó el primer bando de nuestro destierro se salió del Lugar, y se fué á buscar alguno en los Reynos extraños, que nos acogiese. Dexó encerradas y enterradas en una parte, de quien yo sola tengo noticia, muchas perlas y piedras de gran valor, con algunos dineros en cruzados $y$ doblones de oro. Mandóme que no tocase al tesoro que
PARTEII. CAPfTUIO IXIIT. $26_{5}$ dexaba en ninguna mancra, si acaso ántes que él volviese nos destcrraban. Hícelo así, y con mis tios, como tengo dicho, $y$ otros parientes y allegados pasamos á Berbería, y el Lugar donde hicimos asiento, fué en Argel, como si le hiciéramos en el mismo infierno. Turo noticia el Rey de mi hermosura, y la fama se la dió de mis riquezas, que en partc fué ventura mia. Llamóme ante sí, preguntóme de que parte de España cra, y que dineros y que joyas traia. Díxele el Lugar, y que las joyas y dineros quedaban en él enterrados; pero que con facilidad se podrian cobrar si yo misma volvicse por ellos. Todo esto le dixe temerosa de que no le cegase mi hermosura, sino su codicia. Estan do conmigo en estas pláticas, le llegáron á decir, como venia conmigo uno de los mas gallardos y hermosos manccbos que se podia imaginar. Luego entendí, que lo decian por Don Gaspar Gregorio, cuya belleza se dexa atras las mayores que cncarecerse pucden. Turbéne, considerando el peligro que Don Gregorio corria, porque entre aquellos bárbaros Turcos, en mas se tiene y estima un mochacho, ó mancebo hermoso, que una muger, por bellisíma que sea. Mandó luego el Rey, que se le truxesen allí delante para verle, y preguntóme, si cra verdad lo que de aquel mozo le decian. Entónces yo, casi como prevenida del Ciclo le dise, que sí cra; pero que le hacia saber, que no era varon, sino muger como yo, y que le suplicaba me la dexase ir á vestir en su natural trage, para que de todo en todo mostrase su belleza, y con ménos empacho pareciese ante su presencia. Díxome, que fuese en buena hora, y que orro dia hablaríamos en el modo que se podia tener para que yo volviese á España á sacar cl escondido tesoro. Hablé con Don Gaspar, contéle el peligro Tom. Ir. 
que corria el mostrar ser hombre: vestile de Mora, y aquella mesma tarde le truxe á la presencia del Rey, el qual en viéndole, quedó admirado y hizo designio de guardarla para hacer presente della al Gran Señor, y por huir del peligro que en el serrallo de sus mugeres podia tener y temer de sí mismo, la mandó poner en casa de unas principales Moras, que la guardasen y la sirviesen, adonprinciplé ) se dexe á la consideracion puedo negar que le quiero) se dexe á la consideracion de los que se apartan, si bien se quiercn. Dió luego tra2 el Rey de que yo volviese á España en este bergantin, 2a y que me acompanasen dos Turcos de nacion, que fueron los que mars conmigo cste renegado Español, señalando al que habia hablado primero, del qual sé yo bien que es Christiano encubiero, y que viene con mas deseo de quedarse en España, que de volver á Berbería : la demas chusma de bergantin son Moros y Turcos, que no sirven de mas, que de bogar al remo. Los dos Turcos codiciosos, é insolentes, sin guardar el órcien que traíamos, de que á mí y á este renegado en la primer parte de España, en hábito de christianos, de que venimos proveidos, nos echasen en tierra, primero quisićron barrer esta costa, y hacer alguna presa si pudiesen, temiendo que si primero nos echaban en tierra, por algun accidente que á los dos nos sucediese, podríamos descubrir que quedaba el bergantin en la mar, y si acaso hubiese galeras por esta costa, los tomesen. Anoche descubrímos est2 playa, y sin tener noticia destas quatro galeras, fuímos descubiertos, $y$ nos ha sucedido lo que habeis visto. En resolucion, Don Gregorio queda en hábito de muger entre mugeres, con manifiesto peligro de perderse, y yo me veo atadas las manos, esperando , o por mejor decir, temiendo perder la vida que ya me cansa. Este es, señores, el fin de mi lamentable historia, tan verdadera, como desdichada: lo que os ruego es, que me dexeis morir como christiana, pues, como ya he dicho, en ninguna cosa he sido culpante de Ia culpa en que los de mi nacion han caido: y luego calló, preñados los ojos de tiernas lágrimas, á quien acompańrion muchos de los que presentes estaban. El Virey, tierno y compasivo, sin hablarle palabra se llegó á ella, y le quitó con sus manos el cordel, que las hermosas de la Mora ligaba. En tanto pues que la Morisca Christiana su peregrina historia trataba, tuvo clavados los ojos en ella un anciano peregrino, que entró en la galera, quando entró el Virey, y apénas dió fin á su plática la Morisca, quando él se arrojó á sus pies, y abrazado dellos, con interrumpilas palabras de mil sollozos y suspiros, le dixo: ó Ana Félix, desdichada hija mia, yo soy tu padre Ricote, que volvia á buscarte, por no poder vivir sin ti, que cres mi alma. A cuyas palabras abrió los ojos Sancho, y alzó la cabeza, que inclinada tenia, pensando en la desgracia de su paseo, y mirando al peregrino conoció ser el mismo Ricore, que topó el dia que salió de su Gobierno y confirmóse que aquella cra su hija, la qual ya desatada abrazó á su padre, mezclando sus lágrimas con las suyas : el qual dixo al General y al Virey : esta, scñores, es mi hija, mas desdichada en sus sucesos que cn su nombre. Ana Félix se llame con el sobrenombre de Ricote, famosa tanto por su hermosura, como por mi riqueza : yo salí de mi patria á buscar en Reynos extraños quien nos albergase y recogiese, y haTor. iv. 
biéndole hallado en Alemania, volví en este hábito de peregrino, en compañía de otros Alemanes á buscar mi hija, y á desenterrar muchas riquezas que dexé escondidas. No hallé á mi hija, hallé el tesoro que conmigo traigo, y ago ra por el extraño rodeo que habcis visto, he hallado el tesoro que mas me enriquece, que es á mi qucricia hija: si nuestra poca culpo y sus ligrimas y las mias por la inrcerridad de vuestra justicia pueden abrir puertas á la miscricordia, usadla con nosotros, que jamas tuvímos pensamien to de ofenderos ni convenímos en ningun modo con an sito destcrrados. Entónces dixo Sancho : bien conozco á Ricore y sé que es verdad lo que dice en quanto á ser Ana Félix su hija, que en esotras zarandajas de ir y venir, tener buená mala intencion, no me entremeto. Admirados del extraño caso todos los presentes, el Genera dixo: una por una vuestras lágrimas no me dexarán cumpir mi juramento : vivid, hermosa Ana Fílix, los años de vida que os tiene determinado el Cielo, y lleven la pena de su culpa los insolentes y atrevidos que la cometiéron, y mandó luego ahorcar de la entena á los dos Tutcos que á sus dos soldados habian muerto; pero el Virey le pidió encarecidamente no los ahorcase, pues mas locura, que valentía habia sido la suya. Hizo el Gencril lo que $\mathrm{cl}$ Vircy le pedia, porque no se executan bien las venganzas á sancre helada. Procuráron luego dar traza de sacar á Don Gaspar Gregorio del peligro en que quedaba. Ofreció Ricote para ello mas de dos mil ducados, que en perlas y en joyas tenia. Dićronse muchos medios; pero ninguno fue thl como el que dió el renegado Español, que se ha dicho, el qual se ofreció de volver á Argel en algun barco pequeño, de hasta seis bancos, armado de remeros christianos, porque él sabia donde, como y quando podia y debia desembarcar : y asimismo no ignoraba la casa donde Don Gaspar quedaba. Dudáron cl General y cl Vircy el fiarse del renegado, ni confiar dél los cliristianos que habian de bogar el remo. Fióle Ana Félix, y Ricote su padre dixo, que salia á dar el rescate de los christianos, si acaso se perdiesen. Firmados pues en este parccer, se desembarcó cl Vircy, y Don Antonio Moreno se llevó consigo á la Morisca, y á su padre, encargándole el Vircy que los regulase y acariciase quanto le fucse posible, que de su parte le oftecia lo que en su casa hubiese para su regalo. Tanta fué la benevolen cia y caridad que la hermosura de Ana Félix infundió en su pecho.

\section{CAIITULO LXIV.}

Que trata de la aventura que mas pesadumber dió a Don Quixote de quantas hasta entónces le habian

La muger de Don Antonio Moreno, cuenta la historia, que recibió grandísimo contento de ver á Ana Félix en su casa. Recibióla con mucho agrado, así enamorada de su belleza, como de su discrecion, porque en lo uno y en lo otro cra extremada la Morisca, y toda la gente de la ciudad, como á campana tañida, venian á verla. Dixo Don Quixote á Don Antonio, que el parecer que habian tomado en la libertad de Don Gregorio, no cra bueno, porque tenia mas de peligroso que de conveniente, y que seria mejor que le pusiesen á él en Berbería con sus armas y caballo que ćl le sacaria á pesar de toda la Morisma, co- 
mo hia hecho Don Gayferos is su esposa Mclisendra. Advierta vuesa merced, dixo Sancho, oyendo esto, que el señor Don Gayféros sacó á su esposa de tierra firme y la llevó á Francia por tierra firme; pero aquí, si acaso sacamos á Don Gregorio, no tenemos por donde tracrló Espana pues está Ia mar en medio. Para todo hay remedio, sino es para la muerte, respondio Don Quixote, pues llegando cl barco á la marina, nos podrémos embar en él, aunque todo el mundo lo impida. Muy bien lo pinta $y$ facilita vuesa merced, dixo Suncho; pero del dicho al hecho hay gran trecho, y yo me atengo al renegado, que me parce muy hombre de bien y de muy buenas entrañas. Don Antonio dixo que si el renegado no saliese bien del caso, se tomaria cl cxpedicnte de que el gran Don Quixote pasase en Berbería. De allí á dos dias partió el renegado en un ligero barco de seis remos por banda, armado de valentísima chusma, y de allía otros dos se partićron las galeras á Lcvante, habiendo pedido el General al Visorey fucse servido de avisarle de lo que sucediese en la libertad de Don Grego rio y en cl caso de Ana Félix. Quedó cl Visorey de hacerlo así como se lo pedia: y una mañana, saliendo Don Quixote á pasearse por la playa, armado de todas sus armas, porque, como muchas veecs decia, cllas cran sus arreos, y su descanso el pelear, y no se hallaba sin ellas un punto, vió venir hácia él un caballcro armado asi mismo de punta en blanco, que en cl escudo traia pintada una luna resplandeciente, el qual llegándose á trecho que podia ser oido, en altas voces, encaminando sus razones á Don Quixote, dixo : insigne Caballero, y jamas, como se debe, alabado Don Quixote de la Mancha, yo soy el caballero de la Blanca Lana, cuyas inauditas hazañas quizá te le habrán traido á la memoria: vengo á contender contigo, y á probar la fuerza de tus brazos, en razon de hacerte conocer y confesar, que mi dama sea quien fucre, es sin comparacion mas hermosa que tu Dulcinea del Toboso, la qual verdad si tú la confiesas de llano en llano, excusarás tu muerte, y el trabajo que yo he de tomar en dártela, y si tú pcleares, y yo te venciere, no quiero otra satisfacion, sino que dexando las armas, y abstcniéndote de buscar aventuras, te recojas y retires á tu Lugar por tiempo de un año, donde has de vivir sin echar mano á la espada, en paz tranquila y en provechoso sosiego, porque así conviene al aumento de tu hacienda y á la salvacion de tu alma: y si tú me vencieres, quedará á tu discrecion mi cabeza, y serán tuyos los depojos de mis armas y caballo, y pasarí í la tuya la fama de mis hazañas. Mira lo que te está mejor, y respóndeme luego, porque hoy todo el dia traigo de término para despachar este negocio. Don Quixote quedó suspenso y atonito, asi de la arrogancia del coballero de la Blanca Luna, como de la causa por que le desafiaba, y con reposo y adcman severo le respondió : caballero de la Blanca Luna, cuyas hazañas hasta ahora no han llegado á mi noticia, yo os haré jurar, que jamas habcis visto á la ilustre Dulcinea, que si visto la hubiérades, yo sé que procurárades no poneros en esta demanda, porque su vista os desengañara, de que no ha habido, ni puede haber belleza que con la suya compararse pueda: y así no diciéndoos que mentis, sino que no accrtais an lo propuesto, con las condiciones que habeis referido aceto vuestro desafio, y luego, porque no se pase el dia que 
$27^{2}$

DON QUIXOTE DE LA MANCHA

treis determinado, y solo exceto de las condiciones, la de que se pase á mí la fama de vuestras hazañas, porque no sé quales, ni que tales sean : con las mias me contento tales quales ellas son. Tomad pues la parte del campo que quisiéredes, que yo haré lo mesmo, y á quien po que quisieredes que yo ha la bendiga Habian descubierto de la ciudad al caballero de la Blanca Luna, y díchoselo al Visorey, que estaba hablando con Don Quixote de la Mancha. El Visorey creycndo seria alguna nuete ave la Moricade por Don Antonio Moreno, ó por otro algun caballero de la ciudad con Don Antonio y con otros muchos caballeros, que le acompañaban, á tiempo quando Don Quixote volvia las ré 1. Viendo pues a Visorey que daban los dos señales de volverse á encontrar, se puso en medio, preguntándoles, que era la causa, que les movia á hacer tan de im proviso batalla. El cabaliero de la Blanca Luna respondió, proviso bath El cable cia de hermosura, y cn breves razones le dixo las mismas que habia dicho a Don Quixote, con la acetacion de las condiciones del desafio, hechas por en trámbas partes. Llegóse el Visorey á Don Antonio, y tramas partes caballero de la preguntole paso, sl sabia quien era cl cal ciballero de Blanca Luna, ó si era alguna burta qu Don Quixote. Don Antonio le respondió, que ni sabia quien era, ni si era de burlas, ni de véras el tal desafío. Esta respuesta tuvo perplexo al Visorey, en si les dexaria, o persuadir á que fuese sino burla, se apartó, diciendo: persuadir a que fuese sino burla, se apartó, dino confesar ó morir, y el señor Don Quixote está en sus trece y

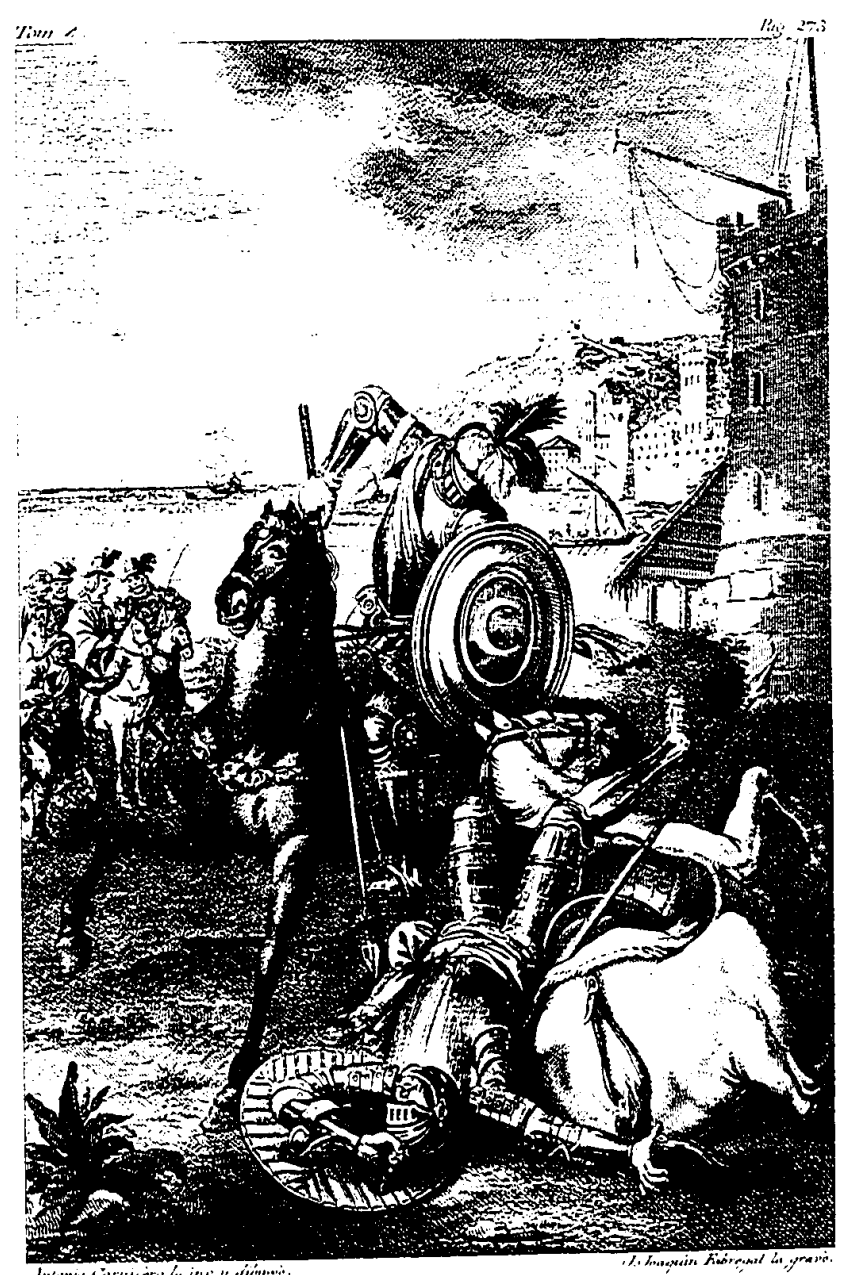


vuesa merced el de la Blanca Luna en sus catorce, á la mano de Dios y dense. Agradeció el de la Blanca Luna con corteses y discretas razones al Visorey la licencia que se les daba, y Don Quixote hizo lo mesmo, el qual encomendíndose al Ciclo de todo corazon, y á su Dulcinea, como tenia de costumbre, al comenzar de las batallas que se le ofrecian, tornó á tomar otro poco mas del campo, porque vió que su contrario hacia lo mesmo, y sin rocar trompeta, ni otro instrumento bélico, que les diese señal de arremeter, volviéron entrámbos á un mesmo punto las riendas á sus caballos, y como cra mas ligero el de la Blanca Luna, llegó á Don Quixote á dos tercios andaclos de la carrera, $\mathrm{y}$ allí le encontró con tan poderosa fuerza, sin tocarle con la lanza, que la levantó, al parecer, de propósito, que dió con Rocinante y con Don Quixote por el suclo una peligrosa caida. Fué luego sobre ćl y poniéndole la lanza sobre la visera, le dixo: vencido sois, caballero, $y$ aun mucro, si no confesais las condiciones de nucstro desafío. Don Quixote molicio y aturdido, sin alzarse la visera, como si hablara dentro de una tumba, con roz debilitada y enferma, dixo: Dulcinea del Toboso es la mas hermosa muger del mundo, $y$ yo el mas desdichado caballcro de la tierra, y no es bien que mi flaqueza defraude csta verdad : apricta, caballero, la lanza, y quítame la vida, pues me has quitado la honra. Eso no haré yo por cicro dixo el de la Blanca Luna : viva, viva en su entereza la fama de la hermosura de la Señora Dulcinca del Toboso, que solo me contento con que el gran Don Quixote se retire á su Lugar un año, ó hasta el riempo que por mí le fiere mandado, como concertámos ántes de entrar en esta baralla. Todo esTox. Iv. 
274

DON QUIXOTE DE IA MANCIIA

to oyéron el Visorey y Don Antonio, con otros muchos que allí estaban, y oyćron asimismo que Don Quixote respondió, que como no le pidiese cosa que fuese en te re lo demas cumpliria, como perjuticio de Dulcinea, to do demas cumpling caballero puntual y verdadero. Hecha esta confesion, volvió las riendas el de la Blanca Luna, y haciendo mesura con la cabeza al Visorey, á medio galope se cntró en la ciudad Mandó el Visorey á Don Antonio, que fuese clucad. Mando el Visorcy a Don Antonio tras él , y que en todas mancras supiese quien cra. Levantáron á Don Quixote, descubriéronle el rostro, y hallit ronle sin color y trasudando. Rocinante de puro mal parado no se pudo mover por entónces. Sancho, todo triste do no se pudo mover por chtonces Sancho to no todo apesarado, no sabia que decirse, ni que hacerse. Pa recíale que todo aquel suceso pasaba en sucíios, y que toda aquella máquina era cosa de encantamento. Veia á su ser rendido $y$ obligado á no tomar armas en un año. Imaginaba la luz de la gloria de sus hazañas escureci $\mathrm{da}$, las esperanzas de sus nuevas promesas deshechas, $\mathrm{co}$ mo se deshace el humo con el viento. Temia si quedaria, ó no contrecho Rocinante, ó deslocado su amo: que no fuera poca ventura, si deslocado quedara. Finalmente con una silla de manos, que mandó tracr cl Visorey, le lleváron á la ciudad, y el Visorey se volvió tambien á clla con deseo de saber quien fuese el caballero de la Blanca Luna, que de tan mal talante habia dexado á Don Quixote.

\section{CAPITTULO LXV.}

Donde se da noticia quien era el de la Blanca Luna, con la libertad de Don Gregorio, y de otros sucesos.

Siguió Don Antonio Moreno al caballero de la Blan-
PARTEII. CAPÍTULO IXV.

ca ILuna, $y$ siguićronle tambien, $y$ aun persiguiéronle muchos muchachos, hasta que le cerráron en un meson dentro de la ciulad. Entró en él Don Antonio con desco de conocerle: salió un escudero á recebirle y á desarmarle: enccróse en una sala baxa, y con él Don Antonio, que no se le cocia el pan hasta saber quien fuese. Viendo pues el de la Bianca Luna, que aquel caballero no le dexaba, le dixo: bien sé, señor á lo que venis, que es á saber quien soy, y porque no hay para que negároslo, en tanto que este ni criado me desarma, os lo diré, sin faltar un punto á la verdad del caso. Sabed, scñor, que á mí me llaman el Bachiller Sanson Carrasco. Soy del mesmo Lugar de Don Quixore de la Mancha, cuya locura y sandez mueve á que le tengamos lástima todos quantos le conocemos, $y$ entre los que mas se la han tenicto he sido yo, $y$ creyendo que está su salud en su reposo, $y$ en que se esté en su tierra y en su casa, di traza para hacerle estar cn clla, y así habrá tres meses que le salí al camino como cuballero andante, llamíndome cl caballero de los Espejos, con intencion de pelear con él y venecrle, sin hacerle daño, poniendo por condicion de nuestra pelea, que rencico quedase á discrecion del vencedor: $y$ lo que yo pensba pedirlo, porque ya le juzabu por ven que yo pensaba pedirle, porque ya le juzgaba por vencido, cra que se volviese á su Lugar, y que no saliese dél cn todo un año, en el qual tiempo podria ser curado; pero la suerte lo ordenó de otra manera, porque él me pero la ' y me derribó del caballo, y así no tuvo efceto mi pensamicnto : él prosiguió su camino, y yo me volví vencido, corrido y molido de la caida, que fué ademas peligrosa; pero no por esto se me quiró cl deseo de vor á busarle y á vencerle, como hoy se 12 visto. de volver á buscarle y á vencerle, como hoy том. iv. 
276

DON QUIXOTE DE LA MANCHA

$\mathrm{Y}$ como él es tan puntual en guardar las órdenes de la andante caballería, sin duda alguna guardará la que le he dado en cumplimiento de su palabra. Esto es, señor, lo que pasa, sin que tenga que deciros otra cosa alguna : suplícoos no me descubrais, ni le digais á Don Quixote quien soy ${ }^{33}$, porque tengan efecto los buenos pensamientos mios, y vuelva á cobrar su juicio un hombre que le ticne bońsimo como le dexen las sandeces de la caballería. ¡O señor! dixo Don Antonio, Dios os perdone el agravio que habeis hecho á todo el mundo, en querer volver cuerdo al mas gracioso loco que hay en él. ¿No veis, señor, que no podrá llegar el provecho que cause la cordura de Don Quixote, á lo que llega cl gusto que $\mathrm{da}$ con sus desvaríos? Pcro yo imagino que toda la industria del señor Bachiller no ha de ser parte para volver cuerdo á un hombre tan rematadamente loco, y si no fuese contra caridad, diria, que nunca sane Don Quixote, porque con su salud, no solamente perdemos sus gracias, sino las de Sancho Panza su escudero, que qualquicra dellas puede volver á alegrar á la misma melancolía. Con todo esto callaré, y no le diré nada, por ver si salgo verdadero en sospechar que no ha de tener efecto la diligencia hecha por el señor Carrasco. El qual respondió, que ya una por una estaba en buen punto aque negocio, de quien esperaba feliz suceso, $y$ habiéndose ofrecido Don Antonio de hacer lo que mas le mandase, se despidió dél, y hecho liar sus armas sobre un macho, Iuego al mismo punto sobre el caballo con que entró en la batalla, se salió de la ciudad aquel mismo dia, y se volvió á su patria, sin sucederle cosa que obligue á contarla en esta verdadcra historia. Contó Don Antonio al
PARTE II. CAYITUIO LXV.

Visorey todo lo que Carrasco le habia contado, de lo que el $\mathrm{V}$ isorcy no recibió mucho gusto, porque en el recogimiento de Don Quixote se perdia el que podian tener rodos aquellos que de sus locuras tuviesen noticia. Seis dias estuvo Don Quixote en el lecho, marrico, triste, pensativo y mal acondicionado, yendo y viniendo con la imaginacion en el desdichado suceso de su vencimiento. Consolábale Sancho, y entre otras razones le dixo: señor mio, alce vuesa merced la cabeza, y alégrese si puede, y dé gracias al Ciclo, que ya que le derribó en la tierra, no salió con alguna costilla quebrada, y pues sabe que donde las dan las toman, y que no siempre hay tocinos donde hay cstacas, dé una higa al médico, pues no le ha menester para que le cure en esta enfermedad. Volvámonos á nuestra casa, y dexémonos de andar buscando aventuras por tierras y lugares que no sabemos, $y$ si bien se considera, yo soy aquí el mas perdidoso, aunque es vuesa merced el mas mal parado. Yo que dexé con el Gobierno los deseos de ser mas Gobernador, no dexé la gana de ser Conde, que jamas tendrá efecto, si vuesa merced dexa de ser Rey, dexando el exercicio de su caballería, y así vienen á volverse en humo mis esperanzas. Calla, Sancho, pues ves que mi reclusion y retirada no ha de pasar de un año, que luego volveré á mis honrados exercicios, y no me ha de faltar Reyno que gane $y$ aloun Condado que darte. Dios lo oiga, dixo Sanne, y algun Condo siempre he oido decir, cho, y el pecado sea sordo, que siempre he oido decir, que mas vale buena esperanza, que ruin posesion. En esto estaban, quando entró Don Antonio, diciendo, con muestras de grandísimo contento: albricias, señor Don Quixote, que Don Gregorio y el renegado que fué por él, 
estí en la playa ¿que digo en la playa? ya estí en casa del Visorcy, y será aquí al momento. Alegróse alusun tanto Don Quisote, y dixo: en verdad que esroy por decir que mo hol gra que hubiera sucedido toso al reves, cir, que me holgara que hubiera succén to porque me obligara á pasar en Berberia, donde con la fucrza de mi brazo diera libertad, no solo á Don (iregorio sino á quantos christianos cautivos hay en Berbe2, Pero ¿que digo, miscrable? ¿No soy yo el vencido? ;no soy yo el derribado? a no soy yo el que no pucdo tomar arma cn un año? ¿Pues que prometo? ¿ de que me alabo, si ántes me conviene usar de la ruceca, que de la espada? Déxese deso, señor, dixo Sancho: viva la gallina aunque con su pepita, que hoy por ti, y mañana por mí, y en estas cosas de encuentros y porrazos, no hay tomarles tiento alguno, fues el que hoy cac, puede levantarse mañana, sino es que se quiera estar en la cama : quicro decir, que se dexe desmayar, sin cobrar nuevos brios para nuevas pendencias: y levíntese vucsa merced agora para recebir á Don Gregorio, que me parece cue anda la gente alborotada, y ya debe de estar en casa. Y así cra la verdad, porque habiendo ya dado cuenta Don Gregorio y cl renegado al Visorcy, de su ida y vucl ta, deseoso Don Gregorio de ver á Ana Félix, vino con cl renegado á casa de Don Antonio, y aunque Don Gregorio quando le sacáron de Argel fué con hábitos de muger, en el barco los trocó por los de un cautivo que salió consigo; pero en qualquiera que viniera, mostrara ser persona para ser codiciada, servida y estimada, porque eria hermoso sobreminera, y la edad, al parecer, de dicz y siete, ó diez y ocho años. Ricote y su hija saliéron recebirle, el padre con lágrimas y la hija con honestidad.
No se abrazíron unos á otros, porque donde hay mucho amor, no suele haber demasiada desenvoltura. Las dos bellezas juntas de Don Gregorio y Ana Félix admiráron en parricular á todos juntos los que presentes estaban. Fil silencio fué alli cl que habló por los dos amantes, y los ojos fuéron las lenguas, que descubriéron sus alegres y honestos pensamientos. Contó el renegado la industria y medio que tuvo para sacar á Don Gregorio. Contó Don Gregorio los peligros , y aprietos en que se habia visto con las mugeres con quien habia quedado, no con largo razonamiento, sino con breves palabras, donde mostró , que su discrecion se adelantaba á sus años. Finalmente Ricote pagó y satisfizo liberalmente, así al renegado, como á los que habian bogado al remo. Reincorporóse y redúxose el renegado con la Iglesia, y de miembro podrido volvió limpio y sano con la penitencia y el arrepentimiento. De allí á dos dias trató el Visorey con Don Antonio que modo tendrian para que Ana Félix, y su padre quedasen en España, pareciéndoles no ser de inconveniente alguno que quedasen en ella hija tan christiana y padre al parecer tan bien intencionado. Don Antonio se ofreció venir á la Corte á negociarlo, donde habia de venir forzosamente á otros negocios, dando á entender, que en ella, por medio del favor y de las dídivas, muchas cosas dificultosas se acaban. No, dixo Ricote, que se halló presente á esta plítica, hay que esperar en favores, ni en dádivas, porque con el gran Don Bernardino de Velasco, Conde de Salazar, á quien dió Su Magestad cargo de nuestra expulsion, no valen ruegos, no promesas, no dúdivas, no lástimas, porque aunque es verdad que él mezcla la miscricordia con la 
280

DON QUIXOTE DE IA MANCHA

justicia, como él ve que todo el cuerpo de nucstra nacion esta contaminado $y$ podrido usa con él antes del cauterio que abrasa, que del ungüento que molifica, y así con prudencia, con sagacidad, con diligencia y con miedos que pone, ha llevado sobre sus fuertes hombros á debida crecucion el peso desta gran mácuina, sin que nuestras industrias, estratagemas, solicitudes $y$ fraudes hayan podido deslumbrar sus ojos de Argos, que contino ticne alerta, porque no se le quede, ni encubra ninguno de los nuestros, que como raíz escondida, con el tiempo venga despues á brotar, y á echar frutos venenosos en España, ya limpia, ya descmbarazada de los temores en que nuestra muchedumbre la tenia. Heroyca resolucion del gran Filipo Tercero, y inaudita prudencia en haberla encargado al tal Don Bernardino de Velasco. Una por una, yo haré, puesto allá, las diligencias posibles, y haga el Cielo lo que mas fucre servido, dixo Don Antonio : Don Gregorio se irá conmign á consolar la pena que sus padres deben tener por su ausencia: Ana $\mathrm{Fe}$ lix se quedorú con mi muger en mi casa ó en un monasterio, y yo sé que el señor Visorey gustará se quedo en la suya el buen Ricote, hasta ver como yo negocio. IE Visorey consintió en rodo lo propuesto; pero Don Gregorio sabicndo lo quc pasaba dixo que cn ninguna ma nera podia ni queria dexar á Donia Ana Félix; pero teniendo intencion de ver á sus padres, $y$ de dar traza de volver por ella, vino en el decretado concierto. Quedósc Ana Félix con la muger de Don Antonio, y Ricote en casa del Visorcy. Llecóse el dia de la partida de Don Antonio, y el.de Don Quixote y Sancho, que fué de allí á otros dos: que la caida no le concedió que mas presto
PARTEII. CAPITUIO LXV.

se pusiese en camino. Hubo lígrimas, iubo suspiros, desmayos y sollozos al despedirse Don Gregorio de Ana Fé lix. Ofiecióle Ricote á Don Gregorio mil escudos, si los queria; pero él no tomo ningruno, sino solos cinco, que le prestó Don Antonio, prometiendo la paza dellos en la Corte. Con esto se partiéron los los, y Don (uivote y Sancho despues, como se ha dicho: Don Quivote desarmado y de camino, Sancho á pie, por ir el rucio cargado con lis armas.

\section{CAPITULO IXVI.}

Pue trata de lo gue verá el que lo líerese ó lo oirí al que lo escuchatic leer.

Al salir de Barcelona, volvió Don Quixote á mirar el sitio donde habia caicio, y dixo: aquí fuć Troya, aqu mi desticha, y no mi cobardía se llevó mis alconzadas glorias : aqui usó la fortuna conmigo de sus vultar y revucltis, aquí se escureciéron mis hazanas: agui finelinente cayó mi ventura, para jamas levanarase. Oyenco lo qual Sancho, diso : tan de valientes corazones es, senor mio, tener sufrimiento en las deseracias, cono alcgría en las prospcridades: y csto lo juzgo por mí mismo, que si quando era Gobernador estaba alegre, agora que soy escudero de á pie, no estoy triste : porque he oido decir, que esta que llaman por alí fortuna, es una muger borracha $y$ untojadiza, $y$ sobre todo ciega, $y$ ant no Ter bor ve lo que hace, ni sabe ás quncho, respontió Don Quixote, muy á lo discreto lasblas, no sé quicn te lo enseña. Lo que te sé decir es, que no hay fortunia en el mum!o, Tom. iv 
282

DON QUTXOTE DE IA MANCHA

ni las cosas que en él suceden, buenas, ó malas que scan, vienen acaso, sino por particular providencia de los Ciclos, $\mathrm{y}$ de aquí vicne lo que sucle decirse, que cada uno es artífice de su ventura. Yo lo he sido de la mia; pero no con la prudencia necesaria, y así me han salido al gallarin mis presunciones, pues debiera pensar que al poderoso grandor del caballo del de la Bianca Luna, no podia resistir la flaqueza de Rocinante. Atrevíme en fin, hice lo que pude, derribáronme, y aunque perdí la honra, no perdí, ni puedo perder la virtud de cumplir mi palabra. Quando era caballero andante, atrevido y valien pe, con mis obras $y$ con mis manos acreditabo mis hechos, y agora quando soy escudero pedestre, acreditaré mis paIabras, cumpliendo la que dí de mi promesa. Camina pues, amigo Sancho, y vamos á tener en nucstra ticrra el año del noviciado, con cuyo encerramiento cobrarémos virtud nucva, para volver al nunca de mí olvidado excrcicio de las armas. Señor, respondió Sancho, no es cosa tan gustosa el caminar á pie, que me mueva, é incite á hacer grandes jornadas. Dexemos estas armas colgadas de algun árbol en lugar de un ahorcado, y ocupando yo las espaldas del rucio, levantados los pies del suelo, harémos las jornadas como vuesa merced las pidiere y midiere: que pensar que tengo de caminar á pie, $y$ hacerlas grandes, cs pensar en lo excusudo. Bien has dicho, Sancho, respondio Don Quixote: cuélguense mis armas por trofeo, $y$ al pic dellas, ó al rededor dellas grabarémos en los árboles lo que en el trofeo de las armas de Roldan estaba escrito

$$
\text { Nadie las mueva, }
$$

que estar no pueda

con Roldan á prucelia.
PARTEII. CAPITULO IXVII

Todo eso me parece de perlas, respondió Sancho, y si no fuera por la falta que para el camino nos habia de hacer Rocinante, tambien fuera bien dexarle colgado. Pues ni él, ni las armas, replicó Don Quixote, quicro que se ahorquen, porque no se diga, que á buen servicio, mal galurdon. Muy bien dice vuesa merced, respondió Sancho, porque, segun opinion de discretos, la culpa del asno no se ha de echar á la albarda: y pues deste suceso rucsa merced tiene la culpa, castíguese á sí mesmo, $y$ no revienten sus iras por las ya rotas $y$ sangrientas armas, ni por las mansedumbres de Rocinante, ni por la blandura de mis pies, queriendo que caminen mas de lo justo. En estas razones y pláticas se les pasó todo aquel dia, $y$ aun otros quatro, sin sucederles cosa que estorbase su camino, y al quinto dia á la entrada de un Luyar, hallíron á la puerra de un meson mucha gente, que por ser fiesta se estaba allí solazanda. Quando llegaba á cllos Don Quixote, un labrador alzó la voz diciendo: alguno destos dos señores que aquí vienen, que no conocen las partes, cirá lo que se ha de hacer en nuestra apucsta. Sí diré por cierto, respondió Don Quixote, con toda rectitud, si es que alcanzo á entendcrla. Es pues el caso, dixo el labrador, señor bueno, que un vecino deste Lugar tan gordo, que pesa once arrobas, desufió á correr á otro su vecino, que no pesa mas que cinco. Fué la condicion, que habian de correr una carrera de cien pasos con pesos iguales, y habiéndole preguntado al desafiador, como se habia de igualar el peso, dixo, que el desafiado, que pesa cinco arrobas, se pusiese seis de hierin ro á cuestas, y as co con las once del gordo. Eso no, dixo á esta sazon Sanтом. Iv. 
284

DON QUIXOTE DE IA MANCHA

cho, ántes que Don Quixote respondiese : y á mí, que ha pocos dias que salí de ser Gobernador y Jucz, como todo el mundo sabe, toca averiguar estas dudas, $y$ dar parecer en todo pleyto. Responde en buen hora, dixo Don Quixote, Sancho amigo, que yo no esroy para dar migas á un gato secun traigo alborotado y trastornado el juicio. Con esta licencia dixo Sancho á los labradores, que estaban muchos al rededor dél, la boca abierta, esperando la sentencia de la suya: hermanos, lo que cl gordo pide no lleva camino, ni tiene sombra de justicia alo que se dice, que el desafia do puede escoger las armas, no es bien que este las escoja tales, que le impidan, ni estorben el salir vencedor y así es mi parccer, que el gordo desafiador se cscamonde monde entresaque pula y atilde, y sacue seis arrobas de sus carnes, de aquí, ó de allí de su cuerpo, como mejor le parecicre y estuvicre, y desta mancra quedando en cinco arrobas de peso, se igualará y ajustara con las cinco de su contrario, $y$ así podrán correr iqualmenre. Voro á tal, dixo un labrador, que escuchó la sentencia de Sancho, que este señor ha hablado como un bendito, y sentenciado como un Canónigo ; pero á buen seguro que no ha de querer quitarse el gordo una onza de sus carnes, quanto mas seis arrobas. Lo mejor es que no corran, respondió otro, porque el flaco no se muela con el peso, ni el gordo se descarne, y échese la mitad de la apuesta en vino, y llevemos estos señores á la taberna de lo caro, y sobre mí la capa quando llueva. Yo, señores, respondió Don Quixote, os lo agradezco; pero no puedo detenerme un punto, porque pensamientos $y$ sucesos tristes me hacen parecer descortes, y caminas
PARTEII. CAPITULO LXVI. mas que de paso: $y$ así dando de las espuelas á Rocinantc pasó adelante, dexándolos admirados de haber visto y notado, así su extraña figura, como la discrecion de su criacio, que por tal juzgáron á Sancho, $y$ otro de los labradores dixo isi el criado es tan discreto, qual debe de ser el amo? Yo apostaré, que si van a csuc lamanca, que á un tris han de venir á ser Alcaldes de Corte, que todo es burla, sino estudiar y mas estudiar, $y$ tener favor $y$ ventura, $y$ quando ménos se piensa el hombre, se hallia con una vara en la mano, ó con una mitra en la cabeza. Aquella noche la pasáron amo y mozo en mitad del campo al cielo raso y descubierto, y otro dia siguiendo su camino viéron que hásia ellos renia un hombre de á pie, con unas alforjas al cuello y una azcona, ó chuzo en la mano, propio talle de correo de á pie, el qual como llegó junto a Don Quixote, adelantó el paso, y medio corriendo llegó á él, y abrazín. dole por el muslo derecho, que no aicanzaba á mas, le dixo con muestras de mucha alegría : ó mi señor Don Quixote de la Mancha, y que gran contento ha de llegar al corazon de mi señor el Duque, quando sepa que vuesa merced ruelve á su castillo, que todavía se está en él con mi señora la Duquesa! No os conozco, amigo, respondió Don Quixote, ni sé quien sois, si vos no me lo decis. Yo, señor Don Quixote, respondió el correo, soy Tosílos el lacayo del Duque mi señor, que no quise pelear con vuesa merced sobre el casamiento de la hija de Doña Rodriguez. ¡Válame Dios! dixo Don Quixo-

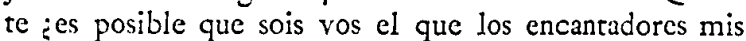
enemigos transformáron en ese lacayo que decis, por defraudarme de la honra de aquella batalla? Calle, scñor 
bueno, replicó el carrero, que no hubo encanto alguno,

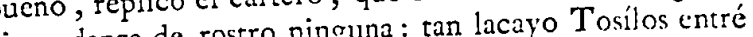
ni mudanza de rostro ninguna : tacayo salí della. Yo penen la cstacada, como Tos haberme parecido bicn la mosé casarme sin pelcar, peres mi pensamicnto, pues así za ; pero sucediome al reves mi pensamicastillo, of Ducomo vuesa merc que mi señor me hizo dar cien palos, por haber contraque mido á las ordenanzas que me tenia dadas ántes de envenido a las ordcnanzas que ha parado en que la muchacha trar en la batalla to Rodriguez se ha vuelto á Castilla, es ya monja, y Dona Rodrigucz se ha vuelto á Castilla, y yo voy ahora á Barcelona á llevar un plicgo de cartas I Virey, que le envia mi amo. Si vuesa merced quieal Virey, que le envia miente, puro, aquíllevo una care un traguito, aunque con no sé quantas rajitas de quelabaza llena de lo caro, conín de llamarivo $y$ despersa so de tronchon, que servirin de ilamaivo y desperador de la sed, si acaso está durmiendo. Quiero embite, dixo Sancho, y échese el resto de la cortesía, y, escancic tosílos á despecho y pesar de quantos encic el bucn Tosilos a dixo Don Quixote, En for dixo Don tú eres, Sancho, el mayor gloton del mundo, y el mayor ignorante de la ticrra, pues no te persuades que este corignorante de la ticra, posílos contrahecho: quédate con rco cs cncantado á poco, esel, y hartate, que yo me iré ad lante poco decó períndote á que vengas. Riose el lacayo, desenvayno su calabaza, desalforjó sus rajas, y sacando un panecillo, é y Sancho se sentáron sobic la yerba verde, y en buena

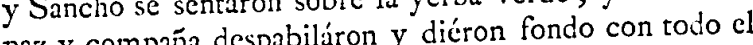
paz y compana despabilaron y dicron folientos, que larepuesto de las alforjas, con tan buenos alientos, que lamiéron cl pliego de las cartas, solo porque olia á queso. Dixo Tosílos á Sancho : sin duda este tu amo, Sancho amio debe de ser un loco. :Como debe? respondió San- cho, no debe nada á nadie, que todo lo paga, y mas quando la moneda es locura : bien lo veo yo, y bien se lo digo á él ; pero :que aprovecha? y mas agora que va rema tado, porque va vencido del caballero de la Blance Luna. Rogóle Tosílos le contase lo que le habia sucedido; pero Suncho le respondió, que cra descortesía dexar que su amo le esperase, que otro dia, si se encontrasen, habria lugar para cllo, y levantándose despues de haberse sacudido el sayo, y las migajas de las barbas, antecogió al rucio, y diciendo, á Dios, dexó á Tosílos, y alcanzó á su amo, que á la sombra de un árbol le estaba esperando.

\section{CAPITULO LXVII.}

De la resolucion aue tomó Don Ouixole de hacerse pastor y segruir la vida del campo, en tanto que se pasaba el año de su promesa, con otros sucesos en vierdad

$\mathrm{Si}_{\mathrm{i}}$ muchos pensamientos futrigaban á Don Quivore íngustosos y bucnos. tes de ser derribado, muchos mas le futigáron despues de caido. A la sombra del árbol cstaba, como se ha dicho, y alli como moscas á la micl le acudian y picaban pensamientos. Unos iban al desencanto de Dulcinea, y otros á la vida que habia de hacer cn su forzosa retirada. Llegó Sancho, y alabóle la libcral condicion del lacayo Tosílos. Es posible, le dixo Don Quixore, que todavía , ó Sancho, pienses que aquel sea verdadero lacayo? Parece que se te ha ido de las miéntes haber visto á Dulcinea convertida y transformada en labradora, y al caballaro de los Espejos en el Bachilier Carrasco: obras todas de los encantadores, que me persiguen. Pero dime 
gora ; preguntaste á ese Tosílos, que dices, que ha heco de Alisidora, si ha lloracio mi ausencia, o si cho das manos del olvito los enamorados ha dexaco fa en las mi presencia la farigabun: No cran, pensamicnos que en mi presencia la fatigabun? No cran, respondió Sancho, los que yo tenia tales, que me dicscn boberías. ¿Curpo de mi! señor sen lugar a pregunta bora en términos de inquirir pena¿ está vuesa merced ahora cn te amorosos: Mim, Surcho, mientos agenos, especialmente amoros . Min dixo Don Quixote, mucha difurencia hay de las obras cue se hacen por amor, á las que se hacen por agradecique se hacen por amor a das que caballero sca desimorado; miento. Bien puede hablando en todo rigor, que sea despero no puede ser, hablando al toceer Alisicion dioagradecido. Quísome bien, al parecer, Alintora, thome los tres tocadores que sabes, lloro en mi partica, maldíxome, vituperóme, quejóse á despecho de la vergüindíblicame que me aloraba: que za publicamente: schales todas de qu maldiciones. Yo las iras de los amantes suclen parur en malticions. no tuve esperanzas que darle, ni tesorn que ofrcerle, porque las mias las tengo entregadas á Dulcinca, y los porque la los como los de tesoros de los caballoros andantes $y$ solo puedo darle estos duendes, aparcntes y falsos, y solo pucdo darle estos acuerdos que della tengo, sin perjucio empero de los que tengo de Dulcinca, á quien tú agravias con la rem: sion son que tienis de lobos, que quicren guardarse ántes vea yo comidas de lobos, que quicren guardarso ances para los gusanos, que para el remedio de aquella pobre Señora. Suñor, respondió Sancho, si va á decir la ver dad, yo no me puedo persuadir que los azotes de mis dad, posaderas teng an we si dixécemos: si os duele la cabecantados, que cs como si dixécemos: si os duele la cabe-

quantas historias vuesa merced ha leido, que tratan de andante caballeria, no ha visto algun desencantado por azoies; pero por sí, ó por no, yo me los daré quando tenga gana ! el tiempo mé dé comodidad para castigarme. Dios lo haga, respondió Don Quixote, y los Cielos te den gracia para que caigas en la cuenta, y en la obligacion que te corre de ayudar á mi Señora, que lo es tuya, pues tii cres mio. En estas pláticas iban siguiendo su camino, quando Ilegáron al mesmo sirio, y lugar donde fuéron atropellados de los toros. Reconocióle Dor Quixote, y dixo á Suncho: este es el prado donde topámos á las bizarras pastoras y gullardos pastores, que en él querian renovar é imitar á la pastoral Arcadia, pensamiento tan nuevo como discreto, á cuya imitacion si cs que í ti te parece bien, querria, ó Sancho, que nos convirtiésemos en pastores, siquicra el tiempo que tengo de estar recogido. Yo compraré algunas ovejas, y tcias las demas cosas que al pastoral exercicio son necesarias, $y$ Ilamándome yo cl pastor Quixotiz, y tú cl pastor Pancino, nos andarémos por los montes, por las selvas $y$ por los prados, cantando aquí, endechando allí, bebiendo de los líquidos cristales de las fuentes ó ya de los limpios arroyuelos ó de los caudolosos rios. Darínos con abundantísima mano de su dulcísimo fruto las cncinas, asicnto los troncos de los durísimos alcornogues, sombra los sauces, olor las rosas, alfombras de mil colores matjzadas los extendidos prados, aliento el ayre claro y puro, luz la luna $y$ las estrellas, a pesar de la escuridad de la noche, gusto el canto, alegría cl lloro, Apolo versos, cl amor conceptos, con que potrémos hacernos cternos $y$ fimosos, no solo en los presentes, rom. 1 . 
me ha quadrado, $y$ aun csquinado tal género de vida, y mas que no la ha de haber aun bien visto el Bachiller Sanson Carrasco y Maese Nicolas el Barbero, quando is han de querer seguir, $y$ hacerse pastores con nosotros, y aun quiera Dios no le venga en voluntad al Cura de entrar tambien en el aprisco, segun es de alcgre Y amigo de holgarse. 'Tú has dicho muy bien, dixo Don Quixore, y podrá llamarse el Bachiller Sansun Carrasco, si entra en el pastoral gremio, como entrará sin duda, cl pastor Sansonino, ó ya el pastor Carrascon : cl Barbero Nicolas se podrá llamar Niculoso, como ya el antiquo Boscan se llamó Nemoroso : al Cura no sé que nombre le pongamos, sino es algun derivativo de su nombre, llamándole el pastor Curiambro. Las pastoras de quien hemos de ser amantes, como entre peras podrémos escoger sus nombres, y pues el de mi Señora quadra, así al de pastora, como al de Princesa, no hay para que cansarme en buscar otro que mejor le venga: tú, Sancho, pondrás á la tuya el que quisicres. No pienso, respondió Sancho, ponerle otro alguno, sino el de Teresona, que le vendrá bien con su gordura y con el propio que tienc, pues se llama Teresa, y mas que celebrándola yo en mis versos, vengo á descubrir mis castos deseos, pues no ando á buscar pan de trastrigo por las casas agenas. El Cura no será bien que tenga pastora, por dar buen excmplo, y si quisiere el Bachiller tenerla, su alma en su palma. ¡Válame Dios, dixo Don Quixote, y que vida nos hemos de dar, Sancho amigo! i Que de churumbelas han de llegar á nuestros oidos, que de gaytas zamoranas, que de tamborines y que de sonajas y que de rabcles! :Pues que si entre" estas diferencias de músicas re suena la de los albogues? Allí se verán casi todos los instrumentos pastorales. : Que son albogucs? preguntó $S_{3 n-}$ cho, que ni los he oido nombrar, ni los he visto en to da mi vida. Albogues son, respondió Don Quixote, unas chapas á modo de candcleros de azófar, que dando una con otra por lo vacio y hueco, hace un son, si no muy agradable, ni armónico, no descontenta, y viene bien con la rusticidad de la gayta y del tamborin, y este nombre aibogues cs Morisco, como lo son todos aquellos que en nucstra lengua castellana comienzan en al: conviene á saher, almolaaza, almor aar, alhombra, alguacil alhuremat", almacen, alcancía, y otros semejantes, que deben ser pocos mas, $y$ solos tres tiene nuestra lengua, que son Moriscos, y acaban en , $i, \mathrm{y}$ son borcegtu $i, z a-$ quizami, y maravedi: alheli, y allaqui, tanto por el al primero, como por el $i$, en que acaban, son conocidos por Aríbigos. Esto te he dicho de paso, por habérmclo reducido á la memoria la ocasion de haber nombrato albogues: $y$ hanos de ayudar mucho á practicar" con perfecion este cxercicio, el scr yo algun tanto pocta , como tú sabes, y el serlo tambien en cxtremo el Bachiller Sanson Carrasco. Del Cura no digo nada; pero yo apostaré que debe de tener sus puntas y collares de poeta, y que las tenga tambien Maese Nicolas, no dudo en ello, porque todos, ó los mas son guitarristas y copleros. Yo me quejaré de ausencia: tú te alabarís de firme enamorado: cl pastor Carrascon de desdeñado, y el Cura Curiambro de lo que él mas puede servirse, y ásí andará la cosa que no haya mas que desear. A lo que respondió Sancho: yo soy, señor, tan desgraciado, que temo no ha de llegar TOM. Iv. 
el dia en que en tal exercicio me vea. ¡O que polidas cucharas tengo de hacer quando pastor me vea!; Que de migas, que de natas, que de guirnaldas, y que de zarandajas pastoriles! que puesto que no me grangeen fama de discreto, no dexarán de grangearme la de ingenioso. Sanchica mi hija nos llevarí la comida al hato. ¡Pero nios. liciosos que simples, y no querria que fucse por lana, $y$ volviese trasquilada: y tambien suclen andar los amores y los no buenos descos por los campos, como por las cilldades y por las pastorales chozas, como por los Reales Palacios, y quitada la causa, se quita el pecado, y ojos que no ven, corazon que no quicbra, y mas vale salto de mata, que ruego de hombres buenos. No mas refranes, Sancho, dixo Don Quixote, pues qualquicra de los que has dicho basta para dar á entender tu pensamicnto: $y$ muchas veces te he aconsejado, que no scas tan pródigo de refranes, y que te vayas á la mano en decirlos; pero paréceme que es predicar en desierto: $y$, castígame mi parce me que cs predicar cn desierco: $y$, candió Sancho, madre, $y$ yo trompogelas. que vuesa merced es como lo que dicen : dixo la sarten á la caldera, quítate allá ojinegra. Estáme reprehendiendo que no diga yo refranes, y ensártalos vuesa merced de dos en dos. Mira, Sancho, respondió Don Quixote, yo traigo los refranes á propósito, y vienen quando los digo, como anillo en el dedo; pero tráeslos tú tan por los cabellos, que los arrastras, y no los guias: y si no me acuerdo mal, orra vez te he dicho, que los refranes son sentencias breves sacadas de la experiencia y especulacion de nuestros antiguos sabios, y el refran que no viene propósito, ántes es disparate que sentencia. Pero dexé-
PARTEII. CAPÍTULO IXVII. monos desto, y pues ya viene la noche, retirémonos del camino real algun trecho, donde pasarémos esta noche, y Dios sabe lo que será mañana. Retiráronse, cenáron tarde y mal, bien contra la voluntad de Sancho, á quien se le representaban las estrechezas de la andante caballería usadas en las selvas y en los montes, si bien tal vez la abundancia se mostraba en los castillos y casas, así de Don Diego de Miranda, como en las bodas del rico Camacho y de Don Antonio Moreno; pero censideraba no ser posible ser siempre de dia, ni siempre de noche, $y$ así pasó aquella durmicndo, y su amo rclando.

\section{CAPITULO IXVIII.}

De la cerdosa aventura que le aconteció á Don Duixote. Er el ciclo, pero no en parte que pudiese ser vista, que tal vez la señora Diana se va á pasear á los antípodas, y dexa los montes negros y los valles cscuros. Cumplio Don Quixote con la naturalcza, durmiendo el primer sucño, sin dar lugar al segundo; bien al reves de Sancho, que nunca tuvo segundo, porque le duraba el sueño desde la noche hasta la mañana, en que se mostraba su buena complexîon y pocos cuidados. Los de Don Quixote le desveláron de manera, que despertó á Sancho, y le dixo: maravillado estoy, Sancho, de la libertad de tu condicion. Yo imagino, que eres hecho de mármol, ó de duto bronce, en quien no cabe movimiento, ni sentimiento alguno. Yo velo quando tú duermes, yo lloro quando cantas, yo me desmayo de ayuno, quando tú estás perezoso y desalentado de puro harto. De buenos criados 
294

DON QUIXOTE DE LA MANCHA

es conllevar las penas de sus señores, $y$ sentir sus sentimientos, por bien parecer siquiera. Mira la sereniimimos, que nos condad desta noche, la soledad ch que estimos, que nos convida á cntremeter alguna vigilia entre nuestro sucío. Le vántate por tu vida, $y$ desvíate algun trecho de aquí, y con buen ínimo y denuedo agradecido date trecientos, con bicn áno y des á buena cuenta de los del desencá quatrociento de Dulcin canto de Dulcinea : y esto rogando te lo suplico , que no quicro venir contigo á los brazos como la otra vez, porque sé que los tienes pesados. Despues que te hayas dado pasarćmos lo que resta de la noche, cantando yo mi ausencia y tú tu frrmeza, dando desde agora principio al cxercicio pastoral, que hemos de tener en nuestra aldea. Scíor respondió Sancho, no soy yo Religioso, para que desde la mitad de mi sucño me levante y me discipline, ni ménos me parece, que del extremo del dolor de los azotes se pueda pasar al de la música. Vuesa merced me dexe dormir, y no me apricte en lo del azomerme que me hará hacer juramento de no tocarme jatarme, que me hará hacer jurane apo de no tocarma jamas al pelo del sayo, no que al de mis carnes. iO alma cndurecida! ¡ $O$ escudero sin picdad! ¡ $O$ pan mal emplea do, $y$ mercedes mal consideradas las que te he hecho $y$ pienso de hacerte! Por mí te has visto Gobemador, y por mí te ves con esperanzas propinquas de ser Conde, ó tener otro título equivalente, $y$ no tardarí cl cumplimiento dellas mas de quanto tarde en pasar este año, que yo post túnebras spero lucem. No entiendo eso, repli-

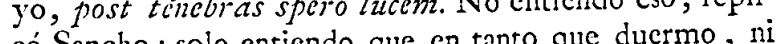
tengo temor, ni esperanza, ni trabajo, ni gloria, y bien haya el que inventó el sueño, capa que cubre todos los humanos pensamicntos, manjar que quita la hambre, agua
PARTEIT. CAPfTULO IXVII.

que ahuyenta la sed, fuego que calienta el frio, frio que templa el ardor, y finalmente moneda general con que to das las cosas se compran, balanza y peso que iguala al pastor con el Rey y al simple con el discreto. Sola una cosa tiene mala el sueño, segun he oido decir, y es, que se purece á la muerte, pues de un dormido á un muerto hay muy poca diferencia. Nunca te he oido hablar, Sancho, dixo Don Quixote, tan elegantemente como ahora, por donde vengo á conocer ser verdad el refran que tú algunas veees sueles decir: no con quien naces, sino con quien paces. i $A$ pesia tal! replicó Sancho: scñor nuestro ano, no soy yo ahora el que ensarta refranes, que tambien il vuesa mereed se le caen de la boca de dos en dos, mejor que á mí, sino que debe de haber entre los mios y los suyos esta diferencia, que los de ruesa merced vendrán á tiempo, y los mios á deshora; pero en efecto todos son refranes. En csto estaban quardo sintićron un sordo estruendo, $y$ un áspcro ruido, que por todos aquellos valles se extendia. Levantóse en pie Don Quixote, y puso mano á la espada, y Sancho se agazapó debaxo del rucio, poniéndose á los lados el lio de las armas y la albarda de su jumento, tan tembiando de miedo , como alborotado Don Quixote. De punto en punto iba creciendo el ruido y llegándose cerca í los dos temerosos: aloménos al uno, que al otro ya se sabe su valentía. Es pues el caso que llevaban unos hombres á vender á una feria mas de seiscicntos puercos, con los quales caminaban á aquellas horas, y cra tanto el ruido que llevaban, y el gruñir y el bufar, que ensordeciéron los oidos de Don Quixote y de Sancho, gare no advirtiéron lo que ser podia. Llegó de tropel la cxtendidal y gruñi- 
dora piara $y$ sin tener respeto á la autoridad de Don Quixore, ni á la de Sancho, pasúron por cima de los dos, deshaciendo las trincheas de Suncho, y derribando no so10 á Don Quixote, sinollevando por añadidura á Rocinante. El tropel, el gruñir, la presteza con que llegáron los albarda, á las armas, al rucio á Rocinante, á Sancho y á 1)on Quixorc. Levantóse Sancho como mejor pudo, y pidió í su amo la espada, diciéndole que queria matar media docena de aquellos scínores y descomedidos puercos : que ya habia conocido que lo cran. Don Quixote de dixo: déxalos cstar, amigo, que csta afrenta es pena de mi pecado, y jurto castigo del Ciclo es, que á un caballero andante vencido le coman adivas, y le piquen avispas y le hollen puercos. Tambien debe de ser castigo del Ciclo, respondió Sancho, que á los escuderos de los caballeros vencidos los puncen moscas, los coman piojos y les cmbista la hambre. Si los escuderos fućramos hijos de los cuballeros á quien scrvimos, ó parientes suyos muy ccrcunos, no fuera mucho que nos alcanzara la pena de sus culpas hasta la quarta gencracion. Pero a que lienen que ver los Panzas con los Quixotes? Ahora bien tornémonos á acomodar, y durmámos lo poco que queda de la noche, y amanecerá Dios y medrarémos. Duerme tú, Siancho, respondió I)on Quixote, que nacíste para dormir, que yo que nací para velar, en el tiempo que falta de ayuí al dia, daré rienda á mis pensamientos, $y$ los desfogaré en un Madrigalete, que sin que tú lo sepas, á noclie compuse en la memoria. A mí me parece, respondió Sancho, que los pensumientos que dan lugar á hacer coplas, no deben de ser muchos: vucsa merced coplée
PARTE II. CAPITULO IXVIIT. 297 quanto quisiere, que yo dormiré quanto pudiere, y luego tomando en el suelo quanto quiso, se acurrucó , y durmió á sucino suclto sin que fianzas, nideudas ni do lor alguno se lo cstorbasc. Don Quixote arrimado á un tronco de una haya, ó de un alcornoque (que Cide $\mathrm{Ha}$ mete Benengeli no distingue el árbol que cra) al son de sus mesmos suspiros cantó desta suerte:

$$
\begin{aligned}
& \text { Amor, quando yo pienso } \\
& \text { En ol mal que me das, terrible y fuerte, } \\
& \text { Voy corriendo á la muerte, } \\
& \text { Pensando asi acabar mi mal inmenso: } \\
& \text { Mas en llegando al pason, }
\end{aligned}
$$

Cada verso destos acompañaba con muchos suspiros y no pocas lígrimas, bien como aquel cuyo corazon tenia traspasado con el dolor del vencimiento y con la ausencia de Dulcines. Ilecóse en esto el dis dió cl sol con sus rayos en los ojos á Sancho: despertó, y esperczósc, sacudiéndose y estirándose los perczosos miembros: miró el destrozo que habian hecho los puercos en su repostcría, $\mathrm{y}$ maldixo la piara, y aun mas adelantc. Finalmente vol vićron los dos á su comenzado camino, y al declinar de la tarde vićron que hácia ellos venian hasta dicz hombres том. sN. 
DON QUIXOTE DE IA MANCHA

de á caballo y quatro, ó cinco de á pie. Sobrcsaltóse el corazon de Don Quixote, y azoróse el de Sancho, porque la gente que se les llegaba traia lanzas y adargas, $y$ venia muy á punto de guerra. Volvióse Don Quixote á Sancho, y díxole: si yo pudiera, Sancho, exercitar mis armas, y mi promesa no me hubicra atado los brazos, csta máquina que sobre nosotros viene, la tuviera yo por tortas y pan pintado ; pero podria ser fuese otra cosa de 1a que tememos. Llegáron en csto los de á caballo, y arbolando las lanzas, sin hablar palabra alguna, rodcúron á Don Quixote, y se las pusiéron á las espaldas y pechos, amenazándole de muerte. Uno de los de á pie, puesto un dedo en la boca en señal de que callase, asió del freno de Rocinante, y le sacó del camino, y los demas de á pie, antecogiendo á Sancho y al rucio, guardando todos maravilloso silencio, siguiéron los pasos del que llevaba á Don Quixote, el qual dos, ó tres veces quiso preguntar adonde le llevaban, ó que querian : pero apénas comenzaba á mover los labios, quando se los iban a cerrar con los hierros de las lanzas: y á Sancho le acontecia lo mismo, porque apénas daba muestras de hablar, quando uno de los de á pie con un aguijon le punzaba, $y$ al rucio ni mas, ni ménos, como si hablar quisiera. Cerró la noche, apresuráron el paso, ereció en los dos presos el miedo, y mas quando oyéron, que de quando en quando les decian : caminad Trogloditas, callad bár baros, pagad antropófagos, no os quejeis Scitas, ni abrais los ojos Polifemos matadores, leones carniceros, y otros nombres semejantes á estos con que atormentaban los oidos de los miscrables amo y mozo. Sancho iba diciendo entre sí: ; nosotros tortolitas, nosotros barberos, ni es-
PARTE II. CAPfTULO LXVIIT.

tropajos, nosotros perritas, á quien dicen, cita , cita? No me contentan nada estos nombres, á mal viento va esta parva, todo el mal nos viene junto, como al perro los palos, y oxalí parase en ellos lo que ameniza esta aventura tan desventurada. Iba Don Quixote embelesado, sin poder atinar con quantos discursos hacia, que serian aquelios nombres lienos de vituperios, que les ponian, de los quales sacaba en limpio, no esperar ningun bien, y temer mucho mul. Llegáron en esto un liora casi de la noche á un castillo, que bien conoció Don Quixore que cra el del Duque, donde habia poco que habian estado. ¡Válame Dios! dixo aś como conocio la estancia, y aque será esto? Sí yue en esta casa todo es cortesía y buen comedimiento; pero para los vencidos el bien se vuelve en mal , y el mal en peor. Entráron al patio principal del castillo, y viéronle aderezado y puesto de mancra, que les acrecentó la admiracion, y les dobló el miedo como se verí en el siguiente capítulo.

\section{CAPITULO LXIX.}

Del mas ram, y mas nuevn suceso que en todo ol discurso desta grande historia avino i Don ?uixote.

A peíronse los de á caballo, y junto con los de á pic tomando en peso y arrebatadamente á Suncho y á Don Quixote, los entráron en el patio, al rededor del qual ardian casi cien hachas puestas en suss blandones, y por los corredores del patio mas de quinientas luminarias, de modo, que á pesar de la noche, que se mostraba algo escura, no se echaba de ver la falta del dia. En medio del pario se levantaba un túmulo como dos varas del sueTrim. Iv. ip ij 
300

DON CUIXOTE DE LA MANCIA

lo, cubierto todo con un grandísimo dosel de terciopclo negro, al rededor del qual por sus gradas ardian velas de cera blanca sobre mas de cien candeleros de plata, encima del qual túmulo se mostraba un cuerpo mucro de una tan hermosa doncella, que hacia parecer con su hermosura hermosa á la misma mucrte. Tenia la cabeza sobre una almohada de brocado, coronada con una guirnalda de diversas y odoriferas flores texida, las manos cruzadas sobre el pecho, y entre ellas un ramo de amarilla y vencedora palma. A un lado del patio estaba puesto un teatro, y en dos sillas sentados dos personages, que por tener coronas en la cabeza y cetros en las manos daban señales de ser algunos Reyes, ya verdaderos, ó ya fingidos. Al lado deste teatro, adonde se subia por algunas gradas, estaban otras dos sillas, sobre las quales los que truxéron los presos sentáron á Don Quixote y á Sancho, todo esto callando, y dándoles á entender con señales á los dos, que asimismo callasen; pero sin que se lo señalaran, callaran ellos, porque la admiracion de lo que estaban mirando les tenia atadas las lenguas. Subiéron en esto al teatro con mucho acompañamicnto dos principales personages, que lucgo fuéron conocidos de Don Quixote ser el Duque y la Duquesa sus huéspedes, los quales se sentáron en dos riquísimas sillas junto á los dos que parecian Reyes. ¿Quien no se habia de admirar con esto, añdiéndose á cllo haber conocido Don Quixote, que el cuerpo muerto que estaba sobre el túmulo, cra el de la hermosa Altisidora? Al subir el Duque y la Duquesa en el teatro, se levantáron Don Quixote y Sancho, y les hiciéron una profunda humillacion, y los Duques hiciéron lo mesmo, inclinando algun tanto las cabczas. Salió
PARTE IT. CAPITULOIXIX. 301 en esto de traves un ministro, y llegándose á Sancho le echó una ropa de bocací negro cncima, toda pintada con llamas de fuego, y quitándole la caperuza, le puso en la cabeza una coroza, al modo de las que sacan los penitenciados por el Santo Oficio, y díxole al oido, que no descosicse los labios, porque le echarian una mordaza, ó le quitarian la vida. Mirábase Sancho de arriba abaxo, veíase ardiendo en llamas; pero como no le quemaban no las estimaba en dos arditcs. Quitóse la coroza, vióla pintada de diablos, volviósela á poner, diciendo entre sí: aun bien que ni ellas me abrasan, ni ellos me llevan. Mirábale tambien Don Quixote, y aunque el temor le tenia suspensos los sentidos, no dexó de reirse de ver la figura de Sancho. Comenzó en esto á salir, al parecer, debaxo del túmulo un son sumiso y agradable de flautas, que por no ser impedido de alguna humana voz, porque en aquel sitio el mesmo silencio guardaba silencio, asimismo se mostraba blando y amoroso. Lucgo hizo de sí improvisa muestra junto á la almohada del, al parecer, cadáver un hermoso mancebo, vestido á lo Romano, que al son de una arpa, que él mismo tocaba, cantó con suavísima y clara voz estas dos estancias:

En tanto que en si vuclve Altisidora, Muerta por la crueldad de Don Quixote, $Y$ en tanto que en la Corte encantadora Se vistieren las damas de picote,

$Y$ en tanto que á sus ducñas mi señora

Vistiire de bajeta $y$ de anascote,

Cantaré su belleza y su desgracia,

Con mejor plectro, que el cantor de Tracia. 
$Y$ aun no se me figura, que me toca Aatleste oficio solamente en wida Mas con la lengua muerta jo fria en la boca Pienso mover la voz á ti debida. Libre mi alma de su estrecha roca, Por el Estigio lago condacida,

Colcbrándote irá: y aquel sonido

Hará parar las aguas del olvido.

No mas, dixo á esta sazon uno de los dos oue parccian Reyes: no mas, cantor divino, que seria proceder en infinito representarnos ahora la mucrte y las gracias do la sin par Altisidora, no muerta, como el mundo ignorante piensa, sino viva en las Ienguas de la fama, y cn la pena, que para volverla á la perdida luz ha de pasar Sancho Panza, que está presente : y así , ó tú 'Radamanto, que conmign juzgas en las cavernas lóbregas de Dite, pues sabes rodo aquello que en los inescrutables hados esta dicterminado, acerca de volver en sí esta donecila, dilo y decláralo luego, porque no se nos dilate el bien que con su nucva vuclta esperamos. Apénas hubo dicho esto $M$ inos, juez y compañero de Radamanto, quando levantondose en pie Radamanto, dixo: ea, ministros desta casa, altos y baxos, grandes y chicos, acudid unos tras otros, $y$ sellad cl rostro de Sancho con veinte y quatro mamonas, y doce pellizcos, y seis alfilerazos en brazos y lomos, que en esta ceremonia consiste la salud de Altisidora. Oycndo lo qual Sancho Panza, rompió cl silencio, y dixo: voto á tal, así me dexe yo sellar el rostro, ni manosearme la cara, como volverme Moro. C Cuerpo de mit ¿que tiene que ver manoscarme el rostro, con la resur- reccion desta doncella: Regostóse la vieja á los bledas: encantan á Dulcinea, y azótanme para que se desencante: muérese Altisidora de males que Dios quiso darle, y hana de resucitar hacerme á mí veinte y quatro mamonas, y acribarme el cuerpo á alfilerazos, y acardenalarme los brazos á pellizcos. Esas burlas á un cuñado, que yo soy perro vicjo, y no hay conmigo tus, tus. Morirás, dixo en alta voz Radamanto: ablándate tigre, humillate Nembrot soberbio, y sufre y calla, pues no te piden imposibles, $y$ no te metas en averiguar las dificultades deste negocio: mamonado has de ser, acrubillado te has de ver, pellizcado has de gemir. Ea, digo, ministros, cumplid mi mandamiento; si no, por la fe de hombre de bien, que habeis de ver para lo que nacísteis. lareciéron en esto, que por el patio venian hasta seis dueñas en procesion, una tras otra, las quatro con antojos, $y$ todas levantadas las manos derechas en alto, con quatro dedos de muñecas de fuera, para hacer las manos mas largas, como ahora se usa. No las hubo visto Sancho, quandc bramando como un toro, dixo: bien podré yo dexarme manosear de todo $\mathrm{cl}$ mundo; pero consentir que me toquen ducñas, eso no. Gatécnme el rostro, como hiciéron á $\mathrm{mi}$ amo en este mesmo castillo: traspásenme el cucrpo con puntas de dayas buidas : atenácenme los brazos con renoza de fucgo, que yo lo lleraré en paciencia ó serviré á estos señores; pero que me toquen dueñas, no lo conscntiré, si me llevase el diabio. Rompió tambien el ilencio Don Quixote, diciendo á Sancho:ten paciencia, hijo, $y$ da gusto a estos seirores, $y$ muchas gracias al Cielo, por haber puesto tal virtud en tu persona, que con el martirio della desencantes los encantados, $y$ resucite 
304

DON QUTXOTE DE LA MANCHA

los mucrtos. Ya estaban las dueñas cerca de Sancho, quando él mas blando y mas persuadido, poniéndose bien en la silla, dió rostro y barba á la primera, la qual le hizo una mamona muy bien sellada, y luego una gran reverencia. Ménos cortesía, ménos mudas, señora due ña, dixo Sancho, que por Dios que traeis las manos oliendo á vinagrillo. Finalmente todas las ducńas le selláron, y otra mucha gente de casa le pellizcáron; pero lo que él no pudo sufrir, fué el punzamiento de los alfileres, y así se levantó de la silla, al parecer mohino, y asiendo de una hacha encendida, que junto á él estaba, dió tras las ducñas, y tras todos sus verdugos, diciendo : afuera, ministros infernales, que no soy yo de bronce para no sentir tan extraordinarios martirios. En esto Altisidora, que debia de estar cansada, por haber estado tanto tiempo supina, se volvió de un lado: visto lo qual por los circunstantes, casi todos á una voz dixéron : viva es Al tisidora, Altisidora vive. Mandó Radamanto á Sancho, que depusiese la ira, pues va se habia alcanzado el intento que se procuraba. Así como Don Quixote vió rebullir á Altisidora, se fué á poner de rodillas delante de Sancho, diciéndole : agora es tiempo, hijo de mis entranas, no que escudero mio, que te dés algunos de los azotes, que estás obligado á darte por el desencanto de Dulcinea ". Ahora digo, que es el tiempo donde tienes sazonada la virtud, y con eficacia de obrar el bien que de ti se espera. A lo que respondió Sancho: esto me parece argado sobre argado, $y$ no miel sobre hojuelas : bueno seria, que tras pellizcos, mamonas y alfilerazos viniesen ahora los azotes: no tiencn mas que hacer, sino tomar una gran piedra, y atármela al cuello, y dar conmigo en
PARTE IT. CAPÍTULO LXIX.

un pozo, de lo que á mí no pesaria mucho, si es que para curar los males agenos tenero yo de ser la vaca de la boda. Déxenme, si no por Dios que lo arroje, y lo eche todo á treec, aunque no se venda. Ya en esto se habia sen tado en el túmulo Altisidora, y al mismo instante sonáron las chirimías, á quicn acompañáron las flautas y las roces de todos, que aclamaban : viva Altisidora, Altisi dora viva. Levantíronse los Duques y los Reyes Mínos y Radamanto, y todos juntos con Don Quixote y Sancho fuéron á recebir á Altisidora, y á baxarla del túmulo, la qual haciendo de la desmayada se inclinó á los Duques y á los Reyes, y mirando de traves á Don Quixote, le dixo : Dios te lo perdone, desamorado caballero, pues por tu crueldad he estado en el otro mundo, á mi parecer, mas de mil años : y á ti, ó el mas compasivo escudero que conticne el orbe, te agradezco la vida que posco. Dispon desde hoy mas, amigo Sancho, de seis camisas mias que te mando, para que hagas otras seis para ti, y si no son todas sanas, aloménos son todas jimpias. Besóle por cllo las manos Sancho con la coroza en la mano y las rodillas en el suclo. Mandó el Duque que se la quitasen, $y$ le volviesen su caperuza, $y$ le pusiesen el sayo, y le quitasen la ropa de las llamas. Suplicó Sancho al Duque que le dexasen la ropa y mitra, que las queria llevar á su tierra, por señal y memoria de aquel nunca visto suceso. La Duquesa respondió que sí dexarian, que ya sabia ćl quan grande amiga suya cra. Mandó el Juque despejar el patio, y que todos se recogiesen a sus estancias, y que á Don Quixote y á Sancho los llevasen á las que ellos ya se sabian.

TOM. IV. 


\section{CAPÍTULO LXX.}

Oue sigue al de sesenta y nueve, y trata de cosas no excusadas para la claridad desta historia.

Durmió Sancho aquella noche en una carriola, en el mesmo aposento de Don Quixote, cosa que él quisiera excusarla, si pudiera, porque bien sabia que su amo no le habia de dexar dormir á precruntas y á respuestas, y no se hallaba en disposicion de hablar mucho, porque los dolores de los martirios pasados, los tenia presentes, y no le dexaban libre la lengua, y viniérale mas á cuento dormir en una choza solo, que no en aquella rica estancia acompañado. Salióle su temor tan verdadero, y su sospecha tan cierta, que apénas hubo entrado su scñor en el lecho, quando dixo: :que te parece, Sancho, del suceso desta noche? Grande y poderosa es la fuerza del desden a Altisictora, no conotas saeras, ni con otra cspada, ni pada, ni con otro instrumento bélico, ni con venenos mortíferos, sino con la consideracion del rigor, $y$ el desden con que yo siemprc la he tratado. Muriérase ella en hora buena yo siemprc la he tratado. Muichase cespondió Sancho quando quisiera, y como quisiera, respondio Sancho, $y$ dexárame á mí en mi casa, pues ni yo la cnamoré, ni la desdeñé en mi vida. Yo no sé, ni puedo pensar como sea, que la salud de Altisidora, doncella mas antojadia , que divcrera, tenga que ver, como orra rez he dicho, con los martirios de Sancho Panza. Agora sí que vengo á conocer clara y distintamente, que hay cncantadores y encantos en el mundo, de quien Dios me libre, pues yo no me sé librar: con todo esto suplico á vue- sa merced me dexe dormir, y no me pregunte mas, si no quicre que me arroje por una ventana abaxo. Duerme, Sancho amigo, respondió Don Quixote, si es que te dan lugar los alfilerazos y pellizcos recebidos y las mamonas hechas. Ningun dolor, replicó Sancho, llegó á la afrenta de las mamonas, no por otra cosa, que por habémelas hecho dueñas, que confundidas sean: $y$ torno á suplicar á vuesa merced me dexe dormir, porque cl sucño es alivio de las miserias de los que las tienen des. piertas. Sea así, dixo Don Quixote, y Dios te acompañe. Durmiéronse los dos, y en este tiempo quiso escribir $y$ dar cuenta Cide Hamete, autor desta grande historia, que les movió á los Duques á levantar cl edificio de Ia máquina referida: $\mathrm{y}$ dice, que no habiéndosele olvidado al Bachiller Sanson Carrasco quando el caballero de los Espejos fui vencido y derribado por Don Quixote, cuyo vencimicnto $y$ caida borró y deshizo todos sus designios, quiso volver á probar la mano, esperando mcjor suceso que el pasalo: y así, informándose del page que lievó la carta y presente á Teresa Panza muger de Sancho, adondic Don Quixote quedaba, buscó nucvas armas y caballo, y puso en el cscudo la blanca luna, lievíndolo todo sobre un macho, á quien suiaba un labrador, y no Tomé Cecial, su antiguo escudero, porque no fuese conocido de Sancho, ni de Don Quixote. Llegó pues al castillo del Duque, que le informó el camino y derrota que Don Quixote llevaba con intento de hallarse en las justas de Zaragoza. Dixole asimismo las burlas que le habia hecho con la traza del desencanto de Dulcinea, que habia de ser á costa de las posaderas de Sancho. En fin dió cuenta de la burla que Sancho habia hecho á su amo, TOM. 1 . 
dindole á entender que Dulcinea estaba encantada y transformada en labradora y como la Duquesa su muger habia da á cntender á Sancho, que él era cl que se engaíaba, porque verdaderamente estaba encantada Dulcinea, de que no poco se rió y admiró el Bachiller, considerando la aqudeza y simplicidad de Sancho, como el exremo de la locura de Don Quixote Pidióle cl Duque cue si le hallase, y le venciese, ó no, se volviese por allí á darle cuenta del suceso. Hízolo así el Bachiller: partióse en su busca, no le halló en Zaragoza , pasó adelante, y sucedióle lo que queda referido. Volvióse por el castillo del Duque, y contósclo todo con las condiciones de Ia batalla, y que ya Don Quixote volvia á cumplir, como buen caballero andante, la palabra de retirarse un añ cn su aldea: en ol qual ticmpo podia ser divo cl Bachiller, que sanase de su locura, que esta cra la intencion que le habia movido á hacer aquellas transformaciones, por ser cosa de lástima, que un hidalgo tan bien entendido como Don Quivote fuese loco. Con esto se despidió del Duque, y se volvió á su Lugar, esperando en él á Don Quixote, que tras él venia. De aquí tomó ocasion el Duque de haccrle aquella burla : tanto era lo que gustaba de las cosas de Sancho y de Don Quixote, y hizo tomar los caminos cerca y léxos de cl castillo por todas las partes que imaginó que podria volver Don Quixote, con muchos criados suyos de á pie y de í caballo, para que por fucrza, ó de grado le truy de a caballo, para que por fucrán al Duque, el qual ya prevenido de todo lo que habia de hacer, así como tuvo noticia de su llegada, mandó encender las hachas y las luminarias del patio, $y$ poner a Altisidora sobre el túmulo, con todos los aparatos se han contado, tan al vivo $y$ tan bien hechos que do la verdad á cllos habia bien poca diferencia : y dice mas Cide Hamete, que tiene para sí ser tan locos los burladores, como los burlados, y que no estaban los Duques dos dedos de parecer tontos, pues tanto ahinco ponian en burlarse de dos tontos, los quales cl uno durmiendo í suelto, $\mathrm{y}$ cl otro velando á pensamientos desatados, les tomó cl dia, y la gana de levantarse: que las ociosas plumas, ni vencido, ni vencedor, jamas diéron gusto á Don Quixotc. Altisidora, en la opinion de Don Quixote vuclta de muerte á vida, siguiendo cl humor de sus señores, coronada con la misma guirnalda que en el túmulo tenia, y vestida una tunicela de tafutan blanco, scmbrada de flores de oro, y suelros los cabellos por las espaldas, arrimada á un báculo de negro y finísimo ébano, entró en el aposento de Don Quixote, con cuya presencia turbado y confuso se encogió, y cubrió casi todo con las sábanas y colchas de la cana, muda la lengua, sin que acertase á hacerle cortesía ninguna. Sentósc Altrisidora cn una silla junto á su cabecera, $y$ despues de haber cado un gran suspiro, con voz ticrna y debilitada, le dixo: quando las mugeres principales, $y$ las recatadas doncellas atropellan por la honra, y dan licencia á la lengua que rompa por todo inconveniente, dando noticia en público de los secretos que su corazon encicra, en estrecho término se hallan. Yo, scñor Don Quixote de la Mancha, soy una destas, apretada, vencida y cnamorada; pero con todo esto sufrida $y$ honesta, tanto, que por serlo tanto, reventó mi alma por mi silencio, y perdí la vida. Dos dias ha que la consideracion del rigor con que 
$3^{10}$

DON QUIXOTE DE LA MANCHA

me has tratado ió mas duro que nármol á mis quejas, empedernicto caballero! he estado muerta, ó aloménos juzco visto: y si no fucra porque gada por tal de los que me han visto: yi no fuera porque cl amor, condoliéndose de mí, depositó mi remedio e los martirios deste buen escudero, allá me quedara en el los mano bancho, depootro mundo Bicn pudicra el amor, divo Sancho, depositarlos en ro dígame, scñora, así el Cielo la acomode con otro mas blando amante que mi amo ique es lo que viri en el otro mundo? que hay en el infierno? porque quien muere mundo? aqu hay ch inferno? porquel quicero. Ia desesperado, por fuerza ha de tener aquel paradero. La verdad que os diga, respondió Altisidora, yo no debi de morir del todo, pues no entré en el inficrno, que si llí entara una por una no pudiera salir dél, aunque alla cnera una por una no puéć sa puerta adonde adonde estaban jugando hasta una docena de diablos á la pelota, todos en calzas y en jubon, con valonas guarnecidas con puntas de randas flamencas, y con unas vueltas de lo puntas de randas flariencas, y con un puatro dedos de parciesen las manos mas la brazo de fucra, porque parcciesen las manos mas largas, en las quales tenian unas palas de fuego: y lo que mes admiró fué, que les servian en lugar de pelotus libros a parecer llenos de viento y de borra, cosa maravillosa y nueva; pero esto no me admiró tanto, como cl ver, que sicndo natural de los jugadores el alegrarse los gananciosos, y entristccerse los que pierden, allí en los aquel juego todos grunian, todos regandí Sancho, pormaldecian. Eso no es maravilla, respondió Sancho, porque los diablos jueguen, ó no jueguen, nunca pueden estar contentos, ganen, ó no ganen. Así debe de ser, respondió Alrisidora, mas hay otra cosa, que tambien me
PARTE TT. CAPITUOOXX. 3 II admira (quicro decir me admiró entónces) y fué, que al primer bolco no quedaba pelota en pic ni de prove cho para scrvir otra vez, y así menudeaban libros nuevos y vicjos, que cra una maravilla. $\dot{A}$ uno dellos, nuevo flamante $y$ bien cncuadernado, le diéron un papirotazo, que le sacíron las tripas, y le esparciéron las hojas. Divo un diablo í otro: mirad que libro cs ese, y el diablo le respondió : esta es la Seranda Parte de la Historica de Don Onixote de la Mancha, no compuesta por Cide Hamete su primer autor, sino por un Aragones, que el diec ser natural de Tordesíllas. Quitádmele de ahí, respondió el otro diablo, y metedle en los abismos del infierno, no le vean mas mis ojos. ¿Tan malo es? respondió el otro. Tan malo, replicó el primero, que si de propósito yo mismo me pusicra á haccrle peor, no acertara. Prosiguićron su juego, pelotcando otros libros, y yo por haber oido nombrar á Don Quixore , á quien tanto aciamo y quicro, procuré que se me quedise cn la memoria esta vision. Vision debió de ser sin duda, dixo Don Quixote, porque no hay otro yo en el mundo, y ya esa historia anda por acá de mano en mano, pero no para en ninguna, porque todos la dan del pic. Yo no me he alterado en oir que ando como cucrpo fantístico por las tinicblas del abismo, ni por la claridad de la ticrra, porque no soy aquel de quien csta historia trata. Si ella fuere buena, ficl y verdadera, tendrá siglos de vida, pero si fuere mala, de su parto á la sepultura no scrá muy largo cl camino. Iba Altisidora á proseguir en quejarse de Don Quixore, quando le dixo Don Quixote: muchas veces os he dicho, scñora, que á mí me pesa de que hayais colocado en mi vuestros pensamien- 
tos pucs de los mios ántes pueden ser agradecidos que ro ser de Dulcinea del Toboso, y los hados, si los hubiera, me dedicáron para ella, y y los hados, si los hubiera, me ha de ocupar cl lugar pensar que otra alguna hermosura ha de ocupar cl lugar que en mi alma ticne, es pensar lo imposible. Suficiente desengaño es este, para que os retireis en los límites de vucsua he puede obligar á lo imvucstra honcticad, pues nadic se pucde obligar á lo imposible. Oycndo lo qual Altisidora, mostrando cnojarse y alterarse, le diso : vive el Scñor, Don bacallao, alma de almircz, cuesco de dátil, mas terco y duro que villano rogado quando tiene la suya sobre cl hito, que si arremeto á vos, que os tengo de sacar los ojos. ¿ Pensais por ventura, Don vencido, y Don molido á palos, que yo me he muerto por vos? Todo lo que habeis visto esta yo me he muerto por vo muger, que por noche ha sido fngico, que no soy yo muger, que por semejantes camellos habia de dexar que me doliese un negro de la uńa, quanto mas morirme. Eso creo yo muy bien, dixo Sancho, que cito del morirse los enamorados, bs créalo Júdas. Estando en estas pláticas entró el músico cantor y pocta, que habia cantado las dos ya referidas estancias, el qual haciendo una gran reverencia á Don Quixore, divo: vuesa merced, scñor caballcro, me cuenQ y te $\mathrm{y}$ tenga en cl numero de sus mayores servidores, porque ha muchos dias, que le soy muy aficionado, así por su fama, como por sus hazañas. Don Quixote le respondió vuesa merced me diga quien es, porque mi cortesía respond á sus merecimientos. El mozo respondió que era e ponda a sus merecimientos. El mozo resp por querto músico y panegírico de la noche ántes. Por cicrto, replicó Don Quixote, que vuesa merced tiene extremada voz; pero lo que cantó no me parece que fué muy á pro-
PARTEII. CAPÍTULO IXX.

pósito, porque : que tienen que ver las estancias de Garcilaso con la mucrte desta señora? No se maraville vuesa merced deso, respondió el músico, que ya entre los intonsos poctas de nuestra edad se usa que cada uno escriba como quisiere, y hurte de quien quisiere, venga, ó no venga á pelo de su intento, $y$ ya no hay necedad, que canten, ó escriban, que no se atribuya á licencia poética. Responder quisiera Don Quixote, pero estorbúronlo el Duque y la Duquesa, que entráron á verle, entre los quales pasáron una larga y dulce plática, en la qual dixo Sancho tantos donayres y tantas malicias, que dexáron de nuevo admirados á los Duques, así con su simplicidad, como con su agudeza. Don Quixote les suplicó le diesen licencia para partirse aquel mismo dia pues á los vencidos caballeros como él , mas les convenia habitar una zahurda, que no Reales Palacios. Dićronsela de muy bucna gana, y la Duquesa le preguntó, si quedaba en su gracia Altisidora. El le respondió: señora mia, sepa Vuestra Señoría que todo el mal desta doncella nace de osiosidad, cuyo remedio es la ocupacion honesta y continua. Ella me ha dicho aquí que se usan randas en el infierno, y pues clla las debe de saber hacer, no las dexe de la mano, que ocupada en menear los palillos no se menearán en su imaginacion ia imágen, ó imágines de lo que bien quiere: $y$ csta es la verdad, este mi parecer, $y$ este es mi conscio. Y il mio, añadió Sancho, pues no he visto en toda mi vida randera que por amor se haya muerto: que las doncellas ocupadas mas ponen sus pensamientos en acabar sus tareas, que en pensar en sus amores. Por mí lo dico, pucs mientras estoy cavando no me acuerdo de mi oislo, diso de mi Tcresa Panza, á quien quicтом. Iv. 
so mas que á las pestañas de mis ojos. Vos decis muy bien, Sancho, dixo la Duquesa, y yo haré que mi Altisidora se ocupe de aquí adelante en hacer alguna labos blanca, que la sabe hacer por extremo. No hay para que, señora, respondio Altisidora, usar dese remedio, pues la consideracion de las crueldades que conmigo ha usado este malandrin mostrenco, me le borrarán de la memoria sin otro artificio a!guno, y con licencia de vuestra rrandeza me quicro quirar de aquí, por no ver delante de mis ojos, ya no su triste figura, sino su fea y abominable catadura. Eso me parece, dixo cl Duque , á lo que sucle decirse, que aquel que dice injurias, cerca csta de perdonar. Hizo Alrisidora muestra de limpiarse las lúgrimas con un panuelo, $y$ haciendo reverencia á sus senores, se salió del aposento. Mándore yo, dixo Suncho, pobre doncella, mándote, digo, mala ventura, pues las has habido con un alma de esparto, y con un corazon de encina : í fe que si las hubieras conmigo, que otro gallo te cantara. Acabóse la plática, vistióse Don Quixote, comió con los Duques, y partióse aquella tarde.

\section{CAPITULO IXXI.}

De lo que á Don Ouixote le sucedió con su escudero Sancho, yendo á sin aldea.

Iba cl vencido y asendereado Don Quixote pensativo ademas por una parte, y muy alegre por otra. Causaba su tristeza el vencimiento, y la alegría el considerar en la virtud de Sancho, como lo habia mostrado en la resurecion dr. Altisidora, aunque con algun escrúpulo se persuadia á que la cnamorada doncella fuese muerta
PARTEIT. CAPITULO LXXT.

de véras. No iba nada alegre Sancho, porque le cntristecia ver que Altisidora no le habia cumplido la palabra de darle las camisas, y vendo y vinienio en esto, di xo á su amo: en verdad, señor, que soy cl mas desgraciado médico que se debe de hallar en el mundo, en el qual hay fisicos que con matar al enfermo que curan, quieren ser pagados de su trabajo, que no es otro, sino firmar una cedulilia de algunas medicinas, que no las hace él, sino cl boticario, y cútalo cantusado y á mí, que la salud agena me cuesta gotas de sangre, mamonas, pellizcos, alfilerazos $y$ azotes, no me dan un ardite: pues yo les roto á tal, que si me traen í las manos otro algun enfermo, que ántes que le cure me han de untar las mias, que el Abad de donde canta yanta, y no quicro creer que me haya dado el Ciclo la virtud que tengo, para que yo la comunique con otros de bóbilis bóbilis. Tú cienes razon, Sancho amigo, respondió Don Quixote, y halo hecho muy mal Altisidora en no haberte dado las prometidas camisas, y puesto que tu virtud es gratis data, que no te hal costado estudio alguno, mas que curudio es recibir martirios en tu persona: de mi te sé secir, que si quisieras paga por los azotes deI desencanto de Dulcinea, ya te la hubiera dado tal como buena; pero no se si vendrá bien con la cura la paga, y no querria que impidiese el premio á la medicina. Con todn cso me parece que no se perderí nada en probarlo: mira, Sancho, cl que quicres, $y$ azótate luego, y púgate de conta do, $\mathrm{y}$ de ru propia mano, pues tienes dineros mios. A cuyos ofrecimientos abrió Sancho los ojos y las orejas de un palmo, y dió consentimiento en su corazon á azotarse de buena gana, y dixo á su amo: agora bien, seinor, yo rim. iv. 
quicro disponerme á dar gusto í vuesa mereed en lo que desea, con provecho mio: que el amor de mis hijos $y$ de mi muger, me hace que me muestre interesado. Dí game vuesa merced quanto me dará por cada azote que me diere. Si yo te hubicra de pagar, Sancho, respondió Don Quixote, conforme lo que mereec la grandeza y calidad deste remedio, el tesoro de Venecia, las minas del Potosí fucran poco para pagarte : toma tú el ticnto á lo que llevas mio, y pon el precio á cada azote. Ellos, respondió Sancho, son tres mil y trecientos y tantos: de ellos me he dado hasta cinco, quedan los demas: entren entre los tantos estos cinco, y vengamos á los tres mil y trecientos, que á quartillo cada uno, que no llevaré ménos si todo el mundo me lo mandase, montan tres mil y trecientos quartillos, que son los tres mil, mil y quinientos medios reales, que hacen setecientos $y^{\prime}$ cinqü̈enta reales, $y$ los trecientos, hacen ciento y cinqü̈enta medios reales, que vienen á lacer setenta y cinco reatles, que juntándose á los setecientos y cinqüenta, son por todos ochocientos y veinte y cinco reales. Estos desfalcaré yo de los que tengo de vuesa merced, y entraré ell mi casa rico y contento, aunque bien azotado, porque no sc toman truchas... y no digo mas. i Sincho bendito! ¡O Sancho amable! respondió Don Quixote, $y$ quan obligados hemos de quedar Dulcinea, y yo á servirte todos los dias que el Ciclo nos diere de vida. Si clla vuelve al ser perdido (que no es posible sino que vuclva) su desdicha habrí sido dicha, y mi vencimiento felić́simo triunfo: y mira Sancho, quando quicres comenzar la diciplina, que porque la abrevies te añado cien realcs. ¿Quando? replicó Sancho, esta noche sin falta: procure vuesa merced que la tengamos cn el campo al ciclo abierto, que yo me abriré mis carnes. Llegó noche esperada de Don Quixote con la mayor ansia del mundo, pareciéndole que las ruedas del carro de Apolo sc habian qucirado, $y$ que el dia se alargaba mas de lo acostumbrado, bien así como acontece á los cnamora dos, que jamas ajustan la cuenta de sus descos. Finalmente se entráron entre unos amenos árboles, que poco desviados del camino estaban, donde devanto vacías la silla y albarda de Rocinante y el rucio, se tendiéron sobre la verde yerba, y cenúron del repuesto de Sancho, el qual haciendo del cabestro y de la xáquima del ru cio un poderoso y flexíbile azore, se reciró hasta veinte pasos de su amo entre unas hayas. Don Quivote que le vió ir con denuedo, y con brio, le dixo : nira, anigo, que no te hagas pedazos, da lugar que unos azotes aguarden á otros, no quicras apresururte tanto cn la carrera, que cn la mitad della te falte el aliento, quicro decir, que no te des tan recio, que te falte la vida ántes de $11 \mathrm{cgar}$ al númcro descado, y porque no pierdas por carta de mas, ni de ménos, yo estaré desde á parre contando por este mi rosario los azotes que te dieres. Favorézcate cl Cielo conforme tu buena intencion merece. Al buen pagador no le duelen prendas, respondió Sancho, yo pienso darme de menera, que sin matarme, me ducla, que en csto debe de consistir la sustancia deste milagro. Desnudóse luego de medio cuerpo arriba, y arrebatando el cordel comenzó á darse, y comenzó Don Quivore í contar los azores. Hasta scis, ó ocho se habria dado Sancho, quando le parcció ser pcsada la burla, y muy barato el precio dellia, y deteniéndose un poco, diso á su amo, 
que se llamaba á engaño, porque merecia cada azote de quellos ser pagado í medio real, no que á quartillo. Prosigue, Sancho amigo, y no desmayes, le dixo Don Quixote, que yo doblo la parada del precio. Dese modo, dixo Suncho, á la mano de Dios, y lluevan azotes pero el socarron dexó de dárselos en las espaldas, y dapero en soch unos suspiros de quando en quando , que parcin que con cada uno dellos se lo arrancodo, que parceir que con cada uno dellos se lo arranca ba el alma. Tierna la de Don Quixote, temeroso de que no se le acabase la vida, y no consiguiese su deseo por la imprudencia de Sancho, le dixo : por tu vida, amigo, que se quede en este punto este negocio, que me parece muy áspcra esta medicina, y scrá bien dar tiempo al tiempo que no se ganó Zamora en un hora. Mas de mil azotes, si yo no he contado mal, te has dado, bastan por agora, que el asno, hablando á lo groscro, sufre la carca, mas no la sobrecarga. No, no, señor, respondió Sancho, no se ha de decir por mi : á dineros parajos brazos quebrados: apártese vuesa merced otro pogatos brazos quebros: aphil azotes siquiera que á dos co, y déxeme dar otros mil azotes siquiera, que a dos levadas destas habrémos cumplido con esta partida, y aun nos sobrarí ropa. Pues tú te hallas con tan buena disposicion, dixo Don Quixote, el Cielo te ayude, y pégate, que yo me aparto. Volvió Sancho á su tarea, con tanto denuedo, que ya habia quitado las cortezas á muchos árboles: tal era la riouridad con que se azotaba : y alzando una rez la roz, $y$ dando un desaforado azote en una haya, dixo: áf morir Sanon, y quantos con ćl son. Acudio Don Quixore luego al son de la lastimada voz y del golpe del riguroso azote, y asicndo del torcido cabestro, que le servia de corbacho á Sancho, le dixo: no permita la
PARTE IY. CARÍTULO IXXI.

la suerte, Sancho amigo, que por el gusto mio picrdas tú la vida, que ha de servir para sustentar á tu muger, y á tus hijos: espere Dulcinea mejor coyuntura, que yo me contendré en los límites de la esperanza propínqua, y esperaré que cobres fuerzas nuevas, para que se concluya este negocio á gusto de todos. Pues ruesa merced, senor mio, lo quicre así, respondió Sancho, sca en buena hora, $\mathrm{y}$ écheme su ferreruelo sobre estas espaldas, que estoy sudando, y no querria resfriarme, que los nuevos diciplinantes corren este peligro. Hizolo así Don Quixotc, y quedándose en pelora, abrigó á Sancho, cl qual se durmió hasta que le despertó el sol, y luego volviéron á proseguir su camino, á quien dićron fin por entónces en un Lugar que tres leguas de allí estaba. Apcúronse en un meson, que por tal le reconoció Don Quixote, y no por castillo de cava honda, torres, rastrillos y puente levadiza: que despues que le venciéron, con mas juicio cn todas. las cosas discurria, como agora se dirá. Alojáronle en una sala baxa, á quicn servian de guadameciles unas sargas viejas pintadas, como se usa en las aldeas. En una dellas estaba pintado de malísima mano el robo de Elena, quando el atrevido huésped se la llevó á Mcnelao, y en otra estaba la historia de Dido y de Enéas, ella sobre una alta torre, como que hacia de señas con una media sábana al fugitivo huésped, que por el mar sobre una fragata, ó bergantin se iba huyendo. Notó en las dos historias, que Elena no iba de muy mala gana, porque se reia á socapa y á lo socarron; pero la hermosa Dido mostraba verter lágrimas del tamaño de nueces por los ojos. Viendo lo qual Don Ouixote, dixo: cstas dos señoras fućron desdichadísimas, por no haber na- 
$3^{20}$

DON QUTXOTE DE LA MANCHA

cido en esta edad, $y$ yo sobre todos desdichado, en no haber nacido en la suya, pues si yo encontrara aquestos señores, ni fucra abrasada Troya, ni Cartago destruida, pues con solo que yo matara á Páris, se excusaran tantas desgracias. Yo apostaré, dixo Sancho, que ántes de mucho tiempo no ha de haber bodegon, venta, ni meson, ó tienda de barbero, donde no ande pintada la historia de nuestras hazañas; pero querria yo que la pintasen manos de otro mejor pintor, que el que ha pintado á estas. Tienes razon, Sancho, dixo Don Quixote, porque cste pintor es como Orbaneja, un pintor que estaba en Úbeda, que quando le preguntaban, que pintaba, respondia: lo que salice, y si por ventura pintaba un gallo, escribia debaxo: Este es gallo, porque no pensasen que cra zorra. Desta manera me parcce á mí, Sinncho, que debe de ser el pintor, ó escritor, que todo es uno, que sacó á luz la historia deste nuevo Don Quixote que ha salido, que pintó ó escribió lo que saliere, ó habrá sido como un poeta, que andaba los años pasados en la Corte llamado Mauleon, el qual respondia de repente á quanto le preguntaban, y preguntándole uno a que queria decir Deum de Deo? respondió: dé donde dicre. Pero dexando esto á parte, dime si piensas, Sancho, darte otra tanda csta noche, $y$ si quicres que sea debaxo de techado, ó al ciclo abierto. Pardiez, scñor, respondio Sancho, que para lo que yo pienso darme, eso se me da en casa, que en el campo ; pero con todo eso querria que fuese entre árboles, que parece que me acompañan, y me ayudan á llevar mi trabajo maravillosamente. Pues no ha de ser así, Sancho amigo, respondió Don Quixote, sino que para que tomes fuerzas lo hemos de
PARTEIT. CAPÍTULO LXXI.

guardar para nuestra aldea, que á lo mas tarde llegrarémos allá despues de mañana. Sancho respondió, que hicicse su gusto; pero que él quisiera concluir con brevedad aquel negocio á sangre caliente, y quando estaba picado el molino, porque cn la tardanza suele estar muchas veces el peligro, y á Dios rogando, y con el mazo dando, y que mas valia un toma, que dos te daré, y el páxaro en la mano, que el buytre volando. No mas refranes, Sancho, por un solo Dios, dixo Don Quixote, que parece que te vuelves al sicut erat: habla á lo llano á ln liso, á lo no intricado, como muchas veces te he dicho, $y$ verís como te vale un pan por ciento. No sé que mala ventura es esta mia, respondió Sancho, que no sé decir razon sin refran, ni refran que no me parezca razon; pero yo me cmendaré, si pudicre, y con esto cesú por entónces su piática.

\section{CAPÍTULO LXXII.}

De como Don Quixote y Sancho llegáron á su aldea. Todo aquel dia, esperando la noche, estuviéron en aquel Lugar y meson Don Quixote y Sancho, el uno para acabar en la campaña rasa la tanda de su diciplina, y el otro para ver el fin della, en el qual consistia el de su desco. Llegó en esto al meson un caminante á caballo, con tres, ó quatro criados, uno de los quaies dixo al que cl señor dellos parecia: aquí puede vuesa merced, scñor Don Álvaro Tarfe, pasar hoy la siesta : la posada parece limpia y fresca. Oyendo esto Don Quixote ${ }^{\circ 1}$, le dixo á Sancho: mira Sancho, quando yo hojece aquel libro de la segunda parte de mi historia, me parece que de rom. $1 v$. 
pasada topé allí este nombre de Don Álvaro Tarfe. Bien podrá ser, respondio Sancho, dexémosle apear, que despues se lo prequntarémos. El caballero se apcó, y fronpue de Don Quixore, la huéspeda le dió tcro del upascrto de Don Quixore, la hespeda 10 una sula baxa, crjaczada con orras pintadas sargas, como las que tenia la cstancia de Don Quixote. Púsose el recien venido caballero á lo de verano, y caliéndose al porra del meson, que cra espacioso y fresco, por el qual portal del pande bucno camina ruesa nereed, señor gentilhombre? I Don Quixote le respondió : á una aldea que está aquí cerca, de donde soy natural. Y vuesa merced :donde camina? Yo, scinor respondió el caballero, voy á Granada, que es mi patria. Y buena patria, replicó Don Quixote : pcro dígame vuesa merced por cortesía su nombre, porque me parcec que me ha de importar saberlo, mas de lo que buenamente podré decir. Mi nombre es Don Alvaque bucnamente pó decir Quixote: sin duda alguna pienso que vuesa mereed debe de ser aquel Don Álvaro Tarfe que anda impreso en la segunda parte de la historia de Don Quixote de la Mancha, recien impresa, y dada á la luz del mundo por un autor moderno. El mismo soy, respondió el caballero, y el tal Don Quixote, sugeto principal de la tal historia, fué grandísimo amigo mio, y yo fuí el que le sacó de su ticrra, ó aloménos le moví que viniese á unas justos que se hacian en Zaragoza, adonde yo iba, y en verdad, en verdad que le hice muchas amistades, y que le quité de que no le palmease las espaldas el verdugo, por ser demaiadomente atrevido. $Y$ dígame vuesa merced, señor Don Álvaro ; parezco yo en allgo á ese tal Don
PARTEIT. CAPÍTULO LXXIT.

Quixote que vuesa merced dice? No por cicrto, respondió el huésped, en ninguna manera. Y ese Don Quixote, dixo el nuestro : traia consigo á un escudero llamado Sancho Panza? Sí traia, respondió Don Álvaro, y aunque tenia fama de muy gracioso, nunca le oí decir gracia que la tuviese. Eso creo yo muy bien, dixo á esta sazon Sancho, porque cl decir gracias, no cs para todos, y cse Suncho que vuesa merced dice, scñor gentilhombre, debe de ser algun grandísimo bellaco, frion, y ladron juntamente, que el verdadero Sancho Panza soy yo, que tengo mas gracias que llovidas, y si no, haga vuesa merced la experiencia, $y$ ándese tras de mí por lo ménos un año, y verá que se me caen á cada paso, $y$ tales $y$ tantas, que sin saber yo las mas veces lo que me digo, hago reir á quantos me escuchan: y el verdadero Don Quixote de la Mancha, el famoso, ol valientc $y$ el discreto, el cnamorado, el desfacedor de agravios, el tutor de pupilos y huérfanos, el amparo de las viudas, el matador de las doncellas, el que tiene por única Señora á la sin par Dulcinea del Toboso, es este señor que cstá presente, que es mi amo: todo qualquier orro Don Quixate, y qualquier orro Sancho Panza, es burlería , y cosa de sueño. Por Dios que lo creo, respondió Don Alvaro, porque mas gracias habeis dicho vos, amigo, en quatro razones que habeis hablado, que el otro Sancho Panza en quantas yo le oí hablar, que fuéron muchas. Mas tenia de comilon, que de bien hablado, y mas de tonto, que de gracioso, y tengo por sin duda, que os encantadores que persiguen á Don Quixote el bueno, han querido perseguirme á mí con Don Quixote el malo. Pero no sé que me diga, que osaré yo jurar que le dexo rom. IV 
metilo en la casa del Nuncio en Toledo, para que le curen, y arora remancce aquí orro Don Quixote, aun-

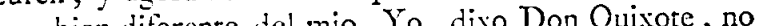
sé si soy bueno; pero sé decir, que no soy el malo: para prueba de lo qual quiero que sepa vuesa mereed, mi señor Don Alvaro Tarfe, que en todos los dias de mi iida no he cstado en Zaragoza, ántes por habcrme dicho, que ese Don Quixote fantástico se liabia hallado en las justas desa ciudad, no quise yo entrar en clla, por sacar í las barbas del mundo su mentira, y así me pasé de claro á Barcelona, archivo de la cortesía, albergue de los extrangeros, hospital de los pobres, patria de los valientes, venganza de los ofendidos, y correspondencin grata de firmes amistades, $y$ cn sitio y en belleza único $\mathrm{Y}$ aunque los sucesos que cn clla me han sucedido no son de mucho gusto, sino de mucha pesadumbre, los llevo sin clla, solo por haberla visto. Finalmente, señor Don Álvaro Tarfe, yo soy Don Quixote de la Mancha, el mismo que dice la fama, y no ese desventurado, que ha querido uisurpar mi nombre, $y$ honrarse con mis pensamientos. Á vuesa merced suplico, por lo que debe á scr caballero, sca servido de hacer una declaracion ante el Alcaldc deste Lugar, de que ruesa merced no me ha visto en todos los dias de su vida hasta agora, y de que yo no soy el Don Quixote impreso en la scyunda parte, wi este Sancho Panza mi escudero es aquel que vuesa mer ced conoció. Eso haré yo de muy buena gana, respondió Don Alvaro, puesto que cause admiracion ver dos Don Quixotes, y dos Sanchos á un mismo ticmpo, tan conformes en los nombres, como diferentes en las acciones: y vuelvo á decir, y me afirmo, que no he visto lo que
PARTEYT. CAP'TUIO IXXII.

he visto, ni ha pasado por mí lo que la pasado. $\mathrm{Sin}^{325}$ da, dixo Sancho, que vuesa merced debo de estor sin dutado, como mi Señora Dulcinea " del Toboso , y pluguiera al Cielo que estuvicra su descneanto de vuesa merced en darme otros tres mil y tantos azotes como me doy por ella, que yo me los diera sin interes alouno. No entendo eso de azotes, dixo Don Álvaro: y Sancho le respondió, que era largo de contar; pero que él se lo contaria si acaso ibian un mesmo camino. Llegŕse en csto la hora de comer, comiéron juntos Don Quixote y Dun Álvaro. Entró acaso el Alcalde del pueblo en el meson con un escribano, ante el qual Alcalde pidió Don Quixote por una peticion, de que á su derecho convenia, de que Don Alvaro Tarfe, aquel caballero que allj estaba presente, declarase ante su merced, como no conocia á Don Quixote de la Mancha, que asimismo estaba allí presente, y que no tra aquel que andaba impreso en una histcria intitulada: Segzindaz Parte de Don (Onixote de la Mancha, compnesta por an tal di Avellaneda, natural di Tordesillas. Finalmente el Alcalde proveyó jurílicamente: la declaracion se hizo con todas las fuerzas que en tales casos debian hacerse, con lo que quedáron Don Quixote y Sancho muy alegres, como si les importara mucho semejante declaracion, $y$ no mostrara claro la diferencia de los dos Don Quixotes, $y$ la de los dos Sanchos, sus obras y sus palabras. Muchas de cortesías y ofrecimientos pasáron cntre Don Alvaro y Don Quixote, en las quales mostró el gran Manchego su discrecion, de modo, que desenganó á Don Álvaro Tarfe del crror en que estaba, cl qual se dió á entender que debia de cstar encantado, pues tocaba con la mano dos tan contra- 
ros Don Quixotes. Llego la tarde, partieronse de aquel Lugar, y á obra de media legua se apartaban dos caminos diferentes, el uno, que guiaba á la aldea de Don Quivore y loro el que habia de llevar Don Alvaro. Quixote, y el otro, el que hab de llevar Don Alvaro. En este poco espacio le contó Don Quixote la desgracia de su vencimiento, y cl encanto, y el remedio de Dulcinea, que todo puso en nueva admiracion á Don Alvaro, el qual qucrodo puixote y á Sancho, siquió su camino, abrazando a Don Quixore y a Sancho, sighio su camino, y Don Quixote el suyo, que aquella noche la pasó entre orros árboles, por dar lugar á Sancho de cumplir su penitencis, que la cumplió del mismo modo que la papertezas de las hayas, harto mas arda suardó tanto, que no pudicque de sus espaldas, que mosca, aunque la tuvicra encimo perdió el engañado Doin Quivote un solo golperiso el chań que con los de la noche pasa pe de la cuenta, y hallo, que con los de la noche pasada eran tres mil y veinte $y$ nueve. Parce que habia madrugado el sol á ver el sacrificio, con cuya luz volvićron proseguir su camino, tratando cntre los dos del veron á engaño de Don $A$ lvaro, y de quan bien acordado habia sido tomar su declaracion ante la Justicia, y tan auténticamente. Aquel dia y aquella noche caminúron sin sucederles cect contento sobre modo, y esperaba el dia, por ver si en el camino topaba ya descncantada á Dulcinea su Señora, y siguiendo su comino, no topaba muger ninguna, que no ín á porer mentir las promesas de Merlin. por infalible no poder mentir las promesas de Merlin. Con estos pensamientos y descos subiéron una cuesta ar riba, desde la qual descubriéron su aldea, la qual vista de Sancho, se hincó de rodillas, $y$ dixo : abre los ojos, deseada patria , y mira que vuelve á ti Sancho Panza tu hijo, si no muy rico, muy bien azotado. Abre los brazos, y recibe tambien tu hijo Don Quixote, que si viene vencido de los brazos agenos, viene vencedor de sí mismo, que segun él me ha dicho, es el mayor vencimiento que desear se puede. Dineros llevo, porque si buenos azotes me daban, bien caballero me iba. Déxate desas sandeces, dixo Don Quixote, y vamos con pie derecho á cntrar en nuestro Lugar, donde darémos vado á nuestros ima ginaciones, y la traza que en la pastoral vida pensamos exercitar. Con esto baxáron de la cuesta, y se fuéron : su pucblo.

\section{CAPITULO LXXIII}

De los agiteros que tuvo Don Ouixote al entrar de sib aldia, con otros sucesos que adornan y acreditan esta grande historia.

A la cntrada del qual, segun dice Cide Hamete, vió Don Quixotc, que en las eras de! Lugar estaban rinendo dos mochachos, y el uno dixo al otro: no te canses Periquillo, que no la has de ver en todos los dias de tu vida. Oyólo Don Quivote, y divo á Sancho: : no adviertes, amigo, lo que aquel mochacho ha dicho, no la has de ver en todos los dias de tu vida? Pues bien : que importa, respondió Sancho, que haya dicho eso el mochacho? QQue? replicó Don Quivore ¿no ves tú que aplicando aquella palabra á mi intencion, quicre significar, que no tengo de ver mas á Dulcinea? Queríale responder Sancho, quando se lo estorbó ver, que por aquella campaña venia huyendo una licbre seguida de muchos 
328

DON QUIXOTE DE IA MANCHA

galgos y cazadores, la qual temerosa se vino á recoger y á agazpar debaxo de los pies del rucio. Cogióla Sanchó mano salva, y presenróscla á Don Quixote, el qual cho diso: malum signum, malum signum : liebre huye, salgos la siguen Dulcinca no parece. Extrano es vuesa merced, dixo Sancho: presupongamos que esta liebre es Dulcinca del Toboso, y estos galgos que la persiguen son los malandrines encantadores que la transperigu so la la cojo, y la pongo cn poder de vuesa merced que la tiene en sus brazos go cr poder mala señal es esta, ni que mal agüero se puede tomar de aquí? Los dos mochachos de la pendencia llegáron á ver la licbre y al uno dellos preguntó Sancho, que por que reñian. Y fuéle respondido por el que habia dicho: no la verás mas en toda tu vida, que él habia tomado al otro mochacho una jaula de grilios la qual no pensaba volvérsela en toda su vida. Sacó Sancho quatro quartos de la faltriquera, y dióselos al mochacho por la jaula, y púsosela en las manos á Don Quixote, diciendo: he aquí, scñor, rompidos y desbaratados estos a ücros, que no tienen que ver mas con nuestros sucesos scgun que yo imagino, aunque tonto quc con las nubes de antaño: y si no me acuerdo mal, he oido decir al Cura de nuestro puchlo, que no es de personas christianas, ni discretas, mirar en cstas ninerías, $y$ aun ruesa merced mismo me lo divo los dias pasados, díndome a chender, que cran contos todos aquellos christioquellos christianos que miraban en agücros, $y$ no es menester hacer hincapie en esto, sino pasémos adelante, y entrémos en nuestra aldea. Llegáron los cazadores, pidiéron su licbre, y diósela Don Quixote: pasáron adelante, y á la entrada

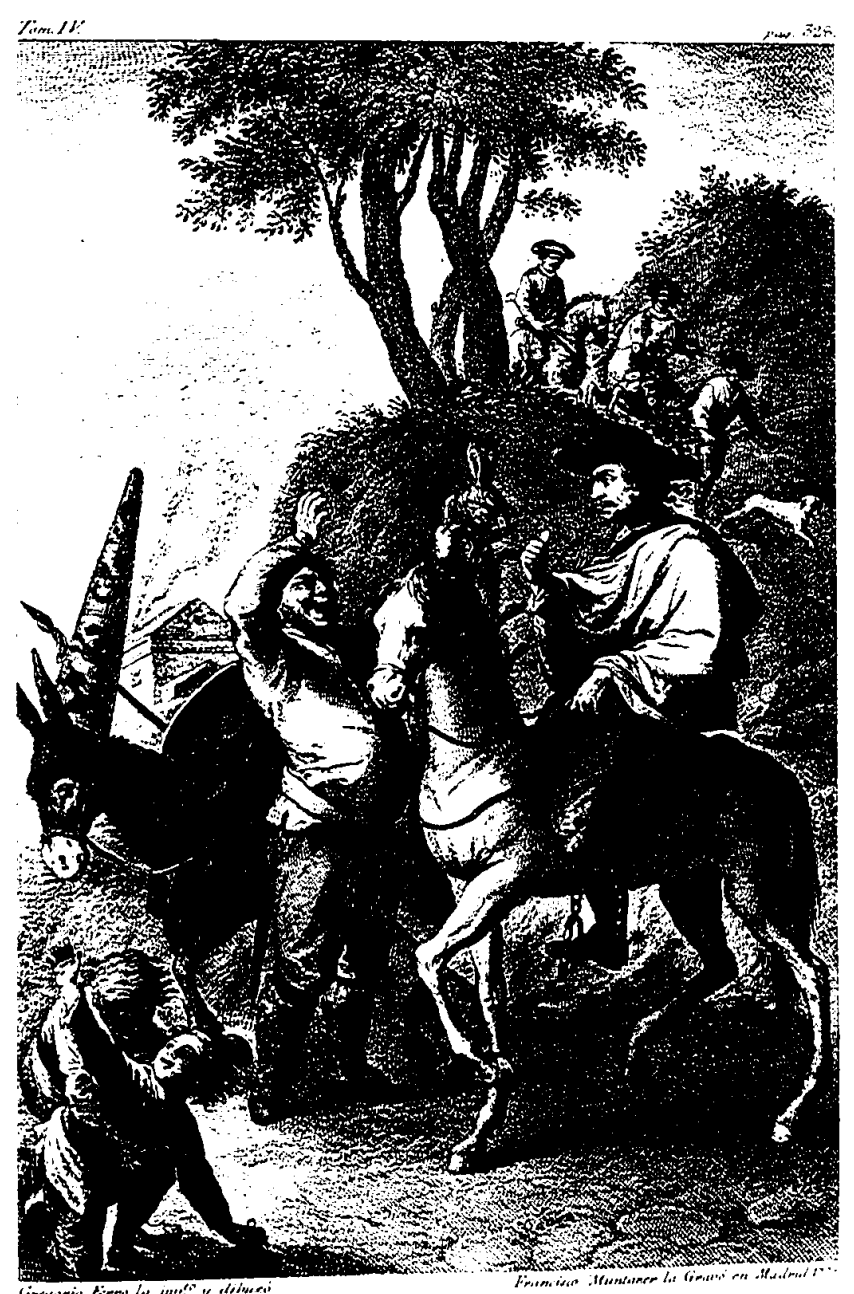


PARTE II. CAPítULO IXXIT.

del pueblo topáron en un pradecillo rezando al Cura $y$ al Bachiller Carrasco. Y es de saber que Sancho Panza habia cchado sobre el rucio y sobre el lio de las armas, para que sirviese de repostero, la túnica de bocací pintada de llamas de fuego, que le vistiéron en el castillo del Duque la noche que volvió en sí Altisidora. Acomodóle tambien la coroza en la cabeza, que fué la mas nueva transformacion y adorno con que se vió jamas jumento en el mundio. Fuéron luego conocidos los dos del Cura y del Bachiller, que se viniéron á ellos con los brazos abiertos. Apcóse Don Quixote, y abrazólos estrechamente, $y$ los mochachos que son linces no excusados, divisúron la coroza del jumento, y acudiéron á verle, y decian unos á otros: venid mochachos, y veréis el asno de Sancho Panza mas galan que Mingo, y la bestia de Don Quixote mas flaca hoy que el primer dia. Finalmente rodeados de mochachos, y acompañados de: $\mathrm{Cu}$ ra y del Bachiller entráron en el pucblo y se fuéron á casa de Don Quixote, y halláron á la puerta della al fima y á su Sobrina, á quien ya habian llegado las nucvas de su venica. Ni mas, ni ménos se las habian dado á $\mathrm{Te}-$ resa lanza, muger de Sancho, la qual desgreñada, y medio desnuda, trayendo de la mano á Sanchica su hija, acudió á ver á su marido, y viéndole no tan bien adclinado, como clla se pensaba que habia de estar un Gohernador, le dixo: ¿como venis así, marido mio, que me parce que venis á pic y despeado, y mas tracis semejanza de desgobernado, que de Gobernador : Calla, Teresa, respondió Suncho, que muchas veces donde hay estacas, no hay tocinos, y vámonos á ne!estra casa, que allá oirás maravillas. Dineros traigo, que es lo que imrom. IV. 
porta, ganados por mi industria y sin daño de nadie. Traed vos dineros mi buen marido, dixo Teresa, y sean Trandos por aquí, ó por allí, que como quicra que los

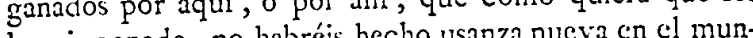
hayais ganado do. Abrazó Sanchica á su padre, y preguntóle si traia algo, que le estaba esperando como el agua de Mayo, y asiéndole de un lado del cinto, y su muger de la mano, tirando su hija al rucio se fućron á su casa, dexando a Don Quixote en la suya en poder de su Sobrina y de su Ama, y en companía del Cura y del Bachiller. Don Quixote, sin guardar términos, ni horas, en aquel mismo punto se apartó á solas con el Bachiller y el Cura y en breves "4 razones les contó su vencimiento, y la obligacion en que habia quedado de no salir de su aldea en un año, la qual pensaba guardar al pic de la letra, sin traspasarla cn ú átomo bicn así como caballero andante, obligado por la puntualidad y órden de la andante caballería, y que tenia pensado de hacerse aquel año pastor, y cntretenerse en la soledad de los campos, donde á rienda suelra podia dar vado á sus amorosos pensamientos, exercitándose en el pastoral y virtuoso exercicio: y que les suplicaba, si no tenian mucho que hacer, y no cstaban impedidos en negocios mas importantes, quisiesen ser sus compañeros, que él compraria ovejas y ganado suficiente , que les diese nombre de pastores: y que les hacia saber, que lo mas principal de aquel negocio estaba hecloo, porque les tenia puestos los nombres que les vendrian como de molde. Díxole el Cura que los dixese. Respondió Don Quixote, que él se habia de llamar el pastor Quixotiz y el Bachiller el pastor Carrascon, y el Cura el pastor Curiambro, y Sancho Panza el pastor
PARTEII. CAPÍTULO LXXII.

Pancino Pasmáronse todos de ver la nueva locura do Don Quixote; pero porque no se les fuese otra $v \mathrm{c} \%$ del pueblo á sus caballerías, esperando que en aquel año podria scr curado, concedićron con su nueva intencion, y aprobíron por discreta su locura, ofreciéndosele por companteros en su excrcicio: y mas, dixo Sanson Carrasco, que como ya todo el mundo sabe, yo soy ceicbérrimo poeta, y á cada paso compondré versos pastoriles, ó corresanos, ó como mas me viniere a cuento, para que nos entretengamos por esos andurriales, donde habemos de andar: y lo que mas es menester, señores mios, es que cada uno escoja el nombre de la pastora que piensa celebrar en sus versos, y que no dexemos árbol por duro que sea, donde no la retule, y grabe su nombre, como es uso y costumbre de Jo cnamorados pastores. Eso está de molde, respondio Don Quixote, puesto que yo estoy libre de buscar nombre de pastora fingida, pues está ahí la sin par Dulcinea del Tuboso, gloria de estas riberas, adomo de estes prados, sustento de la hermosura, nata de los donayres, y finalmente sugeto sobre quien puede asentar bien toda alabanza, por hipérbole que sea. Asi cs verdad, dixo el Cura; pero nosotros buscarémos por ahi pastoras mańcruelas que si no nos quadraren, nos esquinen. $A$ lo que añadió Sanson Carrasco : y quando faltaren, darémoslcs los nombres de las estampadas, é impresas, de quicn está lleno el mundo, Filidas, Amarílis, Dianas, Fléridas, Galateas y Belisardas, que pues las venden en las plazas, bien las podemos comprar nosotros, y tencrlas por nuestras. Si ni dama, ó por mejor decir mi pastora, por ventura se llamare Ana, la celebraré debsexo del nombre de Anarda, y si Francisca, la Hlamaré yo Francenia, y si Tom. iv.
Tr ij 
PARTE II. CAPÍTUIO IXXIV.

Lucia, Lucinda, que todo sc sale alla, y Sancho Panza, si es que ha de entrar en esta cofradía, podrá celchrar a su muger Teresa Panza con nombre de Teresayna. Riósc Don Quixote de la aplicacion del nombre, y el Cura le alabó infinito su honesta y honrada resolucion, $y$ se ofreció de nuevo á hacerle companía todo cl tiempo que le vacase de atender á sus forzosas obligaciones. Con esto se despidiéron dél, y le rogáron y aconsejíron tuviese cuenta con su salud, con regalarse lo que fuesc bueno. Quiso la sucrte que su Sobrina y el Ama oyéron la plírica de los tres, y así como sc fuéron, se entrúron entrúmbas con Don Quixote, y la Sobrina le dixo :que es esto, señor tio? ahora que pensábamos nosotras, que vuesa merced rolvia á reducirse en su casa, y pasar en clla una vida quieta y honrada, se quiere meter en nuevos laberintos, haciéndose pastorcillo? 'Tú que vienes pastorcico, tú que vas, pues en verdad que estí ya duro cl alcacer para zampoñas. $\hat{\Lambda}$ lo que añadió el Ama: ay podrá vuesa mered pasar en el campo las siestas del verano, los serenos del inviemo y al ahullito de los lobos? No por cicito, que este es exercicio y ofic de hombres robustos, curtidos y criados para tal ministerio casi desde las faxas y mantillas: aun mal por mal, mejor es ser caballero andante, que pastor. Mire, señor, tome mi consejo, que no se le doy sobre estar harea de pan y vino, sino en ayúnas, $y$ sobre cincuenta años que tengo de edad : estése en su casa, atienda á su hacienda, conficse á menudo, favorezca á los pobres, y sobre mi ánima si mal le fuere. Callad, hijas, les respondió Don: Quixote, que yo sé bien lo que me cumple. llevadme al lecho, que me parece que no $\mathrm{cs}$ toy muy bueno, y tened por cierto, que ahora sea caballe- ro andante, o pastor por andar, no dexare siempre de acudir á lo que hubiéredes menester como lo veréis por la obra: y las buenas hijas (que lo cran sin duda) Ama y Sobrina, le lievíron á la cama, donde le diéron de comer $y$ regaláron lo posible.

\section{CAPITULO IXXIV.}

De como Don Quixote cayó malo, y del testamento que hizo, y' su nuterie.

Como las cosas humanas no sean cternas, yendo sicmpre en declinacion de sus principius hasta llegar á su último fin, especialmente las vidas de los hombres, y como la de Don Quixote no tuviese privilegio del Cielo para detener el curso de la suya, llegó su fin y acabamiento, quando él ménos lo pensaba, porque o ya fuese de la melincolía, que le causaba el verse vencido, ó ya por la disposicion del Ciclo, que aś́ lo ordenaba, se le arraigo una calentura, que le tuvo scis dias en la cama, en los quales fué visitado muchas reces del Cura, del Bachiller y del Barbero sus amigos, sin quitírsele de la cabecera Sancho Panza su bucn escudero. Estos, creyendo qu la pesadumbre de verse vencido, $y$ de no ver cumplido su desco en la libertad, y desencanto de Dulcinca, le tenia de aquella suerte, por todas las vias posibles procuraban alegrarle, diciéndole el Bachiller que se animase, y levantase para comenzar su pastoral exercicio, para cl qual tenia ya compuesta una écloga, que cicio, para cl qual tenia ya compucsta una ecloga, que ya tenia comprados de su propio dincro dos fumosos per ros pira guardar cl ganado, el uno llamado Barcino y el 
$33+$

DON CUTXOTE DE LA MANCHA

otro Butron, que se los habia vendido un ganadero del Quintanar; pero no por esto dexaba Don Quixote sus tristezas. Llanáron sus amigos al médico, tomóle el puln, y no le contentó mucho, $y$ dixo que por sí, ó por no, atendiese á la salud de su alma, porque la del cucrpo corria peligro. Oyólo Don Quixote con ánimo soseçado; pero no lo oyćron así su Ama, su Sobrina y su escudero, los quales comenzúron á llorar ticrnamente, como si ya le tuvicran muerto delante. Fué cl parecer del médico, que mancolís y desabrimicntos le acababan Rogó Don Quixote, que le dexasen solo, porque queria dormir un poco. Hiciéronlo así, y durmio de un tiron, como dicen, mas de seis horas, tanto, que pensúron el Ama y la Sobrina que se habia de quedar en el sucño. Despertó al cabo del tiempo dicho, y dando una gran voz, dixo: bendito sea el podcroso Dios, que tanto bien me ha hecho. En fin sus misericordias no tienen límite, ni las abrevian, ni impiden los pecodos de los hombres. Estuvo atenta la Sobrina á las razones del tio , y parcciéronle mas concertadas que él solia decirlas aloménos en aquella enfermedad, y preguntóle : que es lo que vuesa merced dice, señor? ? que pecados de los hombres? Las miscricordias, respondió Don Quixote, Sobrina, son las que en este instante ha usado Dios conmigo, á quien, como dixe, no las impiden mis pecados. Yo tengo juicio ya libre y claro sin las sombras caliginosas de la ignorancia, que sobre él me pusiéron mi amarga y continua leyenda de los detestables libros de las caballerías. Ya conozco sus disparates y sus cmbelccos, $y$ no me pesa, sino que este desengano ha llerado tan tarde, que no me dexa tiempo para hacer al-
PARTEII. CAPITULO LXXIV.

guna recompensa, leyendo otros, que sean luz del alma Yo me sicnto, Sobrina, á punto de muerte, querria hacerla de tal modo, que diese á cntender, que no habia sido mi vida ran mala, que dexase renombre de loco : que puesto que lo he sido, no querria confirmar esta verdad en mi muerte. Llámame, amiga, á mis buenos amigos el Cura, el Bachiller Sanson Carrasco, y á Macse Nicolas el Barbero, que quiero confesarme y hacer mi testamento. Pcro deste trabajo se excusó la Subrina con Ia entrada de los tres. A pénas los vió Don Quixote, quando dixo: dadme albricias, buenos señores, de que ya yo no soy Don Quixore de la Mancha, sino Alonso Quixano á quien mis costumbres me diéron renombre de Bueno. $\mathrm{Ya}$ soy enemigo de Amadis de Gaula y de toda la infinita caterva de su linage: ya me son odiosas todas las historias profanas de la andante caballería: ya conozco mi necedad, y el peligro en que me pusiéron haiserlas leido : ya por miscricordia de Dios, escarmentancio en cabcza propia, las abomino. Quando esto le oyéron ciccir los tres, creyéron sin duda que alguna nueva locura le habia tomadio. Y Sanson lc dixo : ahora, señor Don Quixote, que tenemos nueva que estí descreantada la Señora Dulcinea, salc vucsa merced con esto, y agora que estamos tan á pique de ser pastores, para pasar cantando la vida como unos Príncipes, quiere vuesa merced hacerse ermitanio? Calle por su vida, vicelva en sí, y déxese de cuentos. Los de hasta aquí, replicó Don Quixote, que han sido verdadcros en mi daño, los ha de volver mi muerte con ayuda del Cielo en mi provecho. Yo, señores, siento que me voy muriendo à toda priesa, déxense burlas á parte, y tríiganme un confesor que me con- 
$33^{6}$

DON QUIXOTE DE IA MANCHA

fiese $y$ un escribano, que haga mi testamento, que en tales trances como este, no se ha de burlar el hombre con el alma : y así suplico, que en tanto que el señor Cura me confiesa, vayan por el escribano. Mirúronse unos á otros admirados de las razones de Don Quixote, y aunque en duda, le quisiéron crecr, $y$ una de las scñales por donde conjeturáron se moria, fué cl haber vuclto con tanta facilidad de loco á cuerdo, porque á las ya dichas razones a nadió otras muchas tan bien dichas, tan christianas, y con tanto concierto, que del todo les vino á quinas, y con tanto concierto, que del todo creer que cstaba cuerdo. Hizo salir la tar la duda, y á creer que cstaba cuerdo. Hizo salir la Bachiller fué por el escribano, y de allí á poco volvió con él, y con Sancho Panza, el qual Sancho (que ya sabia por nuevas del Bachiller en que estado estaba su senor) hallando á la Ama y á la Sobrina llorosas, comenzó á hacer pucheros y á derramar lágrimas. Acabóse la confesion, y salió el Cura diciendo: verdaderamente se muere, y verdaderamente está cucrdo Alonso Quixano el Bucno, bien podémos entrar para que haga su testamento. Estas nuevas diéron un terrible empujon á los ojos preñados de Ama, Sobrina y de Sancho". Panza su buen escudiero, de tal manera, que los hizo reventar las lágrimas de los ojos, y mil profundos suspiros del pecho, porque verdaderamente, como alguna vez se ha dicho, en tanto que Don Quirote fué Alonso Quivano el Bueno á secas, y en tanto que fué Don Quixote de la Mancha, fué sicmpre de apacible condicion, y de agradable trato, $y$ por esto no solo era bien querido de los de su casa, sino de todos quantos le conocian. Entró el escribano con los demas, $y$ despues de haber hecho la cabeza del testamen-
PARTE TI. CAPÍTULO LXXIT.

to , y ordcnado su alma Don Quixote, con todas aque1 las circunstancias christianas que se requieren, 1legando á las mandas, dixo: iren es mi voluntad, que de ciertos dineros, que Suncho Panza, á quien en mi locura hice mi escudero, tiene, que porque ha habido entre él y mí cicrtas cucintas, $y$ dares $y$ tomares, quicro que no se le haga cargo dellos, ni se le pida cuenta alguna, sino que si sobrare alguno, despues de haberse pagado de lo que le debo, el restante sea suro, que serí bien poco, y buen provecho le haga: y si como estando yo loco, fuí parte para darle el Gobierno de la Ínsula, pudiera agora, estando cucrdo, darle el de un Reyno, se le dicra, porque la sencillez de su condicion y fidelidad de su trato lo merece : y rolviéndose á Sancho, le dixo: perdóname, amigo, de la ocasion que te he dado de parecer loco como yo , baciéndote caer en el error en que yo he caido, de que hubo, $y$ hay caballeros andantes en el mundo. ¡Ay! respondió Sincho, llurando, no se muera vuesa merced, señor mio, sino tome mi consejo, y viva muchos años, porque la mayor locura, que puede hacer un hombre en esta vida, es texarse morir sin mas, ni mas, sin que nadie le mate, ni otras manos le acaben, que las de la melancolía. Mire no sea perezoso, sino levántese desa cama, y vámonos al campo, vestidos de pastores, como tencmos concertado, quizá tras de alguna mata hallarémos á la Scñora Doña Dulcinea desencantada, que no haya mas que ver. Si es que se muere de pesar de verse vencido, écheme á mí la culpa, diciendo que por haber yo cinchado mal á Rocinante, le derribáron: quanto mas, que vucsa merced habrá visto en sus libros de caballerías ser cosa ordinaria derribarse unos caballeros á Tom. $\mathrm{N}$ 
otros, y el que es vencido hoy, ser vencedor mañana. Así es, dixo Sunson, y el buen Sancho Panza está muy en la verdad destos casos. Señores, dixo Don Quixote, vámonos poco á poco, pues ya en los nidos de antaño, no hay páxaros ogaño: yo fuí loco, y ya soy cuerdo, fuí Don Quixote de la Mancha, y soy agora, como he dicho, Alonso Quixano el Bucno: pueda con vucsas mercedes mi arrepentimiento y mi verdad volverme á la estimacion que de mí se tenia, y prosiga adelante el seinor escribano. Iten mando toda mi hacienda á puerta cerrada á Antonia Quixana mi Sobrina, que está presente, habiendo sacado primero de lo mas bien parado della lo que fuere menester para cumplir las mandas que dexo hechas, y la primera satisfacion que se haga, quiero que sea pagar el salario que debo, del tiempo que mi Ama me ha servido, y mas veinte ducados para un vestido. Dexo por mis albaceas al señor Cura y al señor Bachiller Sanson Carrasco, que están presentes. Iten es mi voluntad que si Antonia Quixana mi Sobrina quisiere casarse, se case con hombre de quien primcro se haya hecho informacion que no sabe que cosa sean libros de caballerías : y en caso que se averiguare que lo sabe, y con todo eso mi Sobrina quisierc casarse con él, y se casare, pierda todo lo que le he mandado, lo qual puedan mis albaceas distribuir en obras pias á su voluntad. Iten suplico á los dichos señores mis albaceas, que si la buena suerte les truxere á conocer al autor, que dicen que compuso una historia que and a por ahi con el título de $S e$. gunda parte de las hazañas de Don Quixote de la Mancha, de mi parte le pidan, quan encarccidamente ser pueda, perdone la ocasion que sin yo pensarlo le dí, de

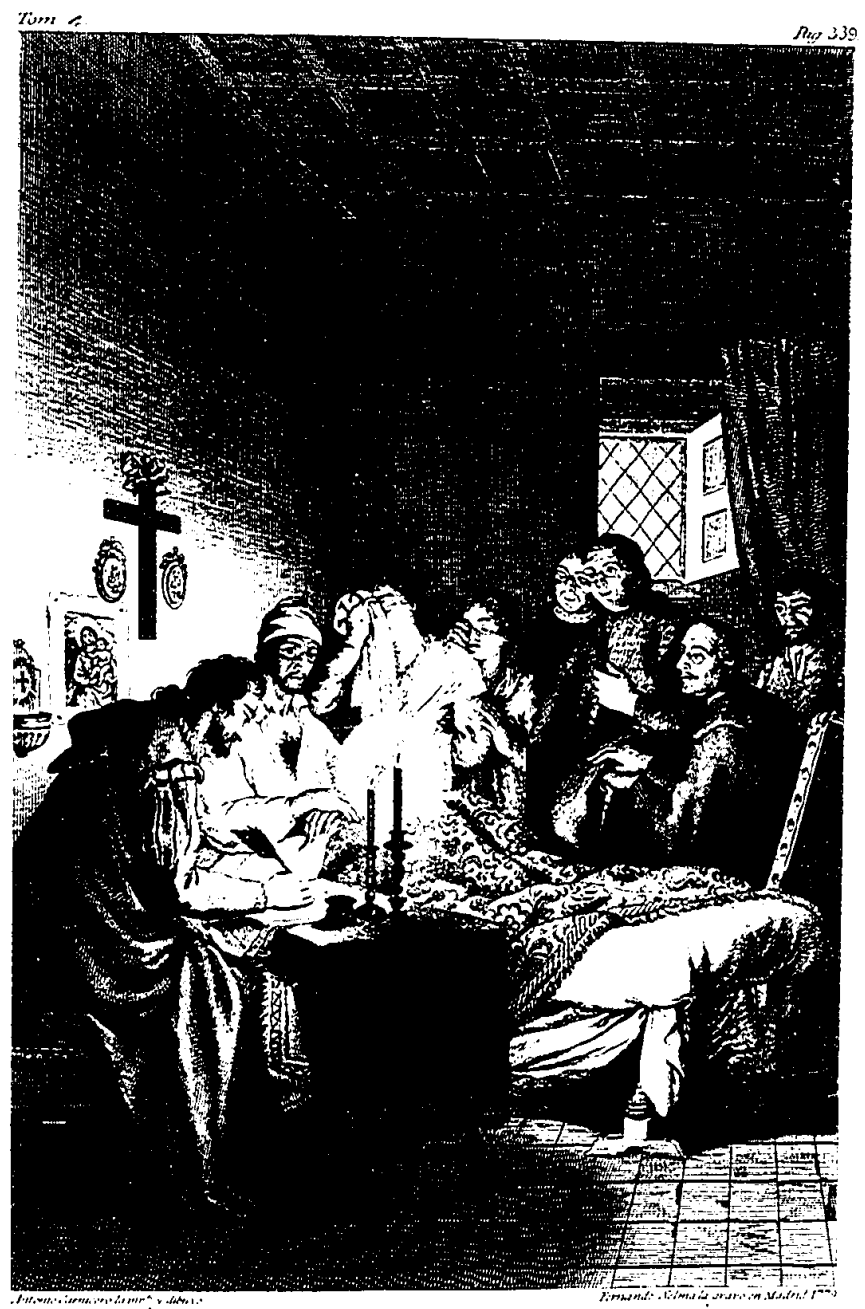


PARTEIT. CAPÍTULO IXXIV.

haber escrito tantos y tan grandes disparates, como en ella cscribe, porque parto desta vida con escrúpulo de haberle dado motivo para escribirios. Cerró con esto el testamento, y tomándole un desmayo, se tendió de largo á largo en la cama. Alborotáronse todos, y acudiéron á su remedio, y en tres dias que vivió despues deste, donde hizo el testamento, se desmayaba muy á menudo. Andaba la casa alborotada; pero con todo comia la Sobrina, brindaba el Ama, y se regocijaba Sancho l'anza, que esto del heredar algo, borra, ó templa en cl heredero la memoria de la pena, que es razon que dexe el muerto. En fin llegó el último de Don Quixote, despues de recebidos todos los Sacramentos, y despues de haber abominado con muchas y eficaces razones de los libros de caballerías. Hallóse el escribano presente, y dixo que nunca habia leido en ningun libro de caballerías, que algun caballero andante hubiese muerto en su lecho tan soscgadamente, y tan christiano como Don Quixote, el qual entre compasiones y lágrimas de los que allí se haliáron, dió su espíritu : quicro decir que se murió. Viencio lo qual el Cura, pidió al escribano le dicse por testimonio, como Alonso Quixano el Bueno, Ilamado comunmente Don Quixote de la Mancha, habia pasado desta presente vida, $y$ mucrto naturalmente, $y$ que el tal testimonio pedia para quitar la ocasion de que algun otro autor que Cide Hamete Benengeli le resucitasc falsamente, $y$ hiciese inacabables historias de sus hazañas. Este fin tuvo $\mathrm{cl} \mathrm{rN}-$ GENIOSO HIDALGO DE LA MANCHA, cuyo Lugar no quiso poner Cide Hamete puntualmente, por dexar que todas las Villas y Lugares de la Mancha contendiesen cntre sí, por ahijárscle, y tenérscle por suyo, como том. 1 . 
340

DON QUIXOTE DE LA MANCIIA

contendiéron las sicte Ciudades de Grecia por Homero. Déxanse de poner aquí los llantos de Sancho, Sobrina y Ama de Don Quixote, los nuevos epitafios de su sepultura, aunque Sanson Carrasco lc puso estc:

Yace aqui el hidalgo fuerte,

que á tanto cxtremo llegó

dc valiente, que se advierte,

que la mucrte no triunfo

de su vida con su mucrto.

Tuvo á todo el mundo en poco,

fuc el espantajo y el coco

del mundo, cin tal coyuntura,

gue acreditó su ventura,

morir cuerdo, $y$ vivir loco.

$\mathrm{Y}$ el prudentísimo Cide Hamete dixo á su pluma : aquí quedarás colgada desta espetera, y deste hilo de alambre, ni sé si bien cortada, ó mal rajada, péñola mia, adonde vivirús luengos siglos, si presuntuosos y malandrincs historiadores no te descuclgan para profanarte. Pero ántes que á ti lleguen, les puedes advertir, $y$ decirles en el mejor modo que pudicres:

\section{Tate, tate, folloncicos, \\ de ninguno sea tocada}

porque esta empresa, buen Rey,

para mi estaba guatdada.

Para mi sola nació Don Quixote, y yo para él : él supo obrar, y yo escribir, solos los dos somos para en uno, á despecho y pesar del escritor fingido y tordesillesco, que se atrevió ó se ha de atrever á cscribir con pluma de abestruz grosera y mal delinada las hazańas de mi valeroso caballero, porque no es carga de sus hombros,
PARTIII. CAPITULOLXXIV. $34 \mathrm{r}$ ni asunto de su resfriado ingenio, á quien advertirás, si acaso llegas á conocerle, que dexe reposar en la sepultura los cansados y ya podridos husesos de Don Quixore, $y$ no le quicra llevar contra todos los fuens de mote, $y$ no le quicra llevar contra todos los fueros de la muerte á Cartilla la Vicja, haciéndole salir de la fuesa, donde real y verdaderamente yace tendido de lares a dargo imposibilitado de hacer tercera jornada y salida nueva: que para hacer burla de tantas como hiciéron tantos an dantes caballeros, bastan las dos que él hizo tan á gusto y beneplícito de lus gentes á cuya noticia llexáron asto en estos, como en los cxtraños Reynus : y con esto cum plirás con tu christiana profesion, aconsejando bien a quicn mal te quicere, y yo quedaré satisfecho y ufano de haber sido el primero que gozó el fruto de sus escritos enteramente, como descaba, pues no ha sido otro mi deseo que poner en aborrecimiento de los hombes las fingidas y disparatadas historias de los libros de caballerías, que por las de mi verdadero Don Quixote van ya tropezando, y han de caer del todo sin ducta alguna. Vale.

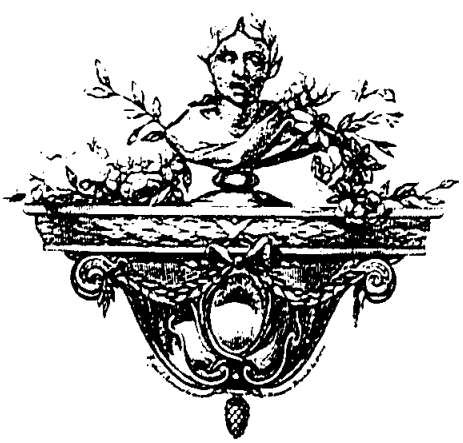




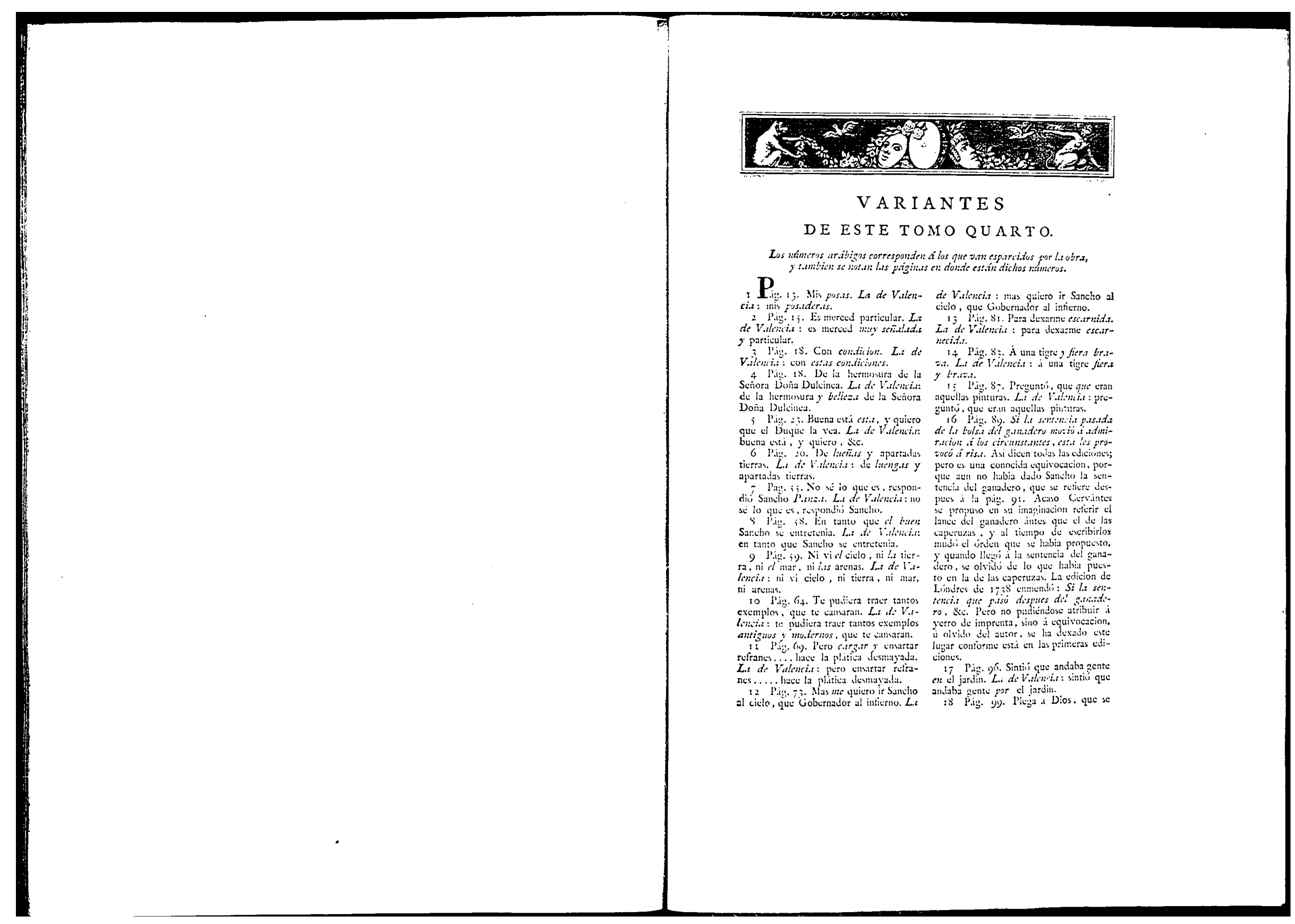


$3+4$

VARIANTES.

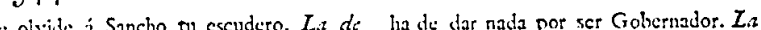

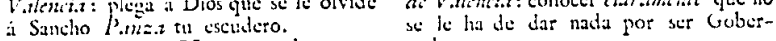
19) Pig. 10; Vos como buen selow buta Yizcilin.

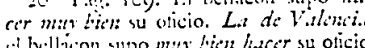

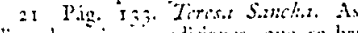

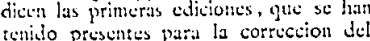

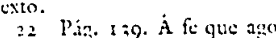

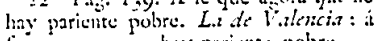
te que agora no hay pariente pobre: lerrnatores ine han de ir solas por los caminos. L.a de Vitlenciza : las hijas do

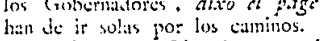

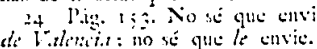

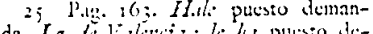
manda.

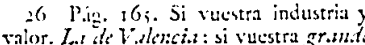

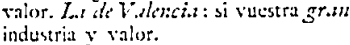

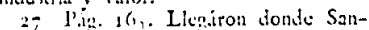

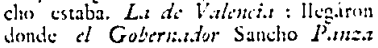

${ }_{28}$ C.ip. I-g. Digote . Ricote amigo,

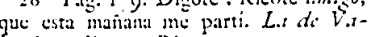
ianata me partí

29 Pije 179. Las rig̨uczas que so canan en los tilles Gobiernos. L.a dit Filemcint las riquezas que se ganan en to 1'ju. 186. Tu yoz oigo, San-

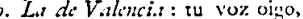
Sanclio amigo. 1 iag. A no depararme el Gielo \& mi señor Don Quixnte. L.7 $d$. an incógnito camino it mi seíor Dor

Quixote.
32 P.ig. $x$ sy. Conocer que no se 10

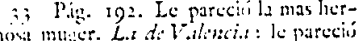

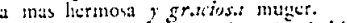

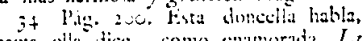

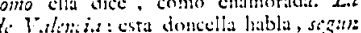
cilla dice, cono emimurata.

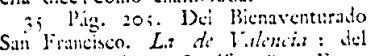
Bieniventurado y Sir.ifico San Fran-

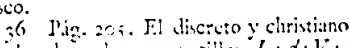

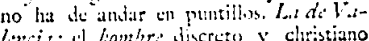

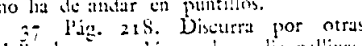

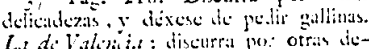

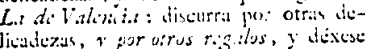
de pedit gallimas.

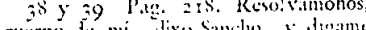

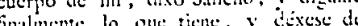
discurrimientos. Stior hucspist dixo al

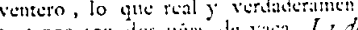
te tengo son

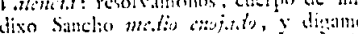

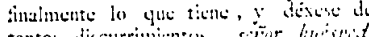

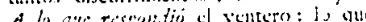
real y seriaderamente temo soa do whias de vaci. - Juri gor vita de sus

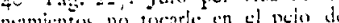

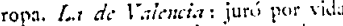

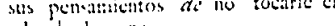
t1 Pig. 2.2. En una vimiara que

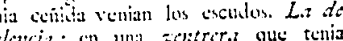

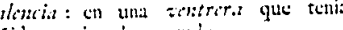

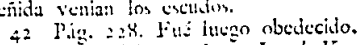

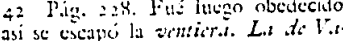

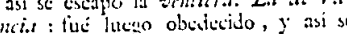
escapó la ien:erir.z.
43 Pig. $2: 4$. Sancho respontio que
VARIAXTES.

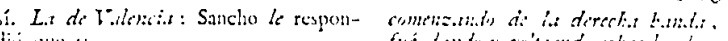

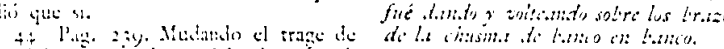

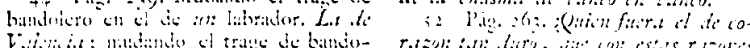

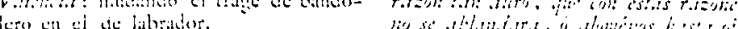

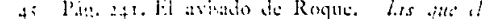

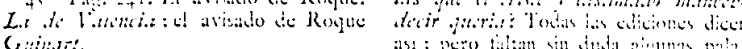

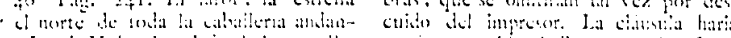

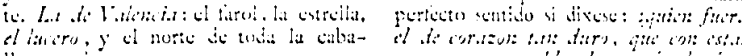

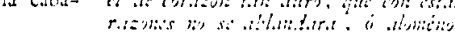

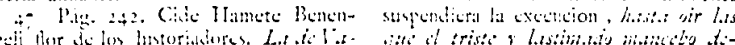

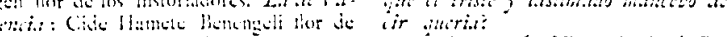

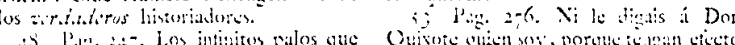

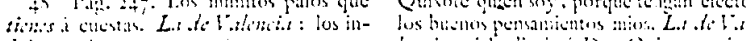

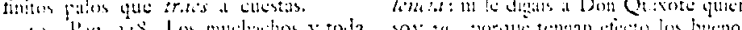
fo

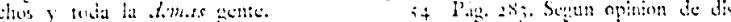

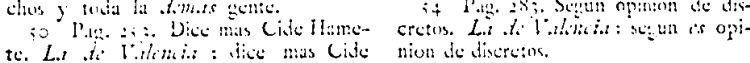

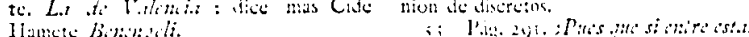

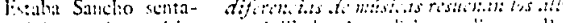

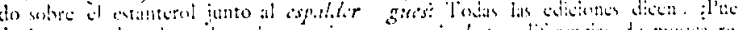

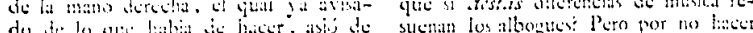

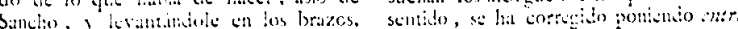

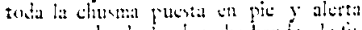

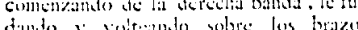

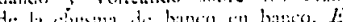

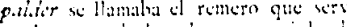

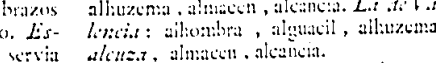

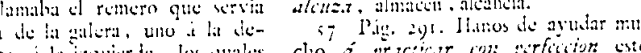

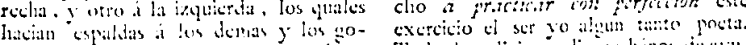

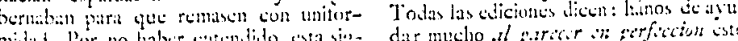

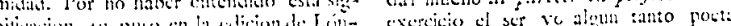

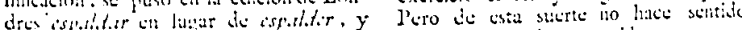

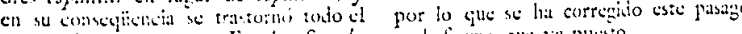

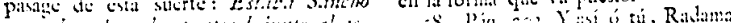

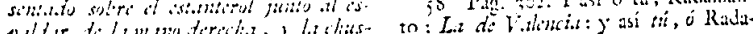

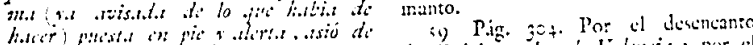

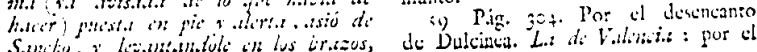
s.t. 


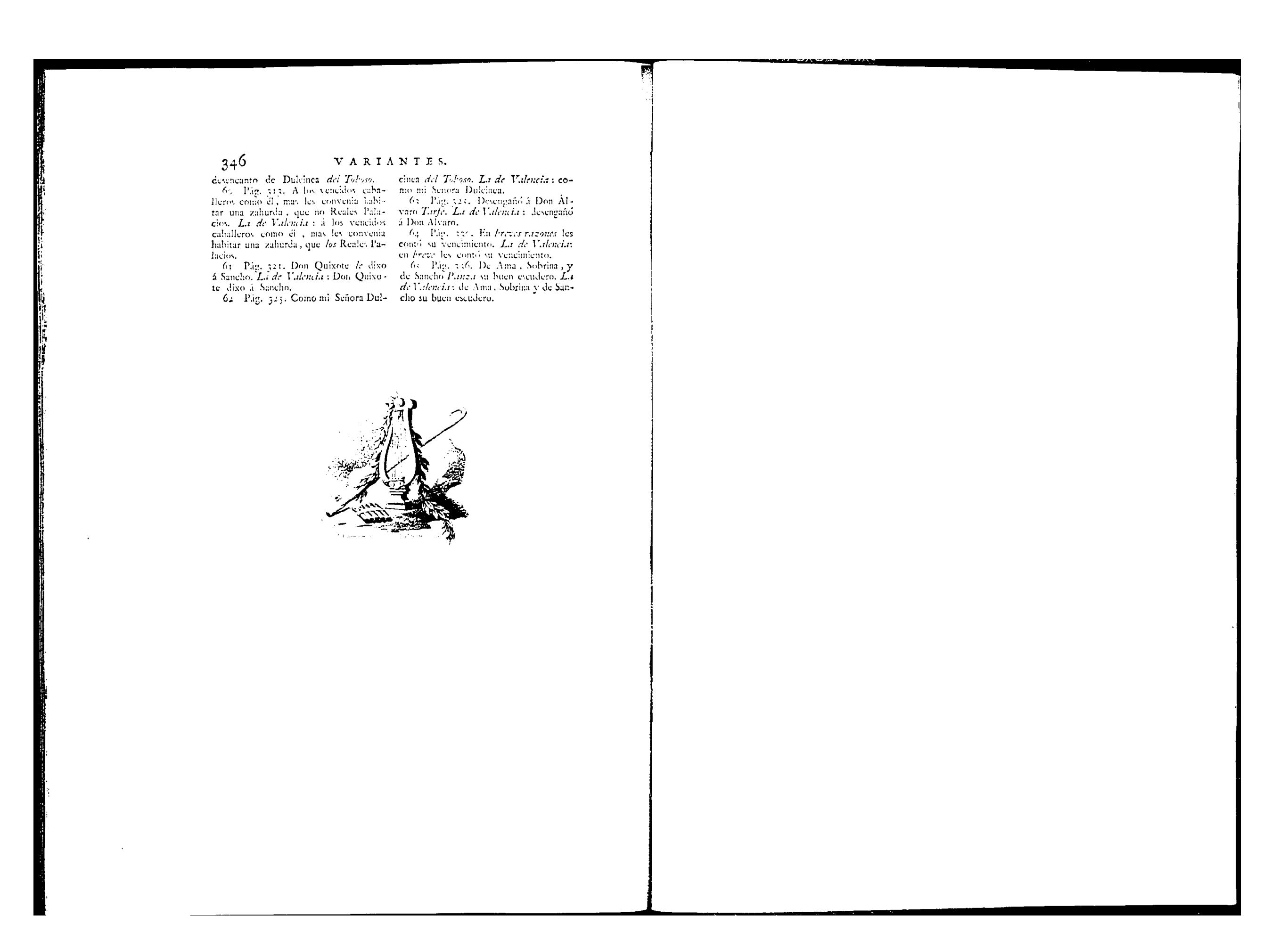

